\author{
UNIVERSIDADE DE SÃO PAULO \\ FACULDADE DE FILOSOFIA, LETRAS E CIÊNCIAS HUMANAS \\ DEPARTAMENTO DE LETRAS MODERNAS
}

PROGRAMA DE PÓS-GRADUAÇÃO EM ESTUDOS LINGUÍSTICOS E LITERÁRIOS EM INGLÊS

RENATO RAZZINO ERNICA

\title{
Ensaio semiótico sobre a narratividade nos jogos digitais
}


RENATO RAZZINO ERNICA

renatorazzino@usp.br

\section{Ensaio semiótico sobre a narratividade nos jogos digitais}

Dissertação apresentada ao Programa de PósGraduação em Estudos Linguísticos e Literários em Inglês do Departamento de Letras Modernas da Faculdade de Filosofia, Letras e Ciências Humanas da Universidade de São Paulo, para obtenção do título de Mestre em Letras.

Área de concentração: Estudos Linguísticos

Orientadora: Prof. ${ }^{a}$ Dr. ${ }^{a}$ Elizabeth Harkot de La Taille

São Paulo 
Nome: ERNICA, Renato Razzino

Título: Ensaio semiótico sobre a narratividade nos jogos digitais

Dissertação apresentada ao Programa de Pós-

Graduação em Estudos Linguísticos e Literários em Inglês do Departamento de Letras Modernas da Faculdade de Filosofia, Letras e Ciências Humanas da Universidade de São Paulo, para obtenção do título de Mestre em Letras.

Área de concentração: Estudos Linguísticos

Aprovado em: / 2014

Banca Examinadora

Julgamento:

Assinatura:

Julgamento:

Assinatura:

Julgamento: Assinatura: 
Para minha Mãe.

Para meu irmão Rodrigo.

Para minha madrinha Vera.

Para Naru, princesa da casa.

Para Elizabeth Harkot de La Taille, verdadeira mãe acadêmica.

Para Fernanda, Igor, Nicole, Vanessa, Shi, Renata, Renato, Caio, Juliana e Danilo, meus irmãos do coração.

A vocês, devo tanto que nem sei se devo: O próprio dever torna-se nada diante de tudo. 


\section{Agradecimentos}

À Faculdade de Filosofia, Letras e Ciências Humanas da Universidade de São Paulo, pela oportunidade da realização da Pós-Graduação.

À Coordenação de Aperfeiçoamento de Pessoal de Nível Superior (CAPES), pela bolsa concedida para a realização deste trabalho.

Aos membros da banca, pela leitura atenta e pelos comentários enriquecedores.

A Norma Discini, por toda a ajuda e carinho.

A Lynn Mario de Souza, pelas lições de vida.

Ao Ivã e ao Waldir, pelo apoio de sempre.

A Patrícia Coelho, por todo o carinho e ajuda.

A Edite, Júnior, Dina, Chico, Jurema e demais funcionários do Departamento de Letras Modernas tanto pelo tempo em que trabalhamos juntos quanto pelas inúmeras ajudas durante este percurso.

À Fátima e aos demais funcionários da Pós-Graduação da Faculdade de Filosofia, Letras e Ciências Humanas pela ajuda.

Ao querido Bigode e demais funcionários da Seção de Alunos de Graduação em Letras, sem os quais eu não teria terminado meu curso.

À Tia da Sociais/Letras, sempre alimentando todo mundo daqueles prédios.

Ao pessoal da Xerox, que sempre me atendeu bem. 
A Sabrina, Jéssica e Luís do CS: Games. Muito obrigado por tudo!

À galera da SAGA, Bruno, Danilo e Iara, por risadas, rolês e sushi.

This one in English: to everyone in Bliss, specially Keta, Ishi, Jirou, Seraven, Cora and Peach. You guys make my days blissful!

Aos amigos do GESUSP e da Semiótica, em especial Thiago, Saulo, Carol Tomasi, Eliane, Marcos, Ilca, Paula, Luis e Renata. Vocês são demais!

Ao pessoal da Aliança Francesa, pelas melhores noites de janeiro e fevereiro do mundo todo! E à minha turma atual, todos muito queridos, pelas manhãs de sábado desde março.

Aos meus professores da graduação: João Hansen, Adma Muhana, Annie Fernandes, Bruno Gomide, Adriano Scatolin, Marcelo Fernandes, Robson Cesila, José Antonio Pasta, Samuel Titan, Beatriz Gil, Giuliana Ragusa, Maria Sílvia Betti e Rosangela Sarteschi.

À minha irmãzinha de orientação Taís. À futura irmãzinha Carol.

Ao Císio, pelas inúmeras conversas.

Ao Rodrigo Moreira, filhote músico, escritor, roteirista e amigo.

Ao Ramão, por ser Ramão e isso basta!

À Renata Carneiro, pela amizade toda.

Ao Thiago Dias, que desde a escola me atormenta e é atormentado por mim.

Aos meus veteranos queridos que sempre me ajudaram: Matheus, Juliana, Edu, Fernando, Thiago e Myriam. Aos amigos Artur e Dani, por todo o carinho. 
Aos Dionisíacos: João, Samara, Jana, Rô, Gê, Caput, Elaine e Bruno. Minha jornada não seria a mesma sem vocês!

À minha família, toda ela maravilhosa.

À minha cunhada Suelen, pelo carinho de sempre.

À Tia Carmen e à Luzia, que ajudaram a me criar.

A meus irmãos, Alessandra e Fernando, que o destino conseguiu unir apesar de tudo. Também ao meu sobrinho João, verdadeiro presente.

Ao pessoal de São Carlos, todos eles, que fizeram minha infância muito feliz.

Ao meu padrinho Célio, por tanto que nem sei por onde começar.

Ao Décio e à Ivete, que sempre me acolheram bem em sua casa.

À Naru, que agora ronrona no sofá.

À Nicole e ao Caio, que revisaram este texto.

À minha orientadora, Elizabeth Harkot de La Taille, por tudo o que tem feito por mim.

A todos os meus irmãos do coração mencionados na dedicatória. Impossível esquecer de nenhum de vocês.

À minha mãedrinha Vera, sempre presente.

Ao meu irmão Rodrigo, que foi meu pai quando o nosso não quis mais ser.

À minha Mãe, que fez da minha vida a dela. 


\section{RESUMO}

ERNICA, Renato Razzino. Ensaio semiótico sobre a narratividade nos jogos digitais. 2014. 202 f. Dissertação (Mestrado) - Faculdade de Filosofia, Letras e Ciências Humanas, Universidade de São Paulo, 2014.

Usando o quadro teórico de diversas disciplinas, como a Semiótica Francesa (GREIMAS; FONTANILLE，1991; ZILBERBERG; FONTANILLE，2001; FONTANILLE，2011; ZILBERBERG, 2011), a Ludologia (SALEN; ZIMMERMAN, 2004; JUUL, 2005; RANHEL, 2009) e os Estudos de Mídia (MURRAY, 1995; SANTAELLA, 2004), esta dissertação tem por objetivo analisar a relação complexa entre a estrutura procedural (as regras e possibilidades) e o enredo no jogo Final Fantasy XIII; a organização narrativa da paixão "vingança" foi escolhida como objeto principal de nossa análise devido a sua estruturação complexa e sua popularidade na cultura ocidental. Essa relação concerne muito mais a uma experiência do que a uma contemplação, tendo em vista que o jogador não meramente observa o que personagens vivem e fazem, mas tem uma experiência de vivenciar de fato o conteúdo narrativo ao engajar-se em uma atividade estruturada de modo procedural; cada atributo procedural tem aspecto e ritmo particulares, os quais moldam a experiência e, por extensão, a história contada. Para conferir a maior clareza possível a esta análise, dividimos a dissertação em quatro capítulos, os quais abordam o problema sob pontos de vista diferentes - porém complementares. No primeiro, o conceito de "jogo" será discutido de modo a evitar especulação, senso comum e interpretação errônea das ideias aqui presentes; com a ajuda da Semiótica Francesa, no segundo capítulo analisaremos mais profundamente os resultados do Capítulo 1, e, ao fazê-lo, chegaremos a uma definição Semiótica do ato de jogar; o terceiro capítulo será dedicado a uma visão geral da relação complexa entre enredo e jogo - títulos como Super Metroid, Resident Evil e Silent Hill serão comparados; por fim, no Capítulo 4 usaremos os resultados obtidos nos capítulos anteriores para analisar Final Fantasy XIII e sua organização da vingança.

Palavras-chave: Semiótica Francesa. Jogos Digitais. Narrativa. 


\begin{abstract}
ERNICA, Renato Razzino. Ensaio semiótico sobre a narratividade nos jogos digitais. 2014. 202 f. Thesis (Master's) - Faculdade de Filosofia, Letras e Ciências Humanas, Universidade de São Paulo, 2014.
\end{abstract}

Based on the theoretical framework of a number of disciplines such as French Semiotics (GREIMAS; FONTANILLE， 1991; ZILBERBERG; FONTANILLE, 2001; FONTANILLE, 2011; ZILBERBERG. 2011), Ludology (SALEN; ZIMMERMAN, 2004; JUUL, 2005; RANHEL, 2009) and Media Studies (MURRAY, 1995; SANTAELLA, 2004), this thesis aims to analyze the complex relation between procedural structure (the rules and possibilities) and storytelling in the game Final Fantasy XIII; the narrative organization of the passion 'vengeance' has been chosen as the main subject of our analysis due to its complexity and popularity in Western culture. This relation is one of experience rather than portrayal, since the player does not simply learn about what the characters do and live, but has an actual experience of living the narrative content by engaging in a procedurally structured activity; each procedural feature has a particular aspect and rhythm which shapes the experience and, by extension, the story itself. To make this analysis as clear as possible, this thesis has been divided in four chapters, each tackling the problem from different - but complementary - angles. In the first one, the concept of 'game' will be discussed to avoid common sense speculation and misinterpreting of the ideas presented herein; with the aid of French Semiotics, in the second chapter we analyze the results of Chapter One more thoroughly and, by doing so, we arrive at a semiotic definition of gaming; the third chapter features an overview of the complex relation between storytelling and gaming - titles such as Super Metroid, Resident Evil and Silent Hill are compared therein; finally, in Chapter Four we use the results of the previous chapters to analyze Final Fantasy XIII and its organization of vengeance.

Keywords: French Semiotics. Video games. Narrative. 


\section{SUMÁRIO}

Introdução, 11

1. Perspectivas sobre o jogo digital, 14

1.1 Distopia e utopia: o estudo estético como busca da elevação do espírito, 16

1.2 Algumas considerações sobre o estudo ludológico do jogo digital, 22

2. A escolha epistemológica por trás do estudo semiótico do jogo, 44

2.1 Paixões, corpo e tensividade, 44

2.2 A visada semiótica no estudo de jogos, 58

2.3 O componente lúdico dos jogos digitais, 64

3. $\mathrm{O}$ jogo digital e sua complexidade narrativa, 69

3.1 Os problemas da noção tradicional de enredo no campo dos jogos digitais, 71

3.2 Tendências da proceduralidade progressiva em jogos digitais, 78

$3.3 \mathrm{O}$ gênero RPG, 105

4. Final Fantasy XIII e a estruturação da vingança como experiência, 121

4.1 Final Fantasy XIII: visão geral, 121

4.2 As condições da vingança, 132

4.3 A vingança como ideia fixa e negação da alteridade, 145

Considerações finais, 178

Referências bibliográficas, 180

Anexos, 182 


\section{Introdução}

O percurso de todo trabalho de pós-graduação na atualidade começa com um projeto. Uma promessa de passar de um estado a outro, do não saber ao saber e, como não poderia deixar de ser, à difusão desse mesmo saber adquirido. Nesse sentido, o pósgraduando atua como sujeito de sua própria performance e destinador de inúmeras outras que poderão surgir.

Embora tenha uma estrutura narrativa evidente, poucos diriam talvez que uma Dissertação conta uma história, cheia de percalços, anti-sujeitos e provas a cumprir. Fazemos parte desses poucos e esta Introdução tem por objetivo contar, mesmo que brevemente, a história deste texto.

O processo de pesquisa começou com uma abordagem bastante clara do jogo Final Fantasy XIII, a da Semiótica das Paixões, e tinha como hipótese principal a existência de uma relação narrativa entre Sujeito e Paixão na história contada por esse jogo. A Paixão representaria, discursivamente, o destinador dos sujeitos. Logicamente, o estudo teve início na definição semiótica do que se entende por uma Paixão e quais as possibilidades de tratamento dentro da teoria para o problema apontado. É nessa certeza que surgiu o primeiro obstáculo.

A inexistência de uma definição do termo dentro do Dicionário de Semiótica (GREIMAS; COURTÉS, 2012) obriga o pesquisador a voltar aos textos-base e tentar entender em qual front deve atacar. O reconhecimento das Paixões no discurso remonta à retórica aristotélica e, em linhas gerais, correspondem a "disposições afetivas nomeadas", diferenciadas por determinados traços, como fica claro nos trechos a seguir:

As emoções são as causas que fazem alterar os seres humanos e introduzem mudanças nos seus juízos, na medida em que elas comportam dor e prazer: tais são a ira, a compaixão, o medo e outras semelhantes, assim como as suas contrárias. Mas convém distinguir em cada uma delas três aspectos. Explico-me: em relação à ira, por exemplo, convém distinguir em que estado de espírito se acham os irascíveis, contra quem costumam irritar-se e em que circunstâncias; é que, se não se possui mais do que um ou dois destes aspectos, e não a sua totalidade, é impossível que haja alguém que inspire a ira. E o mesmo acontece com outras emoções (ARISTÓTELES, 2005, pp. 160-1)

O vexame é um obstáculo aos actos de vontade, não para daí se tirar proveito próprio, mas para impedir que não aproveite a outro. E como aquele que comete 
vexames não tira daí proveio pessoal, despreza-o, pois, como se torna evidente, nem sequer supõe que a pessoa vexada o possa prejudicar (é que, nesse caso, sentiria temor e não desdém), nem possa vir a obter dela alguma coisa que valha a pena (pois, nesse caso, pensaria em ser amigo dela) (Idem, p. 162, grifos nossos)

Essa perspectiva é bastante similar àquela presente em semiótica francesa; no entanto, se as definições podem ser comparadas, o objetivo do estudo retórico de uma paixão difere substancialmente da análise semiótica.

Segundo Bertrand (2003), o estudo semiótico das paixões visa a "construir uma semântica da dimensão patêmica nos discursos, isto é, considerar a paixão não naquilo em que ela afeta o ser efetivo dos sujeitos 'reais', mas enquanto efeito de sentido inscrito e codificado pela linguagem" (p. 357-8). Não se trata, portanto, de psicologizar os sujeitos de discurso ou verificar seus sentimentos íntimos, mas de observar quais os efeitos de sentido discursivos derivados das configurações passionais. O horizonte passional é

\begin{abstract}
o de uma subjetividade cujos estados individuais (estados de alma) são moldados pelas formas de expressão que a história cultural depositou na linguagem, dando lugar a configurações passionais mais ou menos estáveis, diferentemente categorizadas e valorizadas segundo as culturas e as épocas, e abrindo, assim, mais largamente a análise da paixão à dimensão histórica, social, estética e antropológica que a caracteriza. (Idem, p. 366)
\end{abstract}

O trecho de Zilberberg e Fontanille (2001) parece corroborar esse ponto de vista:

\footnotetext{
Uma paixão é antes de mais nada uma configuração discursiva, caracterizada ao mesmo tempo por suas propriedades sintáxicas - é um sintagma do discurso - e pela diversidade dos componentes que reúne: modalidade, aspectualidade, temporalidade etc. Com as paixões, a semiótica deve obter meios de tratar de conjuntos heterogêneos e de dar conta da sua coerência. (p. 297)
}

Uma paixão é, portanto, um estado ou conjunto de estados de alma cujo parecer, tendo como forma uma sequência, encontra-se estereotipado dentro de um universo cultural e socioletal, a ponto de receber uma denominação específica que permita sua identificação apesar das diversas variantes discursivas que possam existir. Depois de apreender uma noção geral a partir de textos introdutórios (ou talvez nem tanto), nosso próximo destino foi o livro Sémiotique des Passions (GREIMAS; FONTANILLE, 1991), dedicado inteiramente ao assunto. Essa leitura abriu caminho para o segundo obstáculo. 
Ao lidar com a paixão sob a perspectiva da continuidade entre os níveis do percurso gerativo, subordinando a semiótica da ação e da inteligibilidade ao sensível, Greimas e Fontanille estabeleceram um novo modo de fazer semiótica, focado na experiência de corpo. Esse ponto de vista teórico, levado adiante por teóricos como Zilberberg e Fontanille não nos permitia ignorar a instância de enunciação e, consequentemente, o jogo digital como linguagem.

A partir disso, nosso problema real tomou forma na seguinte constatação: não há, em semiótica francesa, grande número de trabalhos dedicados ao jogo digital, menos ainda considerando-os como linguagem autônoma, dotada de um modo próprio de significar. A solução encontrada foi a de sair momentaneamente da semiótica e buscar em outras searas teóricas as definições e conceitos que faltavam, para, depois, repensá-los com as categorias semióticas de que dispúnhamos. O impasse em que nos encontrávamos diante desse terceiro obstáculo deu origem a esta Dissertação.

Tendo contado brevemente a história deste texto, podemos afirmar que, longe de figurar como mera exigência do gênero, esta Introdução serve de fato como direcionamento de leitura. Cada capítulo atende a um problema resultante de nossa tomada de posição a respeito do objeto. No Capítulo 1, o leitor poderá encontrar uma apreciação geral dos estudos sobre jogos digitais, com destaque para aqueles que elaboraram uma definição clara do que é, afinal de contas, esse objeto. Os conceitos obtidos a partir daí receberão, no Capítulo 2, uma estruturação semiótica, focalizando seu aspecto tensivo. $\mathrm{O}$ atrito entre as ideias de narrativa, narratividade e enredo será trabalhado no Capítulo 3, posto que, quando consideramos o jogo digital, não é ponto pacífico a possibilidade harmônica entre o "contar histórias" e o "jogar". É apenas no Capítulo 4 que nossa proposta inicial retorna ao primeiro plano: armados com novos conceitos e posturas mais sólidas, analisaremos a estruturação lúdico-narrativa da Paixão "Vingança" no percurso das personagens Lightning e Hope de Final Fantasy XIII.

O caráter porventura incompleto do texto é fruto da tentativa de adequação à proposta: dar forma ao conhecimento arduamente construído acerca de um objeto metamórfico e novo, sobre o qual pouco se diz dentro dos muros da Universidade. Posto isso, singelamente convidamos o Leitor a fazer parte desta experiência, acolhendo criticamente o desenvolvimento teórico desta Dissertação, que não pretende dar a última palavra a respeito do assunto, mas iniciar, metaforicamente ao menos, um jogo proveitoso de produção de sentido. 


\section{Capítulo 1}

\section{Perspectivas sobre o jogo digital}

Todo trabalho científico começa pela definição de um objeto e pelo modo de apreendê-lo enquanto tal, isto é, uma hipótese de trabalho e uma linha teórica que determinarão um tipo de visada sobre um dado particular do mundo. Sendo assim, não basta dizer aqui que este trabalho será dedicado ao estudo de jogos digitais (video games), mas é necessário ir além e determinar o que exatamente se quer dizer com isso.

Os jogos digitais modificaram-se consideravelmente ao longo de sua existência, bastante curta se comparada aos demais tipos de jogos: começando como um experimento de laboratório no MIT, cujo intuito era meramente testar a capacidade de um novo tipo de computador, os jogos digitais passaram rapidamente a figurar em aparelhos especialmente projetados para esse fim, tanto em uso doméstico - na forma de consoles - quanto em público - game arcades (ou casas de máquina, como são popularmente conhecidas no Brasil). Com o passar dos anos, criaram-se consoles portáteis (Game Boy, PSP), os computadores foram popularizados e conectados em rede e a tecnologia digital produziu os mais diversos aparelhos (tablets, iPods, smartphones em geral) nos quais é possível instalar jogos, tornando possível jogar em rede de praticamente qualquer lugar do planeta.

De objeto-teste localizado em um laboratório universitário, os jogos digitais tornaram-se, em cerca de meio século, um fenômeno global que movimenta uma indústria multibilionária, a qual fica atrás, em termos de rentabilidade, apenas do ramo armamentício e automobilístico, como apontam Santaella e Feitoza (2009, p. x).

Devido a todos esses fatores, a apropriação do jogo digital como objeto de estudo pode ser feita sob diversas perspectivas, dentre as quais poderíamos citar três que nos parecem dominantes ou, pelo menos, mais óbvias: 1) se considerarmos sua recente integração às redes sociais, podemos pensar no jogo enquanto meio de sociabilização e no papel que ele desempenha na cibercultura, e, evidentemente, na vida cotidiana como um todo; 2) se partirmos de um ponto de vista econômico, abrimos espaço para sua definição enquanto produto passível de compra, venda e troca, inclusive por meios considerados ilícitos, como a pirataria, ou então, no caso dos jogos para redes sociais, para pensar a relativização de sua gratuidade, tendo em vista que para jogar é preciso permitir o acesso a 
diversas informações pessoais; e 3) se encararmos o objeto enquanto fenômeno de discurso, poderemos pensá-lo enquanto meio de comunicação, obra de arte ou fenômeno cultural, comparando-o à literatura, ao cinema, à música, seja por uma chave distópica, em que o jogo faria parte da "baixa cultura", um instrumento de alienação, seja utópica, em que ele seria a forma mais refinada e desenvolvida de veicular conteúdos (em uma hipótese de "fim da arte"), ou então em uma leitura que alguns chamariam de "realista" ou "neutra", que os considera como uma forma discursiva/artística/cultural entre outras, com propriedades específicas e definidoras, as quais precisam ser estudadas em profundidade. A perspectiva da ludologia poderia ser vinculada aos estudos discursivos de jogo na medida em que busca analisar o fenômeno como um fim em si mesmo, sem vinculá-lo necessariamente a um outro tipo de estudo.

Vale a pena salientar que as perspectivas aqui mencionadas não se excluem e não representam modelos de análise, posto que um trabalho como o de Juul (2005) lida com todos esses aspectos ao longo do texto. É a própria perspectiva crítica adotada que vai determinar qual o ponto principal abordado em cada estudo, sem que haja uma diminuição da importância dos demais: ignorar a complexidade inerente de qualquer produto cultural contemporâneo reduz consideravelmente o fenômeno e, consequentemente, a qualidade do estudo.

Nosso trabalho poderia ser vinculado à terceira "corrente" descrita no parágrafo anterior, na medida em que abordar em profundidade o aspecto comercial e/ou social do jogo em conjunto com sua especificidade discursiva foge do escopo de uma única dissertação de mestrado. Afirmar isso, no entanto, ainda é insuficiente para delimitar o objetivo, tendo em vista que a consideração do jogo como um fenômeno discursivo não indica uma postura única que precise ser adotada, tornando necessárias maiores considerações a respeito do que significa exatamente a visada discursiva aqui proposta. Este capítulo inicial será dedicado a comparar pontos de vista que consideramos próximos dessa linha de pensamento para, por fim, esclarecer o objetivo de nossa pesquisa e, evidentemente, o que se deve esperar desta dissertação. 


\subsection{Distopia e utopia: o estudo estético como busca da elevação do espírito}

Formas discursivas têm sido, ao longo da história, hostilizadas pelos mais variados motivos e culpabilizadas pelos problemas mais diversos: desde a apreciação da poesia feita por Platão no livro III de A República até imagens que circulam via Facebook, dizendo para todos lerem poemas em vez de passarem o dia na frente da TV ou do computador (ironicamente, notemos), há sempre um grupo de pessoas que poderá considerar determinada prática cultural, forma de arte e/ou comunicação como a responsável pela alienação ou degradação do homem. Da mesma maneira, não faltam exemplos de exaltação desta ou daquela forma, obra ou até mesmo de determinados autores, considerados essenciais para a formação humana - o chamado cânone. Diversos trabalhos da área de teoria literária demonstram esse desejo de olhar para trás e tentar mostrar o que é realmente bom, relevante ou necessário para entender determinada forma ou elevar o espírito; ou então aquilo que é responsável pelo estabelecimento de uma instituição ou movimento cultural dentro de um período. Menos comuns, talvez, sejam as posturas que consideram um tipo de discurso como o mais perfeito e bem acabado exemplo de expressão do espírito humano, mas há quem considere determinada forma como a forma entre formas, em uma perspectiva que desenha uma escala evolutiva e estabelece um final encarnado em uma obra ou meio expressivo ${ }^{1}$. Parece haver, no campo da discussão sobre estética e arte, a dominância de uma busca pela expressão mais elevada do espírito humano, livre das questões mercadológicas ou formalistas, consideradas degradantes. Cada objeto em foco seria, nessa chave de leitura, colocado sob um duro escrutínio cujo fim é determinar seu grau de benefício ou nocividade para um ideal de Homem, invariante em relação ao tempo e ao espaço ${ }^{2}$.

Fugiria do escopo de um capítulo listar exaustivamente todos os pontos de vista estéticos distópicos e utópicos, por mais importantes que possam ser, a respeito dos jogos digitais (seria necessário um estudo totalmente voltado para essa finalidade). Sendo assim, limitar-nos-emos, inicialmente, ao trabalho de Stallabrass (1996), que, baseado tanto em

\footnotetext{
1 Cf. http://www.histeria.blog.br/videogame-a-maior-das-artes/\#sthash.r6V8eHRh.dpbs (Acesso em $14 / 10 / 2014)$

${ }^{2}$ Essa perspectiva pode ser vislumbrada a partir da leitura de Adorno, T. Indústria Cultural e Sociedade. Seleção de textos de Jorge Mattos Brito de Almeida. Tradução de Juba Elisabeth Levy et al. São Paulo: Paz e Terra, 2009.
} 
Theodor Adorno quando em Walter Benjamin, sintetiza pontos críticos tanto favoráveis quanto desfavoráveis em relação aos produtos da chamada "cultura de massa" e chega a conclusões de bastante interesse para este estudo.

Stallabrass argumenta que um dos fatores mais importantes do jogo encontra-se na sua forte relação estrutural com a lógica mercantil liberal. O autor aponta, dentre os principais aspectos, três essenciais para a relação proposta: 1) os gráficos como forma de esconder a imaterialidade dos códigos de programação, responsáveis por uma equalização de todos os elementos do jogo; 2) a mecanização do corpo do jogador, que deve desumanizar-se para seguir os comandos rígidos do jogo; e 3) os elementos de recorrência das estruturas básicas de jogabilidade que, combinadas, formam uma progressão de enredo.

A reflexão sobre os gráficos tem seu ponto central no desvio da atenção para a estrutura do jogo, a qual teria relação com as bases da sociedade mercantil liberal. $\mathrm{O}$ "verniz" composto pelos diversos elementos do jogo cria uma materialidade imaterial, cuja função é criar uma ilusão de presença real, fazer com que algo concreto pareça estar ali, com uma "carne simulada" (STALLABRASS, 1996, pp. 87-88). Tais elementos, no entanto, seriam todos iguais no que diz respeito à sua "essência" composta de códigos programados: "like cast metal sculptures, virtual objects are hollow - code, like air, fills their voids, and their surfaces are a reflective chrome. They are mirror images of undifferentiated, mass-produced consumer goods." (Ibidem, p. 90) A essência da produção em massa apareceria aqui coberta pelos elementos "decorativos" do design, que atualmente são bastante comuns, não só em jogos - nos quais vemos uma crescente tendência à modificação de elementos tais como aparência das personagens, customização de roupas e equipamentos etc. -, mas também na crescente busca pela personalização de itens eletrônicos (celulares, notebooks): capas, cases decorativos, adesivos e pingentes são artigos comuns, utilizados em larga escala por consumidores para "enfeitar" aparelhos comprados no varejo, torná-los mais pessoais - a ironia estaria no fato de que elementos de personalização também são produzidos em massa: o individual é, em última instância, controlado pelas possibilidades que o mercado oferece.

Essa crítica de Stallabrass encontra-se problematizada em Ernica (2014):

Embora essa leitura possa ser interessante enquanto alegoria, é importante ter em mente que a codificação é parte integrante de um computador que, para (re)produzir qualquer tipo de informação, faz uso de cadeias 
numéricas binárias. Tanto a textura, quanto a base de polígonos, o texto e os diversos elementos sonoros são processados pelo computador por meio de códigos, que não podem ser entendidos, portanto, como uma forma de esconder algo imaterial: trata-se da produção de uma obra ficcional, e, no caso dos jogos, códigos de programação são tão imateriais quanto palavras descrevendo uma cena ou uma camada de tinta que representa um lábio em um retrato do século XVIII - são os blocos de construção utilizados, não um meio de esconder ou falsificar o que quer que seja. $\mathrm{O}$ desaparecimento de elementos e a indiferenciação (dos "cadáveres") observados por Stallabrass decorrem da limitação tecnológica da época em que o texto foi escrito: tendo de ser processados em tempo real, elementos que não têm mais utilidade na mecânica do jogo - destroços, inimigos eliminados, etc. - são removidos ou transformados em texturas de baixa taxa de polígonos para que a memória da máquina seja utilizada em outros processos. (p. 56)

Não se trata de uma questão estética tal como normalmente entendida, mas de uma exigência do meio. Atualmente, há diversos jogos que invalidam as considerações de Stallabrass devido à evolução tecnológica (apontada por ele, inclusive) desde a produção de seu texto.

O segundo ponto apontado por Stallabrass (1996) é a desumanização do jogador, que, forçado a responder rapidamente aos desafios propostos no mundo virtual, aproximarse-ia da máquina:

Computer games force a mechanization of the body on their players in which their movements and the image of their alter-ego provide a physical and a simulated image of the self under capital, subject to fragmentation, reification and the play of allegory. (p. 89)

Jogar bem é simular as qualidades da máquina (p. 90), criar uma nova relação com o próprio corpo, que agora está no limiar entre a realidade material e o virtual.

Esta visão nos parece bastante coerente, sobretudo se considerarmos toda a cultura envolvida em torno de jogos online, que ocupam boa parte da vida das pessoas e possibilitam relações interpessoais (por vezes problemáticas ${ }^{3}$ ): o contato com os avatares media a relação, no limiar entre real e simulado, entre indivíduos - ou melhor, simulacros complexos de indivíduos. Além disso, há o reconhecimento crescente de alguns jogos como $e$-sports ${ }^{4}$, criando uma relação ludo-corporal bastante complexa que será trabalhada em maior profundidade no Capítulo 2.

\footnotetext{
${ }^{3}$ A série de humor The Guild, disponível no Youtube, trata do tema.

4 Cf. http://www.techtudo.com.br/noticias/noticia/2013/07/league-of-legends-e-reconhecido-como-esportepelos-estados-unidos.html (acesso em 14/10/2014)
} 
Por fim, a projeção do tempo no espaço é um traço importante nos jogos: a progressão do enredo é feita por meio da exploração tanto do espaço quanto das possibilidades combinatórias dos elementos estruturais que jazem sob a camada gráfica. As combinatórias, no entanto, não são construídas ao acaso, pois tudo já se encontra programado:

While the linear unfolding of the plot as actually played is halting and uncertain, with many a wrong turn taken or target missed, the hierarchical structure of the game in virtual space is fixed from the start. (Ibidem, p. 91)

Além disso, Stallabrass aponta:

A striking feature of these games is their compression of time, both in the world of play, where moments separating action are dramatically foreshortened, and in the real world of the players, who re-emerge to discover that more hours have elapsed than they thought possible. (Grifos nossos, p. 92)

A noção de jogo digital como lugar de limiar aparece nessa característica de modo bastante evidente. A compressão do tempo dentro do jogo por meio de sua subordinação ao espaço afeta a percepção do real, e os modos como o jogador entra em contato com os elementos do jogo são muitas vezes organizados de modo a evitar que se pare de jogar:

In the arcade game there is no time for suspense and it is unprofitable to kill off the player with a single bullet. Enemies must advance and die in hordes, but for the player nothing can be irrevocable. Here ideology and marketing have arrived at a particularly felicitous marriage. (p. 94)

Tudo seria feito para alargar o tempo de jogo, mas diminuir a sensação de que o tempo passa fora do virtual. Além disso, é preciso dar múltiplas chances ao jogador, que, utopicamente, consegue avançar mesmo com todos os indícios de impossibilidade - é possível, no jogo, realizar o ideal do self-made man. No entanto, a ironia, para Stallabrass, reside no fato de que não é necessariamente o jogador que conquista a máquina:

The player's subordination of the game is achieved through the game's conquest of the player. Computer games perform simulated acts of reification in which slices of immaterial code act as living beings but are arranged and treated as objects. The brutal simplification of these digital figures is a register of objectification. (p. 97) 
Para o autor, o homem é, assim como fora do jogo, apenas mais uma mercadoria, com liberdade de ação restrita às imposições do mercado e do capital.

Stallabrass aponta também que as falhas de programação do jogo são brechas para a ação crítica:

\begin{abstract}
All of these points of fracture [bugs, glitches], of which hacking is the most extreme because it is deliberate, are marginal but radical, points at which the phantasmagoria is breached, and the structure of the game peeps through. (p. 98-99)
\end{abstract}

As falhas denunciam a estrutura que permanece escondida sob a camada gráfica, evidenciando o aspecto reificante do código. No entanto, tais falhas, segundo o autor, podem desaparecer à medida que a tecnologia progride e torna a ação fantasmagórica mais real. É interessante a reflexão sobre o avanço da forma de linguagem que vai, progressivamente, deixando os produtos anteriores obsoletos:

As the boundaries of illusion are pushed back, and player's expectations follow suit, games very quickly become obsolete. Yesterday's state-ofthe-art games are unplayable today since the act of imagination and involvement necessary is intimately tied to the progress of the technology at any particular moment. (p. 105)

Os jogadores de uma geração olham com estranhamento para os jogos das gerações passadas, pois lhes falta o comprometimento, a disposição necessária para tomar parte no ato imersivo de jogar. A velocidade com que a tecnologia avança e com que é reproduzida é inerente à forma expressiva dos jogos. Stallabrass não entra na discussão dos méritos artísticos do jogo em termos estéticos mais tradicionais, relacionando-se com Benjamin (1987), que tenta estabelecer critérios específicos para o tratamento do cinema enquanto meio expressivo distinto da arte de seu tempo. Os comentários sobre espaço e tempo, bem como a progressão tecnológica que modifica o modo como vemos o objeto, serão aprofundados no Capítulo 3.

Stallabrass (1996) termina seu texto apontando para uma distopia: segundo o autor, os jogos simulariam, sem crítica, um futuro de mecanização em que chacinas e genocídios serão considerados atos heróicos (p. 109). Seus argumentos, no entanto, falham ao colocar o jogo como algo necessariamente alienante e esvaziado de significado (crítico), revelando certa afinidade com algumas concepções de cultura de massa que consideram os objetos culturais contemporâneos como meros produtos, cujo único sentido crítico reside no fato 
de evidenciarem quão problemática a situação é, sem que possam, eles mesmos, produzirem crítica por meio do que veiculam - em suma, os jogos podem ser criticados, mas não são, em si, críticos. Esse viés de análise vai de encontro ao ponto de vista adotado neste trabalho, que parte do princípio de que qualquer produto cultural pode gerar leituras críticas, visto que o sentido não se encontra no objeto, mas nasce do ato produtor de sentido: o discurso.

É necessário salientar, ainda, que não se trata de inverter a postura de Stallabrass e afirmar que os jogos digitais não causam alienação ou que eles representam a maior expressão de nosso tempo por conjugar diversos aspectos da vida contemporânea, como a rápida progressão tecnológica, a interação social por meio da Internet, a predominância do audiovisual digital sobre o texto escrito e outros mais. Não acreditamos que seja possível sustentar, como alguns membros da dita "comunidade gamer" o fazem", que os jogos digitais superem as formas de arte tradicionais e não consideramos necessário entrar na discussão do estatuto artístico do jogo - ao menos não neste trabalho - para lidar com o objeto de um ponto de vista da semiótica francesa. A questão principal gira em torno de sua significação: é um dado que, sendo arte ou não, representando um objeto cultural benéfico ou pernicioso, o contato com um jogo digital produz sentido - caso contrário sequer seria alienante, pois a própria alienação é, na verdade, a adoção de uma visão de mundo considerada inadequada por quem vê a si mesmo como libertário ou progressista ${ }^{6}$. Porém, constatar que algo significa é, de acordo com o desenvolvimento teórico da semiótica francesa, afirmar o óbvio, tendo em vista que a mera percepção de um objeto por parte de um sujeito inserido no mundo produz significado. É preciso ir além e determinar $o$ tipo de significação própria aos jogos digitais que os distingue de outros objetos, como uma placa de sinalização de trânsito, um romance ou uma peça de vestuário. É preciso que os jogos digitais sejam encarados como objetos autônomos enquanto produtores de sentido e observar em que medida suas especificidades contribuem para o enriquecimento da teoria semiótica. É nessa discussão que se insere este trabalho.

Para empreender tal estudo, é necessário recorrer às pesquisas em ludologia e definir o que é um jogo, pois não há, em teoria semiótica, uma definição do que isso venha

\footnotetext{
${ }^{5} \mathrm{Cf}$. link presente na nota de rodapé número 1, com especial atenção para os comentários ao post do blog.

${ }^{6}$ A importância dada ao texto de Stallabrass baseia-se nos pontos suprassalientados que serão desenvolvidos em profundidade nos próximos capítulos.
} 
a $\operatorname{ser}^{7}$. Foge do escopo deste trabalho documentar todas as definições dadas ao objeto e compará-las historicamente; trabalharemos a seguir com os estudos de Salen e Zimmerman (2004), Juul (2005) e Ranhel (2009), observando qual o tipo de visada existente em cada um deles e discutindo seus ganhos e deficiências sob a luz da semiótica francesa.

\subsection{Algumas considerações sobre o estudo ludológico do jogo digital}

Lidar com o jogo digital de um ponto de vista ludológico diferencia-se da abordagem de Stallabrass, pois não há, a priori, uma preocupação com a relação crítica do jogo com os outros elementos da cultura e da vida humana. Isso não significa, no entanto, que os estudiosos ignorem a posição do jogo na sociedade, na teoria da arte e da cultura, seu componente mercadológico e sua possibilidade de servir como meio de interação social. Trata-se, como já dito no item anterior, de uma delimitação de território. Estando nosso trabalho inserido nessa perspectiva ludológica, mas havendo uma proposta de repensar o objeto com o auxílio da teoria semiótica de linha francesa, não nos interessa meramente observar os conceitos e ganhos da ludologia e sim problematizá-los de acordo com o horizonte do sentido, objeto de estudo da semiótica. Sendo assim, a dinâmica de estudo presente neste item será a de observar quais conceitos de teoria semiótica podem ser mobilizados para entender as definições e considerações ludológicas, e completar suas lacunas.

Começando pelo trabalho de Salen e Zimmerman (2004), vemos que a abordagem dada aos jogos é bastante ampla, passando por três esferas, a das regras, a do ato de jogar e a da cultura, em um contínuo no que concerne à expansão do ponto de vista adotado: enquanto no aspecto cultural (o último enfocado pelos autores) os jogos são vistos em sua relação com a sociedade - tanto no modo como são modificados por ela quanto no modo como eles a modificam -, no campo das regras, a estrutura dos jogos é colocada em evidência. No entanto, apesar de os três pontos abordados pelos autores serem imprescindíveis e complementares, sua definição de jogo parece dar primazia às duas primeiras esferas: "A game is a system in which players engage in an artificial conflict,

\footnotetext{
${ }^{7}$ Assim como não se define o que é literatura, música ou cinema. Não é do domínio da teoria este ou aquele objeto significante em particular, mas a significação enquanto objeto autônomo. Portanto, não é incomum ou incoerente que primeiro se façam incursões por outros campos teóricos de modo a buscar definições ou dados, sobretudo quando o objeto em foco não tem grande aceitação acadêmica e, consequentemente, não se dispõe de literatura copiosa sobre ele.
} 


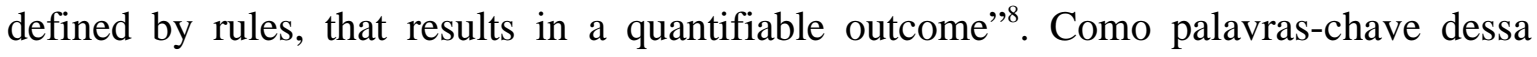
definição, podemos destacar as seguintes: system, engage(ment), conflict, rules e outcome.

A noção de jogo como um sistema artificial traz consigo implicações diversas. Em primeiro lugar, podemos, grosso modo, considerar sistemas como conjuntos de relações entre elementos que, por meio dessas mesmas relações, adquirem alguma função ou sentido dentro do sistema. Um conjunto de marcadores coloridos, por exemplo, pode ser sistematizado em uma empresa de modo a facilitar a compreensão por parte dos funcionários que os utilizam para desempenhar suas funções - marcações em laranja podem indicar que os resultados são insatisfatórios enquanto marcações em rosa indicam que houve sucesso e vice-versa. Apontar que uma prática social qualquer pode ser sistematizada é importante na medida em que a questão da arbitrariedade de um sistema se evidencia quando transformamos o substantivo sistema no verbo sistematizar, que evidentemente pressupõe um agente, um operador que vai criar as teias de relações entre os elementos escolhidos como parte do sistema. Mesmo que algo pareça sistemicamente natural, a ideia de naturalidade ou de obviedade é artificial na medida em que o operador é, como aponta Fontanille (2011, p. 4), sempre um corpo, sempre carne localizada no tempo e no espaço e, portanto, presa a um ponto de vista. ${ }^{9}$ Em jogos, a arbitrariedade é evidente, tendo em vista a possibilidade de utilização de um mesmo objeto em mais de um jogo sem que ele se comporte, necessariamente, de maneira igual em todos eles, o que evidencia que a natureza do objeto (seu formato, por exemplo) pode não interferir em seu papel no sistema.

Isto posto, o conceito de valor parece se adequar. De acordo com Greimas e Courtés (2012), a noção de valor é contemplada por campos diferentes do conhecimento, mas neste trabalho salientamos o modo como o conceito é trabalhado por Saussure. O verbete no dicionário de semiótica diz o seguinte:

2. É a F. de Saussure que cabe o mérito de haver introduzido o conceito de valor linguístico: constatando que o sentido não reside senão nas diferenças apreendidas entre as palavras, ele coloca o problema da significação em termos de valores relativos, ou seja, que se determinam uns em relação aos outros; (p. 526)

\footnotetext{
${ }^{8}$ Por se tratar de uma referência a partir da versão $e$-book, não há como indicar a página onde se encontra o trecho.

${ }^{9}$ Consideramos, neste trabalho, a ação de sistematizar também como produtora de sentido para o seu agente.
} 
A ideia de que o sentido existe porque há relações entre palavras, e não apenas na existência isolada de uma palavra, nos remete a duas noções importantes: a ideia de rede ou teia que pode servir para expressar graficamente um sistema, indicando que não há ponto no sistema que exista isolado sem importância no todo; e também sugere a interpretação, não evidente na definição de Saussure, de que os elementos de um sistema são organizados e não que se organizam per $s e^{10}$. É a questão da arbitrariedade mencionada acima que nos faz crer que os valores são atribuídos ao invés de existirem a priori. Essa ideia aparece reiterada neste ponto, para falar de valor atribuído em oposição a valor intrínseco, pois o jogo é constituído de uma atribuição arbitrária de valores a objetos, ou seja, a criação de uma relação não intrínseca entre elementos diversos. Uma vez atribuídos, os valores tendem a ser mantidos por uma determinada comunidade, o que não significa que não possam ser modificados de certa maneira ou ajustados de modo a adequar-se à situação específica de sua utilização: o Futebol não perde sua identidade ${ }^{11}$ quando tem determinadas regras alteradas para que a experiência de jogo seja mais proveitosa.

O segundo ponto da definição, a ideia de engajamento em conflito, é para nós importante na medida em que nos remete ao esquema narrativo canônico do percurso gerativo do sentido. Pensar na polêmica como base de uma narrativa, considerando que sempre haverá valores em trânsito, não é estranho à semiótica; com efeito, a mudança de um estado a outro, isto é, a transformação, é justamente o que move o sujeito do fazer: querer $^{12}$ passar de um estado de disjunção com algum objeto-valor para um estado de conjunção com esse objeto-valor (ou vice-versa) é o requisito mínimo para que haja uma narrativa. Um sujeito que se encontra realizado em seu estado atual não desenvolverá a performance ${ }^{13}$.

As características do conflito são sua definição por regras e seu resultado quantificável, sem os quais não podemos compreender um jogo como tal. As regras dizem

\footnotetext{
${ }^{10}$ Da mesma forma que a junção entre os planos da linguagem é tratada por Fontanille (2011) como algo sediado no corpo, a atribuição de valores ocorre no ato semiótico: a inteligibilidade dos dados sensíveis surge a partir da discretização geradora de valores e categorias, como apontam Greimas e Fontanille (1991).

${ }^{11} \mathrm{O}$ conceito de identidade utilizado neste trabalho baseia-se na filosofia de Ricoeur (2006). Grosso modo, trata-se de uma tensão entre a permanência, a inovação, e a relação com o outro. Este estudo será melhor desenvolvido no Capítulo 4.

${ }^{12}$ Para fins de economia no texto, consideraremos o dever como a adoção do querer do destinador.

${ }^{13}$ Vale ressaltar que essa consideração estrutural concerne ao nível narrativo, no qual as categorias de tempo, pessoa e espaço encontram-se reduzidas a operações lógicas e os valores e actantes não se encontram revestidos por temas e figuras. Essa "roupagem" ocorre apenas no nível discursivo. Sendo assim, uma narrativa de caráter existencialista, por exemplo, em que aparentemente nada ocorre e as personagens não agem de modo significativo, ainda tem como base um conflito de valores, figurativizado enquanto conflito interno ou colocado num horizonte de expectativa que nunca ocorre.
} 
respeito aos valores do sistema, os quais indicam não só o que cada elemento significa na rede, mas também as condições para que a performance seja considerada válida, ou seja, para que o resultado possa adquirir valor dentro daquele sistema específico, é preciso que ele siga as diretrizes. Salen e Zimmerman (2004) apontam que uma das características do jogo de golfe é o modo como ele obriga o jogador a realizar a tarefa contra a lógica do menor esforço: para colocar a bolinha dentro do buraco, o mais óbvio, de acordo com eles, seria pegá-la com a mão e andar até ele; no entanto, as regras do jogo de golfe não permitem que isso seja feito e, caso seja, o resultado não poderá ser computado. Colocando esta reflexão dentro dos termos aqui propostos, podemos pensar que o elemento "mão" não adquire valor quando colocado em relação com os elementos "bola" e "buraco" - é preciso que isso seja feito com o taco, caso contrário, a ação será inválida.

É importante salientar que colocar a bola no buraco usando as mãos é uma ação que, empiricamente, pode ocorrer, mas não é considerada como pertencente ao jogo de golfe na medida em que não tem valor no sistema. Agir desse modo pode ter significados diferentes, por exemplo: uma brincadeira divertida, caso os jogadores sejam amigos de longa data em um domingo à tarde; ou conduta antidesportiva, caso a partida em questão seja de campeonato. O importante aqui é ressaltar que em ambos os casos a performance é sancionada negativamente, classificada como não pertencente ao jogo tendo em vista que não é, nem parece ser, uma performance prevista nas redes de valores do sistema.

Isso parece ser verdadeiro para vários dos tipos de jogadores descritos por Salen e Zimmerman (2004), dentre os quais podemos citar aquele que trapaceia de modo não explícito - alterar o código de um jogo online, por exemplo, faz com que a performance pareça adequada sem o ser - e o que joga a sério demais - utilizar jogadas complexas em uma partida de damas contra uma criança cria um conflito de regras, em que o adulto se engaja em uma atividade estruturada pelo sistema "damas", enquanto se espera que ele faça uso de um sistema mais simples (“damas para crianças”), em que determinadas jogadas que podem emergir do conjunto de valores sistematizados estão previstas no sistema como não-possíveis.

Vale a pena deter-se no conceito de emergência. Segundo Salen e Zimmerman, jogos são sistemas emergentes, isto é, que possuem um determinado número de elementos passíveis de recombinação, formando padrões não previstos diretamente no sistema. $\mathrm{O}$ Mate Pastor no jogo de xadrez serve como exemplo de uma jogada famosa a ponto de aparecer na Wikipedia em diversas línguas. A entrada em português diz o seguinte: 
Mate Pastor é um tipo de xeque-mate básico efetuado pelas [peças] brancas durante a abertura, que segue a ideia de atacar o peão que se encontra na casa $\mathrm{f} 7$, e que é defendido apenas pelo rei, de acordo com os seguintes lances: 1. e4 e5; 2. Dh5 Cc6; 3. Bc4 Cf6??; 4.Dxf7\#.

O Mate Pastor não se encontra diretamente inscrito no sistema, mas é um padrão que emerge a partir dos valores que dele surgem. Padrões emergem, portanto, a partir da enunciação, isto é, derivam da prática de jogar, de se engajar nessa atividade. A emergência pode ser proposital e fruto do estudo atento dos valores do sistema, indicando, assim, algo intrínseco a essa forma discursiva e que reside em reconhecer a presença de um conjunto de valores na virtualidade, os quais se atualizam e se realizam por meio da enunciação.

Partimos de Zilberberg e Fontanille (2001, pp. 123-34) nessa reflexão. Os autores definem a presença não como o simples oposto dicotômico da ausência, mas como uma relação complexa entre as categorias real(izado) e virtual(izado), contrárias uma à outra, complementadas pelas subcategorias atual(izado) e potencial(izado $)^{14}$. No caso de uma partida de um jogo qualquer (como o Futebol, por exemplo), sabemos que o evento perceptível é um enunciado em devir, proveniente de uma enunciação que realiza um conjunto de regras existentes na virtualidade. Isto equivale a dizer que, enquanto modus operandi, o Futebol é apenas latente (apenas forma) e ganha substância quando praticado. ${ }^{15}$ Nesse sentido, o criador de jogos atua como um destinador, alguém que transmite os valores ao sujeito para que ocorra a performance. $\mathrm{O}$ esquema narrativo canônico do percurso gerativo do sentido aparece, portanto, representado em sua totalidade.

Havendo destinador e destinatário, no âmbito da comunicação de valores, e sujeito e objeto-valor em conflito, no âmbito da transformação - no mínimo há a busca pela conjunção com a vitória, em oposição a uma noção disfórica de derrota no nível profundo -, parece-nos razoável pressupor a existência de anti-sujeitos já que, de acordo com a definição de jogo, é preciso haver conflito pelo objeto. Além disso, o exemplo dos jogadores descritos acima (os que "estragam" a experiência) nos permite pensar no conflito

\footnotetext{
${ }^{14}$ A criação das regras de um jogo potencializa a existência desse jogo, na medida que introduz na virtualidade um conjunto de procedimentos que podem ser atualizados por participantes que realizarão esse jogo.

${ }^{15}$ É um processo análogo à colocação em discurso das línguas naturais. A ideia de que cada enunciado realizado está virtualmente contido nas possibilidades estruturais da língua é similar à constatação de que cada partida de Futebol está contida no conjunto de regras do esporte.
} 
entre destinadores: percursos diferentes concorrem durante a partida e o sujeito fica disjunto de seu objeto de valor na medida em que a performance de alguns anti-sujeitos, ao ser baseada nos valores do anti-destinador, invalida o evento de jogo.

Mencionamos acima a possibilidade de "aliviar" o jogo de Damas quando o oponente é uma criança, o que, evidentemente, modifica suas regras e instaura um outro destinador além daquele pressuposto pela existência do sistema. Esse segundo destinador, no entanto, não se constitui como anti-destinador na medida em que seu objetivo é a manutenção do sistema devido a algum conflito entre as regras específicas do jogo e as diretrizes mais gerais da atividade lúdica (ela precisa ser competitiva, precisa ser divertida etc.): uma criança não pode competir contra um adulto caso as regras tenham um nível de dificuldade elevado. Outro exemplo é o jogo Imagem \& Ação, produzido no Brasil pela empresa Grow, em que os jogadores devem desenvolver por meio de desenhos o que está escrito em cartas. Apesar de as regras oficiais indicarem a ação de desenhar como o meio adequado de jogo, há diversas variantes populares que incluem a mímica como elemento passível de ser combinado com o desenho ou até mesmo de substituí-lo por completo sobretudo quando não há papel e caneta disponíveis. O outro destinador, no caso, é um adjuvante, representado pelos jogadores que modificam os valores do sistema de modo a terem uma experiência lúdica mais satisfatória ou adequada à conjuntura - é a própria enunciação que instaura esse destinador.

Essas ocorrências levam Ranhel (2009, p. 21) a levantar a polêmica, já existente entre os ludologistas, de que o jogo é algo indefinível, posto que o conjunto de valores estabelecido pelo designer pode não ter força o bastante para se impor totalmente. A ideia de que sejam agrupadas sob o rótulo "Xadrez" todas as variantes possíveis de jogo tornaria, segundo Ranhel, o jogo impossível de ser definido.

Esse fator cultural dos jogos a que alude Ranhel é reconhecido por Salen e Zimmerman (2004) como elemento inseparável das regras e do ato de jogar, e demonstra, em nossa opinião, não a impossibilidade de definição do que vem a ser um jogo, mas justamente o contrário: tendo em vista que todas essas variantes são praticadas e reconhecidas como uma atividade lúdica, é razoável pressupor que nenhuma delas fuja à definição de jogo dada por Salen e Zimmerman, ou seja, todas as modalidades são, ao fim e ao cabo, um sistema de valores que é assumido por sujeitos a fim de gerar um conflito 
com resultado quantificável ${ }^{16}$. Dizendo com outras palavras, a modificação do sistema cristalizado pelo criador do jogo gera um sistema análogo que é, também ele, reconhecido como jogo.

É a partir dessa constatação que surge a hipótese norteadora deste trabalho: para além do modo como os jogos se modificam ao longo da história em seus meios de expressão (seja em tabuleiro, por meio de ações corporais em espaços cotidianos ou em design digital), suas plataformas e a relação disso tudo com as mudanças nas outras esferas da vida humana, existe algo comum a todos os jogos, um modo específico de existência que nos permite classificar dentro de uma mesma categoria fenômenos tão distintos em sua expressão e posição na sociedade como as práticas poéticas palacianas dos séculos XII, XIII e XIV; os jogos de carta e tabuleiro; esportes como futebol e ginástica artística; e, por fim, Final Fantasy XIII (que requer um console de última geração e uma TV) e Angry Birds (que pode ser jogado em qualquer smartphone, tablet ou navegador de internet). É importante ressaltar que esse "algo comum" não se pretende universal e imutável, na medida em que o conceito de jogo, bem como os próprios meios de percepção do mundo real, são construídos discursivamente, ou seja, variam no espaço e no tempo. Nossa hipótese baseia-se tão-somente na observação de padrões dentro do que se considera jogo na cultura ocidental e na constatação de que jogos são reconhecidos como tal por espectadores diversos mesmo quando sua estrutura de regras não é conhecida. Por exemplo, ao se deparar com um grupo jogando algo como Bocha no quintal de casa ou ao observar crianças jogando Taco na rua, um observador é capaz de reconhecer que há uma relação entre os elementos constitutivos do jogo (bolas e marcações no caso de Bocha; bolinha, tacos e pedras no caso de Taco) que ultrapassa sua função ou estado comuns. Outro exemplo, que pode ser resumido na imagem a seguir, retirada da página Velhos Tempos do Facebook:

\footnotetext{
${ }^{16}$ É preciso ressaltar que Ranhel, tendo publicado seu texto posteriormente, trabalha com mais definições de jogo além daquela postulada por Salen e Zimmerman (2004), sendo a principal delas a de Juul (2005), com a qual trabalharemos mais adiante.
} 


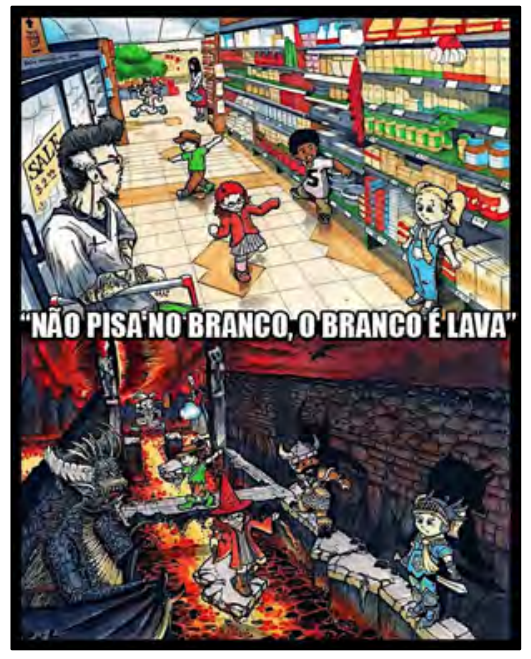

(Figura 1)

A ideia básica da imagem é a de que um determinado espaço é percebido de modo diferente quando se está brincando (ou jogando) e é reorganizado de acordo com regras no caso, a de não pisar em determinado espaço. Além disso, cremos ser razoável afirmar que eventuais observadores dessa brincadeira bastante comum entre crianças podem ser capazes de reconhecê-la como tal, mesmo que não saibam exatamente qual é a regra ou qual o tipo de relação proposta ali - podemos não saber de que brincam ou o que jogam, mas sabemos que estão brincando ou jogando. A noção de que é possível reconhecer essa disposição, sensível e corporal, para brincar e jogar é, em suma, o que norteia este trabalho.

Classificar o jogo como um fenômeno indefinível por causa das variantes que um sistema estabelecido pode sofrer é, em nossa opinião, institucionalizar excessivamente a prática de jogo e considerar como tal apenas aquilo que é oficialmente produzido por determinados sujeitos (empresas, designers etc.), ignorando as práticas existentes no mundo. Nosso trabalho apresenta, portanto, uma mudança de perspectiva: propomos que o jogo enquanto do âmbito do fenômeno e enquanto objeto de análise semiótica é não um objeto físico ou o sistema virtual em si, mas uma competência, uma disposição de sujeitos. É esse ato enunciativo - único, portanto - de atribuir a corpos diversos um valor, ou seja, uma sistematização dos elementos disponíveis no espaço que servirá de base a uma performance, a qual chamamos partida. As bases da teoria semiótica do corpo e da experiência serão explicitadas no Capítulo 2, no qual retomaremos a questão do ato enunciativo e de sua importância na abordagem semiótica do jogo. 
É importante apontar que a noção semiótica não é muito distante da perspectiva ludológica de jogo apresentada por Salen e Zimmerman (2004). Segundo eles:

\begin{abstract}
Games are designed objects that engage culture on several levels. As systems of representation they reflect culture, depicting images of gender $[\ldots]$ as well as portrayals of race and class [...]. In this case, the cultural dimensions of a game are part of the game itself, reflecting values and ideologies of surrounding contexts. As interactive systems, on the other hand, games offer players forms of participation that extend the boundaries of play beyond the edges of the magic circle. From player produced objects like skins, mods, or game patches, to role-playing games in which players explore and alter their personal identity, games have the potential to transform culture. These cultural transformations emerge from the game, to take on a life of their own outside the framework of game play.
\end{abstract}

O poder dos jogos em transformar os contextos em que são jogados, fora do "círculo mágico" - i.e., o espaço ficcional em que as regras do jogo adquirem sentido e força para os participantes - é definido por Salen e Zimmerman como jogo transformativo e, segundo eles, não é algo presente em todo e qualquer jogo. De qualquer modo, os autores salientam o seguinte: "it is not enough to merely point out that games and culture can affect one another. Instead, we need to look closely at the specific relationships that occur between them". Salen e Zimmerman, neste ponto do texto, não entram na discussão a respeito do jogo ser ou não cultura, tomando este segundo termo como sinônimo do termo "contexto", bastante usado em algumas vertentes de Análise do Discurso: referem-se àquilo que rodeia o espaço onde o ato discursivo de jogar se dá e pode fazer sentido. O seguinte exemplo é bastante interessante:

\footnotetext{
The "meaning" of a game of Dominos played on a hot summer night on a Brooklyn street corner, for example, gains richness from a whole slew of contextual factors: the hot, sultry air that provides a perfect acoustical buffer to the slapping ivory tiles; the loose and easy postures of the four Puerto Rican-American men gathered around the makeshift card table; the well-known story of the grand Champion who is said to have never lost a match but who now sits poised to lose. Each of these contextual factos plays a role in qualifying just what the game means at any particular moment.
}

Sentido, para Salen e Zimmerman (e também para a semiótica francesa), é algo que não se limita à mera noção de "significado" extraído a partir de algo, indicando que um jogo não pode significar por si. O sentido é derivado de uma experiência fenomenológica ligada a um processo discursivo de fazer sentido e inexiste antes da experiência do sujeito; deriva 
do encontro deste - portador de todo um arcabouço de experiências, pontos de vista, leituras sobre si e do mundo - com o mundo - que é sempre mundo-para-o-sujeito. A partir disso, várias interpretações podem surgir de um mesmo objeto, como bem apontam Salen e Zimmerman:

Take Ms. Pac-Man, for instance. From a perspective internal to the game, what does Ms. Pac-Man represent? We might say that she representes a dot-munching, ghost busting avatar, or we might refer to the in-game backstory that tells the tale of Pac-Man and Ms. Pac-Man meeting and falling in love. But if we consider Ms. Pac-Man from a cultural point of view external to the game, our Reading of the character changes dramatically. We might see Ms. Pac-Man as a powerful and positive feminist icon, a superior feminist symbol, a powerful sucessor to the original Pac-Man. Or we might view her as a very unfeminist symbol, a derivative character that equates lipstick and a hair bow with the female gender. [...] This process of interpreting games as symbolic objects, as cultural texts that reflects their contexts, is one way of understanding games as culture.

O "mesmo" objeto, Ms. Pac-Man, para mais de um sujeito, pode ser retrógrado ou progressista, a favor ou contra o sistema. O conteúdo crítico não está no jogo em si, mas no olhar que colocamos sobre ele - a máxima atribuída ao linguista suíço de que "o ponto de vista cria o objeto" cabe bem aqui.

Contrastemos, agora, a definição de Salen e Zimmerman com a de Juul (2005):

A game is a rule-based system with a variable and quantifiable outcome, where different outcomes are assigned different values, the player exerts effort in order to influence the outcome, the player feels emotionally attached to the outcome, and the consequences of the activity are negotiable.

Em uma leitura rápida, a definição apresentada acima parece não dizer nada de novo em relação à anterior, porém há algumas noções colocadas por Juul que são de nosso interesse, bem como os aspectos que ele deixa de lado.

Em primeiro lugar, a definição de Juul explicita o fato de que as regras são a base do sistema; a pergunta que colocamos aqui incide sobre essa necessidade de explicitar: há algum sistema não baseado em regras? Se considerarmos "regras" como proibições relacionadas a alguma penalidade ("não jogar lixo no chão", "não fazer barulho depois das 22h"), dificilmente entenderíamos a sistematização de canetas marca-texto coloridas citada acima como um sistema baseado em regras. No entanto, se recuperarmos a noção de valor diferencial e associá-la às regras, a definição de sistema dada por Juul é redundante: a 
partir do momento que uma regra é um investimento de valor a um elemento do sistema, o qual adquire sentido por meio das relações que marcam as diferenças, todo sistema será por definição baseado em regras. Se considerarmos o jogo de Xadrez, definir regras como proibições não parece adequado: evidentemente há restrições quanto às possibilidades que o jogador tem de movimentar as peças, no entanto o que cada uma delas representa no jogo é determinado pelo valor diferencial - o sistema determina não só o que não se pode fazer, mas também o que se pode fazer.

Pensando de acordo com a semiótica greimasiana, o aprendizado de um jogo é correspondente à aquisição de competência necessária à performance localizada no nível narrativo do percurso gerativo do sentido: o jogador, ao ler as instruções do jogo ou depreendê-las por meio do ambiente (digital), adquire o que ele deve e pode fazer, bem como os meios pelos quais esse fazer será realizado - estamos apoiados na ambiguidade do termo poder. Isso parece estar de acordo com a visão de Juul:

The rules of a game provide the player with challenges that the player cannot trivially overcome. [...] Playing a game is an activity of improving skills in order to overcome these challenges, and playing a game is therefore fundamentally a learning experience.

A noção de regra é, portanto, mais ampla que meramente a de restringir e, nesse sentido, a especificação dada pelo autor é redundante.

Os próximos pontos a salientar na definição de Juul dizem respeito ao resultado. Além de associar a ele a qualidade de quantificável (como já haviam feito Salen e Zimmerman (2004)), o autor salienta que ele é variável, que as diferentes variantes têm valores diferentes e que o jogador sente-se ligado emocionalmente a essas variantes. Esta nos parece uma ampliação interessante em relação à definição anterior, tendo em vista que o jogo se baseia na performance em busca de uma sanção, que pode ser eufórica ou disfórica do ponto de vista do jogador. Sem esse engajamento (termo retirado da definição de Salen e Zimmerman) com vistas à obtenção de um resultado eufórico, dificilmente poderíamos pensar em jogo:

Valorization means that some of the possible outcomes of the game are better than others. [...] Positive outcomes are usually harder to reach than negative outcomes - this is what makes a game challenging. A game where it is easier to reach the positive outcome than to not reach it would likely not be played much. (JUUL, 2005). 
O autor também indica que a valorização precisa ser partilhada:

The emotional attachment of the player to the outcome is a psychological feature of the game activity. A player may feel genuinely happy if he or she wins, and unhappy if he or she loses. [...] The spoilsport is one who refuses to seek enjoyment in winning, or refuses to become unhappy by losing. (Idem)

O valor dos resultados é, portanto, também integrado no sistema e, sendo assim, podemos pensar o seguinte em termos semióticos: os valores da sanção são dados pelo destinador, não podendo ser atribuídos livremente pelos destinatários envolvidos (i.e., a autodestinação não é aceitável), sob risco de sanções negativas de outra ordem (tornar-se um estragaprazeres, por exemplo). Trata-se de uma estrutura narrativa em que querer e dever aproximam-se: o jogador (em casos normais) se engaja na atividade espontaneamente e, portanto, quer jogar, mas deve buscar o resultado previamente euforizado pelas regras do sistema, caso contrário a atividade como um todo será disfórica.

Essa especificação dada por Juul parece estender a ideia de conflito apresentada por Salen e Zimmerman (2004); no entanto, há um dado nesta definição que não aparece naquela: o conflito para Salen e Zimmerman é artificial, isto é, definido de acordo com regras e não pertencente ao campo do real. Nesse ponto há uma discrepância enorme com o modelo de Juul, pois o argumento do autor caminha em direção a considerar os jogos como uma atividade semirreal, que conjuga regras com ficção, ou seja, aquelas não estão inclusas nesta. Juul diz explicitamente: "To play a video game is therefore to Interact with real rules while imagining a fictional world, and a video game is a set of rules as well as a fictional world" (2005, grifos nossos) e

\footnotetext{
In having fictional worlds, video games deviate from traditional non-electronic games that are mostly abstract, and this is part of the newness of video games. The interaction between game rules and game fiction is one of the most important features of video games, and it is a central theme of this book.
}

A separação se dá entre jogos abstratos (Futebol, por exemplo) e jogos que projetam alguma espécie de universo ficcional (Final Fantasy, Tomb Raider, Detetive), sendo estes semirreais, pois conjugam elementos da ordem do real (as regras) com construções fictícias (o enredo, os gráficos etc.). A noção de ficção apresentada por Juul não é definida com precisão, mas é possível depreendê-la a partir de trechos como este: 
Let us examine the following statement: "Hamlet is Prince of Denmark" It is a philosophical problem whether this statement is true or not (Pavel 1985, 13-17). On the one hand, there is no real person called Hamlet who is Prince of Denmark. On the other hand, it is more correct to say that Hamlet is Prince of Denmark than to say that he works as a banker. That is, Shakespeare's play describes a fictional world that does not actually exist, but in which there is a character by the name of Hamlet who is Prince of Denmark. "Hamlet is Prince of Denmark" is true in the fictional world that the play creates, and we normally accept the statement "Hamlet is Prince of Denmark" because we take it to refer to the possible world of the play. "Now consider this statement: "Tennis is a game where two people hit a ball using a racket." This statement is true in the normal sense: It is about the real world, and it describes how the game of tennis is actually played.

O critério aqui parece ser a verificação empírica: Hamlet é ficcional, pois não existe ou não existiu ninguém com esse nome que de fato fosse príncipe da Dinamarca; por outro lado, como podemos ver o jogo de tênis sendo jogado no mundo real com as regras descritas, as regras são da ordem do real. O mesmo argumento é usado para o jogo Tetris:

\begin{abstract}
We can make the following statement about Tetris: "In Tetris when you have covered an entire row, it disappears." This is a statement about the real world much like the previous statement about tennis. The rules of Tetris are not physical but programmed, but this does not change the fact that it is a verifiable statement about the real world.
\end{abstract}

Em nosso ponto de vista, esse critério é bastante problemático. Pensemos no seguinte caso: um dos eventos esportivos de maior popularidade no Brasil nos últimos anos tem sido o UFC (Ultimate Fighting Championship), em que diversos lutadores se desafiam no ringue octogonal pelo título, representado por um cinturão. O ringue situado numa arena em Las Vegas é, de fato, um local aonde se pode ir - tem um endereço fixo, horários de funcionamento, lugares onde se pode sentar etc. Os lutadores são fotografados, filmados, entrevistados e, portanto, existem, mas a pergunta que lançamos aqui é: o lutador conhecido como Minotauro é totalmente correspondente a Antônio Rodrigo Nogueira, a pessoa de fora do ringue? O cinturão que ele eventualmente pode receber é um título cujo valor é absoluto? O objeto evidentemente pode ser tocado, mas lhe garante alguma posição de fato fora do "universo UFC"? Mais: devemos considerar esses lutadores como pessoas violentas? Dana White, o "chefão" do UFC, garante que não, que o comportamento dentro do ringue não se reflete fora dele ${ }^{17}$. O Minotauro, portanto, existe dentro do evento, assim como Hamlet. Trata-se de uma persona (máscara, em latim) e não de uma pessoa

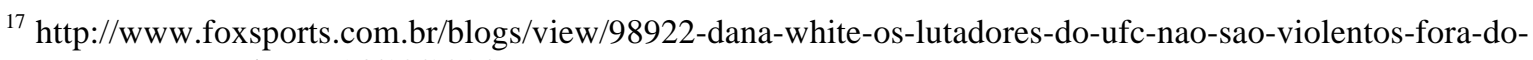
octogono (acessado em 14/10/2014)
} 
empiricamente localizada no mundo. O mesmo poderia ser estendido a tenistas - como é o caso de Venus e Serena Williams, duas irmãs que, na quadra, são rivais ${ }^{18}-$ ou a jogadores de futebol que migram entre clubes considerados inimigos - caso recente de Alexandre Pato, negociado entre Corinthians e São Paulo ${ }^{19}$, mas não necessariamente torce ou deixou de torcer para nenhum dos dois.

Fora do universo esportivo podemos citar exemplos de artistas como Beyoncé e Britney Spears. A primeira revela que, quando sobe aos palcos, não se trata de ser quem ela é, mas de ser Sasha Fierce, um alter-ego mais divertido e solto que, inclusive, protege o verdadeiro "eu" da cantora ${ }^{20}$. Britney, por sua vez, não tem um alter-ego definido, mas cremos ser difícil não considerar incoerente a junção em uma única pessoa empírica aquela que faz suas performances provocantes no palco e a outra que passeia pelas ruas de Las Vegas tomando frappuccino e vestindo moletom - além disso, a cantora já declarou ser tímida e insegura ${ }^{21}$.
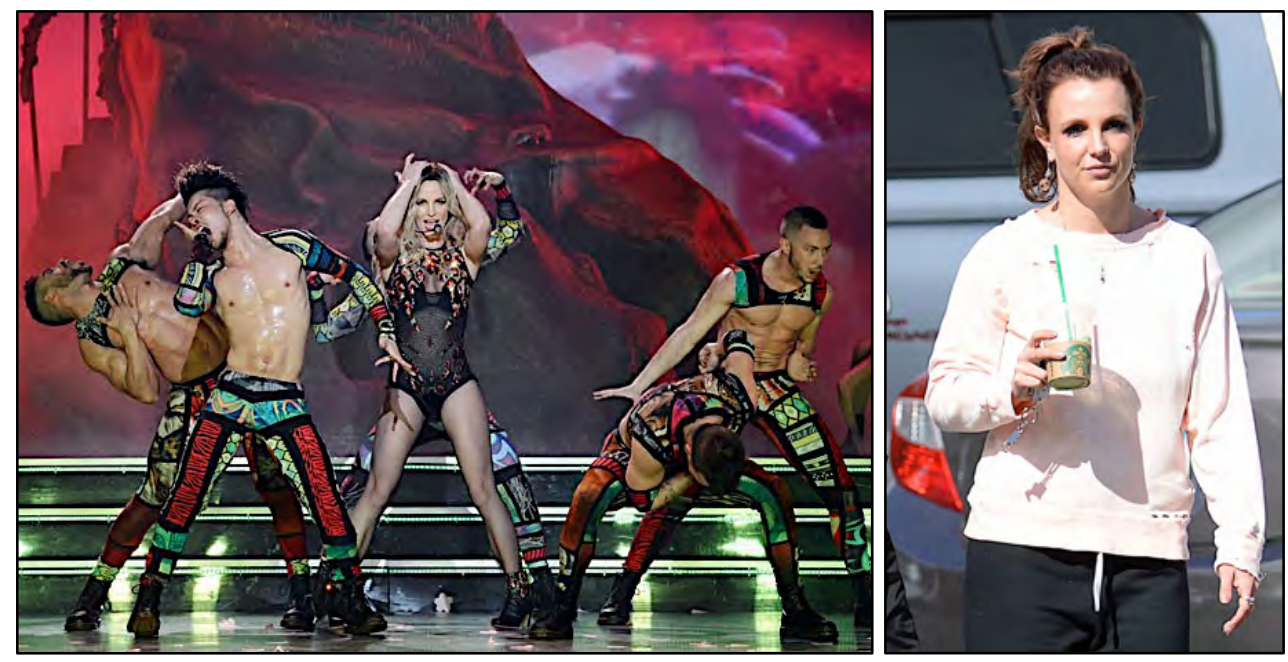

(Figuras 2 e 3: Britney Spears em 2014)

A "definição" de ficção de Juul pode ser problemática ainda em outros níveis: uma personagem de um filme ou seriado que remete a uma pessoa famosa na sociedade e que é interpretada pela própria pessoa - como Steven Tyler, vocalista do Aerosmith, em um episódio da quarta temporada da série estadounidense Two and a Half $\mathrm{Men}^{22}$-, ou em obras de arte baseadas em eventos reais - como filmes sobre o tsunami ou sobre a queda de

\footnotetext{
${ }^{18} \mathrm{http}: / /$ en.wikipedia.org/wiki/Williams_sisters_rivalry (acessado em 14/10/2014)

19 http://www.gazetaesportiva.net/noticia/2014/02/sao-paulo/corinthians-e-sao-paulo-negociam-troca-entrepato-e-jadson.html (acessado em 14/03/2014)

${ }^{20} \mathrm{http}: / / \mathrm{www}$. theguardian.com/music/2008/oct/24/beyonce-sasha-fierce (acessado em 14/10/2014)

${ }^{21} \mathrm{http}: / / \mathrm{www}$.people.com/people/article/0,,20657292,00.html (acessado em 14/10/2014)

${ }^{22} \mathrm{http}$ ://www.ign.com/articles/2006/09/01/aerosmiths-steven-tyler-returns-to-two-and-a-half-men (acessado em 14/10/2014)
} 
Hitler -, seria menos ficcional por isso? Podemos dizer que a obra de arte retrata perfeitamente a realidade empírica ou que ela a "distorce"? O que defendemos aqui não postula nenhuma dessas opções: a obra, seja ela um romance, filme, show de música ou jogo cria algo que se separa da realidade e, portanto, é ficcional, independente de sua relação maior ou menor com algum elemento do real.

Em suma, o que defendemos aqui é a impossibilidade de acesso ao real, tendo em vista que nossa experiência sensível é mediada por simulacros, projeções construídas com base no que cremos ser adequado a cada situação. Nosso critério de avaliação não é, portanto, o de verdade, mas o de veridicção, baseado nos valores postos pelo(s) destinador(es): dizer verdadeiramente de acordo com o gênero, com a atividade proposta. Eis a exigência de adoção de um nome como "Minotauro" para competir, pois o simulacro construído por meio dos traços semânticos desse nome (força, virilidade, falta de compaixão, bestialidade etc.) é mais adequado aos valores propostos pelo UFC que o nome encontrado na certidão de nascimento da pessoa.

A proposta de Juul a respeito das regras fazerem parte do âmbito do real se baseia na complexidade inerente ao ato de jogar: todo jogo, em maior ou menor grau, faz uso do corpo - em palavras cruzadas, utiliza-se tanto a capacidade de raciocínio quanto as mãos para escrever; no jogo de tênis, usa-se o corpo todo. No caso de esportes, há sempre a possibilidade de ferimentos e marcas que perduram no corpo mesmo após o fim do evento, o que toca no último ponto da definição dada pelo autor: as consequências. De acordo com Juul,

\footnotetext{
A game is characterized by the fact that it can optionally be assigned real-life consequences. The actual assignment can be negotiated on a play-by-play, location-by-location, and person-to-person basis. So while it is possible to bet on the outcome of any normally "for-fun" game, it is impossible to enter a casino in Las Vegas and play without betting money.
}

A ideia de que se perde dinheiro real pode parecer contrariar nossa perspectiva de jogo como ficção, porém ressaltamos que o dinheiro, assim como qualquer objeto do mundo real, é ressignificado quando entra em jogo: no Poker, o dinheiro tem valor diferencial dentro do sistema assim como as cartas e, portanto, faz parte do plano ficcional - as apostas ocorrem apenas em determinados momentos e não se pode usar o dinheiro para subornar um outro jogador, por exemplo. O fato de que o dinheiro perdido no jogo é subtraído após o término da partida é uma das consequências negociáveis e é da ordem da 
convenção social da aposta, o que não muda o fato de, dentro do sistema do jogo, a relação entre jogadores e dinheiro ser estabelecida por meio de regras que inscrevem toda a atividade em um campo separado do real - não por acaso os cassinos podem exigir que fichas sejam compradas de modo a não misturar o objeto empírico com os demais elementos do sistema artificial.

Quanto aos esportes, Juul afirma:

\begin{abstract}
There is an important difference between the actual operations of the game and the outcome of the game. The only way for a game to have negotiable consequences is if the operations and moves needed to play the game are mostly harmless. Any game involving actual weapons has strong non-negotiable consequences. This is in itself a point of contention, since many sports can lead to injury and even death. Arguably, part of the fascination with some sports such as boxing or motor sports lies in the fact that they are dangerous. Nevertheless, it is a convention of these games that injuries are to be avoided. Public outrage is likely if a motor sports event has poor security precautions.
\end{abstract}

Novamente, as consequências da realidade parecem colocar o jogo como algo não ficcional. No entanto, o corpo dos participantes não tem o mesmo valor real e frequentemente são criadas formas de evitar contato entre corpos: no Futebol, fazer uso de estratégias para roubar a bola do adversário que criem contato físico é considerado falta não por um purismo em relação às regras, mas porque isso extrapola os limites da ficção. Uma analogia possível é a de atores de teatro ou cinema encenando uma tomada envolvendo lutas: machucar o colega de palco quebra a ficção, pois não faz parte do roteiro previsto para a peça e não contribui de forma alguma para os fins da atividade.

Desrespeitar os limites da ficção é um problema nos jogos, como Juul havia mencionado no caso do jogador que se recusa a corroborar com o estado patêmico esperado pela sanção positiva ou negativa. Salen e Zimmerman (2004) apresentam uma análise mais complexa dos tipos de jogadores que estragam os jogos ao se comportarem fora do permitido pelo gênero, os quais são classificados de acordo com três eixos: a aderência às regras (aos valores do destinador, em nossos termos), o interesse na vitória e a atitude lúdica. Se considerarmos a ideia de Goldstein citada pelos autores, há sempre dois conjuntos de regras em uma atividade de jogo: as ideais e as aplicadas, ou seja, as que de fato ocorrem, muitas vezes subvertendo o conjunto ideal - em termos semióticos, podemos pensar em destinadores diversos atuando, um que sempre mantém a atividade lúdica no plano ficcional (o destinador do conjunto ideal) e outros que desviam o jogador de seu papel dentro da estrutura. O resultado desse embate é a partida efetivamente realizada, que 
pode ser considerada satisfatória ou insatisfatória de acordo com o parâmetro virtual inscrito nas regras do jogo - sanção com base nos valores do destinador e não do antidestinador.

Salen e Zimmerman salientam que não se trata de construir uma tipologia fixa ou de enquadrar o fenômeno em classificações estéreis, mas de fornecer linhas de pensamento fluidas para entender o jogo enquanto atividade significante. $\mathrm{O}$ problema todo para os autores parece ser quando o desvio quebra o chamado "círculo mágico" em que o evento lúdico ganha significado. Semioticamente, não podemos classificar nenhum resultado como desprovido de significado (posto que a significação é feita com base no processo discursivo engendrado pela existência de um sujeito em contato com um fenômeno), mas é possível aproveitar as considerações, se encararmos a falta de significado apontada pelos autores como correspondente, para nós, à quebra da ficção. Vejamos o seguinte exemplo:

\footnotetext{
When a set of Chess pieces are placed in their proper positions on the board and a game begins, the pieces gain meaning. But if, during a game, the action of a spoil-sport wipes the Chess pieces from the board, meaning is violently erased. Removed from their grid positions, the Chess pieces merely represent a collection of scattered figurines. The spoil-sport returns the game to its pre-game state as a collection of parts, no longer the embodiment of the space of possibility set out by the rules of the game.
}

A afirmação de que as regras do jogo tiram as peças de seu estado natural e lhes dão significado vai ao encontro das propostas apresentadas aqui: representando um papel no tabuleiro, estruturalmente, há um conjunto de valores que só fazem sentido dentro do evento; ao espalhar as peças, o estraga-prazeres interrompe o evento ficcional ao introduzir um elemento que não está previsto na virtualidade do sistema - é comparável a um espirro involuntário de um cantor em uma apresentação ou a um equipamento que se desprende do teatro. A ficção é, portanto, frágil, pois se baseia na ressignificação de elementos cujos valores individuais são bem diferentes fora do evento - um chinelo usado para marcar o espaço correspondente ao gol no futebol de rua, o papelão pintado para representar um arbusto etc. Estragar o jogo como no exemplo descrito é evidenciar o engajamento necessário para transformar a figura de madeira em uma temível Rainha que pode a qualquer momento deslocar-se para a linha de frente e ameaçar a segurança de um Rei.

Ainda na problemática do conceito de ficção apresentado por Juul (2005), um jogo como xadrez seria abstrato na medida em que o conjunto de regras reais não está associado a um universo ficcional. O mesmo não ocorreria com jogos como The Legend of Zelda: 
The Wind Waker (Nintendo, 2002), que têm universos ficcionais tão amplos a ponto de o jogo apresentá-los apenas de modo incompleto. De acordo com ele:

In fictional worlds, there is an important distinction between the description of a fictional world and the fictional world as it is actually imagined. The text of Hamlet directly describes a rather small world, mostly a castle in Elsinore with some hints of foreign countries. At the same time, the fictional world of Hamlet is presumed to be as large and detailed as the actual world.

A explicação dada para o fenômeno é a seguinte: "This is because all fiction worlds are incomplete. No fiction exists that completely specifies all aspects of a fictional world".

Contrariamente a essa perspectiva, Ernica (2014) afirma que:

O problema na visão de Juul reside na seguinte falha conceitual: para que um universo ficcional qualquer seja incompleto é preciso haver uma completude inatingida (ou inatingível) cuja existência seja independente do objeto, sendo este apenas um meio de representação. É como uma câmera cuja lente é capaz de captar somente uma parcela do que o olho apreende, e que sabemos estar lá. Porém, ao lidar com fotografia, reconhece-se que fatores como enquadramento, foco e iluminação a tornam um meio de criação, pois o direcionamento do olhar derivado dos fatores mencionados nos faz ver de outro modo, gerando possibilidades de sentido não existentes antes da intervenção do fotógrafo. Da mesma forma, um romancista, ao estruturar uma narrativa, faz uso dos mais diversos atributos da linguagem verbal (sonoridade, ritmo, estrutura morfológica, sintática, etc.) para criar situações as mais diversas, dar um "toque passional" ao texto e, inclusive, fazer com que o objeto não baste em si mesmo, atiçando a curiosidade do leitor para os elementos que ele decide calar. É a própria forma expressiva e seus mais variados atributos que, quando combinados de uma maneira e não de outra, criam a sensação de incompletude, indicando, portanto, que não se trata de objetos cujas limitações permitem-nos apenas retratar a parte e nunca o todo, mas sim de um efeito de sentido produzido por uma organização formal específica, por uma estética da incompletude, o que a descaracteriza, no fim das contas, como incompleta - é uma forma de expansão do perceptivo, não o contrário. (pp. 49-50)

Além disso, há o problema da incoerência apontado por Juul (2005): o fato de que o jogador dispõe de várias vidas contradiz muitas vezes o universo ficcional e só pode ser explicado por meio das regras do jogo (opostas pelo autor à ficção, lembremos). Sobre isso, Ernica (2014) diz:

um universo ficcional, seja ele qual for, é construído a partir dos elementos formais de determinado meio expressivo, o que elimina a possibilidade de incoerência no caso descrito por Juul, na medida em que os elementos considerados destoantes por ele são necessários para que um jogo seja reconhecido enquanto tal e é apenas por meio deles que a narrativa se torna possível [...]Diferente de um romance convencional, é 
comum que jogos trabalhem com outras bases narrativas, determinados por fatores como experiência do evento - em oposição a outras formas mais "contemplativas" de arte - e apresentação hipermidiática de conteúdo - que difere da linearidade do romance ou do filme. Essas características são essenciais para a estética do meio digital, como aponta Murray (1997) e devem ser estudadas em profundidade para que se entenda o que de fato está em jogo quando jogamos e não se analise, como faz Juul, o fenômeno que constitui o jogo digital com o mesmo instrumental moldado para atender às especificidades de outras formas expressivas - motivo pelo qual o autor considera seu objeto incoerente. (p. 51)

O problema da relação entre a ficção, associada à narrativa, e o jogo propriamente dito, ligado às regras, não é abordado exclusivamente por Juul (2005) e, segundo Ranhel (2009), é recorrente nos estudos de ludologia. A seguinte citação de Pearce, feita por ele em seu texto, dá alguma dimensão da problemática:

A primeira (e mais importante) coisa a saber sobre os jogos é que eles são focados no jogar. Diferente de literatura e filmes, os quais estão focados na história, nos jogos tudo gira em torno do jogar e da experiência do jogador. Os designers de jogos estão muito menos interessados em contar histórias do que em criar uma estrutura convincente para jogar. (PEARCE apud RANHEL, 2009, p. 8)

A dicotomia "estrutura versus história" é bastante comum em discussões sobre jogos digitais $^{23}$ e, segundo Ranhel, a convivência de ambos os polos no universo digital se dá de modo complexo devido a sua oposição:

\begin{abstract}
Ainda que ao longo da construção da cultura humana tenham convivido e se influenciado mutuamente, narrativas e jogos possuem naturezas diferentes. Jogos são estruturas nas quais o jogador age, experimenta, vivencia situações. Narrativas descrevem ações passadas. Jogos são um agora, um fazer acontecer no momento em que são jogados. Narrativas baseiam-se em fatos que já ocorreram, suas relações de causa e consequência. Há várias diferenças entre a narrativa tradicional e os jogos; contudo, quando ambas as atividades migram para os computadores, começa a haver uma fusão, uma mescla entre elas. [...] Vimos também que jogos, no mundo real, são geralmente estruturas compostas de um espaço definido, com regras definidas, com um tempo definido, no qual o jogador é um agente pleno, ou seja, é a ação dele que faz a história do jogo. A história de um jogo é emergente, de baixo para cima, é um fenômeno Button-up [sic]. Por outro lado, as narrativas tradicionais são estruturas Top-down. (Idem, p. 17)
\end{abstract}

\footnotetext{
${ }^{23} \mathrm{Cf}$.

https://www.facebook.com/MachinimaBrasil/posts/564334606941760?comment_id=6016714\&offset=0\&tot al_comments $=40($ Acesso em 14/10/2014)
} 
A aparente dicotomia entre emergência da narrativa a partir da ação do jogador e a narrativa retirada de um livro por meio do processo de leitura é, para Ranhel, a principal diferença entre as formas: estudar fenômenos de emergência sistêmica seriam do âmbito da ludologia, enquanto atentar-se às narrativas prontas que o jogador acessa seriam da ordem da narratologia - campos diferentes, porém complementares do estudo dos jogos, compostos como um espaço de limiar entre o sistêmico e o narrado.

A oposição feita por Ranhel (e por diversos ludologistas, como já apontamos) não pode ser sustentada em uma leitura norteada pela semiótica francesa, pois a ideia de narratividade funciona como base epistemológica para a produção do sentido: mesmo não havendo um enredo, todo e qualquer objeto apreendido pelos sentidos irá tornar-se inteligível por meio de um processo de discretização da experiência sensível organizado em um percurso, cujo centro consiste em uma estruturação lógico-narrativa. Segundo Ernica (2014),

\begin{abstract}
A noção de que a estrutura de nossa cognição está baseada em uma narrativização de conceitos abstratos não é exclusiva da semiótica francesa; Ricoeur (2006, pp. 105-138) determina que um dos pontos definidores da identidade de um sujeito é justamente a elaboração de uma progressão baseada, dentre outros aspectos, na memória e na promessa: o sujeito que foi deve ser reconhecido naquele que ainda não é, mas se encontra em devir. Essa progressão não pode ser entendida senão por uma conexão causal (ou por algo que se assemelhe a ela), demonstrando que a narratividade, que pode, inclusive, ser entendida como a capacidade de narrar(-se), é fundamental para o reconhecimento cognitivo tanto dos outros como de si mesmo. (p. 67)
\end{abstract}

O argumento semiótico é usado para embasar a ideia de estética da incompletude presente no artigo, a qual consiste na ampliação da informação narrativa constante do enredo por meio da narrativização dos demais elementos do objeto. Segundo Ernica (Idem, pp. 72-3), a questão da experiência estruturada é justamente a base da narratividade em jogos digitais, não sendo possível opor os conceitos, como faz Ranhel (2009, p. 18), que sugere uma espécie de proporção inversa entre o narrativo e o estrutural. O tema será discutido em maior profundidade nos Capítulos 3 e 4.

A breve reflexão acerca das considerações sobre o jogo digital tem por objetivo extrair do que se encontra descrito e problematizado nas pesquisas ludológicas algumas noções de base para uma visada semiótica do problema. Do que foi discutido até o momento, tomemos o seguinte: 
1. Jogos não são meramente objetos físicos, mas sistemas que lhes dão forma, i.e., atribuem valores diferenciais a eles. É possível usar partes de um jogo de modo não lúdico e frequentemente elementos cotidianos são ressignificados em uma situação de jogo;

2. Independente do estabelecido pelos criadores, todo jogo é passível de mudanças, de modo a adequar-se às mais diversas situações de enunciação, que, ao fim e ao cabo, são o momento de atualização e realização das virtualidades do sistema;

3. As regras de um jogo não dizem respeito ao mundo "real" e garantem que a atividade lúdica tenha seus próprios valores veridictórios. Os jogadores não se confundem com as pessoas empíricas e as consequências da atividade lúdica podem ser negociadas. Quando o jogo extrapola seus limites, frequentemente é mal visto, evitado ou regulamentado. A possibilidade de as consequências ultrapassarem as fronteiras do ficcional evidenciam o jogo como atividade de limiar;

4. A questão dos enredos em forma de jogo é bastante complexa, na medida em que há a necessidade de uma estruturação narrativa em forma de experiência presente, o que, para muitos, é uma incompatibilidade.

Esses quatro pontos resumidos parecem cobrir as questões discutidas neste capítulo até o momento e é a partir deles que se delineia a postura teórica adotada nesta dissertação: havendo uma lacuna aparente nos estudos ludológicos no que diz respeito à narrativização e à organização de enredo em forma lúdica, é preciso analisar de modo mais detido o fenômeno de mescla apontado por Ranhel (2009) em sua especificidade. Em vez de considerar o jogo digital como um veículo narrativo de segunda ordem, incompleto, incoerente ou até mesmo primário em relação a outras formas de arte (como nos sugere a leitura de Stallabrass (1996)), o objetivo deste trabalho é aprofundar-se na questão narrativa, sob a luz da semiótica francesa, abordando o problema da seguinte maneira: como uma estrutura de conflito aparentemente simples pode ser estruturada em suas bases de modo a permitir que o jogador vivencie conteúdos narrativos complexos?

Como estudo de caso, foi escolhida a paixão Vingança tal como formulada no percurso das personagens Lightning e Hope do jogo Final Fantasy XIII, e nosso desafio será demonstrar como um conteúdo da ordem do ser pode ser traduzido em uma estrutura do fazer, como é a do jogo. O Capítulo 4 será dedicado a essa análise, baseada na metodologia teórica explicitada no Capítulo 2, dedicado à revisão da definição de jogo sob 
a luz da semiótica das paixões e também da semiótica tensiva, e no Capítulo 3, que tratará das formulações narrativas cristalizadas no gênero RPG, ao qual pertence Final Fantasy XIII. 


\section{Capítulo 2}

\section{A escolha epistemológica por trás do estudo semiótico do jogo}

No primeiro capítulo foi discutida a posição do estudo dos jogos no quadro mais amplo das ciências humanas, com destaque para a abordagem discursiva. A partir daqui, a abordagem será feita de modo diferente: partiremos das conclusões e dos problemas teóricos constantes do Capítulo 1 com o intuito de propor uma visada semiótica para o estudo analítico do jogo enquanto objeto autônomo de significação.

Não se trata, portanto, de falar sobre a posição dos jogos na sociedade, nem de discutir interpretações a respeito do conteúdo de um jogo específico, mas de uma descrição dos mecanismos de produção de sentido comuns aos diversos jogos presentes em nossa vida cotidiana, sejam eles digitais ou não; não se pretende discutir o que um jogo significa, mas como ele significa. Essa abordagem traz, como não poderia deixar de ser, algumas implicações teórico-metodológicas que é preciso explicitar.

\subsection{Paixões, corpo e tensividade}

Considerar que há um processo de significação em um jogo - evento participativo centrado no aqui-agora - coloca em evidência um posicionamento acerca da significação em si: ela não é dada, nem construída a priori em um objeto, mas se constitui em um ato, único e irreprodutível, a que chamamos de semiose. Segundo o Dicionário de Semiótica (GREIMAS; COURTÉS, 2012, pp. 447-48), semiose

\footnotetext{
É a operação que, ao instaurar uma relação de pressuposição recíproca entre a forma da expressão e a do conteúdo (na terminologia de L. Hjelmslev) - ou entre o significante e o significado (F. de Saussure) -, produz signos: nesse sentido, qualquer ato de linguagem, por exemplo, implica uma semiose.
}

Essa herança teórica hjelmsleviana é reconhecida por Fontanille (2011, pp. 3-4), que coloca como uma das bases da teoria semiótica o tratamento dos dois planos da linguagem como funtivos de uma função: a capacidade que a linguagem tem de significar depende da conjugação de um Plano da Expressão a um Plano do Conteúdo, ambos divididos em 
forma (o recorte de limites distintivos, que define valores) e substância (a "matéria" bruta recortada pela forma). No caso da linguagem verbal, poderíamos entender que o fone [p] torna-se um fonema na língua portuguesa na medida em que seus traços fonéticos (oclusivo, bilabial, não vozeado) fazem parte de um sistema em que contrastam com outros, como, por exemplo, os do fone [b] (oclusivo, bilabial, vozeado), gerando uma diferença relevante quando realizada ("panda" é diferente de "banda") e, por conseguinte, os fonemas /p/ e /b/. No plano do conteúdo teríamos um conteúdo específico como "carne bovina" que, em português, exige a conjugação de um substantivo com um adjetivo em um sintagma, enquanto a língua inglesa utiliza apenas o substantivo "beef", sem a necessidade de um especificador; poderíamos dizer que a língua portuguesa recorre a uma perífrase enquanto a inglesa apresenta um item lexical preciso. Cabe salientar que, apesar de passíveis de estudo isolado, os planos da linguagem são interdependentes, como bem demonstram nossos exemplos; para explicarmos uma diferença de forma de expressão que gera os fonemas $/ \mathrm{p} / \mathrm{e} / \mathrm{b} /$ recorremos a um contraste semântico e o contraste no plano do conteúdo evidentemente é notado por meio da cadeia de sons (ou letras impressas, no caso da leitura). O problema apontado por Fontanille no modelo é a falta de desenvolvimento teórico acerca do operador da função, i.e., aquele que vai conjugar na enunciação os dois planos produzindo a semiose.

No começo da década de 90, o estudo das paixões empreendido por Greimas e Fontanille (1991) colocou em pauta o sensível, o papel do corpo e as pré-condições de significação. Segundo eles,

\footnotetext{
L'instance de l'énonciation est, de ce fait, une véritable praxis, un lieu de va-et-vient entre des structures convocables et des structures intégrables, instance qui concilie dialectiquement la génération - par la convocation des universaux sémiotiques - et la gènese - par l'intégration des produits de l'histoire. Les configurations passionnelles, por ne parler que d'elles, sont de ce fait situées au carrefour de toutes ces instances, puisqu'elles requièrent, pour leur manifestation, certaines conditions et pé-conditions spécifiques d'ordre épistémologique, certaines operations particulières de l'énonciation et, enfin, des "grilles" culturelles qui se présentent soit déjà intégrées comme primitifs, soit en cours d'intégration à un sociolecte ou un idiolecte. (pp. 11-2)
}

A instância de enunciação é sempre mediada pelo corpo; é nele "que le monde se transforme en sens [...], que les figures extéroceptives s'intériorisent et que la figurativité peut alors être envisagée comme un mode de pensée du sujet" (p. 12). O sentir é próprio do corpo, porém não há inocência, um sentir puro: 
elle [a mediação do corpo] ajoute, lors de l'homogénéisation de l'existence sémiotique, des catégories proprioceptives qui en constituent en quelque sorte le "parfum" thymique et sensibilise même - on dira ultérieurement "pathémise" - par endroits l'univers de formes cognitives qui s'y dessinent. (Ibidem)

Esse processo, que ultrapassa todo e qualquer universo semiótico, é baseado na suspensão do elo entre as "figuras do mundo" e seu "significado extrassemiótico", e sua substituição, na enunciação, por outros modos de representação e articulação semióticas (pp. 12-3). Quanto a isso, os autores acrescentam: "ce qui leur [às figuras do mundo] arrive de plus remarquable, en l'occurrence, c'est que les figures du monde ne puissent 'faire sens' qu'au prix de la sensibilisation que leur impose la médiation du corps." (p. 13)

É também pela mediação do corpo que a ideia de estado, dividido entre os estados de coisa - pontos de partida e de chegada da transformação empreendida pelo sujeito da ação - e os estados de alma - competências e condições necessárias para a ação -, torna-se algo homogêneo e contínuo, que não se resume à polarização entre sujeito e mundo (Ibidem). Nas palavras dos autores:

En d'autres termes, l'homogénéisation de l'intéroceptif et de l'extéroceptif par l'intermédiaire du proprioceptif institue une équivalence formelle entre les "états de choses" et les "états d'âme" du sujet. On ne saurait trop insister, ici encore, sur le fait que si les deux conceptions de l'état [...] se réconcilient dans une dimension sémiotique de l'existence homogène, c'est au prix d'une médiation somatique et "sensibilisante". (pp. 13-4)

A formação das modalidades narrativas e da aspectualização discursiva teria origem nesse nível em que sujeito e mundo perceptível ainda se encontram homogeneizados. O sentido nasceria a partir da cisão desse estado de "tensividade fórica"24 (p. 20) introduzida "par l'accident, la fracture, l'intrusion insolite du vivant" (p. 25); instaurar um sujeito operador de somações é o primeiro passo para uma espécie de alquimia: o sentido surgiria a partir de um caldeirão borbulhante ${ }^{25}$, contendo tanto objeto quanto sujeito, com suas ideias e pré-conceitos sobre o que quer que seja o texto em questão. Isso, no entanto, não é o sentido, pois ali só podemos delinear alguns fios de vapor como resultado, os quais, se não forem controlados, condensam-se e caem

\footnotetext{
${ }^{24}$ As definições de tensividade e foria serão melhor trabalhadas mais adiante com base em Zilberberg (2011). Por ora, é suficiente entender o termo "tensividade fórica" como um complexo de movimento, como processo aspectual que se instaura na enunciação.

${ }^{25}$ Zilberberg $(2011$, p. 72$)$ fala na foria como efervescência.
} 
novamente no caldeirão, numa espécie de loop infinito que não é capaz de produzir sentido - como o estupor, paixão associada por Greimas e Fontanille ao puro sentir:

\begin{abstract}
Tout se passe comme si l'intensité passionnelle - notion à définir neutralisait le sujet et le plongeait dans une couche plus profonde du parcours génératif, ou encore, comme si la remonté vers la valeur de la valeur, à partir de l'objet de valeur proprement dit, s'accompagnait d'une intimité plus étroite avec une zone "énergétique" où prendrait naissance la passion. Il en est de même avec la "stupeur", qui subit une condensation comparable, figeant le sujet dans un pur sentir, jusqu'à annuler le sentir lui-même: la "stupidité" n'est-elle pas une régression à un état de tensivité d'avant la vie, un point limite entre le vivant et le non-vivant? (Idem, pp. 24-5)
\end{abstract}

É apenas com a intervenção do sujeito e de sua somação que esse sentido pode surgir. Podemos imaginar isso metaforizado em um sistema de tubos de vidro que captam esse vapor e o direcionam em um percurso até um recipiente. Durante o percurso pelo sistema de tubos, o sujeito, que agora se torna operador, vai moldando o vapor com os elementos da tubulação, colocando mais ou menos pressão, direcionando para este ou aquele caminho dentro dos tubos. O resultado é, portanto, um sentido único, oriundo não do objeto, nem do sujeito e nem do sistema de tubulações, mas de um arranjo complexo que o molda e o direciona de acordo com a situação de enunciação. O "vapor" é o que Greimas e Fontanille chamam de protensividade:

Que la tensivité originelle - tension vers l'un et débordement du tropplein - éclate, et le "positionnement", la polarisation de ce qui cesse d'être l'un, se pose comme un premier événement décisif. La polarisation cumulative des énergies n'est pourtant pas encore leur "prise de position" et n'implique pas la discrétisation des pôles, qui ne peut résulter que de la projection cognitive du discontinu. Dans ces conditions, il n'est pas encore possible de parler des "positions actantielles", mais seulement de prototypes d'actants, des presque-sujets et des presque-objets, de la protensivité du sujet, por employer le mot de Husserl, et de la potentialité de l'objet. (p. 25)

A protensividade é algo anterior à categorização e não contém, portanto, valores, apenas sombras de valores, denominadas valências, que posteriormente serão convertidas em valores (pp. 26-9; 47-8); trata-se de sentido em devir ${ }^{26}$. A ação do sujeito operador é de "segmentação", uma intervenção que discretiza o contínuo tensivo-fórico e delimita categorias inteligíveis, valores e papéis actanciais que, posteriormente, serão revestidos

\footnotetext{
${ }^{26} \mathrm{O}$ percurso gerativo seria fruto da discretização feita pelo sujeito e não algo presente no texto a priori.
} 
temática e figurativamente. A ideia é de que tudo o que está na superfície discursiva ressoa nas bases do sentido, na espécie de "massa" que se forma quando o corpo homogeneiza a experiência sensível.

As direções apontadas por Greimas e Fontanille (1991) vêm sendo retomadas ao longo do desenvolvimento da teoria até os dias atuais. Seria exaustivo e fugiria do escopo deste trabalho listar todas as contribuições e posições tomadas acerca do assunto. Por questões de pertinência, limitaremos a uma breve exposição de duas "correntes" diferentes: a que coloca o corpo como foco (FONTANILLE, 2011) e a que elege a tensividade como seu objeto (ZILBERBERG; FONTANILLE, 2001; ZILBERBERG, 2011). É preciso deixar claro, antes de tudo, que não se trata de uma oposição entre dois modos diferentes e incomunicáveis de fazer semiótica; ao contrário, são duas visadas complementares, cujos pontos de diálogo serão salientados aqui e problematizados de acordo com as questões específicas suscitadas pelos jogos digitais.

\section{$O$ corpo e a semiose}

O corpo não é quinhão exclusivo da teoria semiótica. Segundo Fontanille (2011):

\footnotetext{
Dans le discours de la plurpart des sciences humaines, le corps est un thème omniprésent depuis une vingtaine d'années: l'histoire, la sociologie, la poétique, l'anthropologie et la philosophie, la communication et la mercatique, parmi bien d'autres, en on fait un motif de renouvellement et d'actualisation. (p. 1)
}

A "encarnação" das mais diferentes correntes teóricas, no entanto, não vem de modo gratuito ou leviano, pois "l'éviction du corps, tout comme son retour, est de fait l'instrument d'autres décisions épistémologiques ou méthodologiques" (Idem, p. 2) e, evidentemente, há toda uma reflexão que a acompanha; trata-se, ao fim e ao cabo, de uma revisão que pode até mesmo mudar o modo como uma teoria é concebida. No caso da teoria semiótica de linha francesa, o corpo aparece nos anos $80 \mathrm{com}$ as temáticas passionais (Ibidem), porém não é esse seu foco:

Car le véritable gain théorique et méthodologique de la sémiotique des passions n'est pas le "retour du corps" ou la prétendue sémiotique du continu, mais bien la syntaxe passionnelle, la constitution de séquences de pathèmes (elles-mêmes dérivées de la syntaxe modale), résultat scientifique bien identifié et reconnu par tous les sémitiociens, à l'aune 
duquel la thème du corps fait figure de ritournelle trop convenue. Si une réflexion sémiotique sur le corps est souhaitable, ce n'est donc pas pour conforter une sémiotique des passions, mais bien pour ouvrir un nouveau domaine d'investigations, et ce nouveau domaine sera pour nous celui de la sémiotique de l'empreinte. (p. 3)

É preciso, portanto, entender qual é o novo tipo de semiótica que surge com o advento do corpo. Para tanto, faz-se mister verificar em nome de quê ele foi deixado de lado até então. Segundo Fontanille (Ibidem), isso se deve tanto ao formalismo e logicismo da linguística estrutural dos anos 60 quanto pelo foco no desenvolvimento da semiótica da ação.

No que concerne à função semiótica elementar, herança de Saussure e Hjelmslev, o corpo torna-se indispensável quando se considera o operador necessário para reunir os dois planos de uma determinada linguagem:

qu'on le traite comme siège, vecteur ou opérateur de la sémiose, il apparaît comme la seule instance qui soit commune aux deux faces ou aux deux plans du langage, et qui puisse fonder, garantir ou réaliser leur réunion en un ensemble signifiant. (Idem, p. 4)

Da mesma forma, as conversões entre os níveis do percurso gerativo de sentido, consideradas sob uma ótica fenomenológica, carecem de um sujeito epistemológico "doté d'un corps, qui perçoit des contenus signifiants et qui en calcule et projette les valeurs." (Idem, p. 5) Isso, evidentemente, encontra-se já problematizado em Greimas e Fontanille (1991), onde se reconhece que é a partir de uma operação de sujeito que a protensividade é moldada em categorias. No entanto, a tomada de posição feita por Fontanille (2011) dá lugar "à l'acte manqué, à la maladresse et à la péripétie, autant de phénomènes qui étaient effacés ou exclus comme non pertinents dans une reconstruction rétrospective de la logique de l'action." (p. 6) Se o foco da semiótica das paixões é encontrar as operações lógicas feitas a partir do sujeito, a semiótica da "marca" (ou da "impressão"), como postula Fontanille, está interessada na interferência do corpo enquanto carne, que se impõe e transcende a noção logicista de semiose, instaurando uma visada fenomenológica.

A operação semiótica que se concentra no corpo - a qual, segundo Fontanille (Idem, p. 11) relaciona as percepções do mundo exterior com as do interior, formando respectivamente a expressão e o conteúdo de um objeto semiótico a cada novo ato e 
indicando, assim, que não há relação alguma a priori entre os planos - é um ato, uma tomada de posição do corpo próprio do sujeito

qui marque ainsi le monde sensible d'une frontière imaginaire, éphémère et pourtant parfaitement efficace, puisqu'elle le rend signifiant et intelligible. Mais, de ce fait même, il faut admettre que la fonction sémiotique élementaire est indissolublement liée à la distinction corporelle entre le "propre" et le "non propre" (le corps propre et ce qui n'est pas lui), distinction dont le corps lui-même est l'opérateur. Ainsi se définit, en première instance, le "corps-actant". (pp. 11-12)

A ideia de corpo-actante é desdobrada por Fontanille em duas questões fundamentais: o actante enquanto corpo e o corpo enquanto actante. Segundo o autor:

\begin{abstract}
Il s'agit, d'un côté, d'examiner les conséquences d'une conception de l'actant qui ne serait plus seulement formelle, et qui reconnaîtrait que ses rôles dans les transformations narratives sont déterminés par des propriétés corporelles, essentiellement des matières et des forces, un substrat et une énergie. Et, de l'autre côté, de comprendre par quel processus et sous quelles conditions un corps devient un actant, que cet actant soit une instance de l'énonciation, ou un actant narratif de l'énoncé. (p. 12)
\end{abstract}

A concepção do actante como corpo passa por sua divisão (teórica) entre carne, um núcleo sensório-motor, dotado de forças de resistência e impulsão (Ibidem), e corpo próprio, portador de uma identidade em construção e em devir, aos quais Fontanille chama, respectivamente, de Moi e Soi (p. 13).

As diferenças são explicitadas pelo autor, situando-as em momentos diferentes do processo de significação tal como o concebemos:

Le Moi peut donc se manifester, par exemple, dans le cas particulier d'un actant de la parole, comme "locuteur en tant que tel" (O. Ducrot), l'individu concret qui articule, bafouille, crie, etc.; c'est aussi, en raison de la prise de position dont il est responsable, le point de repère des coordonnées du discors, et de tous les calculs de rétention et de protension. Il est à la fois référence déictique, centre sensori-moteur, et pure sensibilité, soumise à l'intensité des pressions et des tensions qui s'exercent dans le champ de présence. (Ibidem)

Ou seja, trata-se da instância concreta, de onde provém o sentir; é o momento em que as tensões do campo de presença - que Zilberberg (2011) associa às valências - incidem sobre o sujeito. Em contrapartida, o Soi 
se construit en revanche dans et par l'activité de production des sémiotiques-objets, et tout au long de leur déploiement syntagmatique. Il est donc soumis à l'alternative posée naguère par Ricoeur: d'un côté, une construction par répétition, par recouvrement et confirmation de l'identité de l'actant par similitude (le Soi-idem), et, de l'autre côté, une construction par maintien et permanence d'une même direction et d'un même projet d'itentité, malgré les interactions avec l'altérité (le Soi-ipse).

É, portanto, a identidade do sujeito construída a partir das operações inteligíveis (regidas pelo sensível, como bem aponta Zilberberg (2011)) oriundas da cisão entre sujeito e mundo previamente apontada em Greimas e Fontanille (1991).

As duas instâncias estão em uma relação de pressuposição (dependência, no fim das contas) e de interdefinição, sendo o Soi uma projeção do Moi, e este, um ponto de referência daquele em sua construção. A separação entre as instâncias corporais é, portanto, puramente teórica. O que interessa a Fontanille (2011, p. 14) é verificar como se forma uma identidade a partir das pressões e tensões ao qual o corpo está submetido. As interações entre matéria e energia dariam lugar às formas e forças que tornam possível descrever aquilo que o autor chama de constituição figural do corpo-actante (Ibidem). As duas forças reconhecidas, a de animação e de inibição, precisam auto-organizar-se e autodistribuir-se para engendrar uma forma significante em movimento que dá origem a uma forma actancial, a um ato inscrito na ordem do mundo (p. 15) e que, assim, pode fazer sentido. A dinamicidade descrita aqui pode ser facilmente relacionada à semiótica tensiva, sobretudo em sua dinamicidade direcionada - a ideia de vetor é recorrente em Zilberberg (2011).

A noção de inércia é particularmente interessante nesse contexto de valorização de movimento:

de l'ensemble disparate de ces forces, se dégagent des forces opposées, antagonistes; si les unes sont dispersives, les autres sont cohésives; si les unes sont excitatrices, les autres sont inhibitrices; et l'ensemble est configuré comme "schème dynamique". (Ibidem)

Sendo os atributos de cada força diferentes para cada corpo, é o princípio de inércia - que pode ser entendido como uma forma de resistência do corpo - que garante não só a singularidade, mas também a possibilidade de autonomia e identidade corporais (p.16).

Fala-se também em memória do corpo, na capacidade de aprendizagem e de autoconstrução (p. 17), todas elas ligadas à semiótica da marca a que almeja Fontanille e que é de grande interesse para este trabalho: pensar o jogo como um sistema não é suficiente 
quando o consideramos um objeto de sentido, na medida em que, para que os valores nele inscritos sejam realizados na enunciação, é preciso que um sujeito os tome para si e, ao fazê-lo, converta-se em um elemento do sistema; trata-se de assumir uma identidade de jogador, submeter seu próprio corpo a uma transformação, muitas vezes literal, em que cada uma das partes é ressignificada de modo a figurar um conjunto lúdico coerente com o horizonte de valores proposto pelo jogo.

Nesse viés de leitura, a possibilidade de resistência do corpo proposta por Fontanille permite, no âmbito da teoria, que haja espaço para entender o jogo como evento de limiar: havendo inércia, ou seja, uma busca pela manutenção da autonomia e da individualidade, há também variações e divergências de "estilo" nos jogos - dois tenistas diferentes não jogam do mesmo modo, por exemplo -, concepções estratégicas diferentes, contusões e cãibras etc. Ignorar o esforço do corpo em manter-se como tal é considerar o jogo como atividade meramente mecânica, uma reprogramação total da percepção do indivíduo, e negar aos "ruídos" a possibilidade de significar. O trecho a seguir é extremamente importante para entender essa dinâmica:

\begin{abstract}
La schématisation narrative traditionelle présuppose soit un actant sans corps, soit un actant parfaitement maître de son corps, un corps qui dans ce cas ne fait que ce qui est programmé, qui n'est en somme rien d'autre qu'un lieu d'effectuation pragmatique des actes calculables à partir d'un programme narratif. Or on sait bien qu'aucun acteur humain ne peut être ainsi programmé, et que, tout au contraire, la dramatisation de l'action humaine implique un corps imparfait, qui menace à tout moment d'échapper au contrôle et au programme, et d'imposer ses propres contraintes et exigences; la dramatisation du sport de haut niveau, par exemple, ne se suffit pas du conflit entre les adversaires; elle se nourrit abondamment des défauts, des maladresses et des accidents dans les séquences gestuelles; c'est justement ce qui fait que le récit sportif est un drame humain, et que la compétition est un combat entre des hommes et pas entre des machines (p. 19)
\end{abstract}

A programação do actante é considerada uma das pressões que se exercem sobre o corpo (p. 20). Considerando as regras de um jogo como uma forma de programação por meio de valores, a atividade como um todo pode, em nossa chave de leitura, ser estudada por meio das dinâmicas do nível tensivo propostas por Zilberberg (2011). Voltaremos a isso mais adiante.

De acordo com as relações entre as instâncias do corpo (Moi, Soi-ipse e Soi-idem), a ação é vista de acordo com a tomada de posição: há três operações identificadas por Fontanille, as quais dependem das correlações tensivas entre o que ele chama de valências 
e correspondem a regimes narrativos de revisão axiológica, de eficácia da economia narrativa e de ética (FONTANILLE, 2011, pp. 26-8). Trata-se de rever a ideia de narratividade como somente a busca por um objeto de valor, incluindo os "acidentes de percurso", as pausas, a errância e outras formas consideradas "inacabadas" da ação em uma esquematização que lhes confere de direito o estatuto narrativo que tinham de fato. Nas palavras de Fontanille:

En effet, dans le modèle que nous venons de proposer, loin de signaler une quelconque inefficience de l'actant ou une perturbation insignifiante de la logique narrative, ces formes apparemment inabouties de l'action indiquent au contraire que l'actant est toujours soumis au contrôle interne des instances qui le composent, et aux tensions entre ces instances, mais d'une autre manière que celle qui définit l'action programmée; ces autres formes de l'action sont donc légitimement schématisables et signifiantes. (Idem, p. 28)

As considerações de Fontanille, brevemente expostas aqui, salientam a importância de considerarmos a semiose em suas bases e relacionar o corpo-carne e a identidade ao processo contínuo de complexificação lógica e categorização já conhecido do percurso gerativo - a ideia de contínuo já anunciada em Greimas e Fontanille (1991). No entanto, como apontamos anteriormente, não basta identificar as diversas instâncias e problemas relacionados ao corpo; será preciso esclarecer melhor o que é a tensividade inerente ao processo e que incide sobre a carne do sujeito que se constrói ao longo da significação ao mesmo tempo em que a constrói.

\section{A tensividade}

A questão das valências apontada em Fontanille (2011) refere-se, como o próprio autor aponta, ao desenvolvimento teórico encontrado em Zilberberg e Fontanille (2001), em que se discorre largamente sobre a tensividade inerente à significação. Segundo os autores:

O termo valência foi adotado em semiótica para dar consistência a uma constatação muitas vezes verificada na análise dos discursos concretos: o valor dos objetos depende tanto da intensidade, da quantidade, do aspecto ou do tempo de circulação desses objetos como dos conteúdos semânticos e axiológicos que fazem deles "objetos de valor". Morfologia dos objetos, modulações dos processos e da prática de colocá-los em circulação: tratase, pois, de atribuir, de fato, um correlato ao valor propriamente dito e de controlar a distinção entre, de um lado, os investimentos semânticos 
dirigidos aos objetos de valor e, de outro, as condições tensivas e figurais que sobredeterminam e governam os primeiros. O que significaria que nem o conceito de valência, nem o conceito de valor são auto-suficientes: eles só adquirem sentido como partes integrantes de uma semiose imanente em cujo interior a valência seria a manifestada e o valor, o manifestante. (p. 16)

E ainda:

A apreensão paradigmática da valência tem por objeto restabelecer ou precisar o liame entre a definição e o paradigma [...] compreender como, munida de sua definição, uma grandeza semiótica intrinsecamente complexa pode inscrever-se num inventário regrado de oposições. Todas as definições são "verdadeiras", na medida em que elas repousam sobre uma divisão, e "falsas", pois que os objetos, mesmo os mais comuns, estão expostos a surpreendentes flutuações definicionais. (p. 18)

Trata-se, como fica claro no trecho a seguir, de uma questão relativa ao ponto de vista: "Todas as definições praticam uma divisão, instalam uma desigualdade e um conflito entre duas direções e cada uma dessas direções por si mesma um efeito de perspectiva." (Ibidem)

A correlação entre valências é imperativa, na medida em que é a partir da tensão aí gerada que o valor pode emergir (p. 20); o nível tensivo - na esteira do que já foi discutido a partir de Greimas e Fontanille (1991) - é o lugar do corpo do sujeito:

Globalmente, as valências definem-se, pois, por sua participação numa correlação de gradientes, orientados em função de sua tonicidade sensível/perceptiva. Isso quer dizer que, de imediato, um observador sensível é instalado no cerne da categorização, como o próprio lugar das correlações entre gradientes semânticos. Em outras palavras, a "caixa preta" da semiótica das paixões, a saber o corpo próprio do sujeito que sente, encontra aqui uma definição oblíqua e inesperada: o corpo próprio é o lugar em que se fazem e se sentem, de uma só vez, as correlações entre valências perceptivas (intensidade e extensidade). (ZILBERBERG; FONTANILLE, 2001, p. 20)

A relação entre valências e valores é explicitada em termos de função:

O valor é então a função que associa as duas valências e essas duas valências (esses gradientes orientados e correlatos) são os funtivos do valor. A valência pode, pois, dar margem a duas análises: de um lado, ela é uma orientação gradual num conjunto de grandezas tônicas ou átonas; de outro, ela varia sob o controle de uma valência, por relação à qual é percebida como associada e dependente. (p. 22) 
Sendo que a operação necessária para isso é a da diferença, ou seja, uma intervenção de discretizações e da polarização, tal qual estava previso em Greimas e Fontanille (1991). Nas palavras de Zilberberg e Fontanille (2001):

\begin{abstract}
A rearticulação das valências em valores, no espaço semionarrativo, supõe que as dependências/independências sejam convertidas em diferenças (contrariedade, contradição, complementaridade) a partir das rupturas observadas na rede de dependências, de maneira que os limiares ou limites projetados sobre as valências tornam-se fronteiras de uma categoria estabilizada e discretizável. Do mesmo modo, o sujeito sensível, ao se tornar sujeito semionarrativo, vê seu universo partilhar-se axiologicamente graças à polarização em euforia/disforia, enquanto, no espaço tensivo, a foria não polarizada caracteriza as reações de seu corpo próprio às tensões nas quais ele estava mergulhado. Assim, surge o valor no sentido semiótico: o valor como diferença que organiza cognitivamente o mundo focalizado, e o valor como desafio axiológico que polariza o próprio foco. (p. 29)
\end{abstract}

A própria organização do quadrado semiótico está ligada a essa intervenção por parte do operador que torna discretas as categorias sensíveis e contínuas:

Numa espécie de dialética da estabilidade e da instabilidade, a discretização estabiliza as correlações entre as valências, convertendo os limites que elas aceitam em fronteiras de uma categoria; desse modo ela cristaliza as contradições, convertendo respectivamente as valências inversas em contrariedades e as valências conversas em complementaridades. (p. 32)

É essa relação complexa sediada no corpo que Fontanille (2011) associa à operação de junção dos dois planos da linguagem. Segundo nossa leitura, a construção do plano de conteúdo se dá no ato de percepção: a substância de expressão é percebida pelo corpo do sujeito, já previamente disposto à leitura com base em seu conhecimento de mundo, seu arcabouço cultural e seu quadro patêmico; a substância é, assim, formalizada - criam-se relações diferenciais, valores, com base nas valências tensivas e no que Zilberberg e Fontanille (2001) chamam de contexto ${ }^{27}$. O sentido é gerado a partir de um percurso que nasce do ato de discretizar o que é percebido: o sujeito e o objeto precisam diferenciar-se no âmbito da chamada tensividade fórica que se instaura no "acidente perceptivo"; a ruptura engendra uma força tensiva que se complexifica e estabelece oposições semânticas,

\footnotetext{
${ }^{27}$ De acordo com os autores: "A manifestação de uma classe de valores estabelece, para cada valor considerado isoladamente, o seu contexto, mas este último é tratado seja como recurso, seja como um complemento. $\mathrm{O}$ contexto não é um parâmetro secundário, mas primordial e tensivo. Cada grandeza espera, pois, que o contexto fixe a orientação geral do universo de discurso, revelando sua chave axiológica: valores de absoluto ou valores de universo?" (p. 54)
} 
polariza a foria, delineia papéis actanciais por meio de relações lógicas, figurativiza temáticas e, por fim, aspectualiza o discurso. Trata-se de uma relação de troca constante entre corpo e texto, na qual o objeto se constrói para e pelo sujeito ao mesmo tempo em que este se constitui através da construção.

A semiótica tensiva é, portanto, uma semiótica que prioriza as correlações entre valências e a sobredeterminação do sensível (eixo da intensidade) em relação ao inteligível (eixo da extensidade) ${ }^{28}$. Em Zilberberg (2011) delineia-se uma ideia de semiótica "vetorial", por assim dizer, preocupada com o devir, com o discurso em ato, posto que

as grandezas semióticas, as "figuras", na terminologia de Hjelmslev, são, a nosso ver, menos traços do que vetores. Em outras palavras, menos particípios, como passados resolvidos, do que gerúndios, como presentes em devir, em ato. Uma teoria que submete o espaço ao tempo, e o próprio tempo, por sua vez, ao andamento, posiciona-se, por uma questão de coerência, mais sob a égide de Heráclito que sob a de Parmênides... (p. 19)

Os pontos de diálogo com as considerações de Fontanille (2011) a respeito do corpo são constantes na argumentação de Zilberberg (2011), como, por exemplo, no trecho abaixo:

\begin{abstract}
Na perspectiva greimasiana, que - raro feito - concebeu e aplicou uma gramática narrativa eficiente, o fato semiótico que a caracteriza é certamente o programa narrativo. Acreditamos ter demonstrado que a sintaxe fundamental já é narrativa (Zilberberg, 1993a). Tal preeminência, porém, que convém à narrativa e ao conto popular, tendo este historicamente servido de modelo àquela, não satisfaz à chamada semiótica tensiva. Esta se preocupa antes de mais nada com a relação existencial, imediata, imperativa, entre o eu e o não-eu, concebida por Merleau-Ponty na Fenomenologia da Percepção como "uma primeira camada de significação" (ZILBERBERG, 2011, p. 41)
\end{abstract}

Não podemos deixar de ver ecos da noção de identidade encontrada em Fontanille (2011); trata-se, também na abordagem tensiva, de uma preocupação com o estabelecimento de uma semiótica voltada para um sujeito que sente e organiza de modo singular a sua existência sensível.

Testemunho disso é a complexificação do conceito de valência: trata-se da intersecção de um aspecto da foria - que pode ser entendida como "as variações e

\footnotetext{
${ }^{28} \mathrm{Cf}$. Zilberberg (2011, p. 18): "entre as categorias hjelmslevianas e as categorias tensivas, surge um quiasmo, já que as categorias extensas são diretoras para Hjelmslev, quando, na perspectiva tensiva, a intensidade, ou seja, a afetividade, rege a extensidade".
} 
vicissitudes de toda espécie que afetam o sentido" e que "decorrem de sua imersão no 'movente' (Bergson), no instável e imprevisível" (ZILBERBERG, 2011, p. 72) - com uma das subdimensões dos eixos da intensidade/extensidade - o andamento e a tonicidade, no caso do sensível; a espacialidade e a temporalidade, no caso do inteligível -, produzindo, assim, uma pletora valencial (pp. 72-4).

A produção do valor é reconhecida como a associação de duas valências, uma intensa e outra extensa (p. 67), submetidas a um regime de variabilidade (pp. 49-61) baseado na direção, ascendente ou descendente, de sua positividade ou negatividade, por assim dizer; a subdivisão das direções em categorias de atenuação, minimização (relativas à descendência), restabelecimento e recrudescimento (relativas à ascendência) e a análise dessas categorias em unidades como extenuação, saturação etc. - todas elas relacionadas à lógica de oposição entre "pelo menos um" e "mais de um"29 (p. 60) - é, no fim, uma consideração a respeito do aspecto (p. 57) e do ritmo (p. 61) dessas direções da variabilidade valencial. A importância disso pode ser apreendida no trecho a seguir:

\begin{abstract}
Pensemos no motivo ético do perdão, indagando-nos por um instante: qual é o objeto do perdão, o perdoável ou o imperdoável? Qualquer pessoa responderá, sem muita reflexão, pois a reflexão nesse caso é inútil, que o verdadeiro perdão tem por objeto o imperdoável, uma vez que o perdoável já cifra o perdão. Não é difícil catalisar, a partir desse enunciado lapidar - perdoar o imperdoável ,- uma estrutura concessiva e exclamativa: "embora o ato que você cometeu seja absolutamente imperdoável, eu o perdôo!" A modalidade, no âmbito do sujeito - visto que este se empenha, busca seus últimos recursos - e a concessão, no âmbito do processo, estão a nossos olhos ligadas por uma certa conivência. Colocado no espaço tensivo, o motivo do perdão segue, como qualquer outro, a partilha das valências tônicas [...] Rejeitando o jargão [o perdoável seria átono, enquanto o imperdoável, tônico], o senso comum vai direto aos fatos e considera que há, nesse como em tantos outros pontos, "perdão" e "perdão", sendo incomensuráveis os méritos de um (o "sublime" perdão para o imperdoável) e de outro (o "medíocre" perdão para o perdoável). A impossibilidade converte-se na medida do valor modal do perdão. (Idem, p. 65)
\end{abstract}

\footnotetext{
${ }^{29}$ Grosso modo, trata-se de pensar o problema da seguinte forma: a direção ascendente de uma grandeza tensiva é analisável em termos de recrudescimento (uma aumento cada vez maior da positividade) ou restabelecimento (uma diminuição cada vez maior da negatividade), os quais, por sua vez, podem ser analisados em termos de ampliação (acréscimo de uma unidade de positividade) e saturação (acréscimo de mais de uma unidade de positividade), no caso do recrudescimento, ou de retomada (decréscimo de uma unidade de negatividade) e progressão (decréscimo de mais de uma unidade de negatividade). Trata-se de uma diferenciação grande de pontos de vista, em que cada nível revela unidades menores, cuja importância pode variar de acordo com o objetivo da análise.
} 
O valor do perdão é determinado pelo grau de tonicidade ou atonia a ele atribuído, conferindo-lhe aspecto e, de certa forma, ritmo. É esse o campo de ação da semiótica tensiva.

No caso de nosso estudo, a questão da variabilidade valencial é de suma importância. Há, como já demonstrado, uma estrutura narrativa inerente e uma atribuição de valores a elementos que, fora do jogo, seriam percebidos de modo diverso; isso, no entanto, não é suficiente para explicar as diferenças entre modalidades ou as diferenças de uso do corpo em diferentes esportes - a possibilidade de segurar a bola no Basquete e o toque no Vôlei não se explicam apenas por diferentes valores entre os elementos "mão" e "bola", mas na variabilidade de aspecto e ritmo das valências manifestadas a partir deles; é isso que confere identidade a cada jogo, definindo qual tipo de experiência corporal the é característica. A pertinência dessa visada será defendida no tópico a seguir.

\subsection{A visada semiótica no estudo de jogos}

Abrir espaço para uma abordagem tensiva e corporal do jogo implica deslocar o foco do que normalmente se entende como tal -1) o objeto comercializado e oficialmente chamado de jogo; 2) o sistema em si, cristalizado pelos usos; e 3) a partida efetivamente realizada - para observar o fenômeno enunciativo que se baseia em assumir os valores lúdicos do sistema e, assim, converter-se em jogador. A semiótica do jogo precisa ser uma semiótica do ato de jogar, do processo que transforma as virtualidades de um sistema em fenômeno, e isso se mostra adequado por diversos motivos que precisam ser expostos em maior profundidade.

Em primeiro lugar, encarar como objeto de estudo semiótico a partida nos colocaria na posição de análise do produto e não do processo. Trata-se da realização de ao menos parte dos valores virtuais inscritos no sistema e é somente depois de terminada que podemos determinar seu resultado. Como todo jogo permite, mesmo minimamente, o que chamamos de emergência ${ }^{30}$, nenhuma partida de Tênis será exatamente igual à outra e, portanto, nenhuma delas representará $o$ Tênis, mas apenas uma das realizações possível

\footnotetext{
${ }^{30}$ Grosso modo, emergência diz respeito ao fato de que um conjunto restrito de regras pode ser combinado de maneira inusitada gerando padrões não previstos no sistema. No Futebol, por exemplo, as regras permitem que os jogadores passem a bola para outro membro da mesma equipe; da mesma forma, um jogador pode "matar" no peito ou cabecear a bola. Não há, no entanto, uma regra que diga respeito a um passe de cabeça ou a um passe com o peito, porém a jogada é possível, sendo considerada um padrão emergente.
} 
dentre as várias previstas na virtualidade. O estudo semiótico da partida é, portanto, diferente do estudo do jogo e requer diferentes conceitos.

O sistema, por sua vez, enquanto rede de valores virtuais, produz sentido apenas no ato de jogar, evento que possibilita sua atualização e realização. O jogo enquanto não é jogado apresenta potencialidades de sentido, não sentido de fato ${ }^{31}$. O conhecimento das regras e a capacidade de depreendê-las a partir do que chamamos de partida também não configura jogo: assistir ao Futebol ou observar enquanto alguém joga videogame configura, para nós, um tipo diferente de semiose.

O objeto físico, como já dito no Capítulo 1, não pode ser confundido com o jogo da forma como o abordamos; no entanto, há considerações importantes a fazer acerca de sua importância no processo de significação. Tomemos como exemplo Banco Imobiliário, produzido pela empresa Estrela e amplamente comercializado no Brasil. A caixa do produto contém, em sua versão padrão, um tabuleiro com várias marcações, cartas diversas, notas de dinheiro fictício, peões e edificações, bem como um manual com instruções. Nele, há a descrição das regras, sem as quais não é possível jogar, tendo em vista que os elementos na caixa não adquirem valor per se - antes de haver compreensão e aceitação das regras, as peças são apenas peças, isto é, são percebidas de acordo com convenções referentes a outras formas de expressão e, consequentemente, corresponderão a grandezas semióticas de ordem diversa daquela que postulamos para o jogo.

Essa constatação pode gerar a ideia de que o jogo Banco Imobiliário independe das peças encontradas na caixa e existe apenas na virtualidade, podendo ser atualizado e realizado por meio de outra substância; não acreditamos que isso seja possível. Apesar de o conteúdo da caixa não constituir per se o jogo, o sistema está ligado a ele e o requer; caso se perca um peão, por exemplo, é preciso substituí-lo por outro ou então adicionar um elemento similar ao conjunto, pois não é possível jogar banco imobiliário sem um elemento visual que marque a posição. Contudo, nem tudo pode funcionar bem nesse caso: uma peça esférica pode rolar para fora do tabuleiro, assim como um peão de cor igual àquela escolhida por outro participante será inadequado. De modo similar, um dado poderia ser substituído por uma roleta, caso o formato específico não influenciasse nas

\footnotetext{
${ }^{31}$ Assim como um livro não produz sentido guardado na estante e somente em sua leitura as virtualidades ali contidas serão realizadas em um significado - salvo, talvez, se considerado como objeto decorativo, em que ele se torna um elemento visual e deixa de fazer parte de uma semiótica literária.
} 
probabilidades de obtenção de um número. Há, portanto, algum tipo de relação entre a substância e os valores virtuais do sistema.

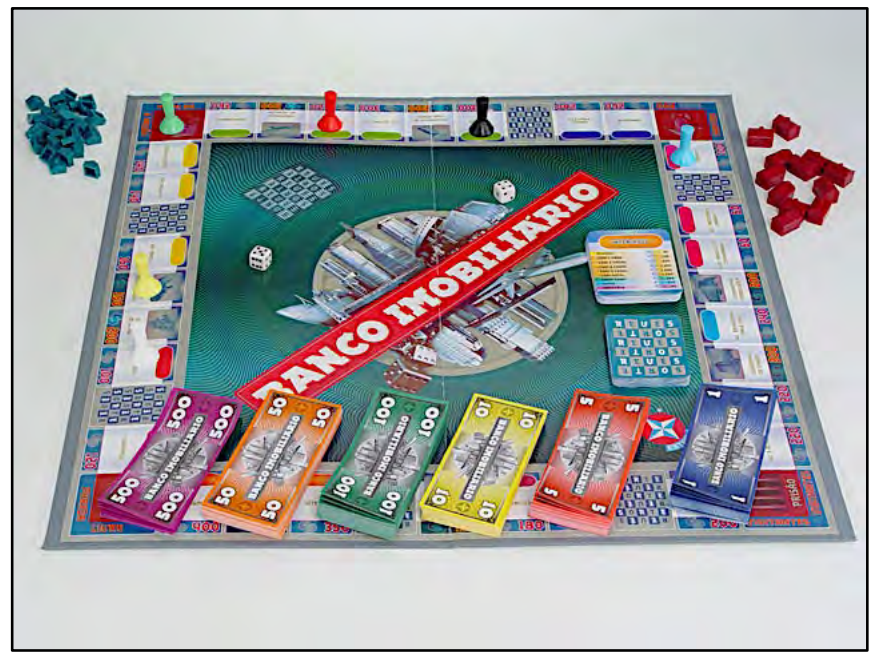

(Figura 4: componentes do jogo Banco Imobiliário)

No entanto, isso não indica que não haja arbitrariedade na constituição do jogo. Chamamos de arbitrária a atribuição de valores ao peão e/ou ao dado no sistema, pois não há relação natural entre a substância e seu valor: em Banco Imobiliário, rolar dois dados com números iguais garantem ao jogador uma nova jogada, porém o mesmo não ocorre em Detetive (Estrela) ou War (Grow) - este, aliás, tem um uso de dados não aliado à movimentação; da mesma forma, é perfeitamente possível que dois peões ocupem o mesmo espaço no tabuleiro em Banco Imobiliário, mas isso é impossível em Detetive e em jogos tradicionais como Ludo, o peão que invade o espaço ocupado pelo de outro jogador obriga-o a voltar para o ponto de partida (popularmente, diríamos que um peão "come" o outro). Apesar de haver usos cristalizados (culturalmente, por vezes), os valores em cada sistema não são óbvios.

Esportes que usam bolas e marcam pontuação são ótimos exemplos não só de arbitrariedade de valores, como também da questão valencial envolvida. Retomando o contraste entre o jogo de Basquete e o de Vôlei, verificamos que o valor do elemento "chão" é bastante distinto; enquanto no primeiro é desejável o contato entre ele e a bola havendo possibilidade de recuperá-la mesmo após o quique -, no último ele é relativizado: caso seja na área reservada ao adversário, é positivo; do contrário, é evitado a todo custo. Além disso, a contagem de pontos é, no Vôlei, diretamente ligada à duração do jogo (o primeiro time a atingir os limites estipulados, ganha), o que muda consideravelmente a percepção por parte dos jogadores de um ponto marcado pelo adversário: cada vez que a 
bola quica de modo desfavorável, o jogo se aproxima do fim; da mesma forma, marcar um ponto quando o adversário está com a vantagem numérica retarda o jogo - há um fator de andamento muito forte na pontuação no jogo de Vôlei (quanto mais acelerado, menor o espaço de tempo do jogo e vice-versa). Isso, aliado à prevalência da tonicidade na formação do valor entre a bola e as mãos - não poder segurá-la implica um controle bastante frágil do fluxo do jogo -, indica uma prevalência quase absoluta da intensidade sobre a extensidade. Já no Basquete, esporte de contato e controle maior do espaço, no qual a marcação de ponto não influi no tempo, há um equilíbrio mais evidente entre sensível e inteligível.

Isso não significa que não possa haver uma partida de Basquete acelerada ou uma desacelerada de Vôlei; trata-se, aqui, de determinar as características valenciais que parecem predominar nas duas atividades. As variações dependem, evidentemente, dos participantes envolvidos, de sua identidade corporal, em suma: fatores como experiência, grau de habilidade, fazem com que as relações entre valências flutuem ao longo da atividade. Para exemplificar, imaginemos uma partida de Vôlei entre um time amador e um profissional; este pode elaborar jogadas extremamente sofisticadas que aumentam consideravelmente a "pressão" e diminuem ainda mais o controle daqueles - o jogo tornase mais intenso para os amadores e mais extenso para os profissionais, caso consideremos, neste caso, a intensidade como a incidência das regras sobre o corpo do sujeito tornando-o mais sensível e menos analítico. O mesmo, evidentemente, pode ocorrer em um jogo de Basquete; porém, como o Vôlei é naturalmente mais intenso que extenso, isto é, abre mais espaço para erros e perda de controle, parece mais fácil para um time profissional de Basquete (jogo com maior equilíbrio entre intensidade e extensidade) dominar um amador, criando jogadas que desestabilizam o adversário e anulam completamente sua capacidade de operar enquanto agentes inteligíveis, do que o é para profissionais de Vôlei - estes, devido à natureza mais intensa do jogo, podem perder o controle do jogo mais facilmente que os de Basquete e, consequentemente, a relação de dominação valencial da extensidade pela intensidade fica fortalecida.

Em nossa leitura, jogar qualquer jogo pela primeira vez é, normalmente, uma experiência mais intensa, enquanto a repetição da atividade diminui a dominância absoluta do eixo sensível sobre o inteligível. É importante salientar que não se trata de uma negação da relação de regência entre os eixos valenciais, mas de uma afirmação da possibilidade de flutuação e variação quando diferentes corpos estão envolvidos no processo de 
significação. Exemplos disso são abundantes, como os casos de tenistas que têm melhor desempenho na quadra de saibro e pior em gramado sintético, ou então pilotos de Fórmula 1, como Ayrton Senna, para os quais a chuva não era necessariamente um problema ${ }^{32}$.

Colocar condições naturais como elementos do sistema pode, em um primeiro momento, parecer despropositado, mas diversos esportes as incorporam nele, enquanto outros criam ambientes isolados para que elas não possam interferir. Se retomarmos o exemplo do Vôlei, a própria realização em uma quadra fechada (que mantém as condições adversas de clima do lado de fora), a qual é limpa várias vezes durante o evento (para manter o atrito ideal), é evidência de que todos esses fatores são importantes, caso contrário não haveria esforço para controlá-los. No Tênis, a plateia deve permanecer calada para não atrapalhar a concentração dos jogadores e a partida é suspensa em caso de chuva; todavia a luz do sol é integrada ao sistema: os jogadores devem trocar de lado na quadra regularmente para que a adversidade perceptiva causada pela luz nos olhos seja dividida entre eles. Um jogador experiente de tênis deve, evidentemente, saber aproveitar os momentos em que o adversário se encontra em situação de desvantagem, ao passo que deve adotar outras estratégias de jogo quando em situação desfavorável. Os jogadores de Golfe encontram-se em situação similar em relação ao vento e aos diversos tipos de terreno presentes no campo, os quais podem ser utilizados para ganhar vantagem ou devem ser estudados de modo a mitigar possíveis obstáculos.

Como aponta Juul (2005), as versões digitais de esportes simulam aspectos naturais. A solução mais frequente em jogos de Tênis é posicionar a câmera do jogo atrás de um dos lados da quadra, deixando-o mais próximo e, portanto, mais visível, enquanto o outro fica mais distante (Figuras 5 e 6); a troca de lados cria dificuldades para quem se encontra mais ao fundo da tela e, consequentemente, facilita o jogo para aquele que está mais próximo. A perspectiva da câmera funciona como analogia à luz do sol, no caso.

\footnotetext{
32 Cf. http://veja.abril.com.br/blog/10-mais/esporte/os-10-feitos-que-transformaram-senna-em-mito-da-
} formula-1/ (Acesso em 14/10/2014) 


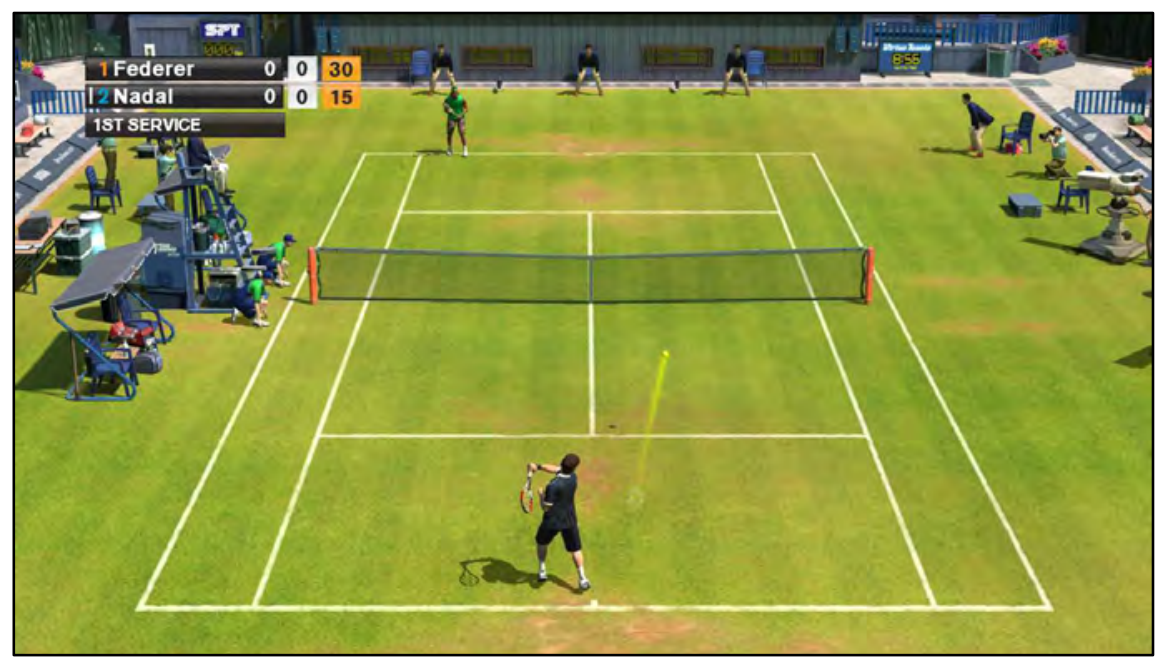

(Figura 5: Virtua Tennis (Sega, 2009))

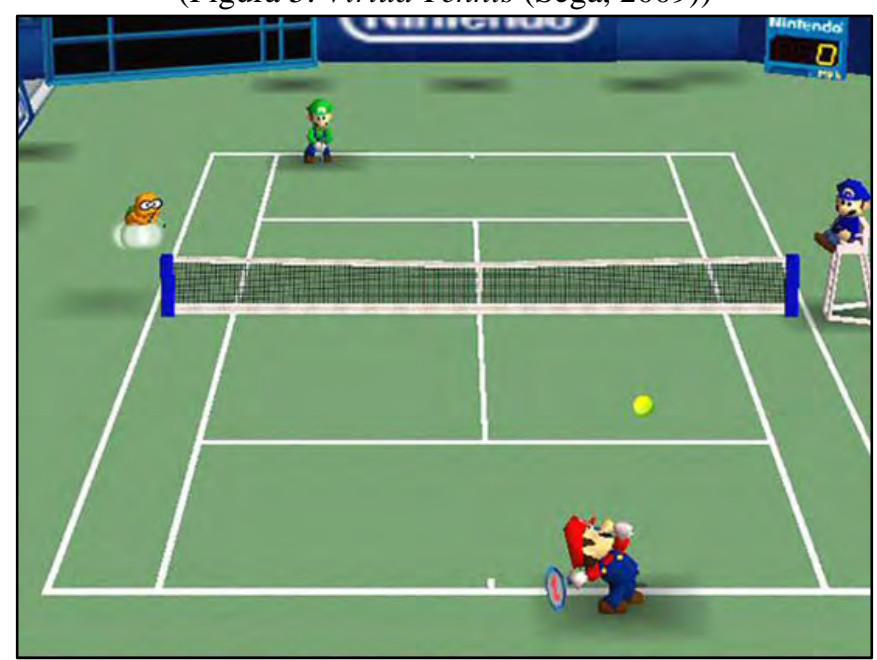

(Figura 6: Mario Tennis (Nintendo/Camelot, 2000))

Esse tipo de simulação é evidência de que o natural pode receber valores no sistema, e está, portanto, longe de representar apenas uma tentativa de alcançar o hiperrealismo enquanto estética. Fosse esse o caso, encontraríamos em jogos digitais de Tênis partidas interrompidas por chuva ou então a necessidade de acalmar a plateia - situações possíveis na versão não digital do esporte, como já mencionamos, mas que não estão integradas em seu sistema e, consequentemente, atrapalham seu desenvolvimento.

Interferências no sistema podem ocorrer em qualquer modalidade de jogo, gerando inquietação. Uma lesão séria, um confronto antidesportivo, equipamentos mal regulados são comuns em competições; mesmo jogando-se Xadrez em casa é possível haver um telefone tocando, uma distração qualquer que faça os jogadores esquecerem quem fez o último movimento ou algo do tipo. Em jogos de tabuleiro que fazem uso de dados, estes podem cair no chão ou até mesmo derrubar as demais peças do tabuleiro. No caso dos jogos digitais, joysticks, aparelhos de TV e periféricos de computador podem apresentar 
problemas; uma queda de energia elétrica ou de sinal de internet podem acabar com uma partida e assim por diante. As interferências da carne e do ambiente são várias e extremamente variadas, mas o que precisa ser ressaltado aqui é que um elemento natural que interrompe uma partida de Tênis é bem-vindo e integrado ao Futebol ou à Corrida de Fórmula 1, o que indica sua sistematização e possibilidade de uso estratégico por parte dos jogadores da atividade lúdica. A condição de limiar é, portanto, intrínseca ao jogo e tanto as interferências do corpo-carne quanto do ambiente que engloba o ficcional precisam ser levadas em conta na medida em que podem fazer parte do sistema.

Em alguns casos, a situação de limiar gerada pela interferência do corpo-carne é o que garante a manutenção de um jogo. Juul (2005) menciona como exemplo o Jogo da Velha, em que o conhecimento extensivo do conjunto de regras leva à formação de um oponente invencível ou a uma série de empates sucessivos. Os jogadores se integram de tal forma ao sistema que, sem os possíveis lapsos ou a permanência de algum traço dos simulacros alheios ao corpo-lúdico - como, por exemplo, o do pai ou mãe que "alivie a barra" para que a criança tenha chances de ganhar -, o jogo torna-se impossível; um jogador que não comete erros assemelha-se a um oponente computadorizado sem restrições de programação, capaz de prever qualquer movimento e executar os próprios sem falhas. A impossibilidade de integração total com o sistema, isto é, de resistência da carne, garante a individualidade dos participantes - como já apontado na citação de Fontanille (2011, p. 19) - e a própria existência do jogo, na medida em que é preciso haver dúvida a respeito do resultado para que a atividade seja considerada prazerosa.

Essas questões tornam-se mais complexas quando o assunto envereda para os jogos digitais, por dois motivos básicos: 1) o sistema de regras é auto-suficiente e retroalimentativo; e 2) o engajamento na atividade lúdica parece obrigatório - como se fosse impossível não seguir as regras de um ambiente virtual programado, gerando sempre uma situação de jogo a cada vez que se entra no mundo digital. Trata-se, no entanto, de um processo similar ao dos jogos de tabuleiro e dos esportes, mas que precisa de uma abordagem específica, discutida no próximo tópico.

\subsection{O componente lúdico dos jogos digitais}

Jogos digitais caracterizam-se por sua condição evidente de objetos de limiar: ao mesmo tempo em que são jogados por meio de aparelhos físicos (computadores, consoles, 
tablets, smartphones), as ações do jogador refletem-se em um ambiente digital e programado que muitas vezes excede os limites físicos do aparelho - em Super Mario World (Nintendo, 1991), ao movimentar-se até determinado ponto do cenário, a tela "corre", demonstrando que há mais para se ver do que o enquadramento do painel consegue abarcar. Há, portanto, uma expansão do físico por meio do virtual ${ }^{33}$.

A relação entre os dois campos muitas vezes funciona por "tradução" (um toque no botão converte-se em movimento, pausa, acesso a um menu etc.) e nem sempre as relações entre aparelho e ambiente são óbvias; embora seja quase intuitivo que o movimento de uma alavanca para a esquerda ou direita represente uma movimentação de algum elemento virtual, o uso de botões é muito menos óbvio, tornando necessárias explicações ou séries de tentativa e erro para que se aprenda a operar o aparelho.

Isso, evidentemente, diz respeito à questão da arbitrariedade inerente a um sistema e aproxima o jogo digital dos exemplos previamente citados; ao mesmo tempo, esse atributo gera afastamento: havendo apenas uma ação programada para o botão, torna-se extremamente difícil operar de maneira não prevista. Se considerarmos que é perfeitamente possível pegar as cédulas de Banco Imobiliário e dobrá-las em forma de avião de papel, amassá-las ou até mesmo modificar seu valor, é impossível fazer com que o Mario dance ou que as tartarugas inimigas não o façam encolher caso se encoste nelas ${ }^{34}$. As regras do sistema são fixas e dizem respeito a muito mais do que as permissões e proibições ao jogador; o ambiente em si mesmo é organizado e funciona a partir de regras e há todo um comportamento que precisa ser depreendido para que se possa jogar. Isso ocorre pois uma característica intrínseca de um ambiente digital é sua proceduralidade, termo retirado de Murray (1997) e que dá conta da arquitetura de procedimentos (procedures) programados ${ }^{35}$.

Há aspectos procedurais em diversos jogos de tabuleiro: em Jogo da Vida (Estrela), por exemplo, toda vez que se passa por uma casa vermelha denominada "Dia de Pagamento", recebe-se uma quantia em dinheiro de acordo com sua profissão no jogo; em Banco Imobiliário, uma quantia - estipulada nas regras - é recebida ao passar pelo ponto inicial do tabuleiro. No entanto, é preciso que os participantes fiquem atentos aos gatilhos ${ }^{36}$

\footnotetext{
${ }^{33}$ Termo aqui empregado em seu sentido corrente e não na acepção da teoria semiótica greimasiana.

${ }^{34}$ Desconsideramos aqui os resultados obtidos quando o sistema é hackeado.

${ }^{35}$ Voltaremos com maior vagar a essa definição no Capítulo 3.

${ }^{36}$ Do inglês trigger, é um termo técnico de programação de ambientes digitais e refere-se ao elemento que desencadeia um procedimento.
} 
dos procedimentos para que eles sejam efetivamente realizados. Bem diferente é o caso dos jogos digitais, pois o sistema se retro-alimenta após iniciado e faz com que os gatilhos ativem-se automaticamente quando as condições são preenchidas: em Super Mario 64 (Nintendo, 1996), quando o jogador faz com que Mario se mova por uma área texturizada para aparentar gelo, a personagem passa a deslizar. Outro exemplo de procedimento existente em um jogo digital pode ser visto na situação de um abismo sobre o qual flutuam diversas plataformas moventes; caso o jogador desloque a personagem na direção do abismo, haverá queda e, consequentemente, uma derrota - cabe a ele descobrir qual o padrão de movimento de cada plataforma para executar os saltos necessários e, assim, atravessar o abismo. Por vezes as plataformas destroem-se quando a personagem controlada pelo jogador - ou até mesmo pelo próprio sistema (os inimigos que frequentemente precisam ser eliminados) - passa muito tempo sobre elas, exigindo ainda mais destreza na travessia. Nenhum dos procedimentos descritos acima depende da vontade do jogador para sua ativação: o gatilho de destruição da plataforma ativa-se automaticamente quando o limite de tempo programado é atingido, assim como os gatilhos de deslizamento são acionados no momento em que a personagem entra na área de efeito estipulada.

Nesse aspecto os procedimentos são bastante parecidos com as condições naturais e as leis da física presentes nos esportes: são procedimentos que incidem sobre o corpo do sujeito independentemente de sua vontade - assim como a água da chuva não pergunta aos jogadores se desejam ou não que se altere o atrito com o gramado, Mario encolhe ao encostar em uma tartarugas sem dar satisfações a quem segura o joystick. Esses atributos, no entanto, dizem muito pouco sobre o jogo na medida em que são relativos à constituição do ciberespaço e se encontram presentes nos mais diversos objetos digitais, desde websites até obras literárias hipermidiáticas.

Além disso, nossa constatação de que as regras precisam ser assumidas por um sujeito mostra-se pertinente até mesmo nos ambientes digitais, devido ao fato de um jogador poder tentar ignorá-las e "subverter" o sistema utilizando-o para fins que não os propostos pelos desenvolvedores (o destinador pressuposto, no caso): é possível usar o ambiente digital de Tetris para criar formas diversas com as peças que surgem da parte superior - o programa torna-se um suporte para "desenhar" ${ }^{37}$; de modo similar, uma prática bastante comum em jogos como Driver 2 (Infogrames, 2000) ou Grand Theft Auto: Vice

\footnotetext{
${ }^{37}$ http://www.neatorama.com/2013/06/04/Drawing-With-Tetris/\#!BeYJw (acesso em 14/10/2014)
} 
City (Rockstar, 2002) é ignorar as missões e desafios propostos pelo jogo para "passear" pelo ambiente sem um objetivo que vá além da pura experiência de exploração. Segundo Murray (1997, p. 98), isso está ligado ao prazer intrínseco de navegar por um ambiente simulado, como é o caso do ciberespaço. Voltaremos a esse assunto com maior vagar no Capítulo 3.

O importante neste momento é a constatação de que o fator que define um jogo enquanto objeto transmidiático é a espécie de conversão identitária requerida pela atividade: aceitar a imposição das regras e procedimentos estabelecidos é o primeiro passo para tornar-se um jogador. Isso se dá de diversas maneiras, a depender do jogo, e gera questões específicas caso a caso. Se considerarmos os esportes que exigem proeza física, como o atletismo, notamos que a conversão incide sobre a carne de modo global os membros e o sistema respiratório são extenuados, por exemplo; em casos como o Tênis, exige-se uma extensão do corpo por meio de um instrumento - a raquete funciona como um braço protético; e, por fim, na Fórmula 1 ou Nascar, vemos uma "fusão" entre homem e máquina.

Jogos de tabuleiro, como Banco Imobiliário ou Xadrez, operam uma divisão de corpo, na medida em que o sujeito, além de usar a própria carne para realizar algumas tarefas, vê-se representado no espaço demarcado por avatar(es). Seja de modo concentrado ou difuso, a presença no tabuleiro é da ordem da representação, muitas vezes simbólica, do ato: perde-se (ou ganha-se) uma peça, uma posição ("volte duas casas"), a liberdade de movimento ("fique preso por três rodadas"), tudo isso em relação aos avatares - a integridade da carne do jogador permanece intacta.

Nos jogos digitais, ocorre uma espécie de mistura dos processos relativos ao corpo: os controles do aparelho, sejam eles quais for, permitem que se manipulem os elementos do jogo e/ou os avatares como com cordas de marionete; há evidentemente uma transferência simbólica, na medida em que os procedimentos incidem sobre o corpo virtual, porém as tecnologias atuais permitem uma ligação mais forte entre avatar e jogador (joysticks com vibração, emissão de sons localizados, dispositivos de captura de movimento etc.) que atenuam a linha que separa os dois corpos - uma espécie de enfraquecimento da "quarta parede"; e, por fim, há o apego emocional-psicológico com o 
avatar, responsável muitas vezes pelo emprego da primeira pessoa em referência a ele diz-se "caí no buraco" ou "morri" quando Mario cai ou é derrotado. ${ }^{38}$

Ainda mais complexa é a associação identitária quando o avatar a que o jogador se liga corresponde a uma personagem central de um enredo elaborado. À parte da estrutura narrativa inerente ao jogo, há cada vez mais a ideia de que é preciso contar uma história, desenvolver um problema narrativo ou então possibilitar um ambiente de interação multijogador com o que se chama de lore - um pano de fundo e um grupo de conhecimentos que deem coerência aos elementos temáticos e figurativos encontrados no ambiente digital. Há, portanto, outro limiar, dessa vez centrado no avatar: além de corresponder à figurativização do actante-sujeito da estrutura narrativa do jogo, ele está ligado àquela do enredo; da mesma forma, o jogador, por sua relação com o avatar, comanda o papel temático de herói de uma história que, apesar de muitas vezes ter um desenvolvimento fixo, se desenrola no e pelo ato de jogar - é uma relação complexa (a cujos entraves no campo da ludologia já aludimos no Capítulo 1) e que carece de um desenvolvimento teórico profundo, o qual ultrapassaria os limites de uma dissertação; algumas linhas gerais e um questionamento voltado aos problemas específicos dos jogos feitos para um jogador são o tema do Capítulo 3 deste trabalho.

\footnotetext{
${ }^{38}$ Cada jogo prioriza um aspecto diferente da questão do corpo. Jogar Tetris em um aparelho próprio pra isso ou Fruit Ninja (Halfbrick, 2010) em smartphone é muito mais parecido com a experiência de utilizar um brinquedo como o Aquaplay (Estrela, não digital), em que não se pode falar de avatar. Não se trata, aqui, de estabelecer categorias absolutas, sobretudo devido ao fato de as tecnologias apresentarem modificações constantes.
} 


\section{Capítulo 3}

\section{O jogo digital e sua complexidade narrativa}

No Capítulo 2, defendemos a ideia de que a estrutura básica de um jogo pode ser explicada de acordo com um esquema narrativo básico, tal qual apresentado pela semiótica francesa: um sujeito (jogador) realiza uma performance (a partida) com base em um conjunto de valores advindos de um destinador (as regras) tendo como objetivo a aquisição de um objeto-valor e a sanção positiva do destinador (a vitória em conformidade com o regulamento). Em se tratando de um princípio geral, é evidente que pode ser aplicado a qualquer jogo, indicando que a narratividade é inerente ao ato de jogar; apesar disso, essa constatação não é per se suficiente para caracterizar um estudo semiótico tendo em vista não só que o complexo tensivo existente no ato de percepção do corpo próprio do sujeito como elemento de um sistema regrado é o elemento responsável tanto pela significação do evento em uma instância específica quanto pelas diferenças entre os mais diversos jogos, mas também que essa constatação acerca da narratividade inerente ao ato de jogar pode ser aplicada a todo e qualquer objeto de sentido, tendo em vista que a narrativização da experiência sensível é basilar para a noção de significação da semiótica francesa. Em suma, é de certa maneira redundante afirmar que algo específico tem uma estrutura narrativa inerente quando a nossa percepção de todo e qualquer objeto é em si uma narrativização ${ }^{39}$.

Evidentemente, quando se trata de um objeto considerado artístico como um romance ou filme, a narratividade é óbvia; no entanto, a ideia de estruturação narrativa da significação se sustenta mesmo em casos cuja banalidade ou abstração impedem qualquer relação evidente com as acepções mais corriqueiras do termo. Pensemos, por exemplo, em uma lata de refrigerante amassada deixada em uma mesa de praça de alimentação; parece óbvio que o refrigerante foi tomado por alguém e que a lata não foi jogada fora. Nessa breve constatação observamos imediatamente duas estruturas de performance, uma realizada e outra não realizada: no primeiro caso, podemos pressupor que um sujeito, cuja

\footnotetext{
${ }^{39} \mathrm{O}$ processo de significação metaforizado no Capítulo 2 é, de acordo com a semiótica de linha francesa, estruturado de acordo com categorias lógico-narrativas, como bem demonstra o nível intermediário do percurso gerativo do sentido.
} 
competência modal estava completa na medida em que ele quis (ou achou que devia), soube e pôde fazer, realizou uma performance envolvendo um objeto de valor (matar a sede, por exemplo); no segundo, vemos que esse mesmo sujeito, apesar de dever, saber e poder fazer, não realizou a performance envolvendo o objeto (não jogou a lata no lixo, no caso). Essa estruturação aparentemente despropositada corresponde ao processo de racionalização da experiência sensível de observar um dado qualquer para chegar a uma conclusão interpretativa e, por vezes, a um julgamento moral - a noção de que a lata foi impropriamente deixada na mesa deriva da não conformidade esperada entre o sujeito pressuposto em nossa pequena história e um universo de valores em que conceitos como higiene, limpeza, consciência ambiental e social (no caso, poder-se-ia pensar que os funcionários responsáveis pela praça de alimentação não são obrigados a recolher o lixo deixado pelos usuários) são euforizados. Outro exemplo pode ser encontrado na inquietação gerada por artistas modernos como Duchamp ou Mondrian; o não entendimento da suposta mensagem contida em suas obras também corresponde à avaliação de uma não adequação a um conjunto de valores pré-estabelecido e pressuposto: um vaso sanitário ou urinol deve não ser exposto e chamado de arte, não podendo ser considerado um objeto de contemplação, e, assim, o trabalho é negativamente sancionado como incoerente ou não artístico; no caso de Mondrian, podemos pensar no choque com sistemas de valores em que a representação em pintura é eufórica ou que estabelecem a dificuldade como critério, gerando "críticas" formuladas em sentenças como "qualquer criança seria capaz de fazer isso" ou "não é possível entender o que está retratado". Em suma, trata-se de compreender que a experiência sensível é trabalhada de modo narrativo ao se atribuir papéis actanciais aos mais diversos objetos e situações com as quais nos deparamos cotidianamente.

Isso não significa, no entanto, que essa estruturação básica corresponderá, na superfície, àquilo que chamaríamos de enredo: apesar de ser possível narrar uma partida de Futebol ou de elaborar uma sequência de estados que deem coerência à lata encontrada na mesa, dificilmente consideraríamos o resultado dessa racionalização uma história comparável a um longa metragem, uma peça teatral ou a um romance - com efeito, há um abismo entre ler a descrição da semifinal entre Brasil e Alemanha na Copa do Mundo de 2014 e Os Miseráveis de Victor Hugo. O mesmo princípio poderia ser aplicado a romances e filmes baseados em fatos reais: os acontecimentos em si mesmos, tal como relatados em um jornal ou até mesmo quando presenciados diante dos olhos, têm certamente uma 
estrutura narrativa, porém meramente relatá-los em ordem cronológica não constitui o que se chama de "boa história". De fato, há algo de específico no que toca ao enredo e que não se resume à narratividade (apesar de contê-la), o que torna muitas vezes bastante complexa a estruturação de enredos em forma de jogo; é certo que todo jogo pode ser narrado, mas é algo totalmente diferente pensá-lo como uma forma que narra.

O objetivo deste capítulo é investigar a questão complexa envolvida no casamento entre o jogo e o contar histórias ${ }^{40}$, atividades cujo estatuto narrativo é bastante distinto, mas não oposto como as conclusões de Ranhel (2009), a que aludimos no primeiro capítulo, dão a entender. Para maior clareza, o início de nosso percurso de investigação deve centrar-se não no jogo, mas naquilo que chamamos de enredo e nos diversos modos de trabalhá-lo em formas expressivas diferentes.

\subsection{Os problemas da noção tradicional de enredo no campo dos jogos digitais}

Em teoria literária, o termo enredo designa a organização de um determinado assunto ou tema em uma forma causal e não necessariamente cronológica; não se trata, portanto, da matéria efetivamente narrada, designada por fábula. Essa divisão parece ser suficiente para postularmos que determinada sequência de eventos narrativos pode ser organizada em mais de um tipo de enredo. Essa noção pode ser aproximada daquilo que Aristóteles designa por mito em sua Poética: determinada matéria narrativa trabalhada e organizada de acordo com o gênero. Há, portanto, uma distinção teórica bastante clara entre $o$ que se narra e como se narra, sendo este o domínio da chamada arte narrativa.

A busca do modo mais adequado de organizar conteúdos narrativos quaisquer que sejam é, em grande parte, um desafio que se impõe a qualquer forma expressiva cujo ato seja o narrar. Acerca disso, Murray (1997) afirma:

\footnotetext{
In 1455, Gutenberg invented the printing press - but not the book as we know it. Books printed before 1501 are called incunabula; the word is derived from the Latin for swaddling clothes and is used to indicate that these books are the work of a technology still in its fancy. It took fifty years of experimentation and more to stablish such conventions as legible typefaces and proof sheet corrections; page numbering and paragraphing; and title pages, prefaces, and chapter divisions, which together made the
}

\footnotetext{
${ }^{40}$ A palavra storytelling na língua inglesa expressa bem a diferença que estamos apontando.
} 
published book a coherent means of communication. [...] Similarly, new narrative traditions do not arise out of the blue. A particular technology of communication - the printing press, the movie camera, the radio - may startle us when it first arrives on the scene, but the traditions of storytelling are continuous and feed into one another both in content and in form. (p. 28)

Como resultado, podemos entender que determinado gênero de certa maneira limita as possibilidades de enredo, como indica Ernica (2014):

a divisão em capítulos era uma exigência imposta aos romances folhetinescos pelas próprias condições específicas de produção e circulação dos textos literários no século XIX; o uso de desfechos impactantes ou misteriosos no final de cada capítulo servia à necessidade de manter o leitor curioso e atento à trama, para que evidentemente continuasse a acompanhar a obra. Nos dias atuais, os livros não são mais vendidos "aos pedaços", mas a organização em capítulos segue moldes parecidos e, portanto, o conteúdo também é estruturado de modo similar: há um estilo romanesco de escrever e os leitores esperam que os romances sejam escritos de uma determinada maneira, e não de outra como bem demonstra o sucesso comercial de romances como $O$ Código Da Vinci, de Dan Brown. Isso é o que Achcar denomina, a partir do termo "composição genérica" de Francis Cairns, "codificação da prática intertextual", definida como "uma forma particular de 'arte alusiva': um poema toma do repertório tradicional uma série de lugares-comuns e, juntamente, a maneira de organizá-los, derivando daí sua pertinência genérica." (p. 18) O gênero, sobretudo na prática letrada anterior ao século XIX, é a chave de leitura principal para qualquer texto. (p. 59)

A organização de enredo, portanto, concerne ao que se chama de plano de expressão; é um modo de apresentação específico de elementos que contêm informações narrativas.

O conceito de informação narrativa apresentado em Ernica (2014) diz respeito à interpretação de narratividade a que aludimos na introdução deste capítulo. Retomando o exemplo da lata de refrigerante, elementos visuais como o amassado na lata carregam tanto as informações de performance realizada, caso o foco seja no ato de beber, quanto as de não realizada, ação de jogar fora; em suma, há "indícios", "marcas" de narratividade no plano de expressão. Criar um enredo consiste em organizar artificialmente os mais diversos elementos expressivos de modo a estabelecer um complexo narrativo particular, uma espécie de direcionamento da percepção, o qual, por sua vez, desencadeia um processo de significação em que os parâmetros de interpretação narrativa encontram-se dados previamente pelos elementos perceptivos - grosso modo, é uma tentativa de induzir a determinadas deduções de sentido.

Isso não significa, no entanto, que o propósito de um enredo seja o de criar uma interpretação unívoca e definitiva. Muitas vezes, o propósito é justamente o contrário; 
escritoras como Clarice Lispector fiam-se nos atributos da linguagem verbal para criar ambiguidades, múltiplas interpretações e até mesmo a sensação de vazio ou confusão. É o caso do conto "Preciosidade", do livro Laços de Família, em que a protagonista é, em seu ponto de vista, violentada e maculada por dois rapazes. Não fica claro se houve agressão, alguma forma de estupro ou um mero toque, porém isso pouco importa para o desenvolvimento do conto; a ideia é justamente borrar a capacidade do leitor em inteligibilizar o evento, deixando todo o peso no campo do sensível e, mais importante, em como a personagem o sente. Trata-se, em suma, de uma desordem organizada e isso é, em nossa definição, trabalho de enredo ${ }^{41}$.

Tendo isso em vista, é preciso estabelecer quais são as estratégias de produção de enredo nos jogos digitais antes de mergulhar efetivamente na análise de qualquer caso específico. Para isso, examinaremos as considerações de Murray (1997) e Santaella (2004) acerca do ciberespaço de modo a verificar quais conceitos são utilizados pelos desenvolvedores nos mais diversos jogos que têm como intuito o narrar.

\section{As características do ciberespaço}

Dedicada a estudar o ciberespaço como um meio capaz de contar histórias, Murray (1997) aponta que é preciso refletir sobre suas características intrínsecas apara que se possa estudá-lo de modo independente; a autora aponta vários exemplos de tentativas de utilização do ciberespaço para essa finalidade, mas diversas delas apenas fazem uma "colagem" de elementos multimídia sem atentar para as características do meio.

Dentre os elementos da estética dos ambientes digitais, Murray dá destaque aos três a seguir, que não são exclusivos, mas encontram-se neles intensificados: a imersão, a agência e a transformação. Apesar de a autora consagrar um capítulo para cada um dos conceitos, cremos que eles não possam ser entendidos adequadamente quando considerados isoladamente, portanto faremos aqui uma apreciação comparativa.

Acerca do conceito de imersão, a autora afirma o seguinte:

A stirring narrative in any medium can be experienced as a virtual reality because our brains are programmed to tune into stories with an intensity that can obliterate the world around us. (p. 98)

\footnotetext{
${ }^{41}$ Processo similar pode ser verificado no filme Cisne Negro (2010), em que não se sabe onde começam e terminam os delírios da protagonista em seu percurso de transformação de cisne branco em cisne negro.
} 
O diferencial do ciberespaço nesse quesito reside não só na quantidade enorme de detalhes e recursos visuais utilizados na criação de um ambiente, como também na sensação de participação: "With encyclopedic detail and navigable spaces, the computer can provide a specific location for places we long to visit. [...] Unlike Don Quixote's books, digital media take us to a place where we can act out our fantasies." (Ibidem) Mais além: "we enjoy the movement out of our familiar world, the feeling of alertness that comes from being in this new place, and the delight that comes from learning to move within it." (pp. 98-99) Não se trata somente de estar imerso, mas da possibilidade de um fazer, ligado ao que Murray conceitua como agência:

\footnotetext{
Agency is the satisfying power to take meaningful action and see the results of our decisions and choices. We expect to feel agency on the computer when we double-click on a file and see it open before us or when we enter numbers in a spreadsheet and see the totals readjust. However, we do not usually expect to experience agency within a narrative environment. (p. 126)
}

Note-se que o fazer é sempre definido em seus efeitos: clica-se na pasta e ela abre; é preciso, portanto, que as ações tenham (ou ao menos pareçam ter) um resultado palpável no ambiente digital, transformando-o de certa maneira. Essa ideia de transformação corresponde, de um ponto de vista sistêmico, à recombinação de elementos de várias formas com a possibilidade de resultados diversos. Em suma, a base da linguagem do ciberespaço é metamórfica, estruturada em "arquiteturas líquidas da informação, arquiteturas com arestas macias, fluidas, tão intercomunicantes quanto as sinapses das redes neuronais" (Santaella, 2004, p. 51).

A palavra "arquitetura" é bastante usada por Santaella, na medida em que o tipo de leitura exigida pelo ciberespaço é, segundo a autora defende, imersiva, baseada na navegação por nós:

Em vez de um fluxo linear de texto como é próprio da linguagem verbal impressa, no livro particularmente, o hipertexto quebra essa linearidade em unidades ou módulos de informação, consistindo de partes ou fragmentos de textos. Nós e nexos associativos são os tijolos básicos de sua construção. Os nós são as unidades básicas de informação em um hipertexto. (Idem, p. 49)

A diferença entre hipertexto e hipermídia reside no sincretismo presentes nos nós: 
Um nó pode ser um capítulo, uma seção, uma tabela, uma nota de rodapé, uma coreografia imagética, um vídeo ou qualquer outra subestrutura do documento. É muito justamente a combinação de hipertexto com multimídias, multilinguagens, chamando-se de hipermídia. (Ibidem)

Consideramos que a ideia de transformação proposta por Murray depende dessa noção de hipermídia, na medida em que cada acesso ao ciberespaço vai recombinar os nós e organizar as informações de maneira singular, caleidoscópica em contraste, por exemplo, com o modelo de mosaico instaurado pelo jornal e pelo cinema (MURRAY, 1997, pp. 1601). O mundo digital requer, dada sua estrutura, um tipo diferente de leitura e de autoria, como apontam Murray e Santaella - ambos os livros são dedicados para lançar as bases dessas novas competências. De acordo com a primeira, esse novo tipo de abordagem é procedural, termo a que já aludimos no Capítulo 2.

Não se pretende aqui esgotar esse conceito, mas estabelecer algumas linhas interpretativas gerais que nos permitam relacioná-lo à questão do jogo enquanto forma de narrar. Grosso modo, a ideia de autoria procedural diz respeito à tradução de conceitos narrativos em forma de uma experiência regrada; trata-se da criação de algum ambiente (digital, no caso) cujo funcionamento encontra-se programado e que o usuário poderá explorar de alguma maneira. As informações narrativas devem ser codificadas nos mais diversos aspectos do sistema, sejam eles botões de comando, situações que se apresentam e exigem algum tipo de solução, comportamento de elementos (personagens, estruturas mecânicas etc.), e serão depreendidas pelo usuário ao longo da visita. Em suma, em vez de apresentar um enredo organizado, o ciberespaço cria uma vivência narrativa a partir da qual se pode extrair algum tipo de conteúdo. Nas palavras de Murray, "electronic closure occurs when a work's structure, though not its plot, is understood" (p. 174).

Ernica (2014, pp. 61-2) se refere a essa sensação de "saciedade" narrativa por meio do termo saturação, emprestado da sintaxe. Essa analogia com a estrutura argumental de uma sentença é frutífera na medida em que, como vimos, o processo de significação tal qual descrito pela semiótica francesa consiste na inteligibilização de uma experiência sensível em termos de relações lógico-formais entre categorias narrativas; ou seja, a saturação provém da criação cognitiva de uma ordo a chao, uma ou mais linhas narrativas que dão algum tipo de coerência à experiência, mesmo que se trate de algo como a desordem organizada a que aludimos anteriormente ${ }^{42}$.

\footnotetext{
${ }^{42}$ Cf. Ernica (2014) para uma exposição dos efeitos de sentido da incompletude narrativa.
} 
Em caráter de exemplo, analisemos brevemente o caso de Dear Esther, um "jogo" projetado por um grupo independente de designers e que utiliza uma game engine ${ }^{43}$ para criar uma experiência narrativa. Para avançar na compreensão da história, deve-se explorar uma ilha e deixar-se levar pela experiência imersiva; em alguns momentos, uma voz começa a narrar um evento qualquer e caixas de texto surgem revelando algum dado.

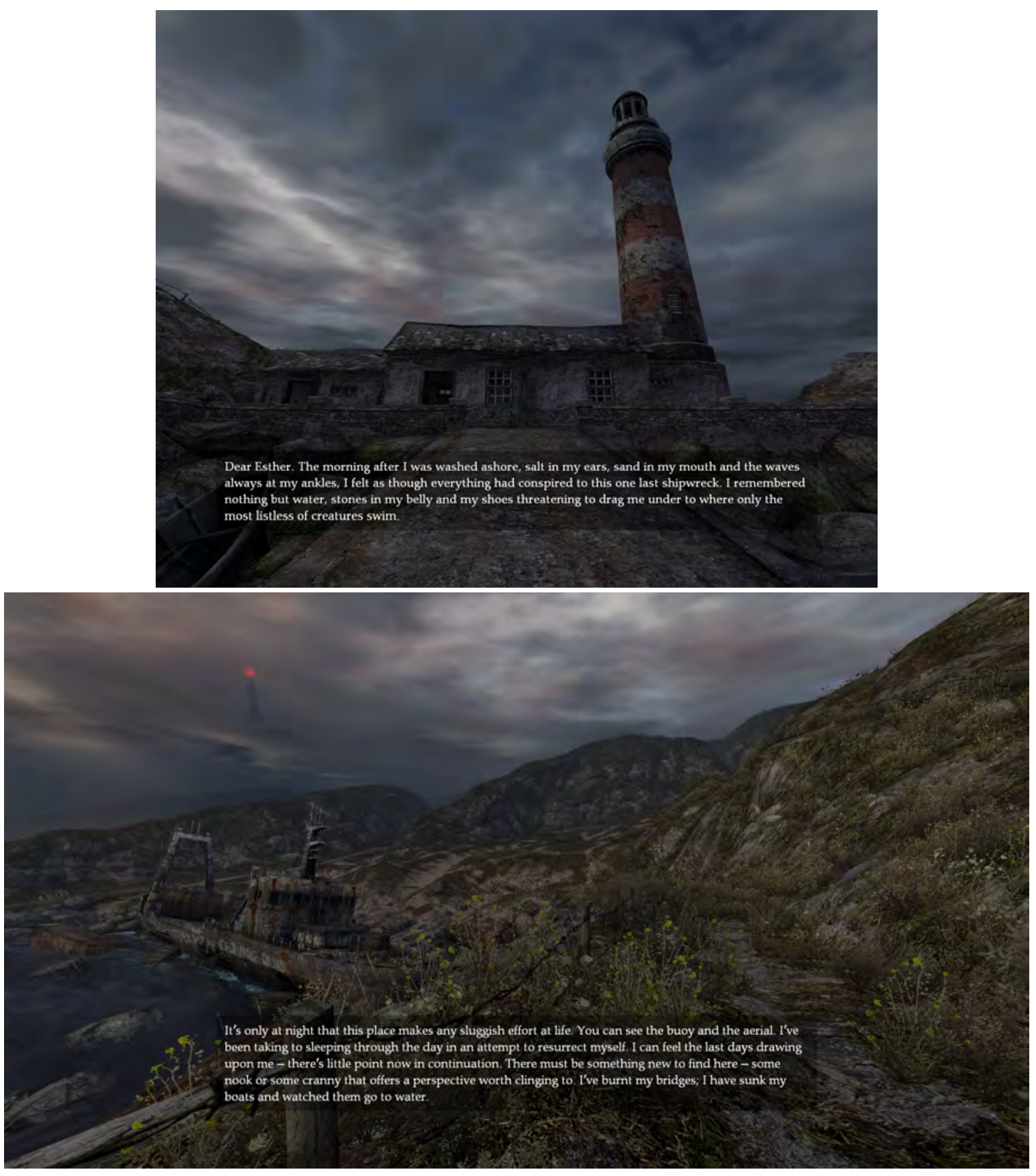

\footnotetext{
${ }^{43}$ Grosso modo, é o nome dado ao programa que faz o jogo funcionar. É onde será programada a física artificial, definidas as relações entre os elementos gráficos etc.
} 


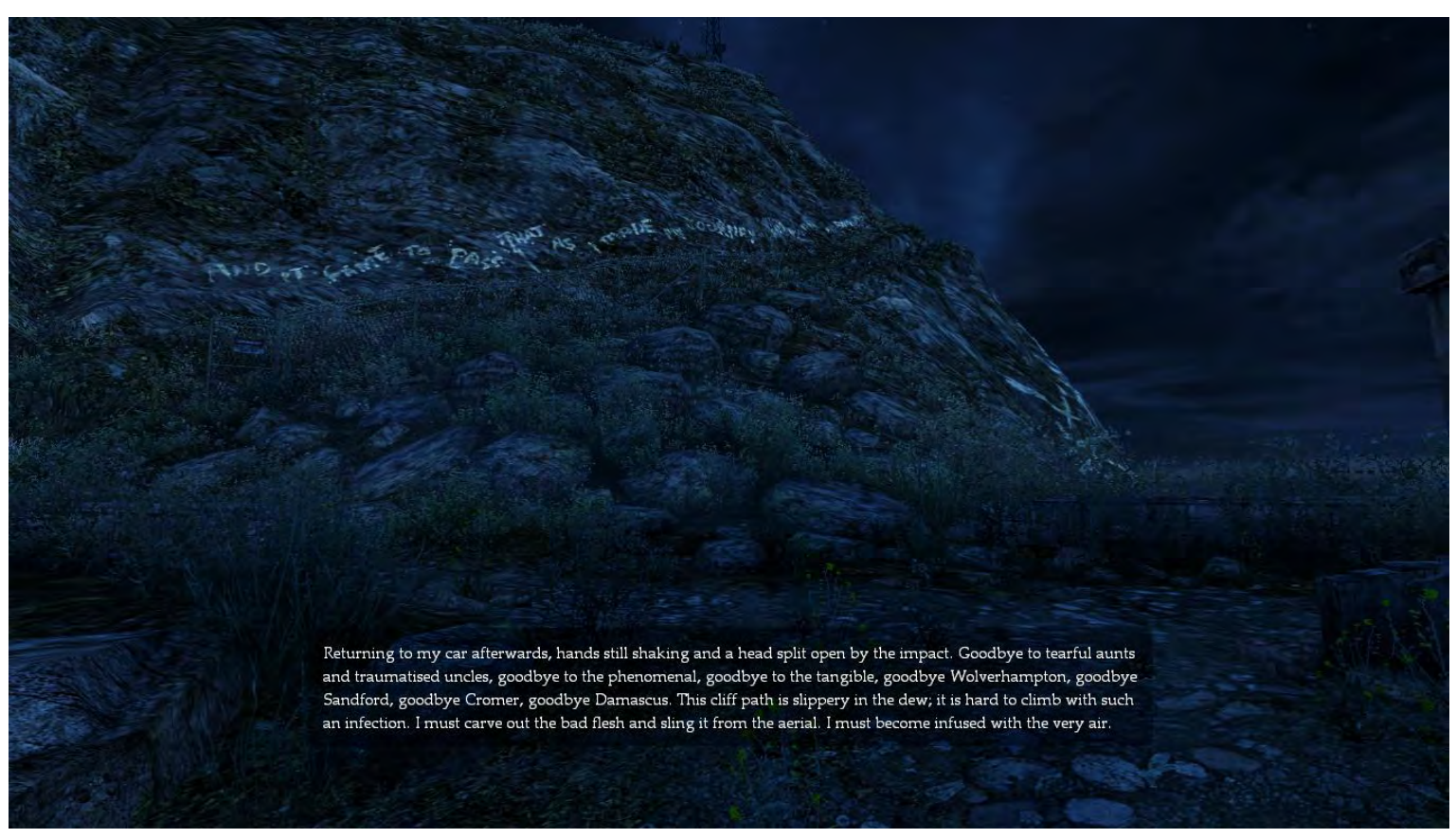

(Figuras 7 a 8: Dear Esther)

Os pedaços de informação narrativa não têm conexão explícita ou lógica, cabendo ao leitor/agente "ligar os pontos" e deduzir por si mesmo o que aconteceu/está acontecendo. Não há um resultado, nem um conflito e os elementos do mundo virtual não se organizam em um sistema de jogo - isso é proposital, como os próprios designers indicam no site: "It abandons all traditional game play, leaving only a rich world soaked in atmosphere, and an abstract, poetic story to explore." ${ }^{44}$ Apesar de ser classificado como um jogo por seus criadores, Dear Esther é, segundo o conceito trabalhado aqui, uma narrativa hipermidiática, isto é, um tipo de produto cultural em que há uma progressão alinear de enredo baseada na experiência de um usuário, mas que não se constitui como jogo por não haver engajamento por parte de um jogador em um conflito - os valores assumidos pelo sujeito da enunciação são de outra ordem.

O exemplo acima, em conjunto com as considerações expostas no Capítulo 2 acerca da aceitação do sistema por parte do jogador, deixa evidente que não há uma correspondência obrigatória entre organização procedural de um ambiente virtual e um jogo $^{45}$. Sendo assim, é preciso investigar como os jogos moldam essa experiência virtual de modo a contar uma história sem que se perca a estrutura-base de conflito regrado. Há diversos exemplos que poderiam ser citados, alguns tendo mais sucesso que outros em

\footnotetext{
${ }^{44} \mathrm{http}: / /$ dear-esther.com/?page_id=2 (acesso em 14/10/2014)

${ }^{45}$ Apesar disso, Murray afirma que o ciberespaço é em larga medida moldado com base na linguagem dos jogos (pp. 128-9).
} 
termos estéticos; limitar-nos-emos, no entanto, ao estudo de uma organização formal que aparenta ser dominante e bastante eficaz em diversos gêneros, a qual denominaremos aqui como forma progressiva ${ }^{46}$.

\subsection{Tendências da proceduralidade progressiva em jogos digitais}

A progressão lúdica em sua forma mais básica compreende uma encenação das relações lógico-formais do nível narrativo do percurso gerativo do sentido, as quais foram formuladas a partir de uma simplificação da morfologia proppiana dos contos maravilhosos. São abundantes os exemplos de enredos organizados a partir de duas situações, uma inicial e outra final, apresentadas em forma de cutscenes (cenas nãojogáveis, muitas vezes compostas por diálogos) que "ensanduícham" o jogo-de-fato, em que o jogador segue em linha reta derrotando inimigos e adquirindo poderes para prosseguir. Os momentos de manipulação, ação e sanção aparecem representados de maneira bastante óbvia: a cutscene inicial figurativiza o estado de conjunção problematizado em que o sujeito é manipulado; o saber e o poder figuram em simultaneidade à realização da performance que consiste em passar pelas fases sem perder todas as "vidas"; e, por fim, a sanção positiva corresponde à cutscene final que não poucas vezes é encerrada com a clássica frase "The End". Em caráter de exemplo, examinemos o jogo The Magical Quest Starring Mickey Mouse (Capcom, 1992).

A tela de início, em que se escolhe a modalidade (para um ou dois jogadores) e pode-se alterar a dificuldade e os controles, mostra as personagens (Mickey, Donald, Pateta e Pluto) em um campo ou parque. A seleção de uma das opções de modalidade dá início à cutscene em que vemos Pluto sumir enquanto persegue a bolinha; ao procurar o cachorro, Mickey acaba caindo de um penhasco e a cena termina com a exibição do mapa de jogo, em que se pode vislumbrar a existência de diversas fases:

\footnotetext{
${ }^{46}$ O termo é emprestado de Juul (2005) que estabelece uma espécie de dicotomia entre duas modalidades de jogo: progressão e emergência. Não se trata, como o próprio autor aponta, de uma polarização absoluta, posto que todo e qualquer jogo apresenta tanto emergência quanto progressão; os dois termos seriam apenas linhasguia para que se possa vislumbrar tendências ora para um ora outro aspecto em cada caso.
} 


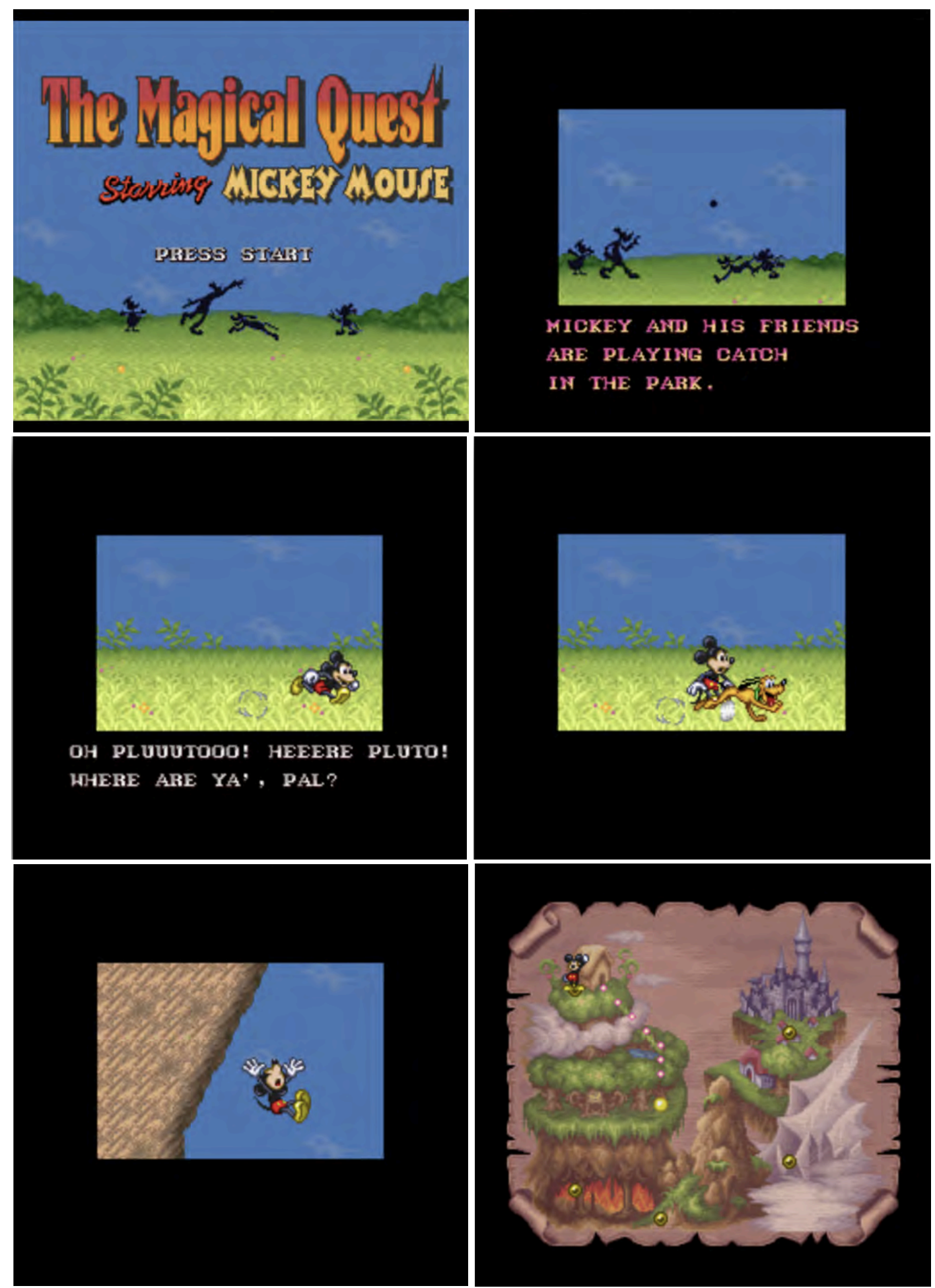

(Figuras 9 a 14: The Magical Quest Starring Mickey Mouse)

Após isso, começa a primeira fase e a busca por Pluto passa a ser encenada pelo jogador, que deve seguir fase a fase as estátuas do Imperador Bafo, o responsável pela captura do cão. A cada estágio, Mickey (e, por consequência, o jogador) enfrenta desafios que crescem em dificuldade e, em alguns momentos, recebe roupas novas que lhe conferem novas habilidades. A relação entre o tema da busca e a progressão linear de jogo, 
na qual o jogador é obrigado a seguir sempre adiante - a navegação pelas fases é sempre com uma orientação horizontal, sendo o lado esquerdo o início e o direito o final, mesmo quando se deve subir ou descer - é, como dissemos, bastante óbvia: o sumiço de Pluto figurativiza uma manipulação do sujeito pelo querer (Mickey quer achar seu cachorro), o saber e o poder são figurativizados pelas roupas mágicas que se recebe ao longo das fases e demonstram o pareamento entre os procedimentos do jogo, que poderíamos associar ao plano da expressão, e os desenvolvimentos narrativo-discursivos do plano do conteúdo. No final da última fase, enfrenta-se o final boss - popularmente conhecido no Brasil como "chefão" - em uma batalha que requer toda a habilidade adquirida pelo jogador ao longo de seu percurso (note-se novamente o pareamento com a personagem Mickey); depois de o final boss derrotado, aparece a cutscene final, em que descobrimos que tudo não havia passado de um sonho ${ }^{47}$.
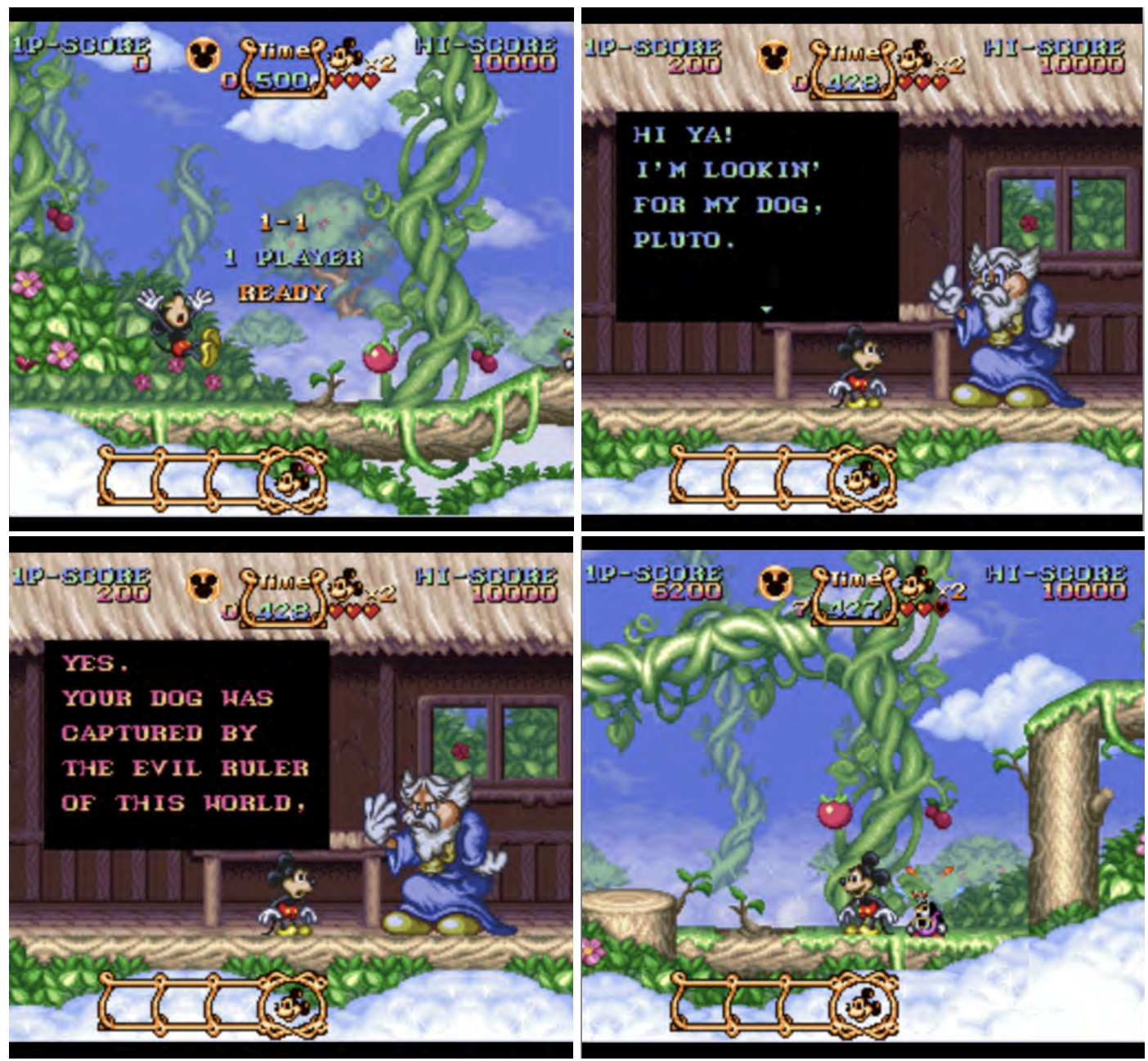

\footnotetext{
${ }^{47}$ A referência à adaptação de Alice no País das Maravilhas feita pela Disney é bastante clara também, demonstrando a afinidade entre esse tipo de jogo e a estrutura de contos de fadas e outras histórias infantis e/ou infanto-juvenis.
} 

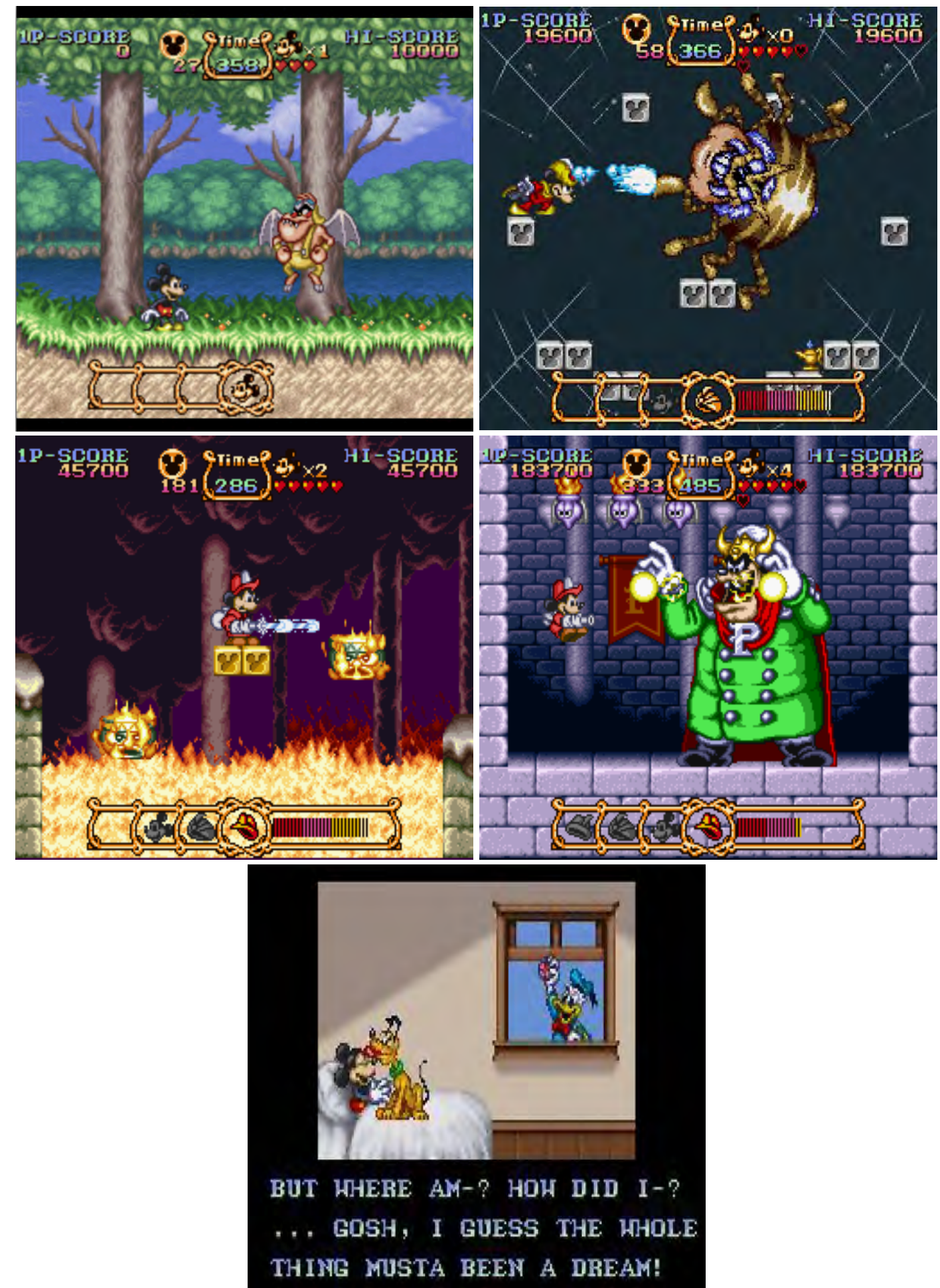

(Figuras 15 a 23: The Magical Quest Starring Mickey Mouse)

A eficiência desse modelo de organização progressiva reside no fato de que se torna desnecessário compreender o que diz o texto para que se absorva a estrutura narrativa: sendo algo relativo ao plano da expressão, o enredo de The Magical Quest Starring Mickey Mouse, como dito acima, estabelece relações de pareamento entre os 
procedimentos do jogo (condições de vitória e de derrota, orientação de cenário) e os desenvolvimentos do plano de conteúdo, garantindo, assim, que o jogador vivencie a temática da busca; trata-se de algo da ordem do sentir, como exposto no Capítulo 2: selecionar a modalidade de jogo e dar início efetivo à encenação faz com que nos tornemos, ao mesmo tempo, jogadores e personagens, sujeitos da enunciação-jogo e do enunciado-história que se constitui no e pelo ato de jogar.

O caso de The Magical Quest Starring Mickey Mouse é bastante arquetípico e corresponde a diversos outros jogos famosos, dentre os quais poderíamos citar Donkey Kong Country (Rare, 1994), Captain Commando (Capcom, 1991), Teenage Mutant Ninja Turtles IV: Turtles in Time (Konami, 1991). Outros exemplos que ilustram bem a ideia de progressão linear são jogos de luta como Street Fighter (Capcom, 1987) e Mortal Kombat (Midway, 1992) nos quais se encena um torneio; o jogador escolhe um dos lutadores disponíveis e, após a última luta, há geralmente uma cutscene apresentando informações sobre a personagem escolhida.

Um caso interessante e bastante recente é o de Injustice: Gods Among Us (NetherRelm, 2013) em que a modalidade de jogo denominada "História" coloca o jogador diante de um complexo de cutscenes que se assemelham a um filme de animação; nos momentos-chave, assume-se o controle da personagem em foco e um combate começa nos moldes dos jogos de luta tradicionais, com a vitória garantindo a continuidade da animação. Em vez de uma progressão linear em torno de uma única personagem, Injustice: Gods Among Us divide o papel temático de sujeito da narrativa em diversas figuras diferentes; o jogador, no entanto, mantém sua identidade como tal, na medida em que ele ainda precisa querer obedecer às regras para que haja jogo. As quatro imagens abaixo ilustram uma transição entre animação e combate jogável do capítulo 12 do jogo, dedicado à Mulher Maravilha: 


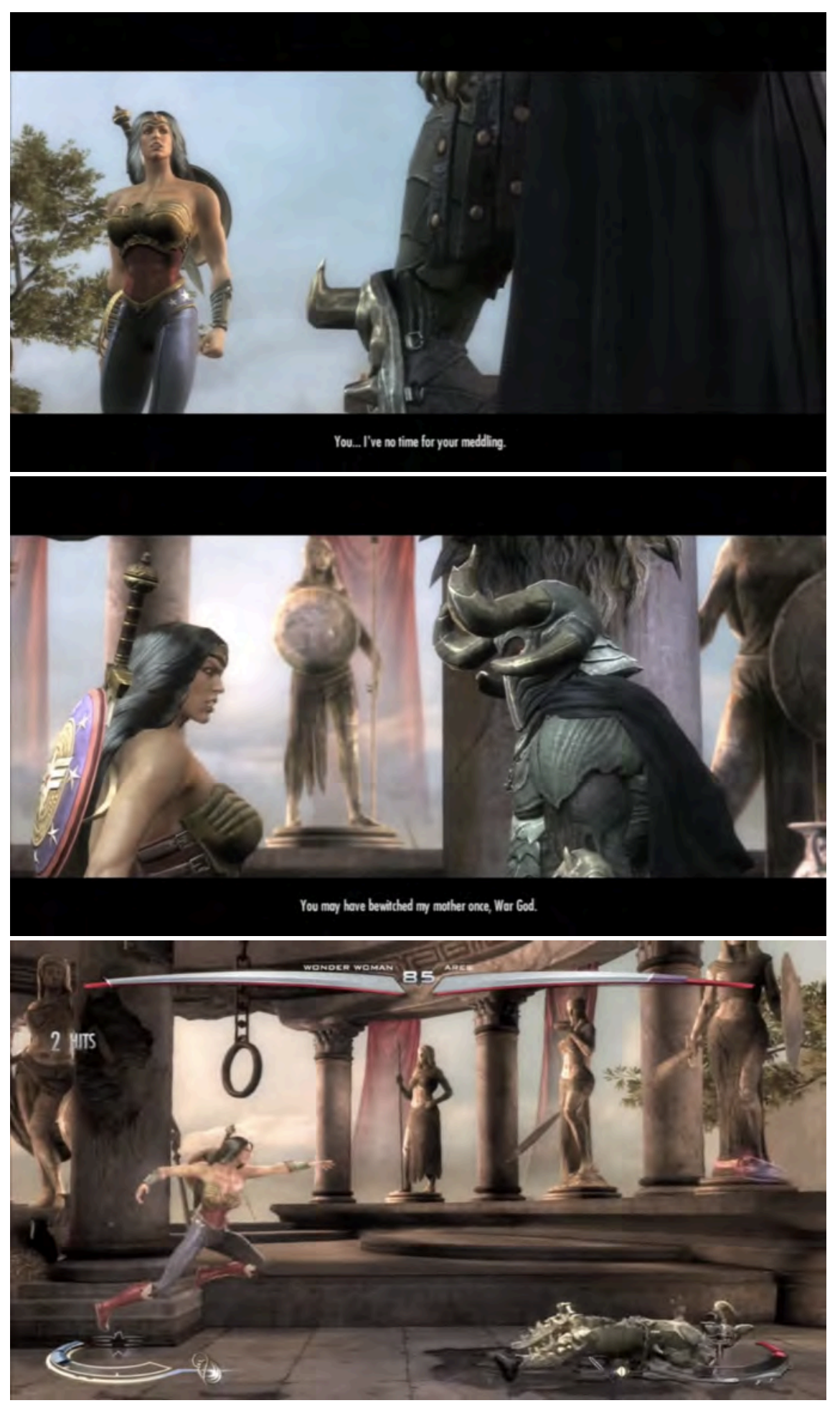




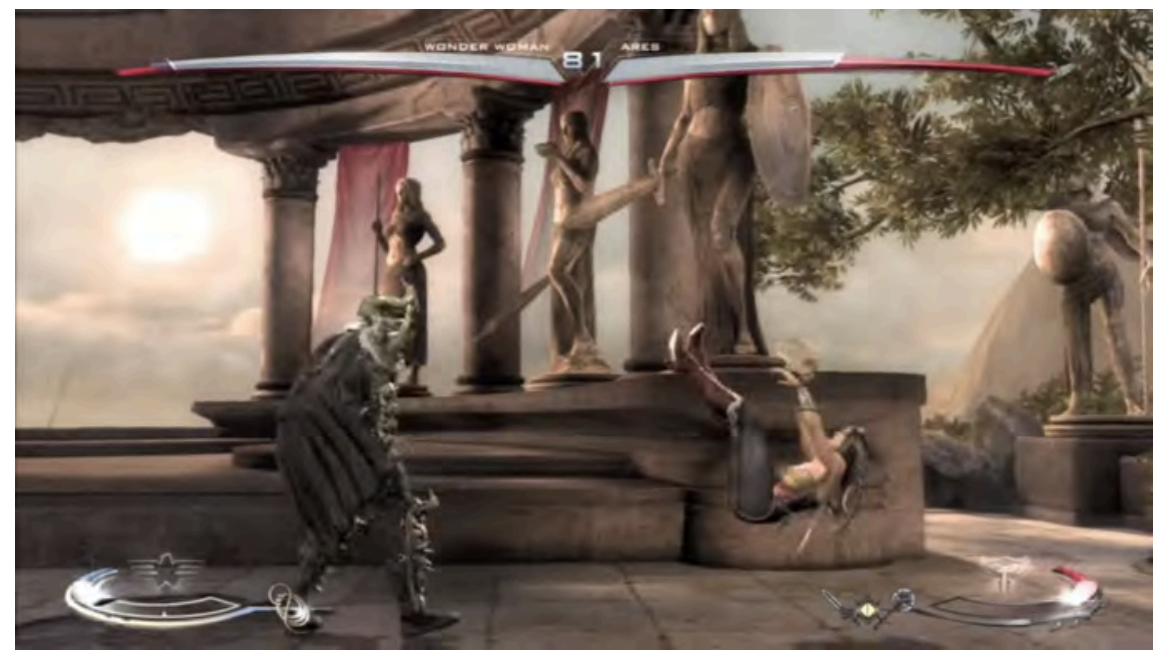

(Figuras 24 a 27: Injustice: Gods Among Us)

Há, no entanto, outras maneiras de estruturar um enredo progressivamente em um jogo digital; dentre elas destaca-se uma, que denominaremos jogo de acesso progressivo. Esse modelo corresponde a jogos que não se baseiam necessariamente em uma sucessão de estágios lineares, mas na criação de um ambiente subdivivido em diversas áreas, demarcadas por nome ou não, às quais o jogador não tem acesso total no início do jogo. É preciso que se explore cuidadosamente os espaços disponíveis em busca de itens ou dicas que possibilitem a progressão, em uma organização que é, muitas vezes, labiríntica.

Diversos títulos poderiam ser enquadrados nessa categoria, sendo Super Metroid (Nintendo, 1994) um dos mais aclamados. O jogo consiste, basicamente, na busca de uma larva da espécie alienígena chamada Metroid que foi roubada de uma estação espacial por piratas e levada ao planeta Zebes. O jogador, que controla a caçadora de recompensas Samus Aran, tem pouquíssimas possibilidades de exploração no início do jogo; a cada novo item encontrado, torna-se possível abrir novas portas e alcançar determinadas áreas. $\mathrm{Na}$ imagem abaixo (Figura 28) é possível ver duas portas, uma à esquerda e outra à direita, que requerem cada uma um tipo de tiro diferente para abrir (normal e míssil, respectivamente); nesse estágio do jogo, ainda é impossível atravessar a porta rosa, então a única alternativa do jogador é quebrar o chão e prosseguir para baixo. 


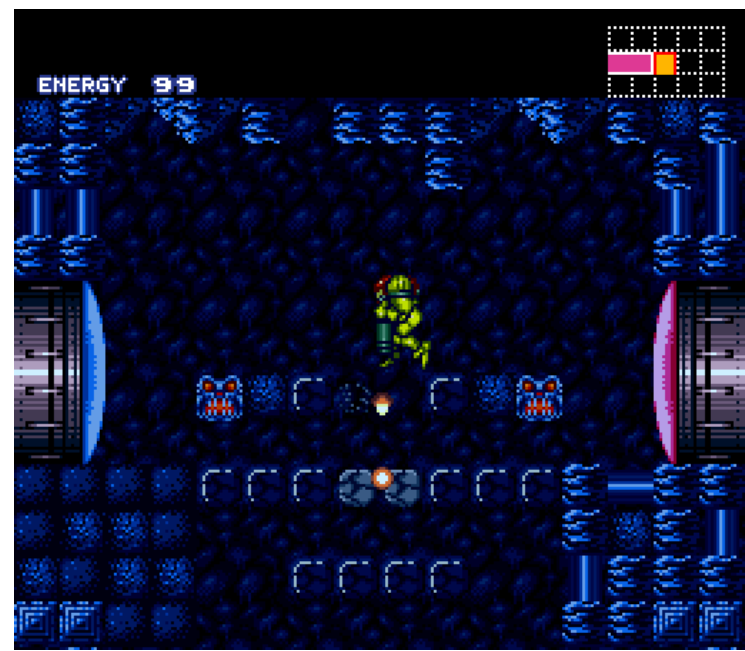

(Figura 28: Super Metroid, o jogador precisa quebrar o chão para ganhar acesso a uma nova área)

A aquisição de itens é, como dito, resultado da exploração de cada uma das salas disponíveis no jogo até o momento. Na imagem abaixo (Figura 29), Samus encontra seu Speed Booster, que lhe permite correr rapidamente e atravessar áreas em que o chão é destruído caso o jogador tente andar normalmente sobre ele.

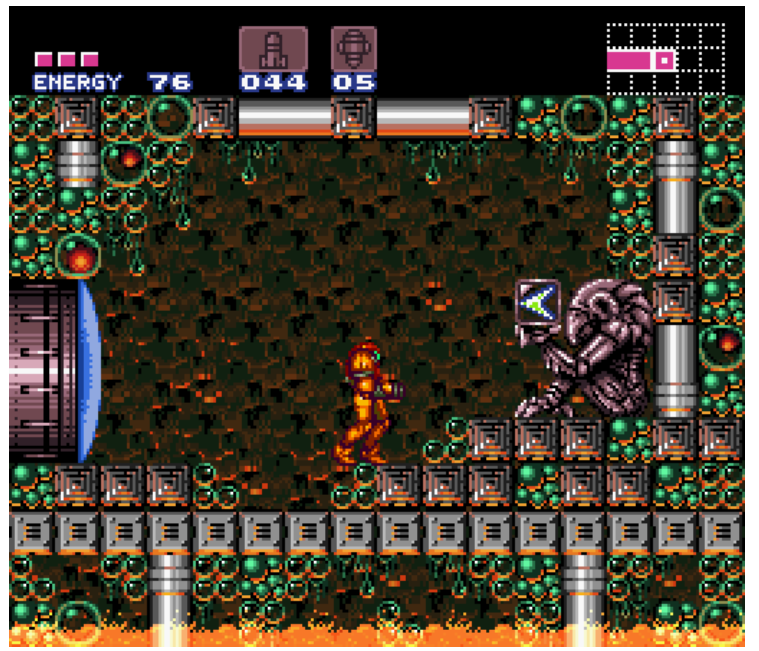

(Figura 29: Super Metroid, o jogador encontra o Speed Booster)

Outro exemplo pode ser visto na imagem abaixo (Figura 30), em que o único meio de atravessar o abismo é usar o gancho (destacado em verde na parte superior) que deve ser adquirido em algum ponto do jogo: 


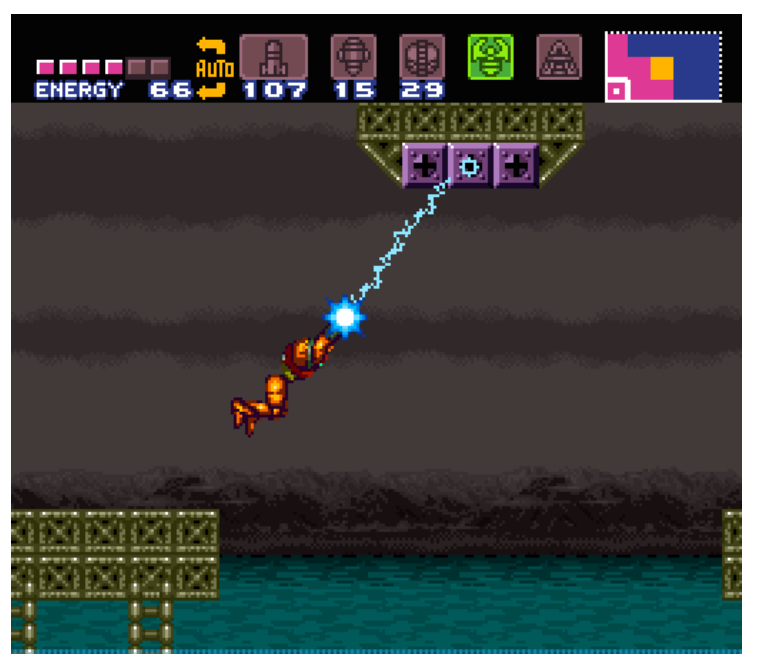

(Figura 30: Super Metroid, o jogador usa o gancho para cruzar o abismo)

Evidentemente, apenas com a armadura de Samus completa é possível transitar livremente pelo planeta Zebes. A comparação das duas imagens abaixo mostra a diferença entre um estágio mais próximo do início e outro em que há possibilidade de acesso irrestrito:

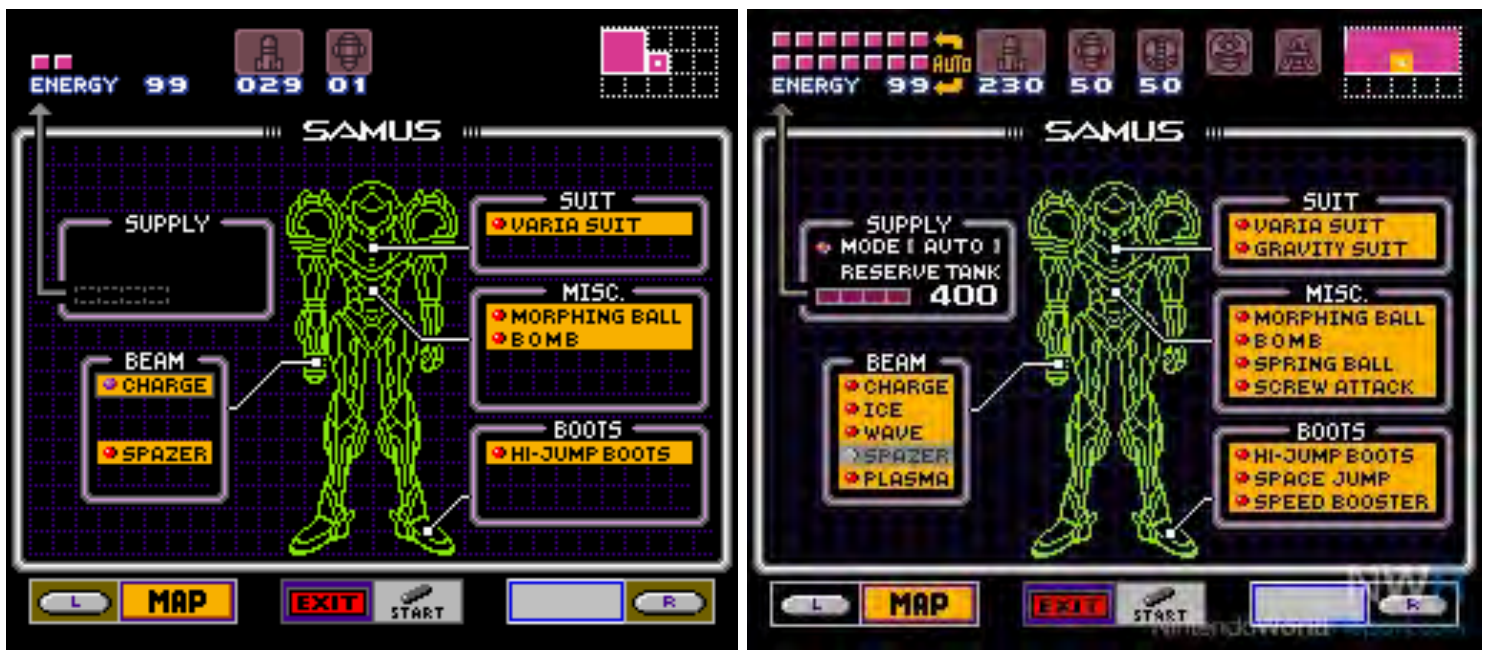

(Figuras 31 e 32: Super Metroid, estágios diferentes da armadura de Samus)

A orientação do jogador perde, de modo evidente, seu caráter linear, pois não há, diferentemente de em The Magical Quest Starring Mickey Mouse, um começo e final de fase em que se parte obrigatoriamente do lado esquerdo para terminar no lado direito. Horizontalidade e verticalidade se misturam e não se sabe em momento algum onde a jornada irá terminar; o caráter investigativo é bastante salientado nesse tipo de procedimento, adequando-se aos desenvolvimentos do plano do conteúdo: uma caçada por algo escondido em um planeta. Nas imagens abaixo (Figuras 33 a 35) é possível ver o mapa do jogo (ao qual o jogador tem acesso pelo menu), que precisa ser completado pouco 
a pouco tanto por exploração quanto por meio de itens especiais que atualizam os dados disponíveis ao jogador:

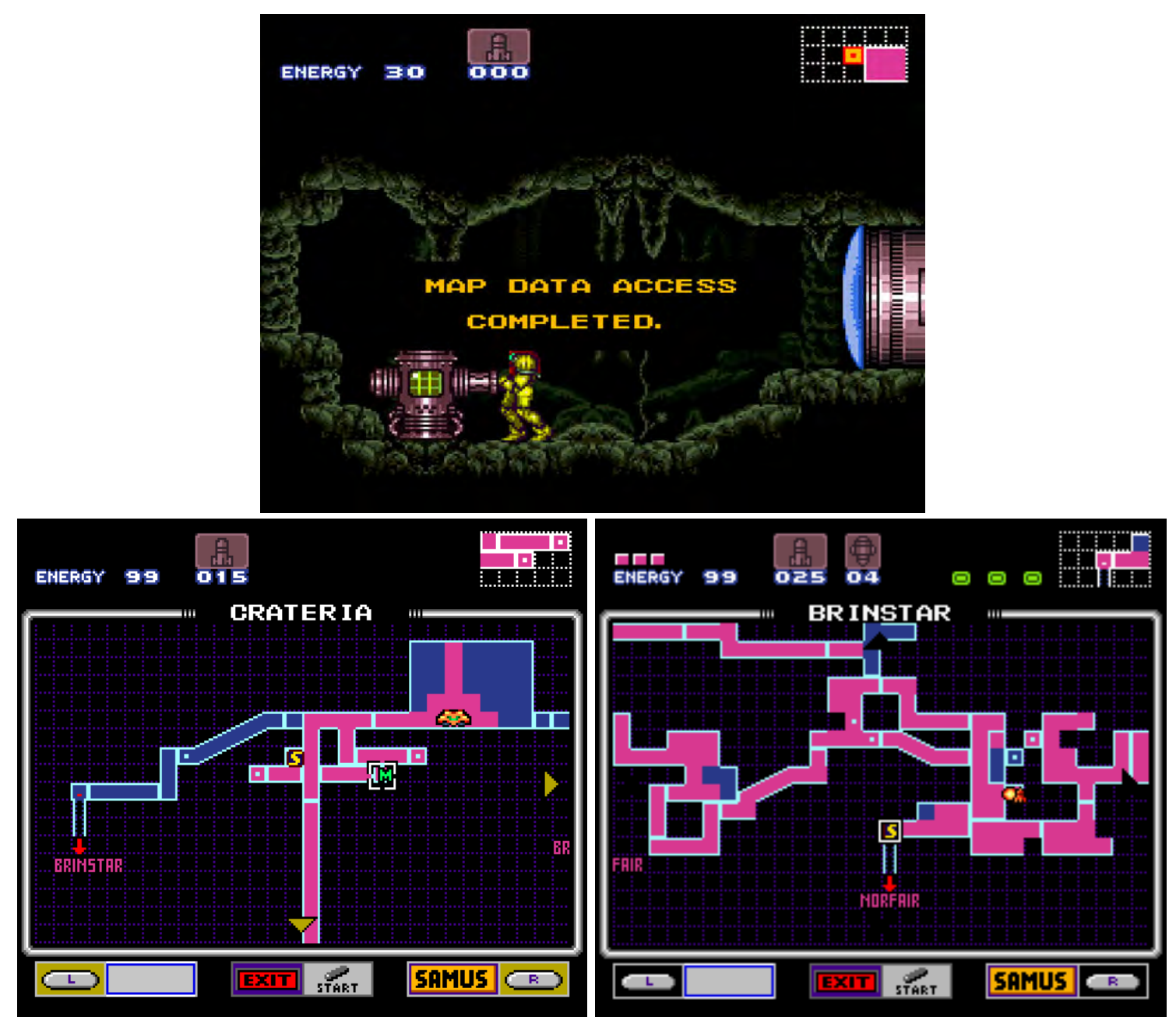

(Figuras 33 a 35: Super Metroid, o mapa do jogo)

Trata-se, evidentemente, de um tipo diferente de encenação e, portanto, de experiência semiótica. É interessante observar que não se trata de uma forma melhor ou pior que a outra, mas de uso de maneiras diversas de organização de enredo que servem, cada uma, a um fim específico. Diversos jogos classificados na categoria "adventure", como Super Mario World (Nintendo, 1992) e Banjo-Kazooie (Rare, 1998), misturam acesso progressivo com progressão linear de fase ao estabelecer uma distinção entre o "mundo principal" e as diversas fases ou "mundos individuais" - no caso, há fases inseridas dentro de um contexto maior e, para avançar, é preciso passar por cada estágio individualmente. A diferença básica entre esses dois exemplos e um jogo de acesso 
progressivo "puro" é que as subáreas formam uma unidade distinta, fechada em si mesma, e o direcionamento geral do jogo é bastante linear.

As relações entre os procedimentos e os elementos do plano do conteúdo diferem não somente em relação a essa dinâmica de linearidade versus acesso progressivo alinear, mas dentro de um mesmo tipo por fatores como ritmo e aspecto dos valores, criando os chamados gêneros - caso contrário, todo jogo de acesso progressivo seria igual. Usaremos os jogos Resident Evil (Capcom, 1996; 2002 ${ }^{48}$ ) e Silent HIll (Konami, 1999), ambos considerados jogos de Survival Horror, para demonstrar esse ponto.

\section{O gênero Survival Horror}

Survival Horror ${ }^{49}$ é o termo que designa um gênero (ou talvez subgênero ${ }^{50}$ ) de jogos de acesso progressivo. Determinado não só por sua estrutura procedural, mas também por suas por características temático-figurativas, a ideia básica de um jogo como esse é "sair vivo" de uma situação de terror. Essa definição, no entanto, diz muito pouco; tendo em vista que não só inexiste uma ideia única e precisa do que venha a causar terror, medo ou angústia, mas também não há um ritmo ou aspecto padrão que seja associado a qualquer uma dessas paixões. É preciso, portanto, analisar casos diversos e contrastá-los para determinar que tipo de relação está sendo proposta. Como dito acima, foram escolhidos dois títulos; o critério de seleção foi o de popularidade e influência.

Em Resident Evil o jogador deve escolher entre as personagens Chris Redfield e Jill Valentine, que fazem parte da Equipe Alfa de policiais enviada para averiguar a causa do desaparecimento da Equipe Bravo, encarregada de investigar casos bizarros de assassinato com sinais de canibalismo em uma região próxima a Raccoon City. Uma cutscene mostra que, ao chegar no local, os policiais encontram uma mão decepada e são atacados por cães ferozes, sendo obrigados a abrigar-se em uma mansão supostamente abandonada nas proximidades. A partir daí o jogador deve controlar a personagem escolhida e investigar a mansão para encontrar pistas que expliquem o incidente e encontrar os membros

\footnotetext{
${ }^{48}$ A segunda data refere-se ao remake para Nintendo GameCube do título original, lançado para Playstation. Utilizamos as duas referências, pois as imagens aqui disponíveis foram retiradas de ambas. A identificação de qual versão veio a figura é bastante fácil: o remake apresenta melhor qualidade de imagem (mais detalhes e definição maior).

${ }^{49}$ Algo como "Terror de Sobrevivência" em português.

${ }^{50}$ Não discutiremos definições de gênero, aqui, por fugir ao escopo do trabalho, mas tão somente assinalamos não haver na área um conceito de gênero único e indiscutível.
} 
desaparecidos das equipes Alfa e Bravo. A escolha inicial de personagem define quem desaparece e em qual momento. Caso o jogador escolha controlar Chris, a cutscene termina com Chris, Jill e Albert Wesker no hall de entrada; o jogador deve explorar a sala de jantar adjacente sozinho para procurar pistas do desaparecimento de Barry Burton e, quando volta ao hall, encontra a pistola de Jill no chão e nenhum sinal dos companheiros. Escolhendo Jill, quem desaparece é Chris; a investigação da sala de jantar é feita em conjunto com Barry e, ao retornar ao hall, descobrem que Wesker também desapareceu; nesse momento, Jill e Barry se dividem para explorar áreas diferentes da mansão ${ }^{51}$. A distinção parece insignificante, mas o desaparecimento de Barry quando se joga com Chris muda a dinâmica de jogo na medida em que, quando se escolhe Jill, a personagem reaparece em alguns momentos-chave para ajudar seja com itens ou para salvar o jogador de alguma enrascada. Escolher Chris introduz também a personagem Rebecca Chambers, sobrevivente da Equipe Bravo, que o jogador controla em algumas passagens do jogo.

Um exemplo da diferença pode ser visto logo após o primeiro encontro com a cobra gigante. Para abrir a porta que leva ao jardim, é preciso reunir quatro pequenas placas e inseri-las num painel que destrava a porta; esses itens podem ser encontrados em pontos diferentes da mansão e, para acessar um deles, o jogador deve, obrigatoriamente, passar por uma cobra gigante:

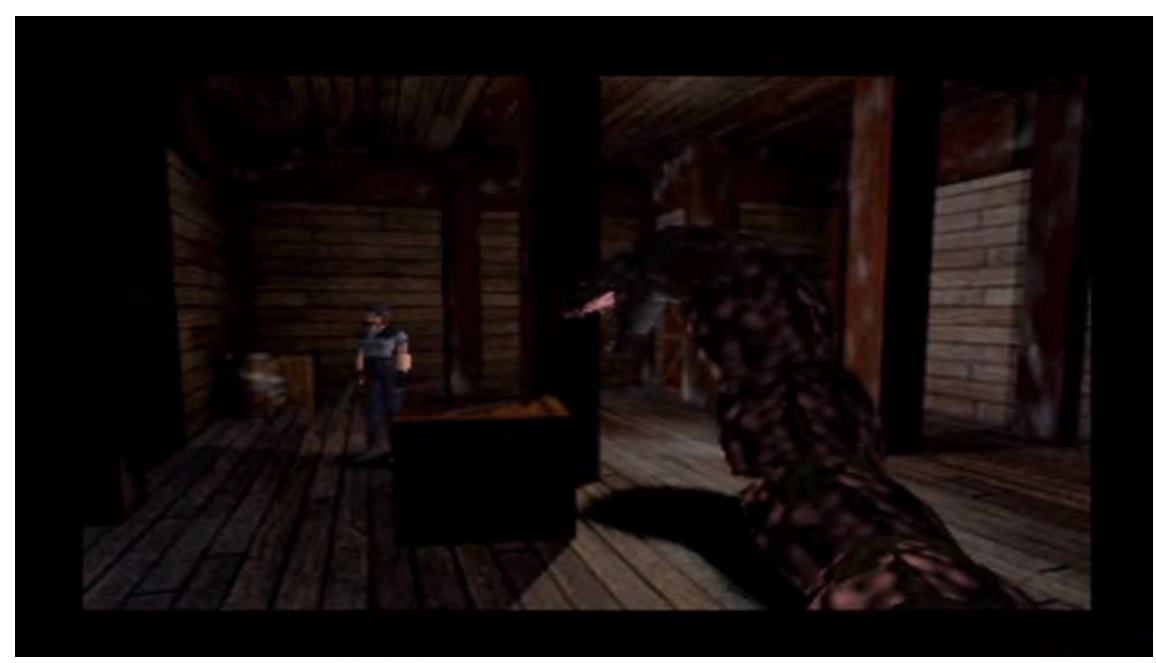

\footnotetext{
${ }^{51}$ Essas informações são baseadas na versão de 1996.
} 


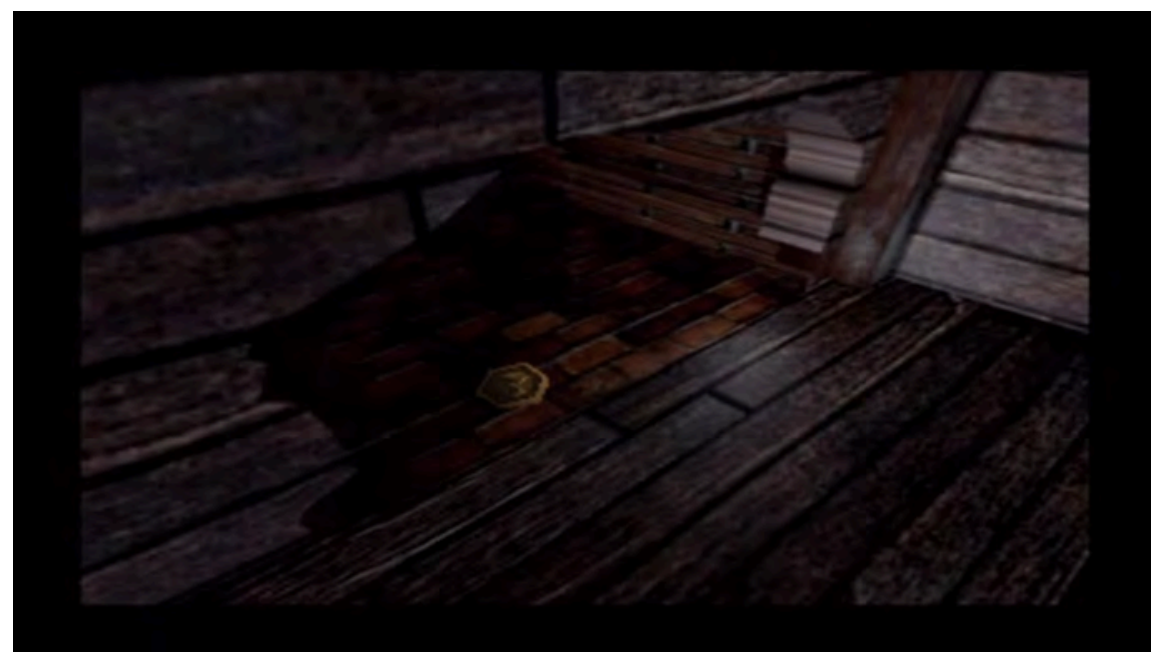

(Figuras 36 e 37: Resident Evil, a sala da cobra)

Independentemente do que ocorre dentro da sala (é possível ser mordido e até mesmo devorado pela cobra, resultando em Game Over), sair com de lá com a placa dá início a uma cutscene em que se descobre que a personagem foi envenenada. Caso se esteja jogando com Jill, Barry aparecerá e o jogador será transportado para uma pequena enfermaria:

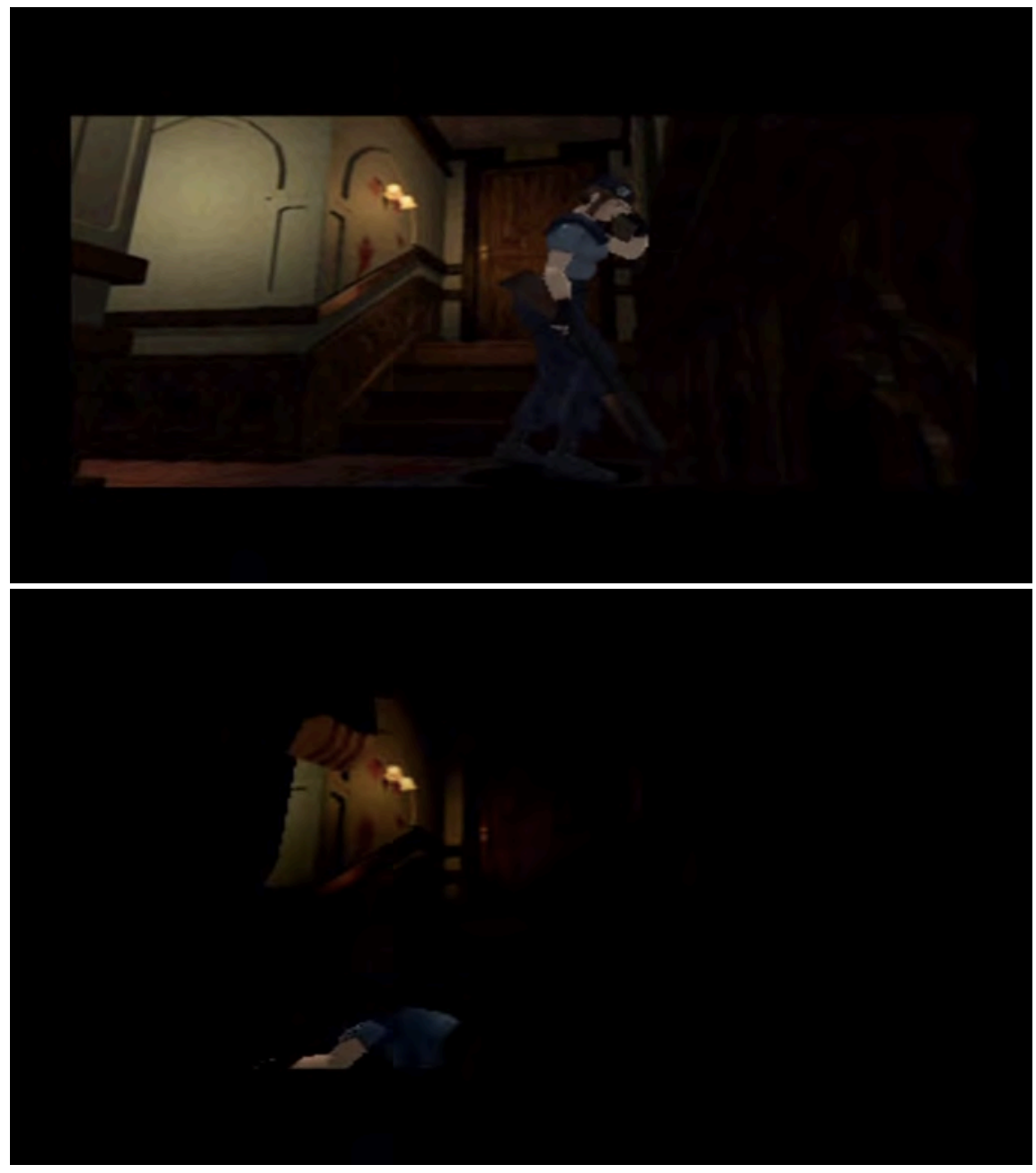




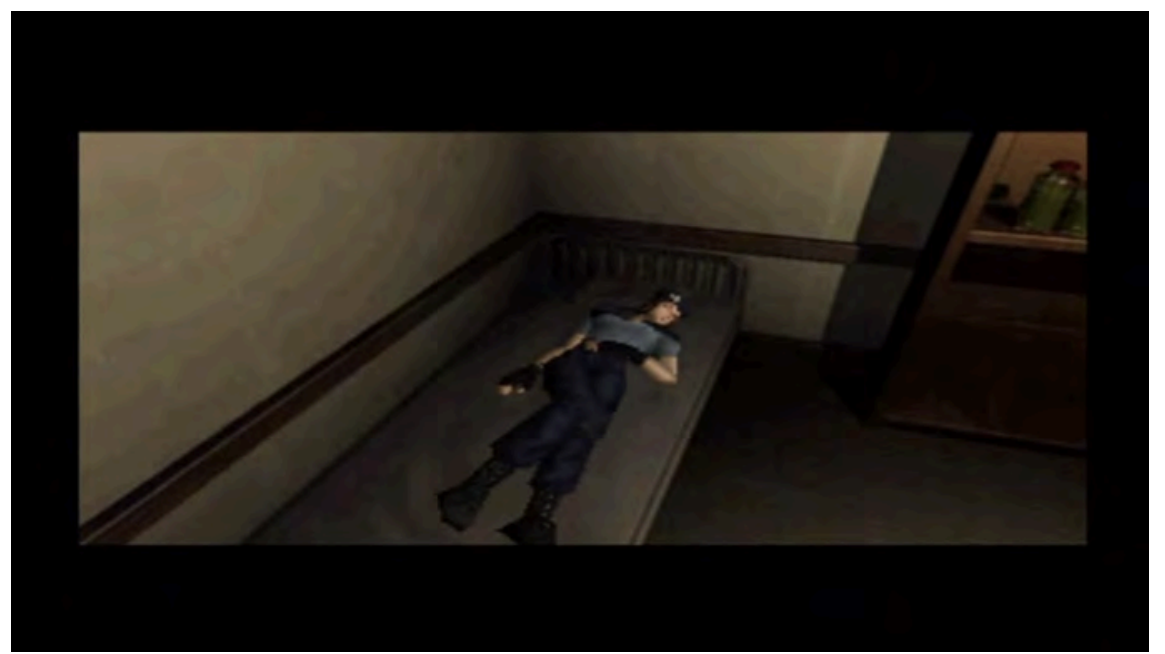

(Figuras 38 a 40: Resident Evil, os eventos após a cobra quando se joga com Jill)

Caso o jogador tenha escolhido Chris no início, Rebecca irá aparecer, mas não haverá transporte; em vez disso, passa-se a controlar a moça e é preciso descer à enfermaria e buscar o soro:

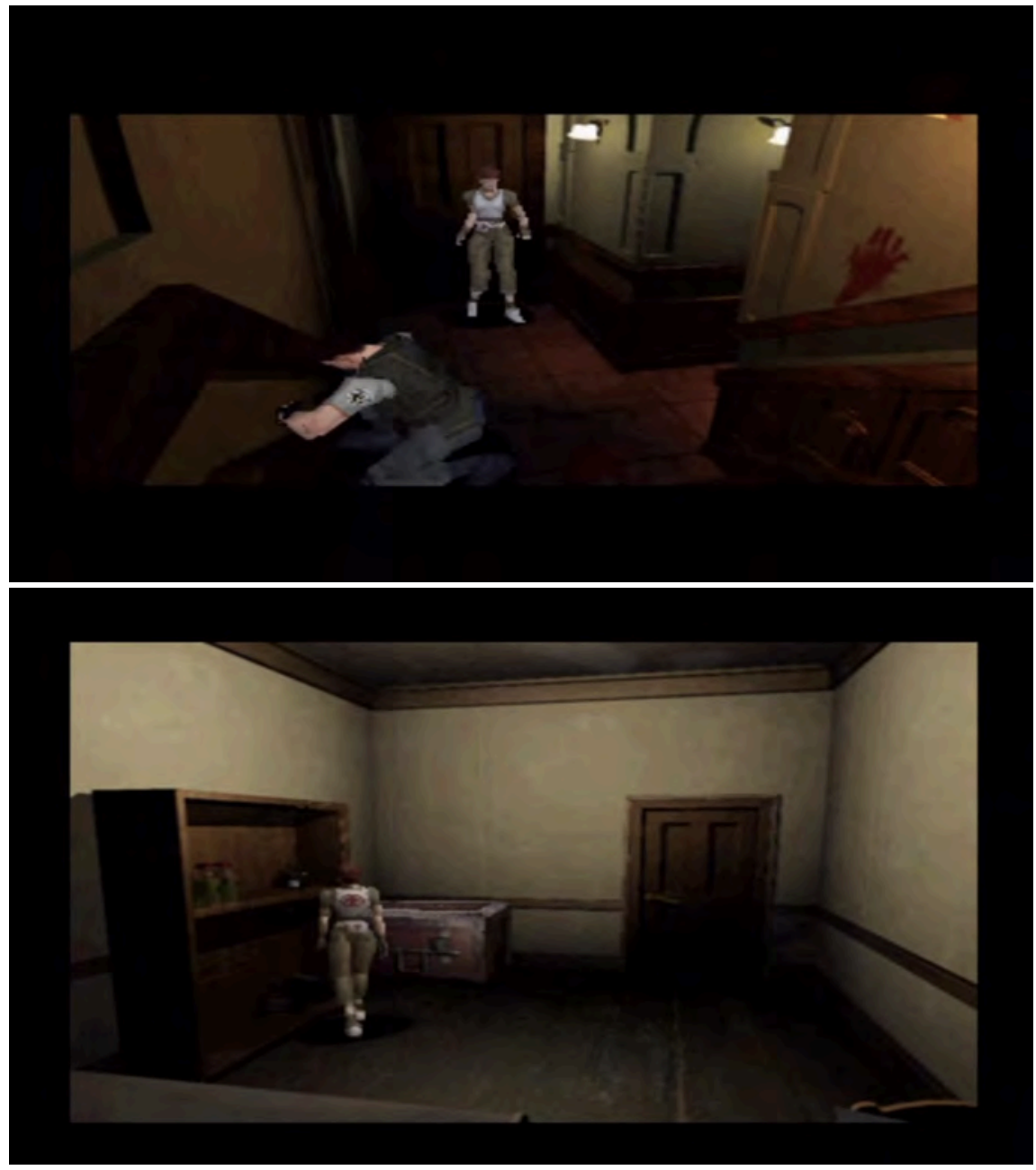




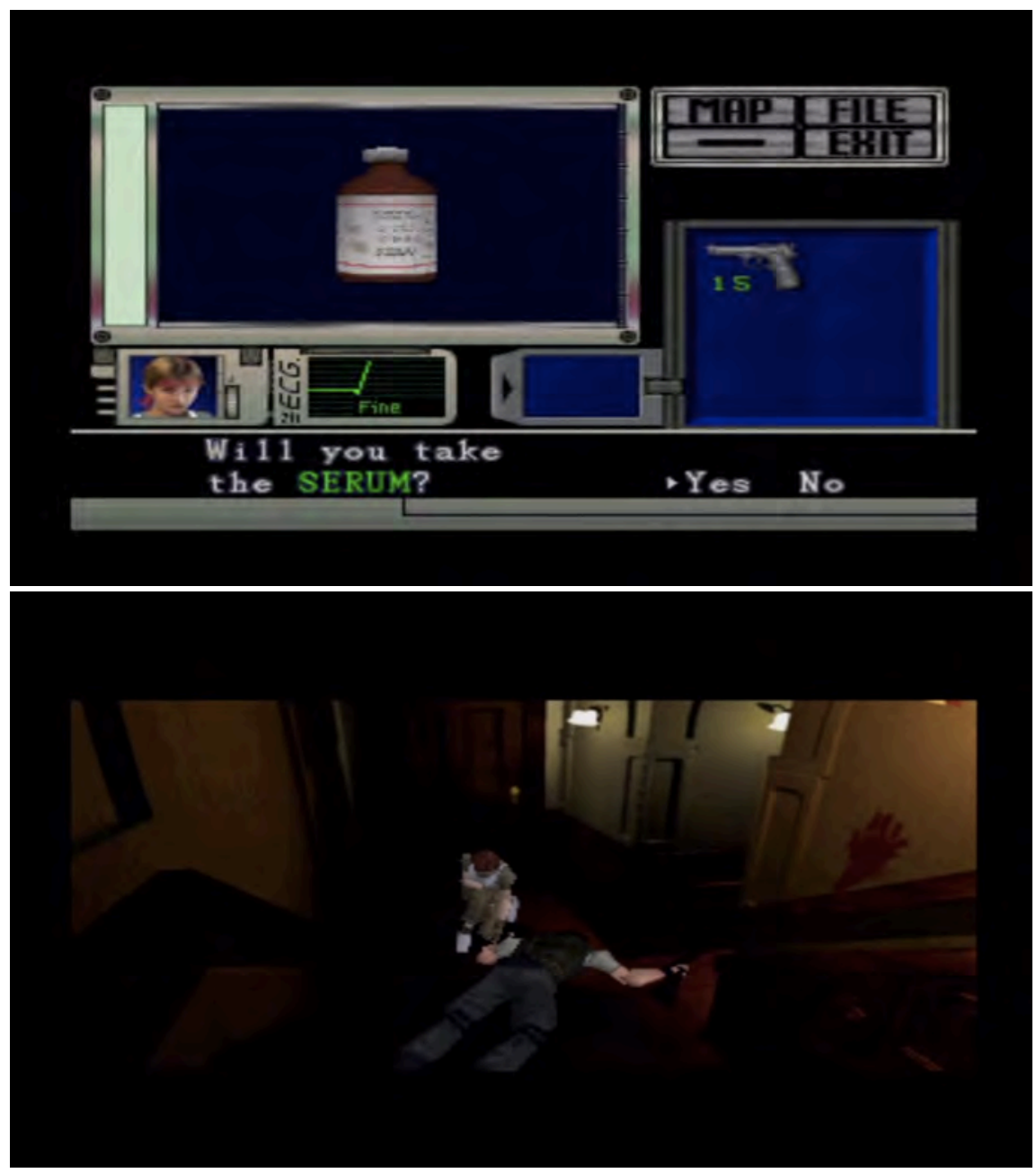

(Figuras 41 a 44: Resident Evil, os eventos após a cobra quando se joga com Chris)

Outro exemplo de mudança está relacionado aos itens: a quantidade que pode ser carregada de uma só vez pelo jogador é bastante restrita. Isso vale para ambas as personagens, mas escolher Jill faz com que se possa carregar dois itens a mais do que quando se joga com Chris:

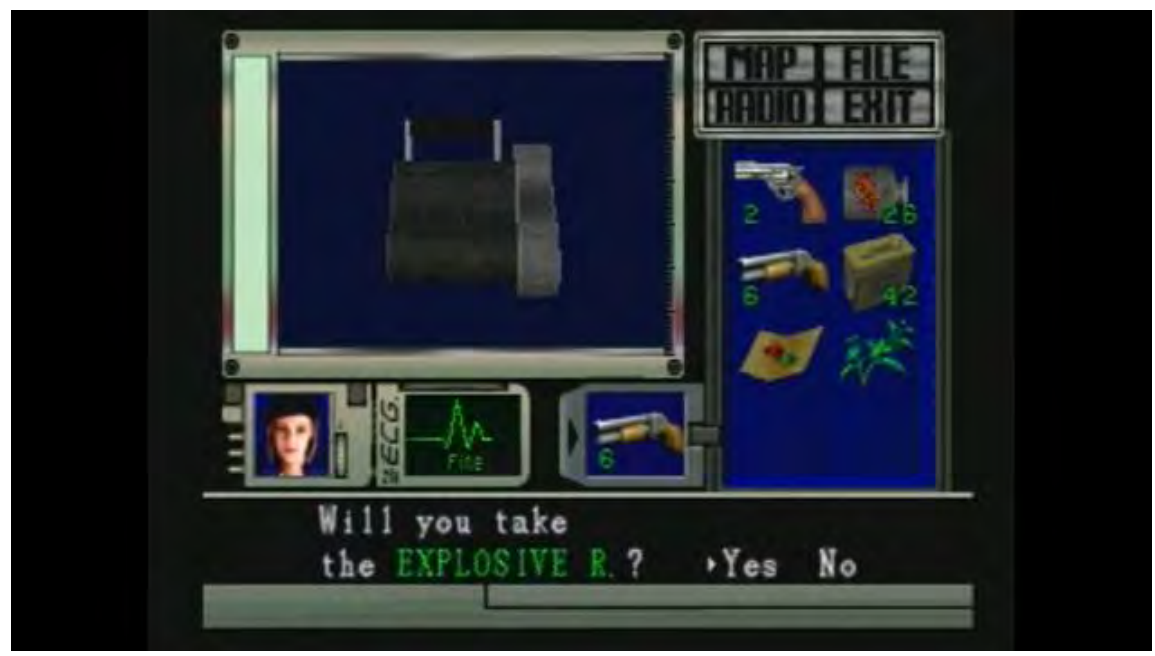




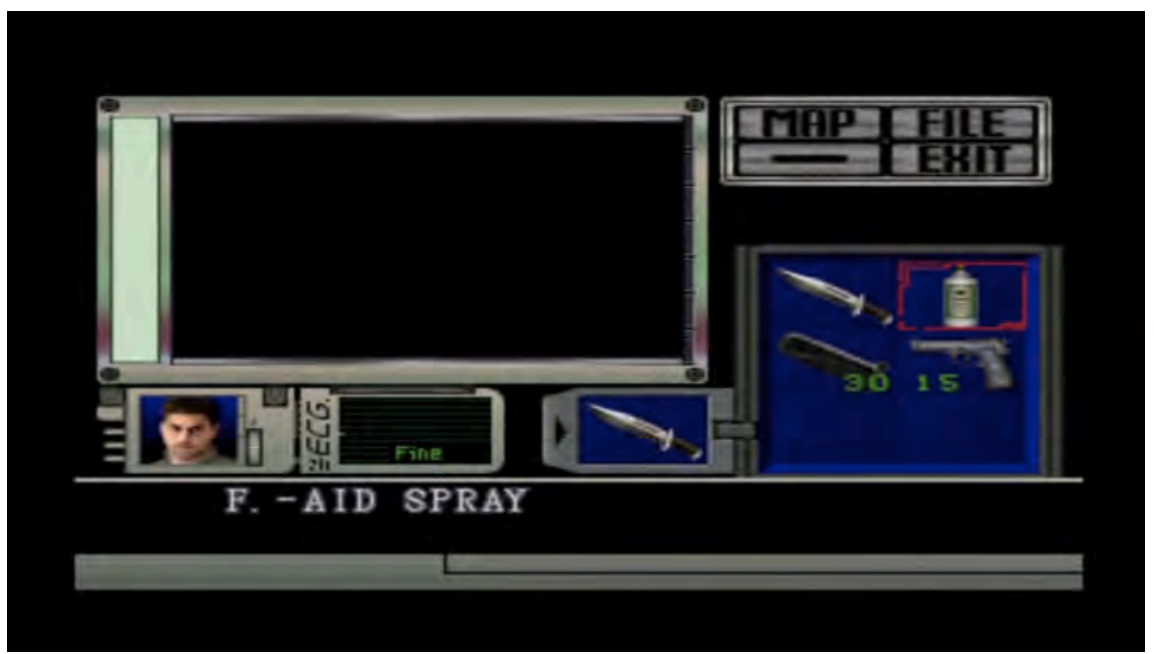

(Figuras 45 e 46: Resident Evil, os menus de Jill e Chris)

Essa característica procedural obriga o jogador a fazer uso dos baús localizados em pontos estratégicos (o mapa que se encontra entre as imagens abaixo mostra as localizações) para guardar itens que não são necessários no momento; apesar de ser possível acessar todo o inventário armazenado a partir de qualquer um deles, o acesso progressivo impede muitas vezes que se possa chegar à sala que contém o baú mais próximo, obrigando o jogador a retroceder os passos ou tomar rotas alternativas dentro da mansão. Como a escassez de recursos (munição e itens curativos) impede que se eliminem todos os inimigos, a necessidade de passar várias vezes pelos mesmos lugares aumenta os riscos e cria um clima de tensão crescente - sobretudo se o jogador encontra-se despreparado para lidar com eventuais crises. A ambientação dos cenários (corredores estreitos, posicionamento da câmera) contribuem para isso:

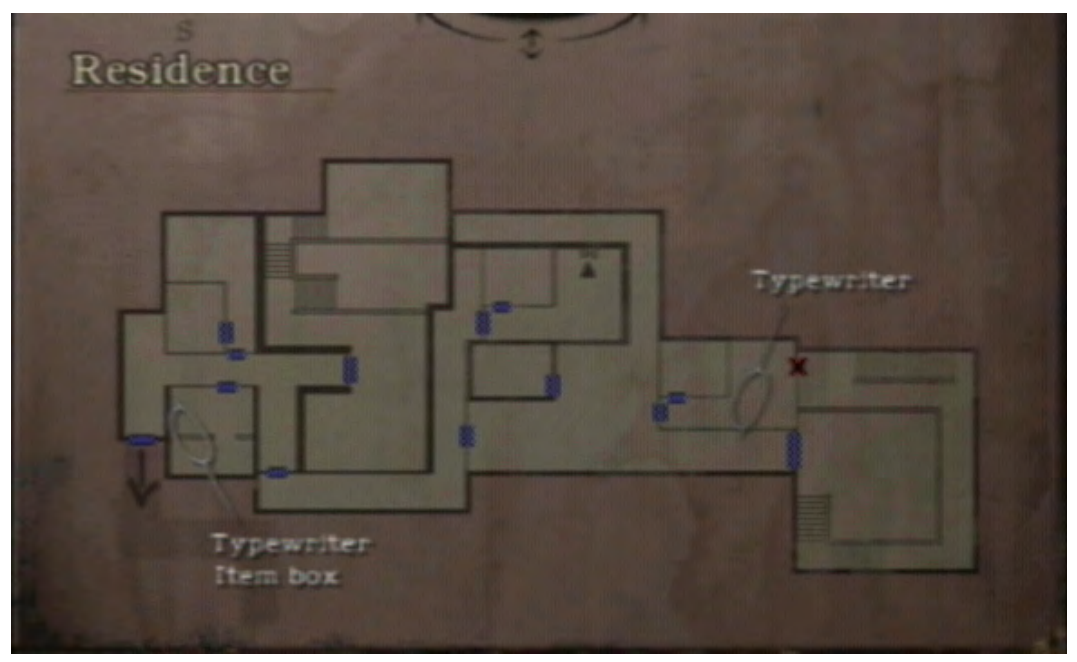

(Figura 47: Resident Evil, mapa de uma das áreas) 


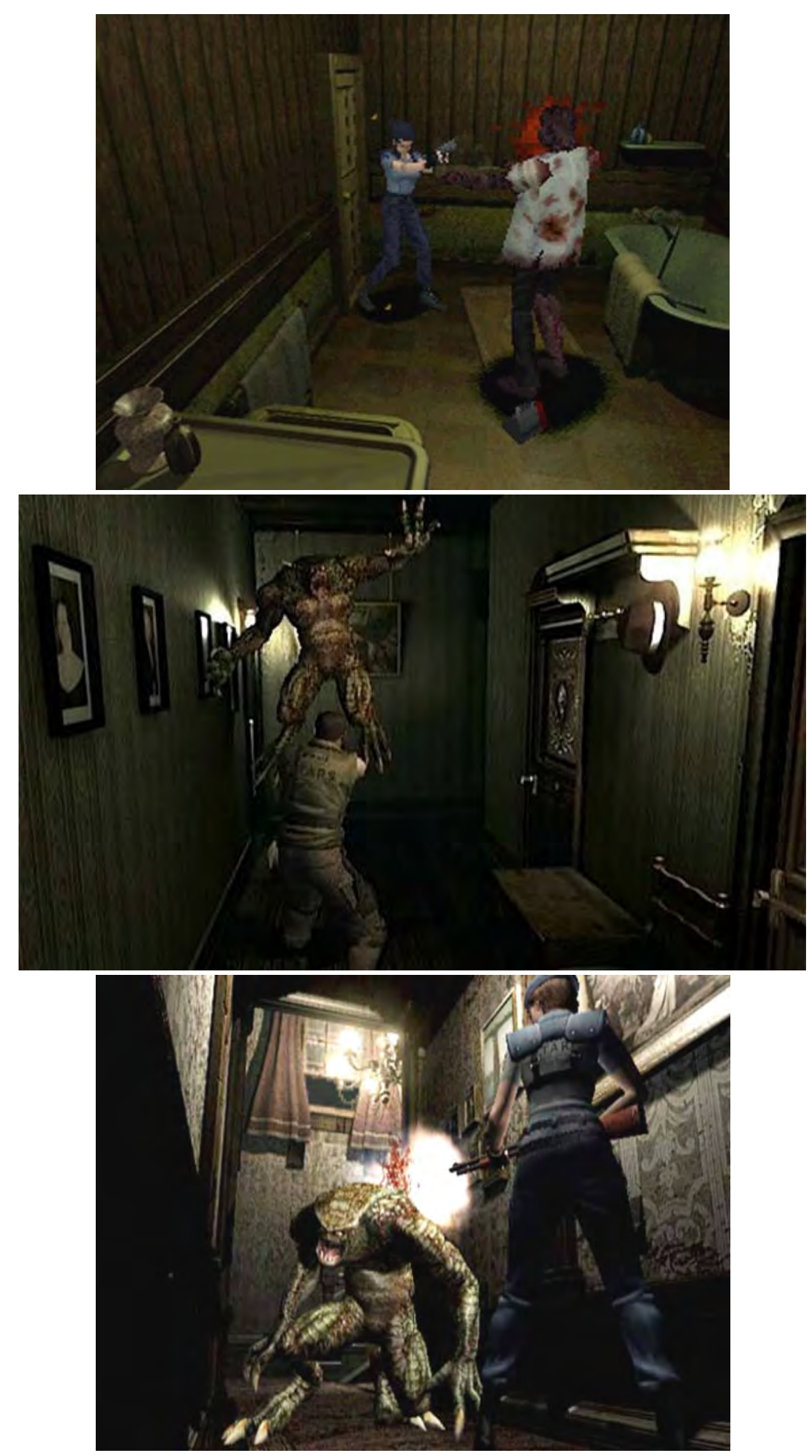

(Figuras 48 a 50: Resident Evil, cenários variados)

Assim como em Super Metroid, o desenvolvimento dos planos do conteúdo é relacionado a técnicas de enredo no plano da expressão. Um ponto bastante interessante de Resident Evil é a existência de documentos e arquivos escondidos ao longo das diversas salas e que contêm texto - trechos de diários, documentos confidenciais, contratos e outros 
do mesmo tipo (Figuras 51 e 52). O jogador tem acesso às informações acerca da história por trás dos acontecimentos bizarros que envolvem a mansão - bem como a senhas para acesso a portas trancadas e a dicas para a solução de enigmas - aos poucos; além disso, deve-se "somar dois e dois" por conta própria, como em uma investigação:

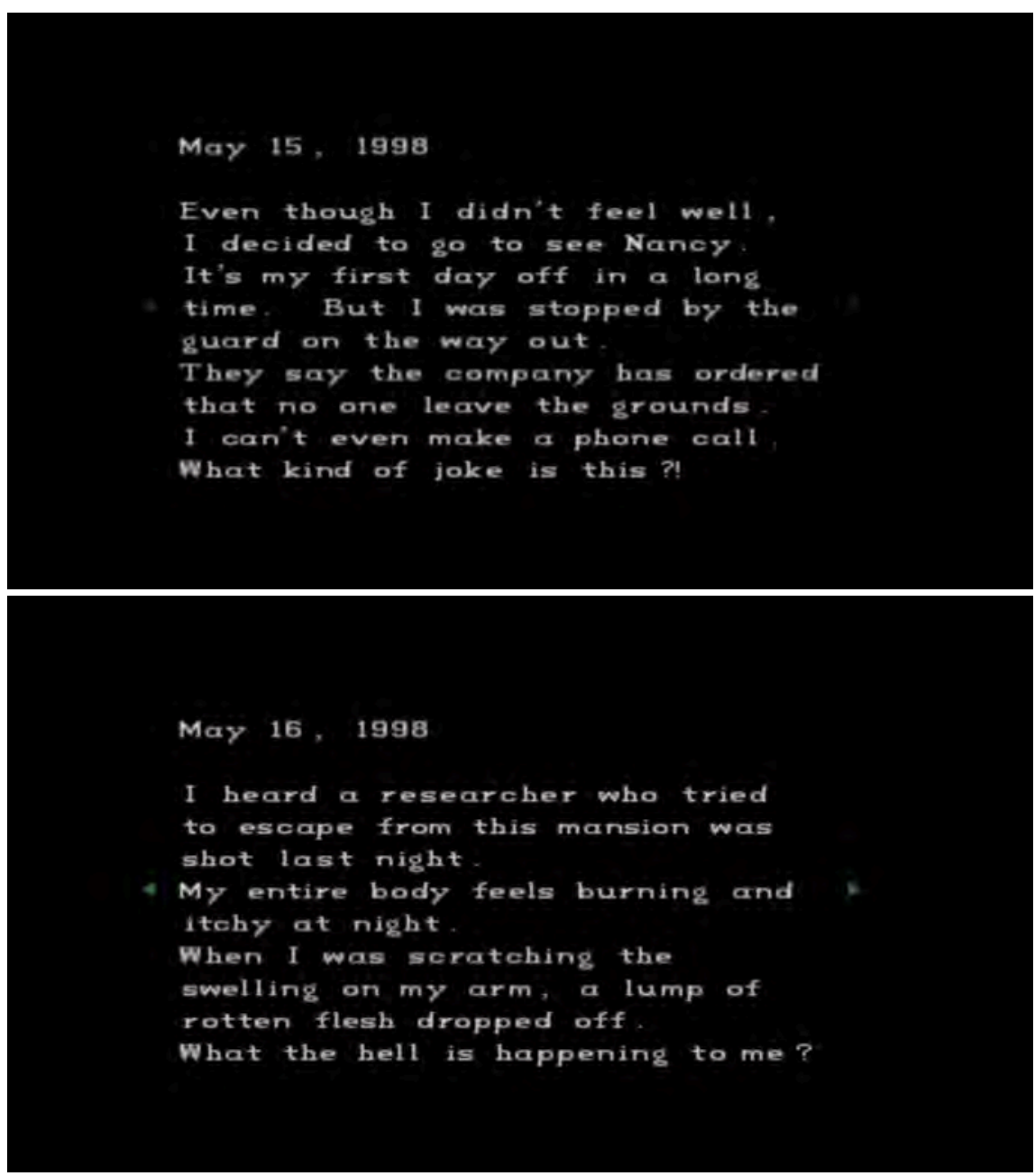

(Figuras 51 e 52: Resident Evil, trechos de um dos diários encontrados no jogo)

Apesar de pertencer ao mesmo gênero que Resident Evil, o que é um indicativo de recorrência e semelhança de procedimentos entre os jogos, Silent Hill se desenvolve de modo bastante distinto. Após a cena de abertura em que ocorre um acidente de carro envolvendo um homem e uma criança, o jogador deve selecionar o modo de jogo para ser levado ao controle da personagem Harry Mason, que acorda após o acidente sem saber onde se encontra sua filha Cheryl; a partir daí, a busca pela menina se dá em meio à névoa e à cidade deserta. $\mathrm{O}$ primeiro indício é um vulto que o jogador jamais consegue alcançar e que leva a um beco: 


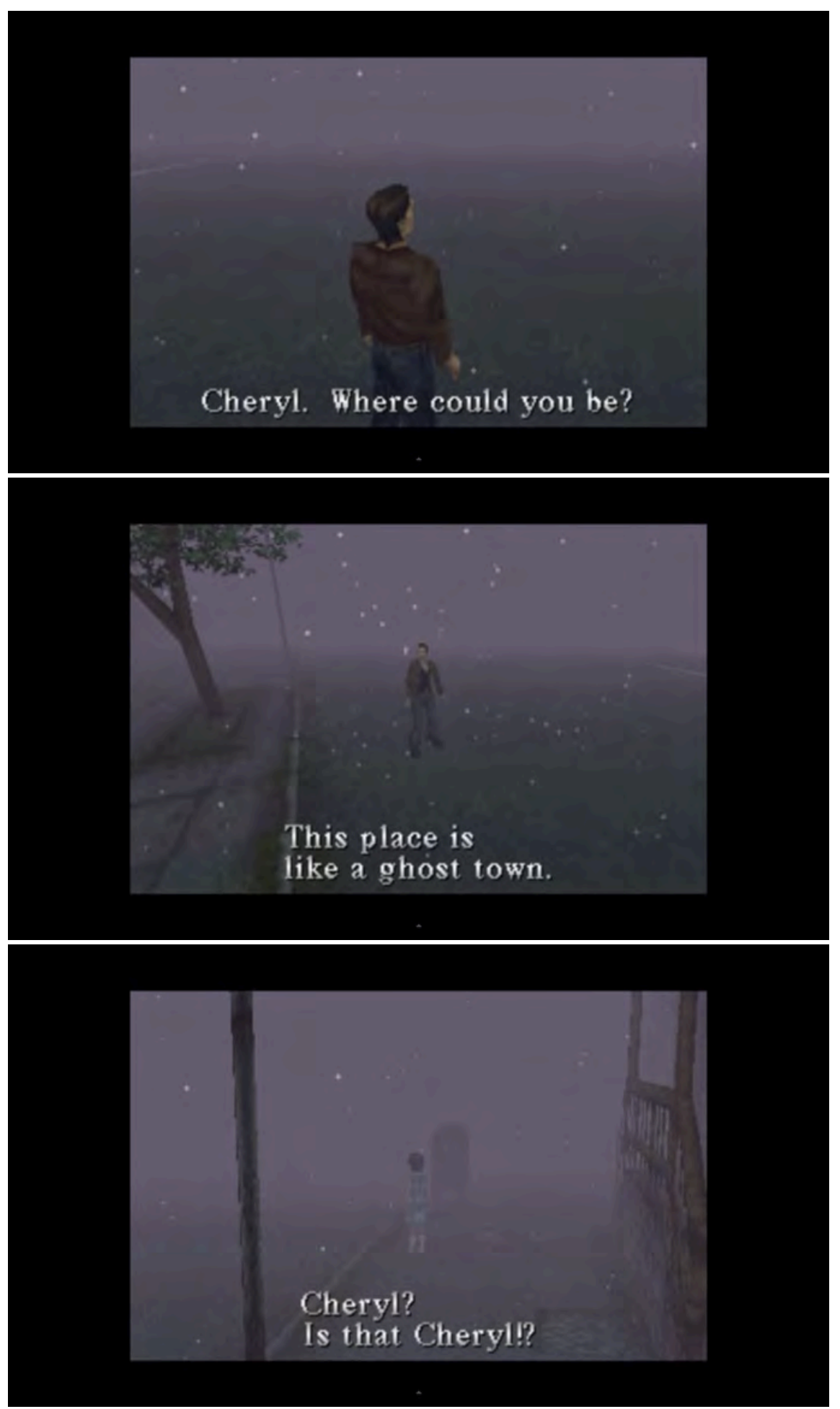




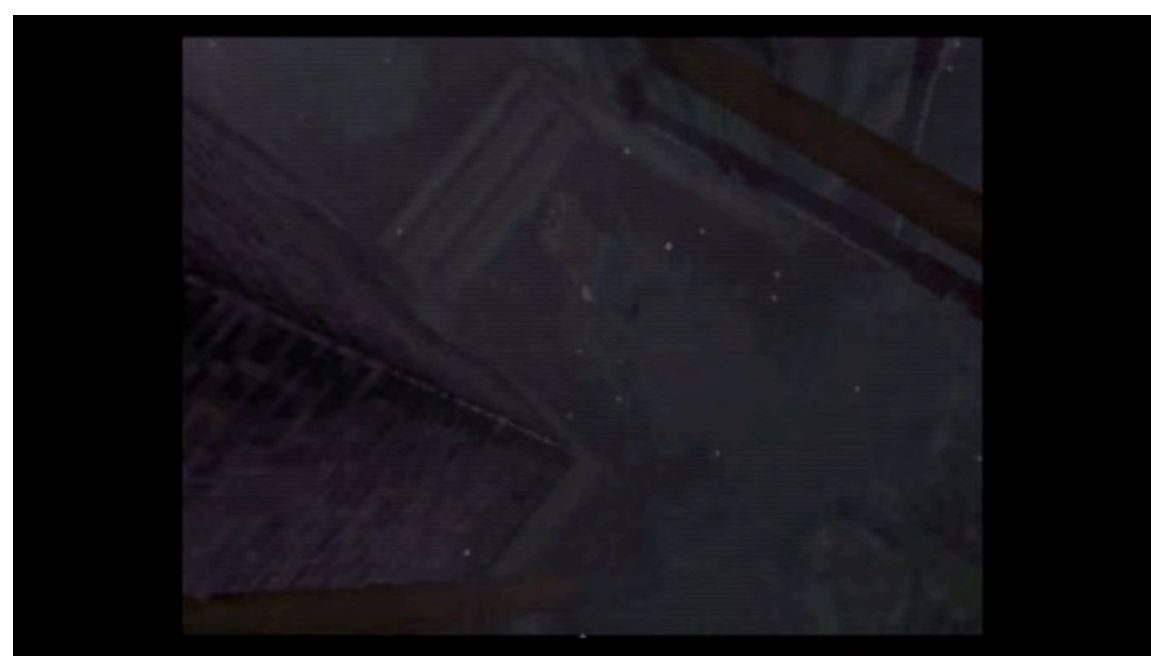

(Figuras 53 a 56: Silent Hill, a procura por Cheryl)

Seguir pelo beco modifica o estado de jogo ${ }^{52}$ (Figuras 57 a 59): tudo fica escuro e sombrio, com corpos expostos; além disso, surgem criaturas bizarras que atacam Harry (neste ponto, é inevitável ser derrotado por elas). Depois do ataque, há uma longa cutscene em que é introduzida a personagem Cybil Bennett, uma policial que entrega uma arma a Harry; a partir daí o jogo "começa" de verdade e o jogador passa a recolher itens, mapas e dicas para resolver os enigmas e avançar, assim como em Resident Evil (o bilhete "To School" dentre as imagens abaixo é encontrado no beco e a folha é reconhecida como pertencente ao caderno de Cheryl):

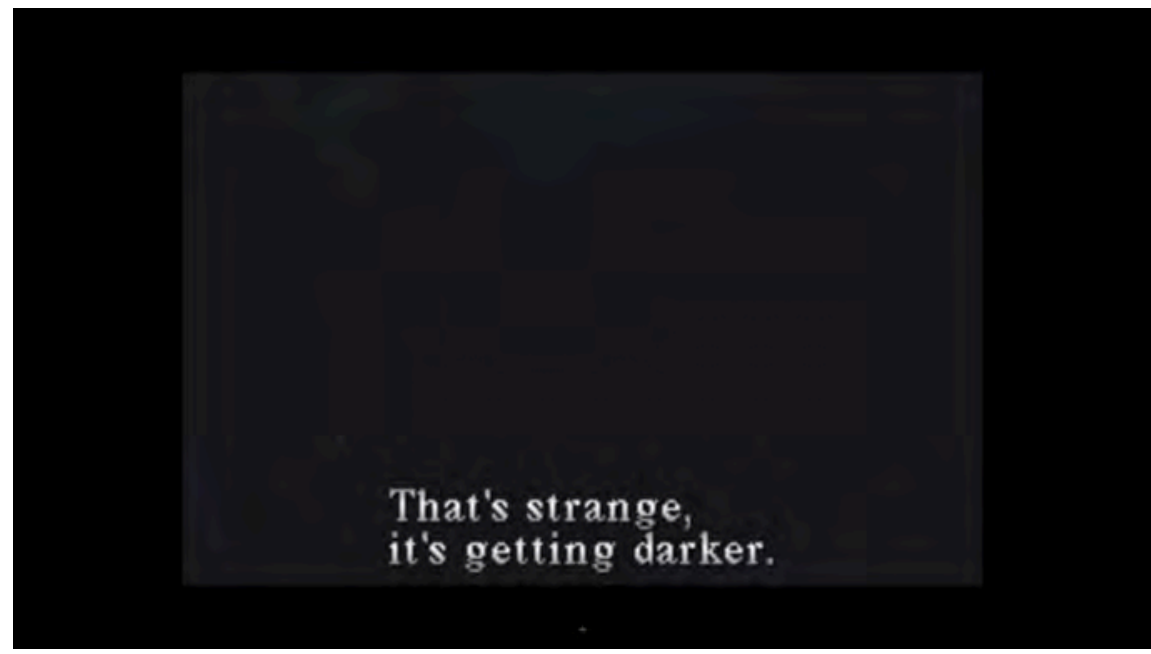

\footnotetext{
${ }^{52} \mathrm{O}$ conceito de estado de jogo foi retirado de Salen e Zimmerman (2004). Como exemplo poderíamos citar o Xadrez, em que cada movimentação feita um jogador altera a organização geral da partida: é impossível movimentar as torres, os bispos, a rainha e o rei logo de início, mas a movimentação de um dos peões pode mudar esse quadro. No caso de jogos como Resident Evil ou Silent Hill, a alteração de estado de jogo diz respeito a alguma modificação feita quando se chega a algum ponto específico ou se faz uso de algum item e que pode, por exemplo, impedir o jogador de retroceder. A alteração de estado de jogo mencionada no texto será melhor explicada adiante.
} 


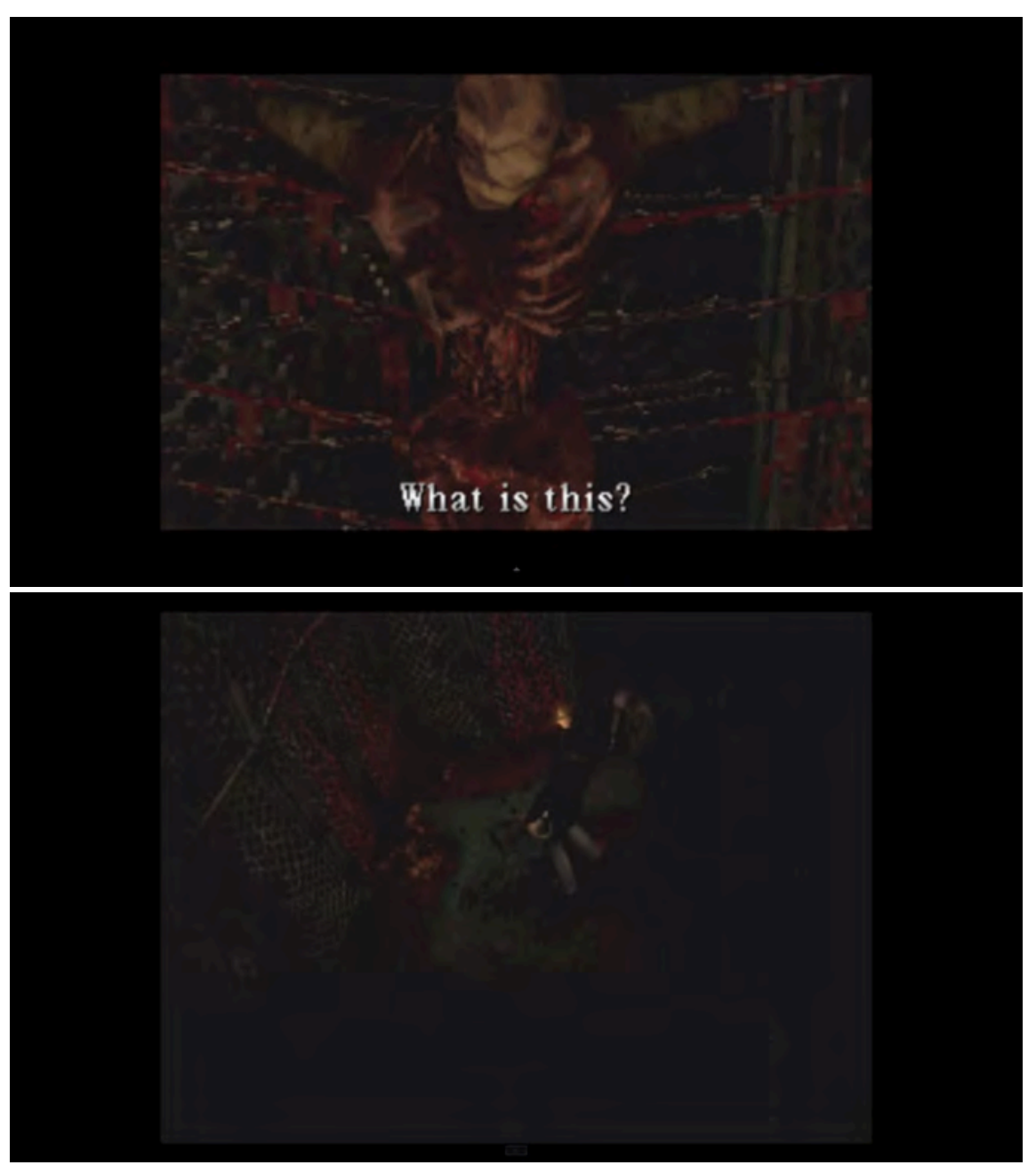

(Figuras 57 a 59: Silent Hill, transição de estado de jogo)

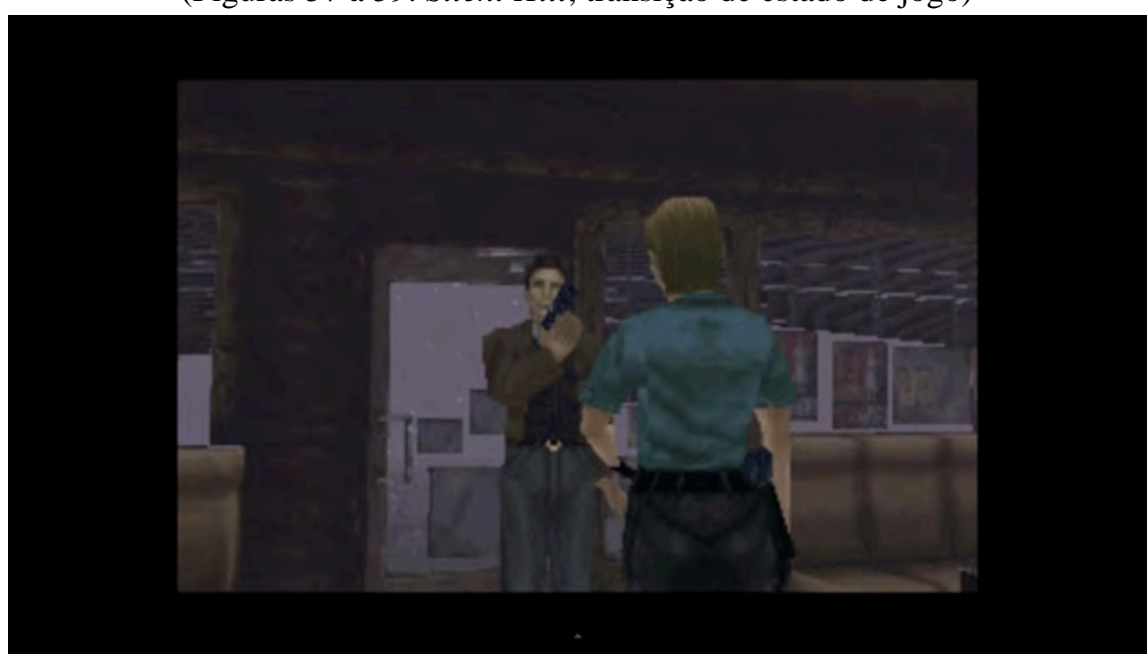



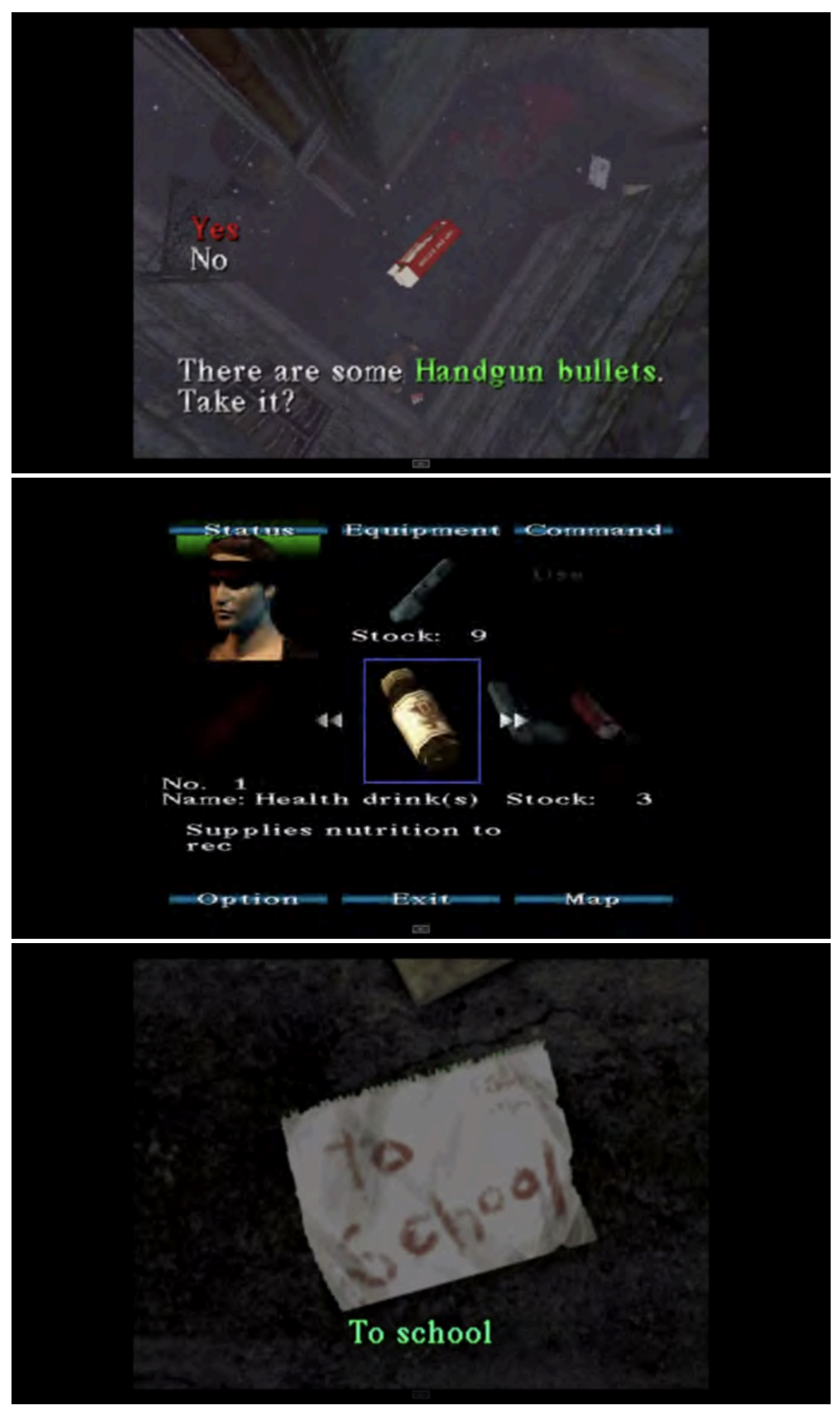


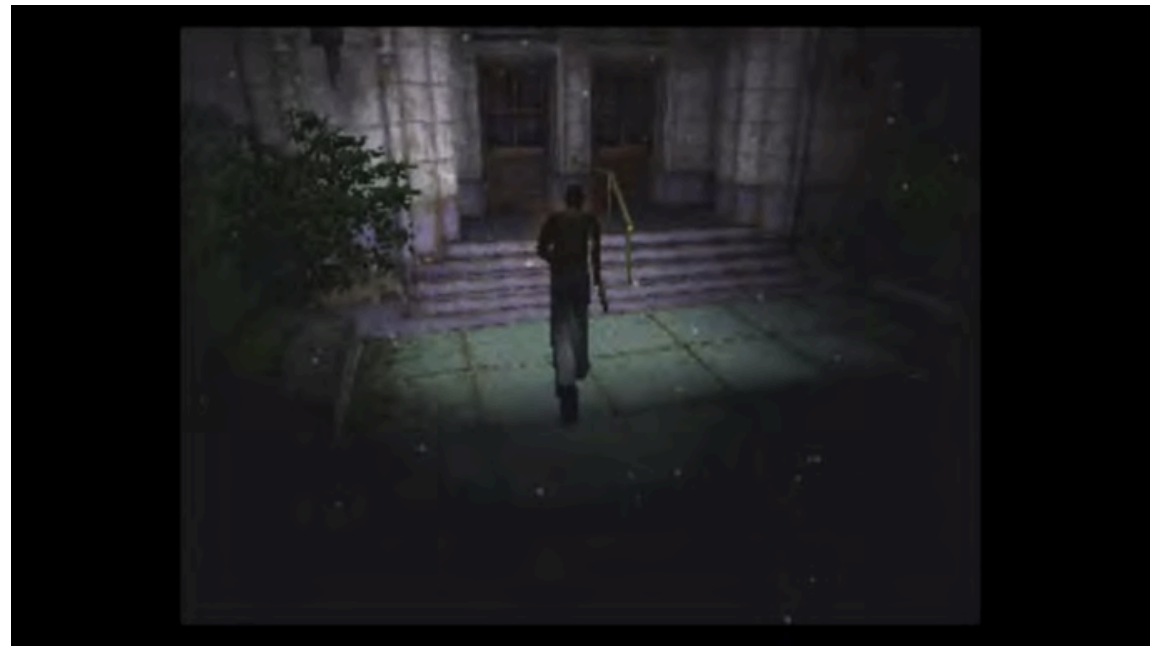

(Figuras 60 a 64: Silent Hill, itens, inventário e exploração)

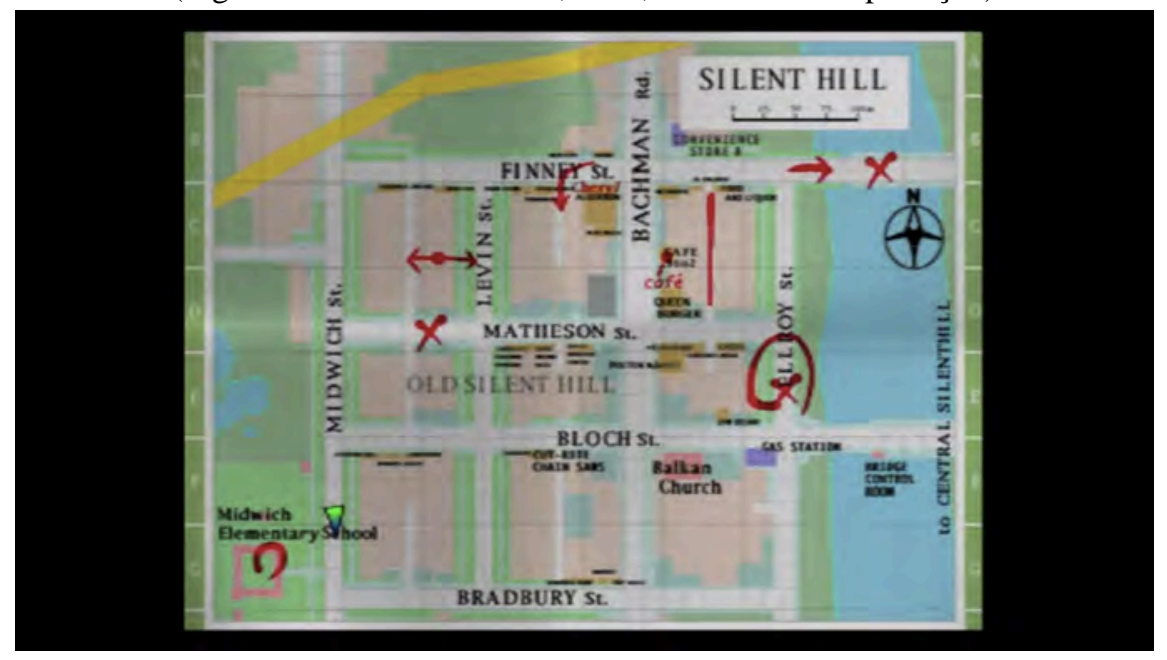

(Figura 65: Silent Hill, mapa marcado)

As marcações (portas trancadas, ruas destruídas e outras informações úteis) que aparecem no mapa logo acima (Figura 65) são feitas automaticamente e de acordo com a progressão no jogo. Esse procedimento, aliado à não limitação de inventário (i.e., é possível carregar quantos itens forem encontrados), torna Silent Hill menos labiríntico que Resident Evil, na medida em que é menos frequente a necessidade de passar repetidas vezes pelos mesmos corredores; os recursos curativos e munição abundante (quando comparado ao caso anterior) também ajudam a diminuir a tensão nesse aspecto específico da exploração. Isso não significa, no entanto, que Silent Hill seja um jogo mais "leve" (menos intenso, se considerarmos a terminologia exposta no Capítulo 2); de acordo com o senso comum a respeito dos dois jogos, trata-se justamente do oposto.

As mudanças de estado de jogo, que marcam a transição para as realidades alternativas (como no caso do beco descrito acima), são frequentes e modificam a percepção do cenário como um todo. Há diversas cenas e eventos que ocorrem ao longo da 
exploração, como monstros que surgem do nada, sons de batidas, choros e outros lugarescomuns presentes também em filmes de terror. A iluminação escassa, advinda quase que exclusivamente da lanterna que o jogador consegue logo após a cutscene com Cybil, é um dos fatores mais importantes de Silent Hill; monstros são atraídos pela luz, obrigando muitas vezes o jogador a desligar a lanterna e ficar imerso na escuridão. A exploração de cada área da cidade funciona como uma espécie de "exorcismo" ${ }^{53}$ : resolver os enigmas da realidade alternativa faz com que o jogador volte à versão normal e encontre as pistas e itens necessários para prosseguir.

As imagens abaixo mostram a escola como o jogador a encontra da primeira vez:

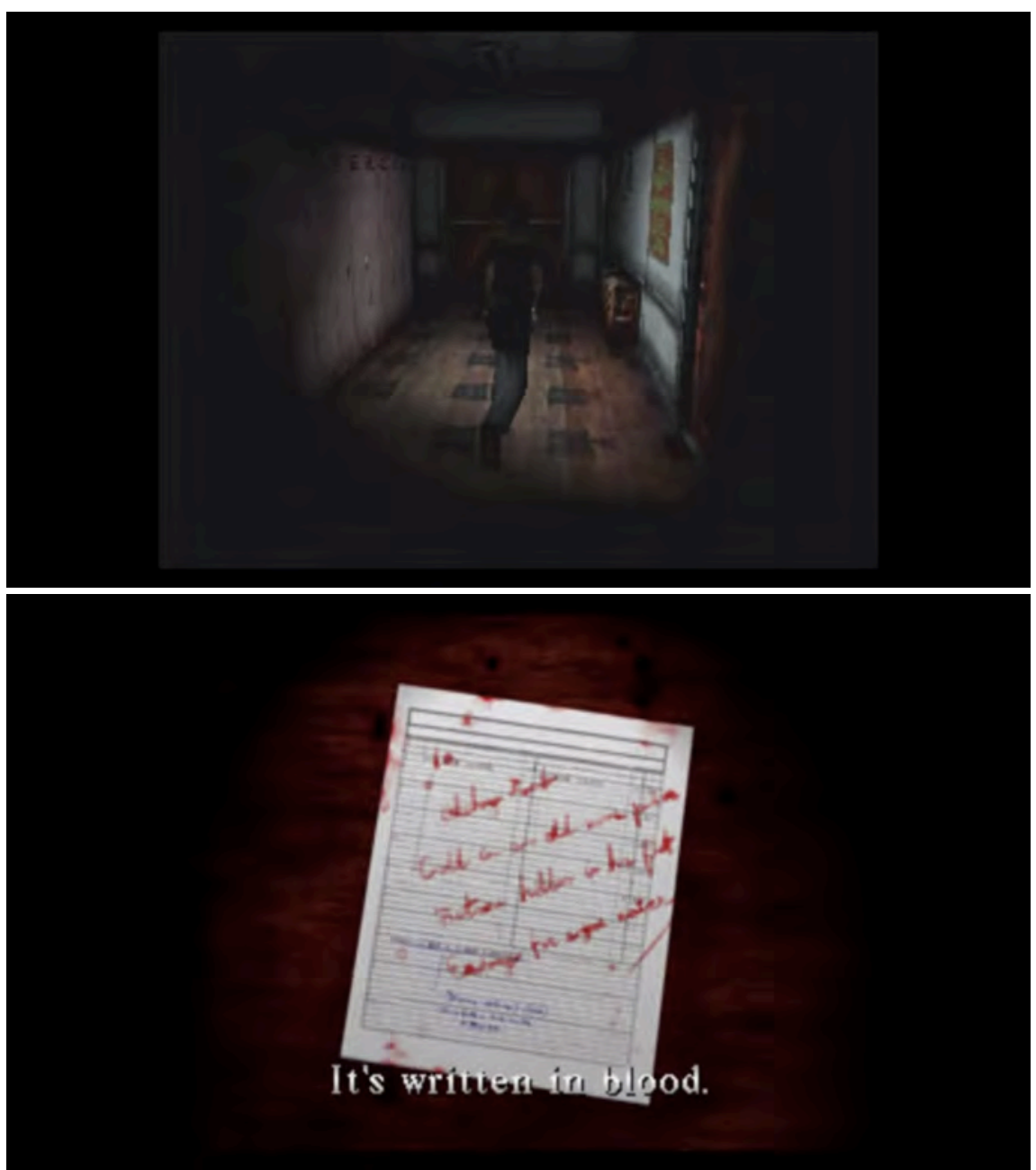

\footnotetext{
${ }^{53}$ A história de Silent Hill tem base no sobrenatural: a situação macabra em que a cidade se encontra tem origem nos pesadelos de Alessa, uma garota que se mantém viva após quase ser imolada em um ritual de magia negra executado anos antes para dar origem a uma espécie de divindade. Nos demais jogos da série, descobre-se que Alessa, na ocasião desses rituais, dividiu sua alma em duas para que eles não pudessem ser completados; uma das metades de sua alma foi materializada em Cheryl, a filha adotiva de Harry (caso se complete uma missão secundária em Silent Hill, descobre-se que a garotinha não é filha biológica). Essas mudanças de estado no jogo fazem com que o jogador vivencie os horrores da mente de Alessa e sua perspectiva sobre a cidade. Maiores detalhes podem ser encontrados nos Anexos deste trabalho.
} 


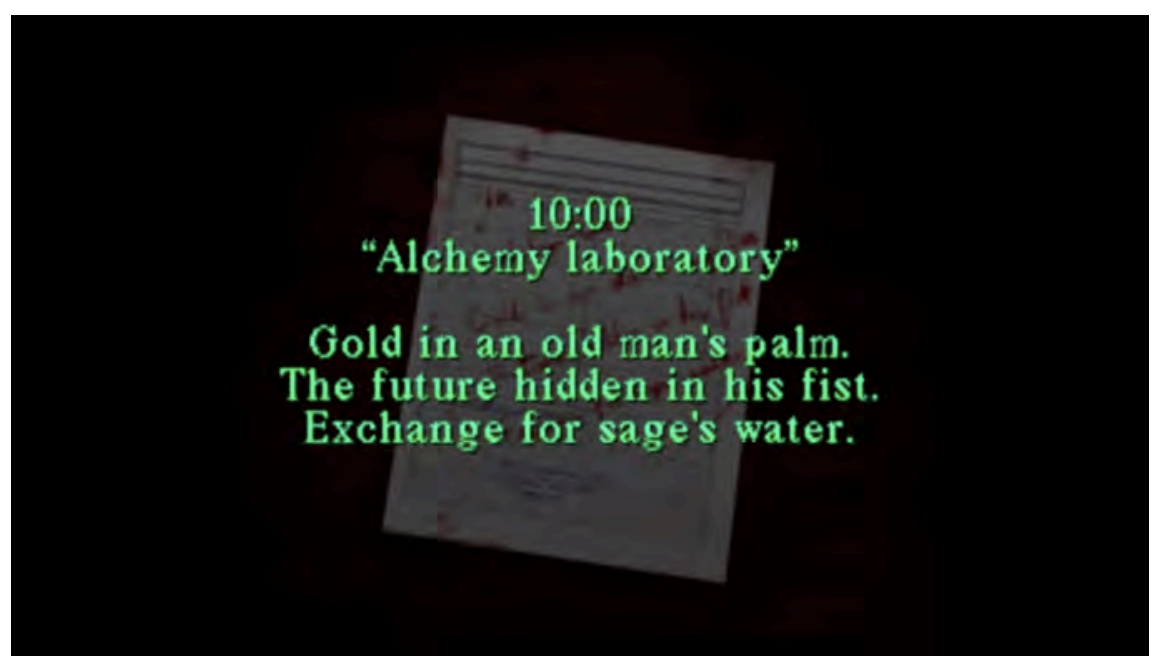

(Figuras 66 a 68: Silent Hill, primeiro estágio da escola)

A realidade alternativa da escola:

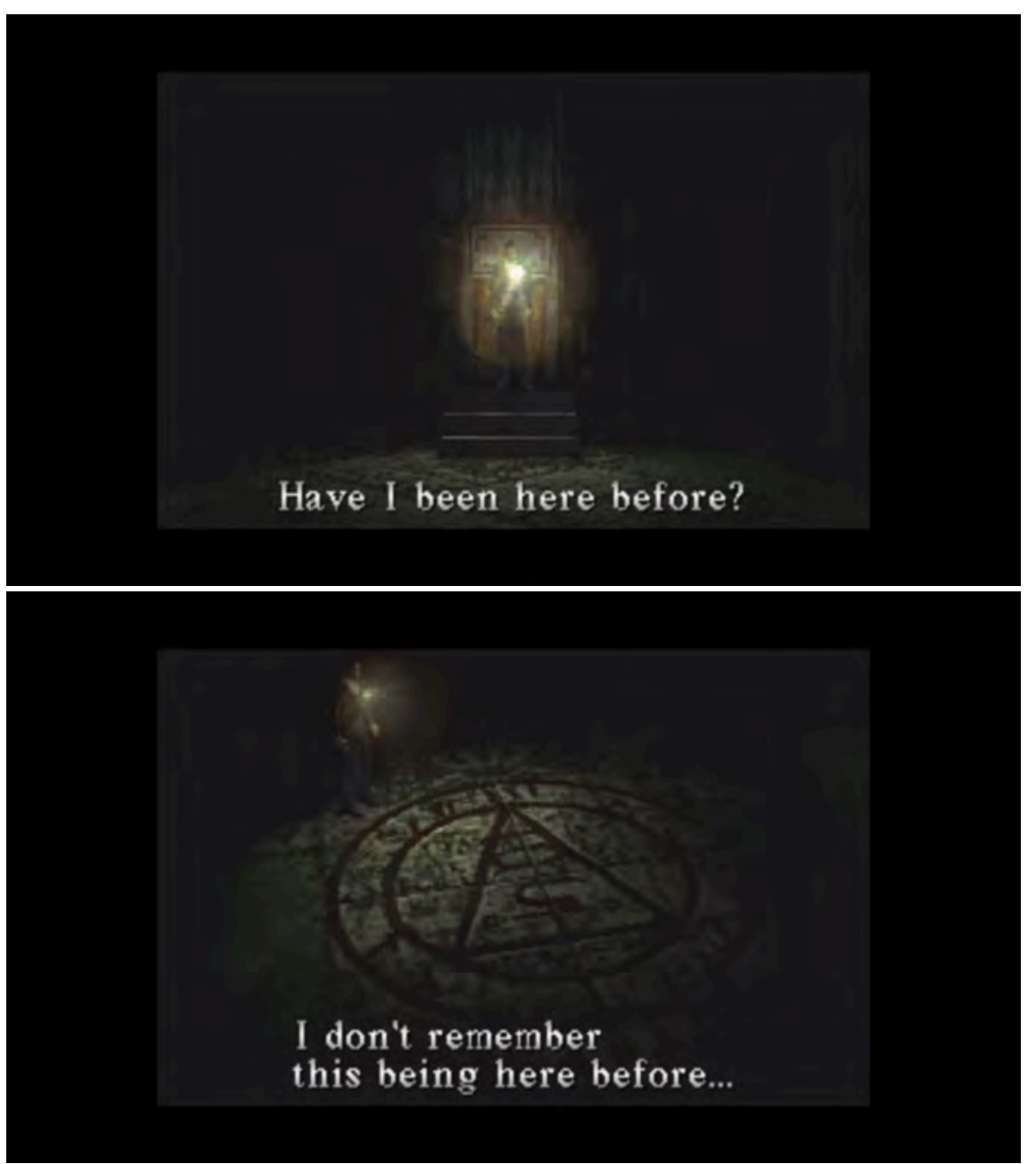




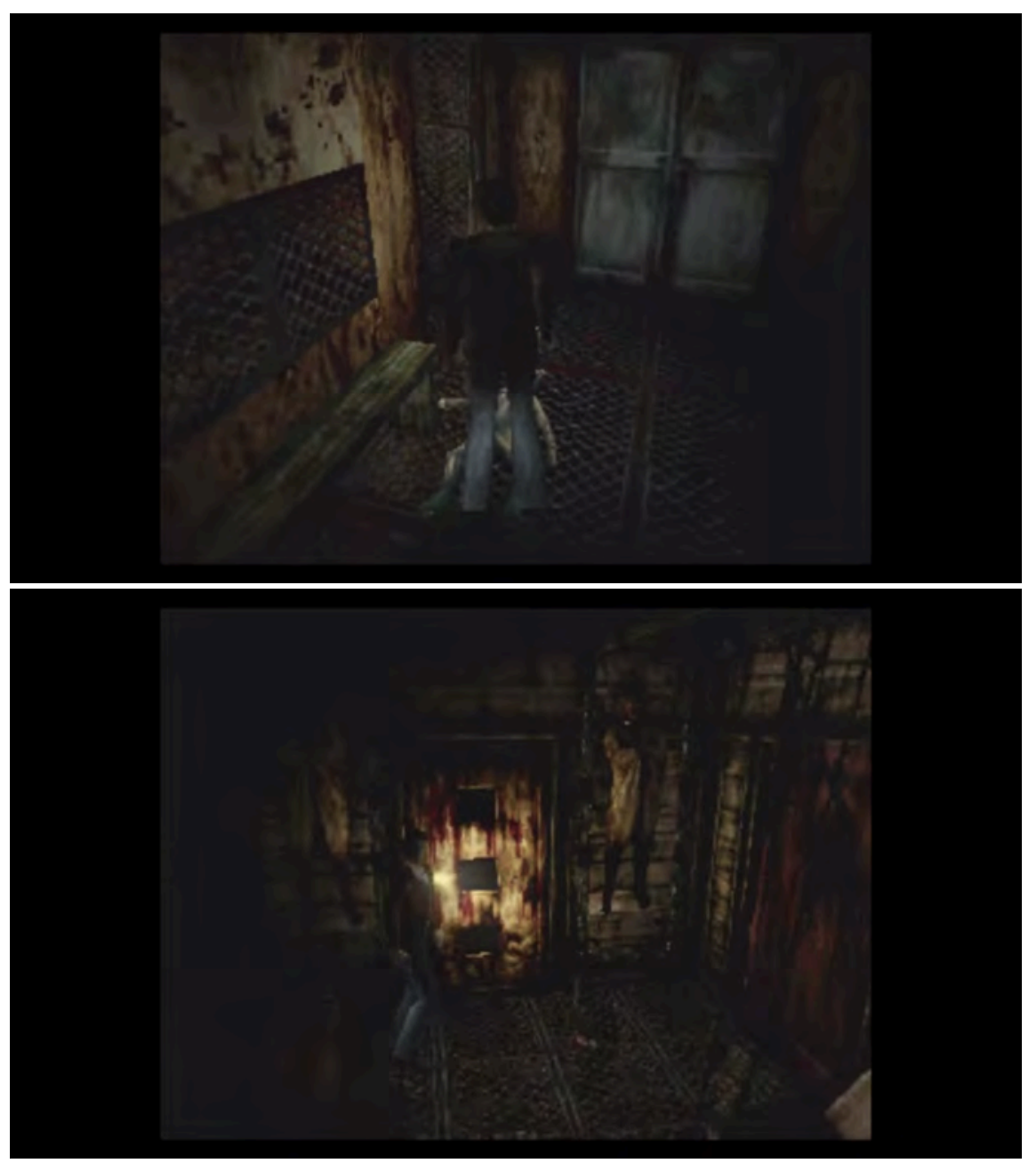

(Figuras 69 a 72: Silent Hill, segundo estágio da escola) A escola após o "exorcismo":

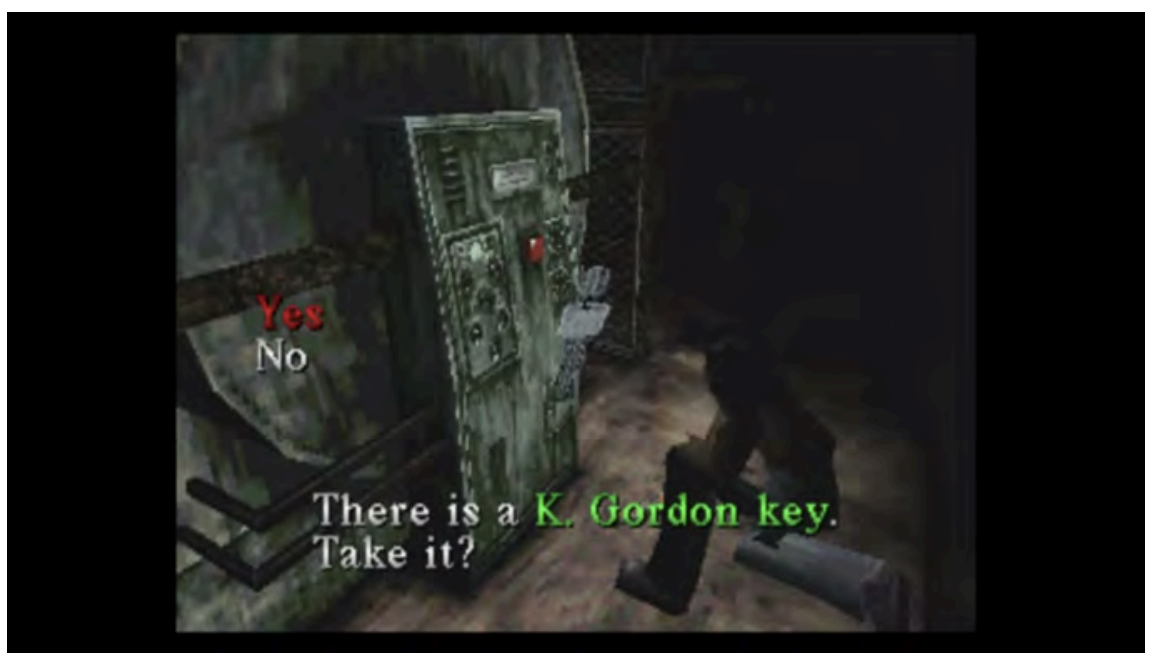




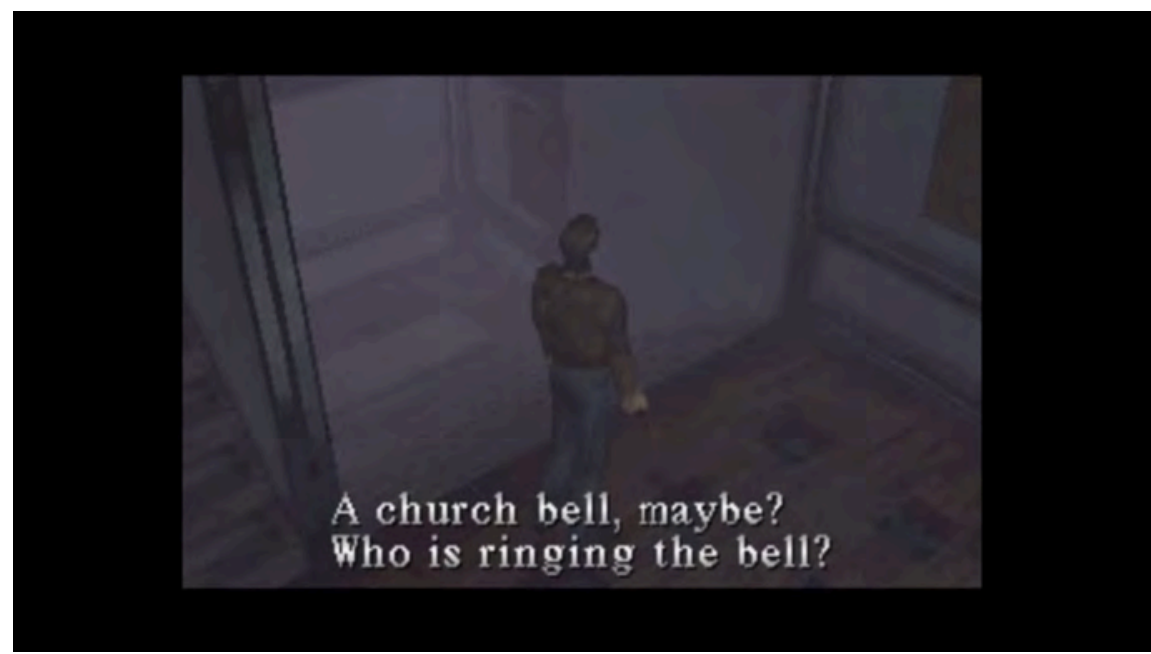

(Figuras 73 e 74: Silent Hill, estágio final da escola com abertura de acesso a outra localidade)

Enquanto Resident Evil se baseia em procedimentos labirínticos e restritivos quanto a movimentação e recursos, Silent Hill cria uma alternância entre estados de jogo com composições de cenário bastante distintas e referências a lugares-comuns e ao tema do macabro, em uma estrutura de pesadelo. A ideia de vivência narrativa trabalhada ao longo desta dissertação é sustentada pelos dois jogos: em vez de simplesmente acompanhar o desenrolar da ação, o jogador a encena com limitações impostas pelos procedimentos para "sentir na pele" o que se passa no plano da narratividade. Ambos os jogos obtêm sucesso em sua proposta de pareamento entre expressão e conteúdo, mas de modos diferentes; como demonstrado no Capítulo 2 a partir do exemplo entre Basquete e Vôlei, os valores que compõem o sistema de cada um apresentam diferenças de ritmo e aspecto cujas origens remontam às relações entre valências no nível tensivo. Em suma, é como se os "genes" tensivos responsáveis pelas diferenças narrativas, temáticas, figurativas e aspectuais do conteúdo desses jogos fossem isolados e suas características fossem implantadas no "DNA" da expressão, relacionando a vivência das personagens à experiência de jogo que incide sobre o corpo do jogador. É a existência dessa relação entre os níveis tensivos e incidência corporal tanto na expressão quanto no conteúdo dos jogos digitais que buscamos demonstrar aqui.

Um dos fatores decisivos para que o contraste dos títulos acima fosse bem sucedido foi o conhecimento dos elementos básicos de seu gênero; é a partir da apreensão de estruturas recorrentes que se torna possível vislumbrar a diferença. Sendo assim, antes de finalizar este capítulo e mergulhar na análise de Final Fantasy XIII, cujo foco será a tradução das bases tensivas do conceito narrativo complexo da vingança em uma forma 
procedural, faz-se mister entender que tipo de jogo está em foco e quais são suas bases constitutivas.

\subsection{O gênero RPG}

RPG é uma abreviação de Role Playing Game, que, como o nome já diz, consiste em um jogo de interpretação de papéis, que podem ser pré-definidos ou de livre escolha, em um pano de fundo ficcional. De acordo com Murray (1997, pp. 115-9), há exemplos de RPGs baseados em Shakespeare, nos quais os participantes devem representar personagens como Othello, Hérmia e Lady Macbeth dentro do universo ficcional de cada peça, com algumas linhas pré-definidas, tais quais o modo de ser, as relações de parentesco, as afinidades e determinadas ações que deverão ser realizadas em pontos específicos da narrativa. Outros RPGs são baseados em universos ficcionais exclusivos, dentre os quais o mais famoso talvez seja Dungeons \& Dragons (TSR, 1974). O pano de fundo ficcional é dado por livros criados exclusivamente para o jogo, e, a partir deles, os participantes podem criar suas personagens e definir um modo de ser próprio para elas. As personagens criadas têm atributos (força, destreza, inteligência etc.) determinados pelas instruções contidas nos livros dos jogos, e vão evoluindo conforme o desempenho dos jogadores na narrativa. Há grupos de RPG que jogam dentro de um mesmo universo por anos, mantendo as personagens desde o início, sem perspectiva clara de um fim para o jogo, pois o que vale em um RPG é a pura imersão em um mundo ficcional. Esse fator leva os RPGs a serem classificados como quase-jogos, de acordo com a definição Juul (2005) e o texto de Ranhel (2009, pp. 12-4). Os resultados quantificáveis aparecem muito mais no desenvolvimento de cada subenredo ou de cada evolução de personagem do que no plano geral da história. Além disso, a impossibilidade de verificação de uma condição de vitória, o que muitas vezes está diretamente ligado à quantificação do resultado, faz parecer que o RPG caminha mais para o teatro de improviso do que para o jogo.

No entanto, o jogo é tratado neste trabalho, como visto, em termos de disposição corporal para jogar, de tornar-se jogador; o que nos interessa aqui é distinguir um modo específico de presença do ser no mundo, uma maneira particular de colocação do sujeito que é evidentemente diferente no teatro de improviso e no RPG: a intenção dos atores em um teatro de improviso é, em última instância, atuar, enquanto os jogadores de um RPG estão dispostos a jogar. Essa disposição específica é essencial para a instauração do espaço 
de jogo e coloca o corpo do jogador como elemento sobre o qual os procedimentos vão agir.

Nesse aspecto, a transposição do RPG para o meio digital foi bastante complexa, tendo em vista que boa parte dos procedimentos têm como base a construção coletiva de enredo e performance por meio do discurso oral - em muitos jogos de RPG, toda ação executada por uma personagem deve ser anunciada por meio da fala do jogador; evidentemente, essa característica não foi adaptada facilmente aos computadores não conectados à rede e aos consoles em que não havia meio eficiente de entrada de texto, levando bastante tempo até que a tecnologia avançasse a ponto de conectar diversos jogadores e permitisse o grau de interação que os RPGs não digitais proporcionavam. Nesse período de "transição", formou-se um gênero próprio, que chamaremos aqui de $R P G$ de console, do qual faz parte Final Fantasy XIII.

As características básicas desse gênero não dizem respeito mais à interpretação livre de papéis, que fica vetada às opções dadas pela programação do jogo: escolha de personagens, linhas de enredo e opções de ação pré-determinadas pelo sistema e acessíveis ao jogador por meio de caixas de texto. Diferente do RPG original, em que os jogadores tinham liberdade quase total para nomear suas ações por meio do discurso e moldar o rumo da história narrada, até então imprevisível, nos RPGs de console o fim - ou os fins, em caso de jogos com múltiplas possibilidades de encerramento - encontra-se dado e as condições de vitória do jogo consistem em avançar pelo enredo até sua conclusão, passando por batalhas contra monstros e personagens-chave da história. Outro desafio proposto é encontrar o caminho certo dentro de mapas com múltiplas rotas que dão acesso a linhas de enredo paralelas opcionais, as chamadas side quests. Geralmente as side quests revelam detalhes do enredo principal ou liberam itens que podem ajudar o jogador a completá-lo. Essa dinâmica de enriquecimento das linhas paralelas opcionais de enredo configuram a característica mais marcante dos RPGs de console, aparecendo como traço distintivo em relação a outros gêneros. Essa dinâmica é bastante similar à que vimos nos jogos de acesso progressivo, sobretudo no caso da busca por documentos e pistas em Resident Evil.

Apesar dessa semelhança estrutural, no RPG, diferente do que ocorre no Survival Horror, os procedimentos não têm por objetivo restringir a ação do jogador e tornar mais penosa sua vivência exploratória; pelo contrário, as relações valenciais de um RPG levam a uma ampliação do espaço e a uma dilatação do tempo de jogo, com consequente 
desaceleração e alívio da tonicidade. Em suma, não se trata de uma estratégia procedural opressiva e sufocante centrada em uma situação problema definida, bem adequada ao Survival Horror, mas de uma experiência cujo foco é a vivência ampla de um universo ficcional muitas vezes gigantesco: não por acaso, o tempo médio gasto para finalizar um jogo como Resident Evil é de quatro horas, enquanto um jogo como Final Fantasy IX requer cerca de 60 horas. Temos uma apreciação "indesejável” de um RPG quando se joga tendo em vista chegar ao final o mais rápido possível, sem fruir das múltiplas possibilidades apresentadas: o jogador não se dispõe, enquanto corpo, a participar do jogo em sua totalidade, buscando apenas as condições de vitória ou derrota, que são menos importantes nesse gênero.

As bases do RPG definidas acima vêm sendo aplicadas aos mais diversos jogos com resultados bastante distintos, cada qual salientando um aspecto e recombinando outros; há muita experimentação e maneiras diferentes de estruturar a experiência do jogador, o que torna necessário examinar como o gênero vem sendo organizado especificamente na série Final Fantasy. O objetivo desse estreitamento analítico é tentar estabelecer qual o horizonte de espectativa de um jogador ao iniciar Final Fantasy XIII, último jogo da série a usar a estrutura de um RPG de console ${ }^{54}$, para que possamos demonstrar no Capítulo 4 como essa espectativa é quebrada e quais os efeitos de sentido daí derivados.

\section{A série Final Fantasy}

Lançado em 1987 para o console NES (Nintendo Entertainment System) pela empresa Squaresoft, Final Fantasy é o primeiro título de uma série que, atualmente, conta com mais de quinze jogos, além de filmes, brinquedos, diversas coletâneas musicais e serve de base para diversos elementos da dita cultura nerd/pop tanto ocidental como oriental. Não faremos aqui um resumo da cronologia de uma série que beira os trinta anos de existência, mas uma breve consideração a respeito de sua posição ao longo da história dos jogos digitais e, também, alguns comentários de sua estrutura básica.

\footnotetext{
${ }^{54}$ Final Fantasy XIV é um RPG Online para múltiplos jogadores (MMORPG) e os jogos Final Fantasy XIII2 e Lightning Returns: Final Fantasy XIII são sequências diretas de Final Fantasy XIII e não pertencem à série principal, cujo próximo título, Final Fantasy $X V$, ainda não tem data de lançamento confirmada.
} 
Final Fantasy é um dos primeiros RPGs digitais gráficos feitos para um jogador e foi lançado tanto no Japão quanto no ocidente. ${ }^{55}$ Permitindo a formação de um grupo com quatro personagens selecionados a partir de um conjunto de classes, Final Fantasy convida a explorar um mundo medievalesco repleto de desafios e desenvolvimentos de enredo por meio de interação básica entre o avatar e os NPCs (Non-playable characters) que povoam o ambiente virtual. Nas imagens abaixo estão a tela de início e seleção de grupo:

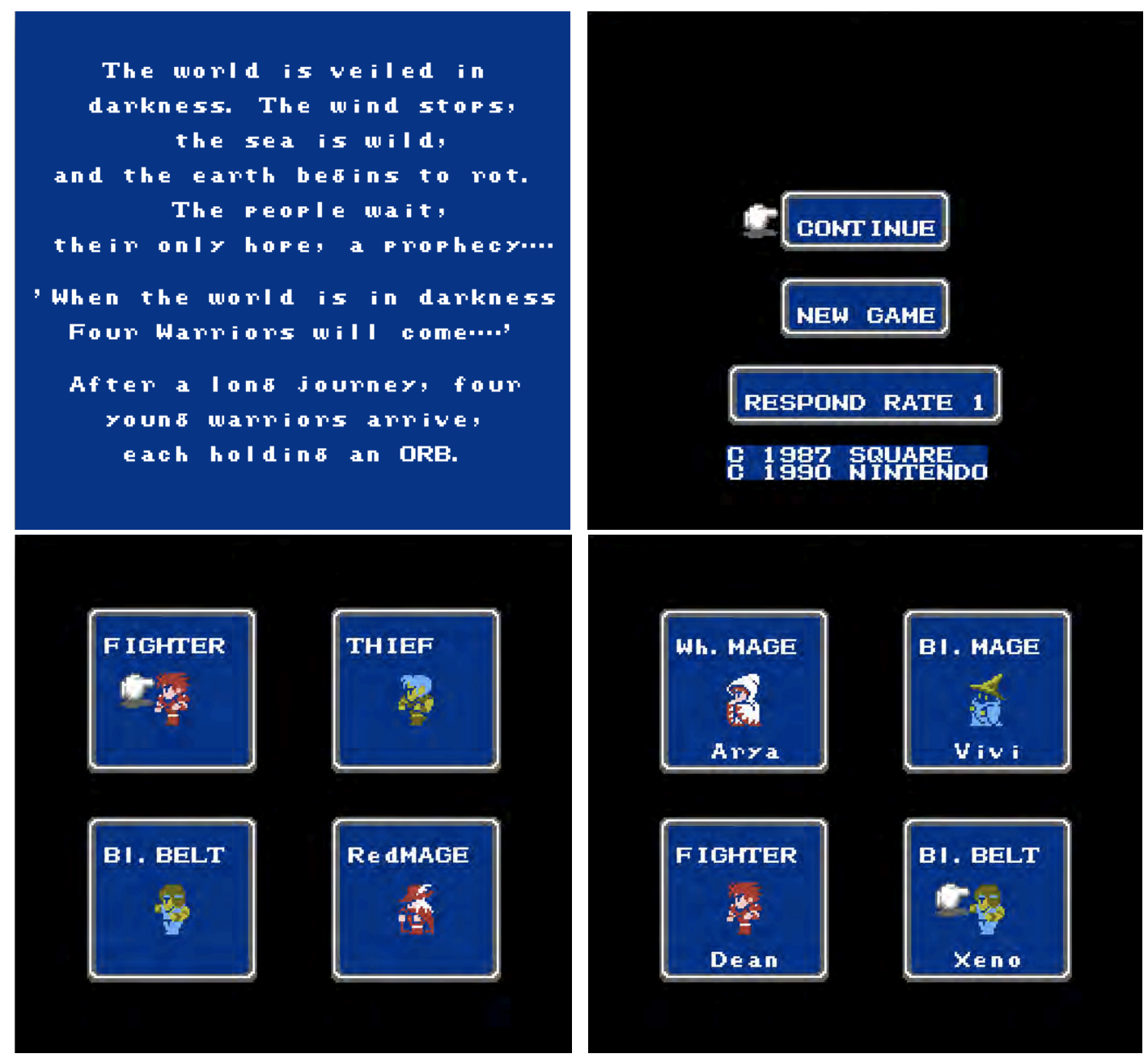

(Figuras 75 a 78: Final Fantasy, telas iniciais)

O enredo é bastante rudimentar se comparado aos padrões estabelecidos atualmente no cenário dos jogos digitais, mas nosso foco não está na avaliação de qualidade do objeto e sim na análise dos mecanismos de narratividade, como apontado acima. Nesse sentido, Final Fantasy estabeleceu diversos padrões que vêm sendo utilizados não só ao longo da série, com diversas variações título a título, mas também por diversos jogos. Vale a pena ressaltar aqui que não se trata de buscar o grau zero ou o início de determinado tipo de

\footnotetext{
${ }^{55}$ A polaridade de mercado Japão versus ocidente é bastante mencionada no campo dos jogos digitais. Há diversos títulos que são lançados apenas em um dos mercados e, até pouco tempo atrás, havia bloqueios de console que impediam o uso de títulos de origem ocidental em consoles orientais e vice-versa.
} 
mecânica, apenas apontar o caráter coletivo da construção de uma narratividade lúdica ao longo da história do desenvolvimento dos jogos digitais, que nas últimas duas décadas, com o advento e popularização dos gráficos em três dimensões para consoles domésticos, sofreu diversas mudanças e variações.

O primeiro aspecto visível da organização estrutural de Final Fantasy é a distinção entre o mapa principal, que representa o mundo em que a história se passa, e as áreas individuais que são por ele englobadas, tais como cidades, vilas, castelos, cavernas etc.; cada um deles tem características próprias e devem ser explorados em momentos diferentes. Andar pelo mapa principal pode gerar encontros aleatórios com inimigos, iniciando os combates (descritos em pormenor mais adiante), enquanto andar pelas cidades ou vilas permite acessar as lojas, interagir com os NPCs e abrir baús; em cavernas ou masmorras há a possibilidade de encontros aleatórios além das interações características das áreas individuais.
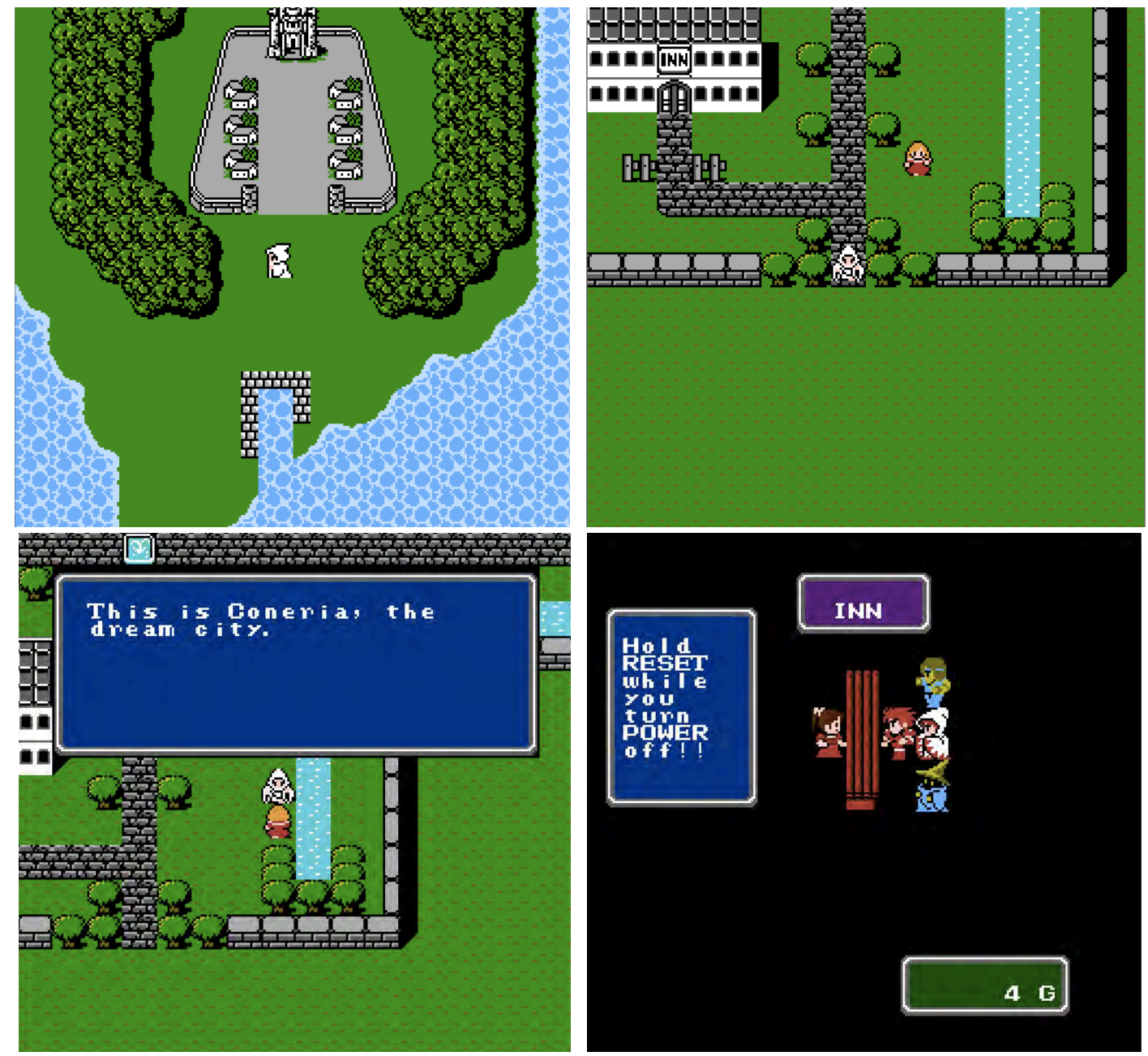

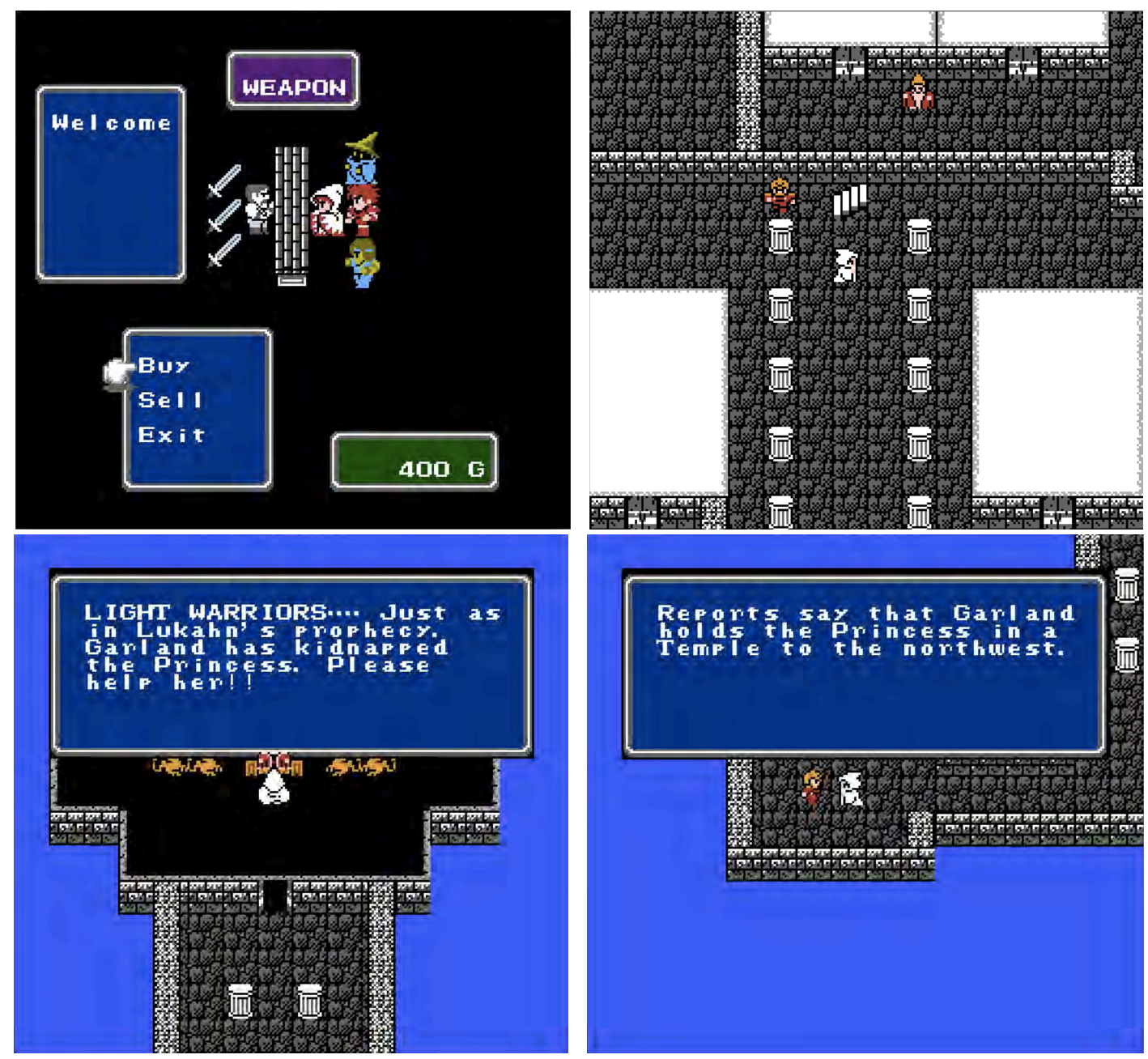

(Figuras 79 a 86: Final Fantasy, navegação pelo jogo)

As mudanças de estado de jogo ocorrem nas áreas individuais, após alguma missão ser finalizada ou um inimigo mais poderoso ser derrotado. Essa característica se manteve nos jogos da série até mesmo após o lançamento de Final Fantasy VII, lançado em 1997 para Playstation. Final Fantasy IX (2000).

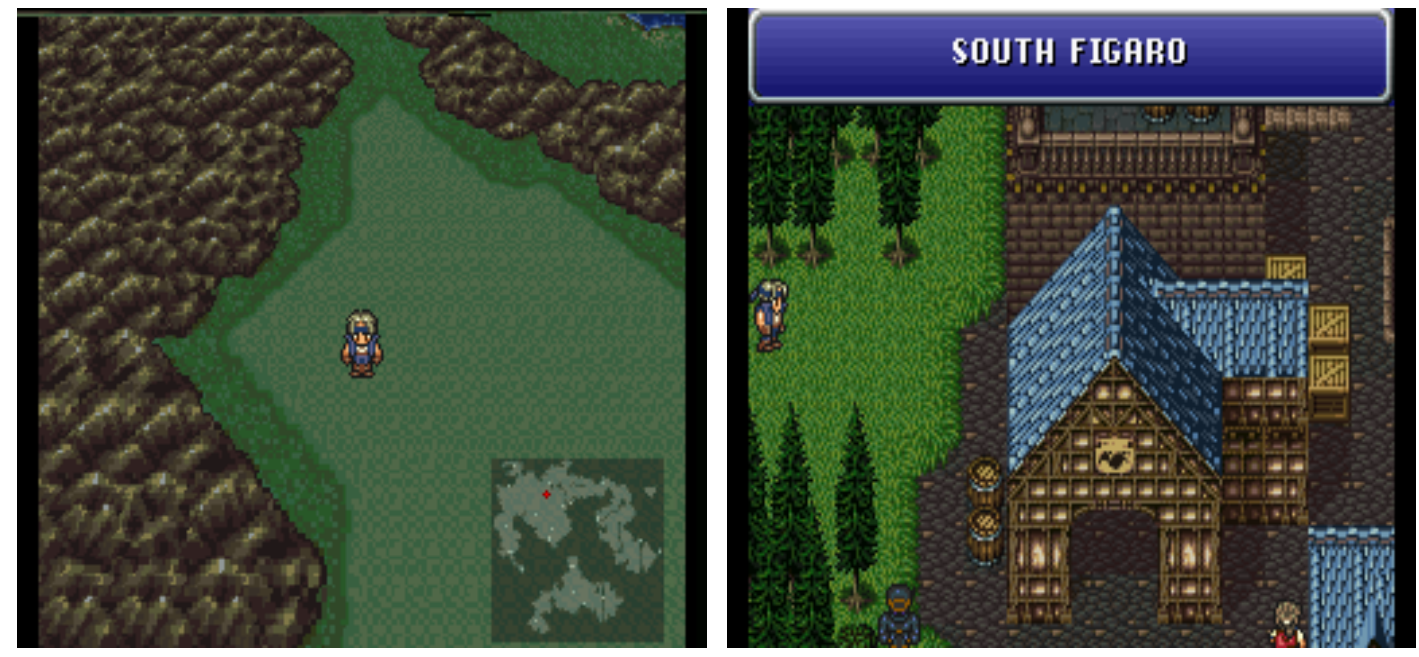

(Figuras 87 e 88: Final Fantasy VI (1994)) 


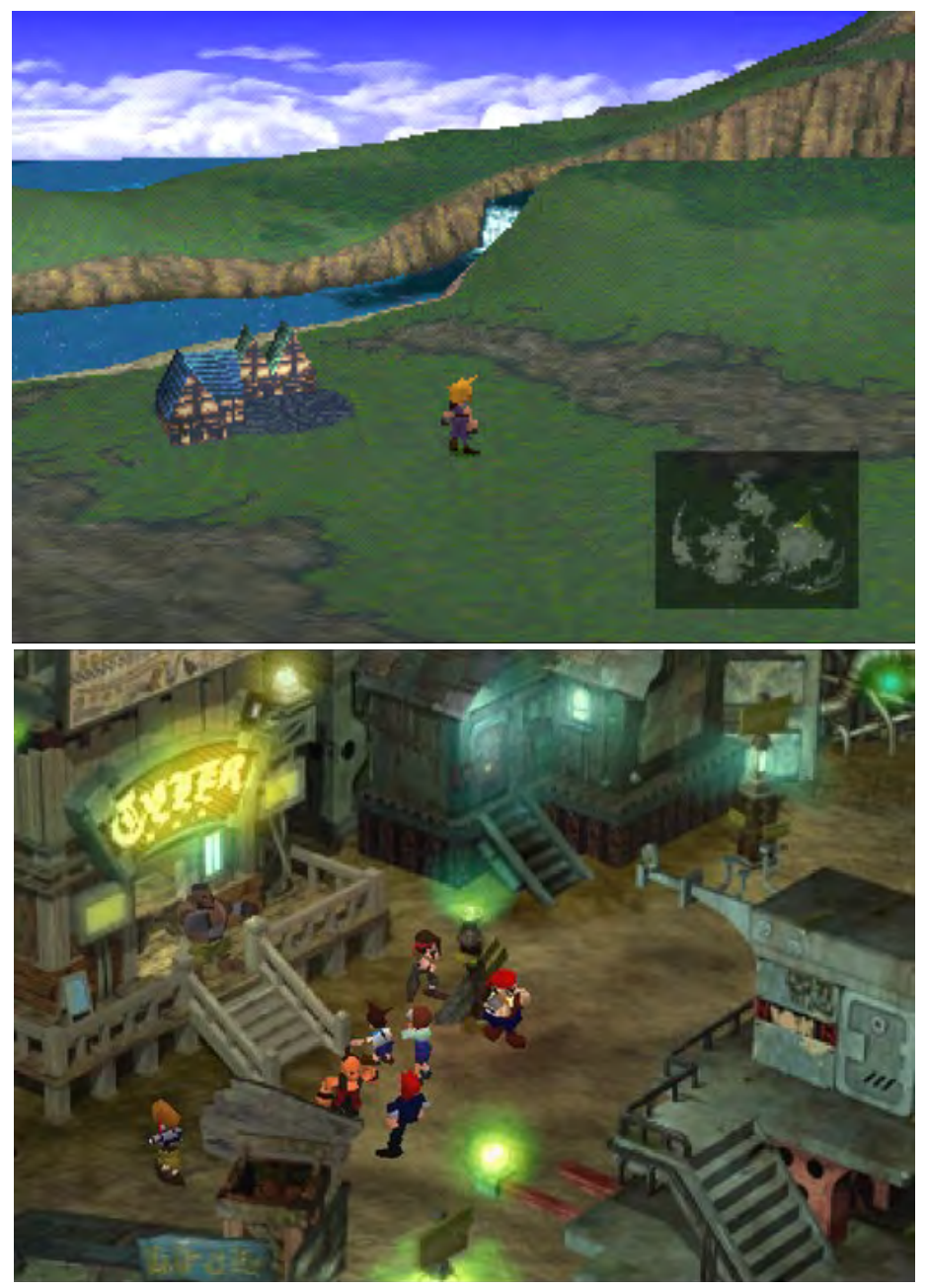

(Figuras 89 e 90: Final Fantasy VII)

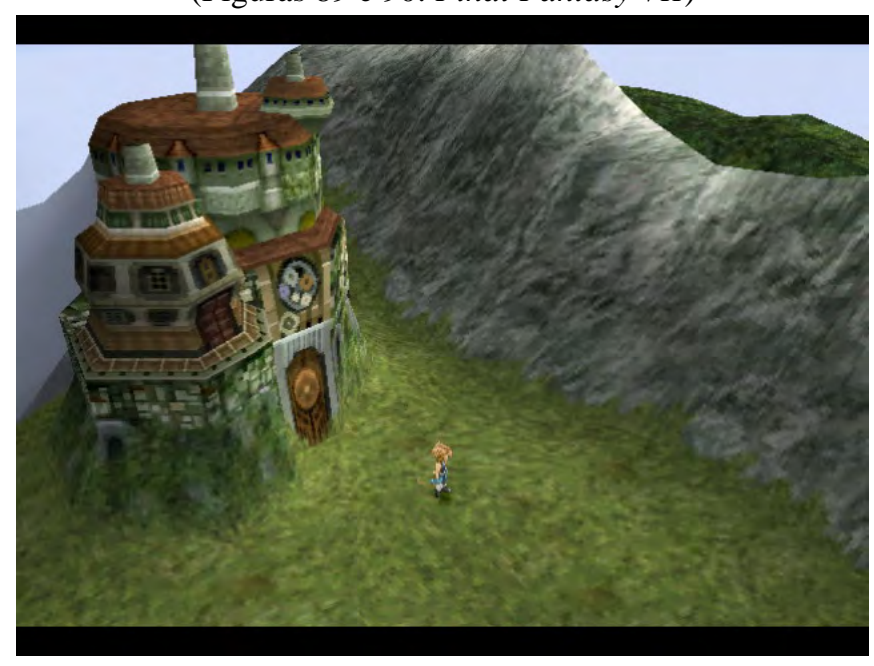




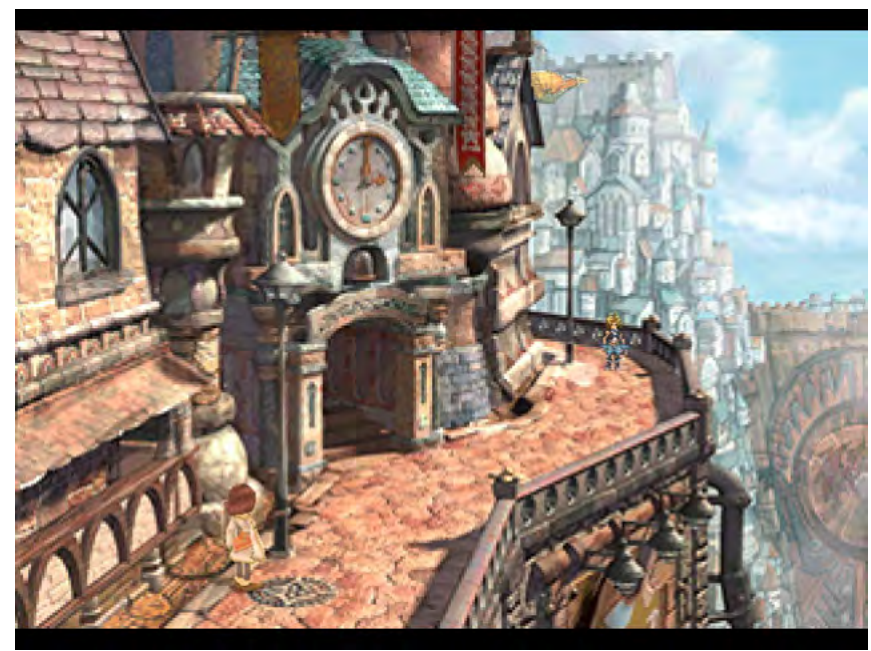

(Figuras 91 e 92: Final Fantasy IX (2000))

A mudança gráfica parece ser o aspecto mais gritante quando comparamos os jogos de diferentes gerações, mas há diversos outros fatores como a unificação dos mercados ${ }^{56} \mathrm{e}$ a utilização do CD como mídia que substituiu o cartucho. Esta última parece ter ser a grande responsável pela mudança narrativa encontrada em Final Fantasy VII: contando com três discos que devem ser utilizados em sequência, a quantidade de informação armazenada aumentou consideravelmente, permitindo um desenvolvimento de enredo mais longo e elaborado que nos demais jogos, além do upgrade gráfico previamente mencionado. Os dois títulos seguintes contam com quatro discos de conteúdo, até que o lançamento de Final Fantasy X (2001), para Playstation 2, introduziu o DVD, permitindo armazenar ainda mais informação do que o sistema com quatro CDs. Além disso, duas características importantíssimas foram adicionadas à série: a dublagem nas cutscenes e a eliminação da alternância entre o mapa principal e as áreas individuais.

No caso de Final Fantasy X, o desenvolvimento exploratório é bastante linear e compreende, basicamente, andar em linha reta durante boa parte do jogo. Embora isso pareça contrário ao gênero, há um pareamento entre expressão e conteúdo bastante evidente: o enredo trata da peregrinação da evocadora ${ }^{57}$ Yuna e de seus guardiões, que

\footnotetext{
${ }^{56}$ Devido às diferenças entre mercado japonês e ocidental, a numeração dos títulos variava. Enquanto no Japão havia seis títulos, três lançados para NES e três para o SuperFamicon, no ocidente foram lançados apenas três: Final Fantasy, para NES, e Final Fantasy IV e VI, para SNES, renomeados como Final Fantasy II e III, respectivamente. Retomaremos o assunto mais adiante quando tratarmos do relançamento multiplataforma dos títulos.

${ }^{57}$ Summoner, em inglês. Trata-se de uma classe bastante comum na série Final Fantasy. Os Summoners são as personagens capazes de trazer criaturas mágicas para o campo de batalha e controlá-las. A opção de tradução por "evocadora" em detrimento de "invocadora" tem razão etimológica: invocar remete a "chamar pra dentro", enquanto "evocar" seria "chamar para fora"; além disso, em Final Fantasy XIV: A Realm Reborn um dos itens exclusivos para usar como Summoner é chamado de Evoker's Robe.
} 
devem seguir por todos os templos de Yevon (a instituição religiosa de Spira, o mundo ficcional em que se passa a história) de modo a ganhar o poder necessário para derrotar a entidade maligna conhecida como Sin, que assola o mundo. Após a peregrinação ter fim, o jogador ganha acesso a uma aeronave (algo bastante comum em todos os jogos da série Final Fantasy) e pode revisitar as localizações pelas quais passou e até mesmo encontrar algumas novas, garantindo a sensação de acesso progressivo e alinearidade. As imagens abaixo (Figuras 93 a 96) mostram que não há diferença entre cidades e estradas (que corresponderiam ao mapa principal, por exemplo):
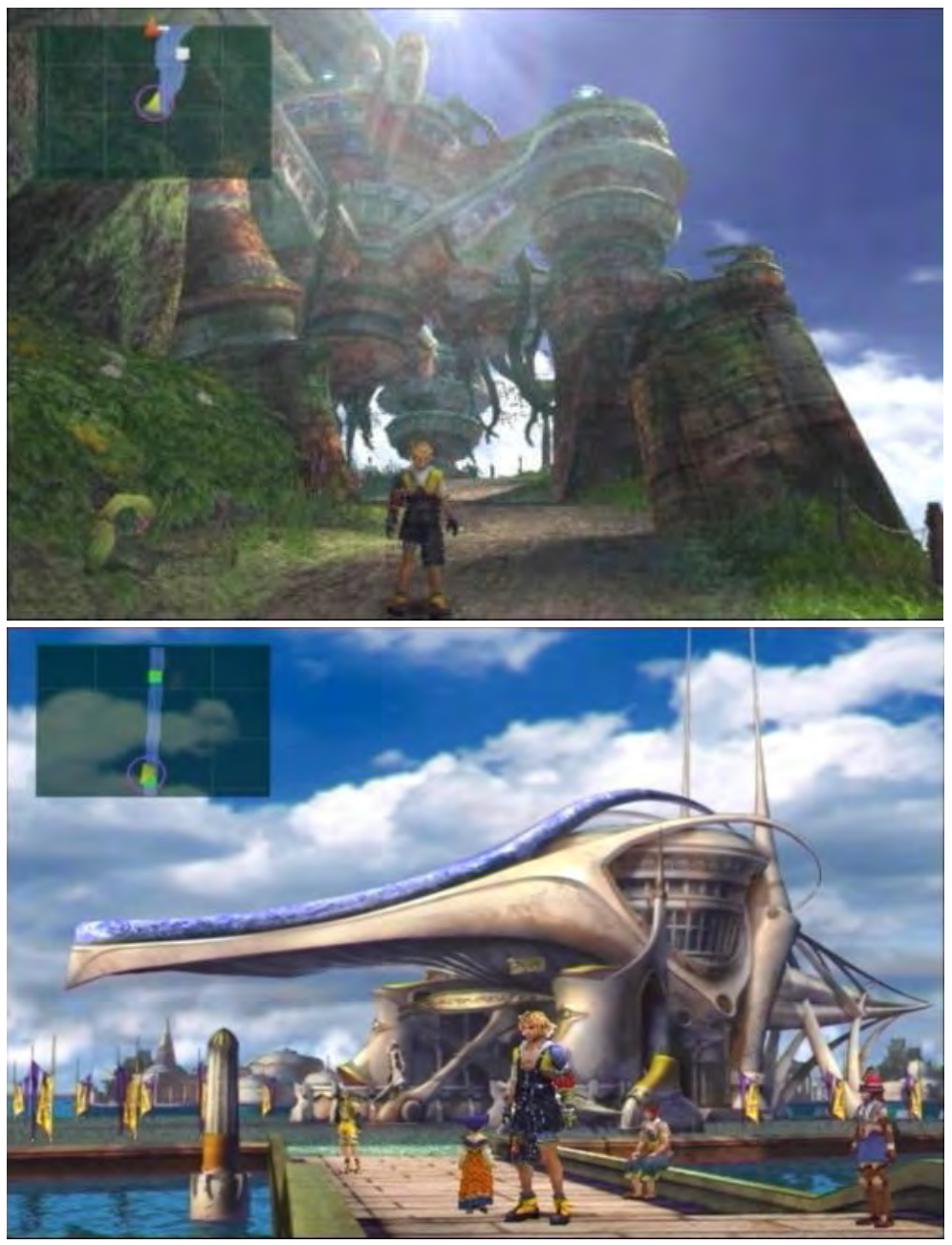

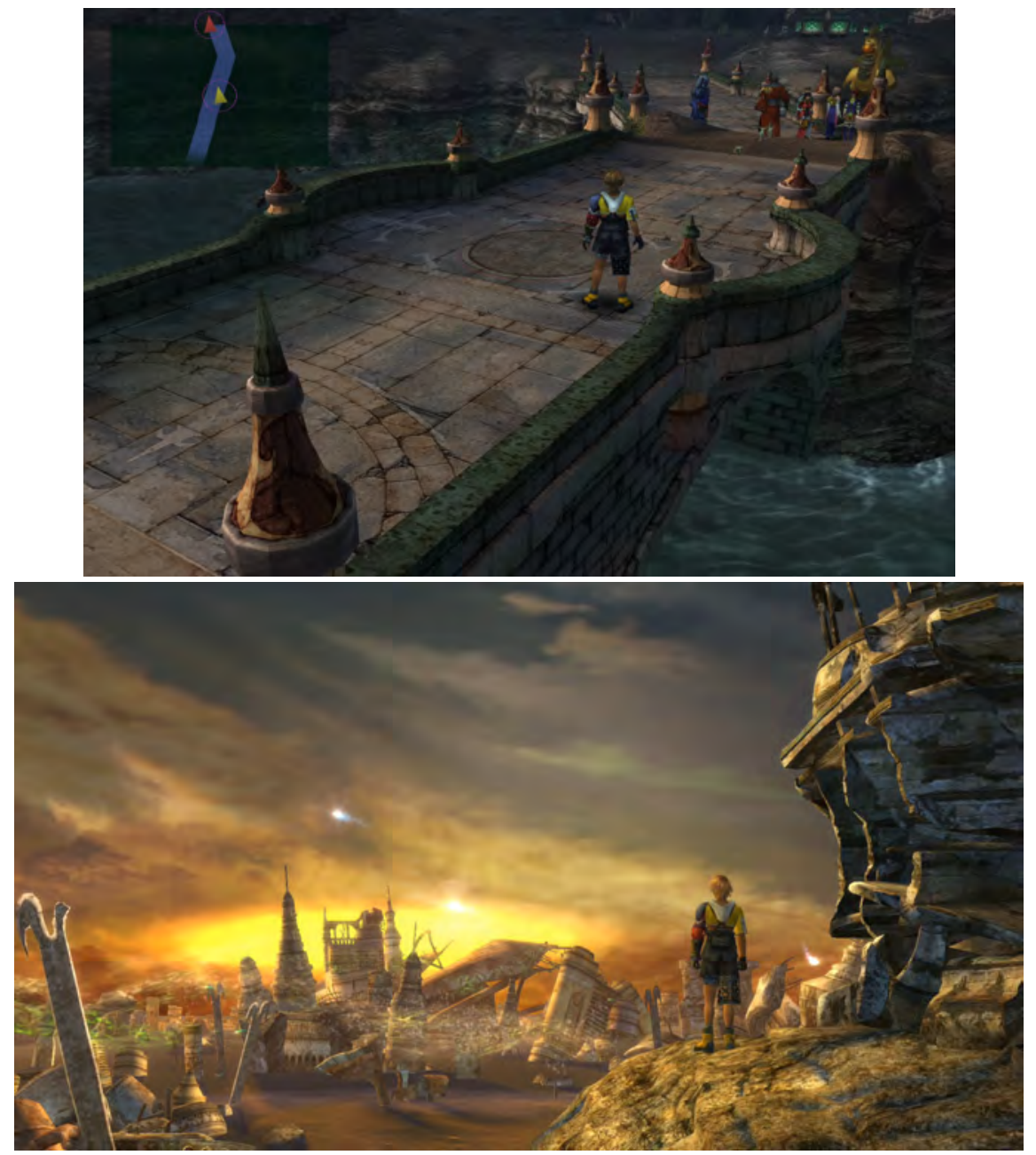

(Figuras 93 a 96: Final Fantasy X)

Em Final Fantasy XII (2006) não há linearidade nem mesmo no início do jogo; nesse título, a estrutura de exploração expansiva em várias direções que era associada ao mapa principal nos jogos anteriores a Final Fantasy $X$ é transposta em um complexo de cenários e ambientes interligados continuamente. Nas imagens abaixo (Figuras 97 a 100) é possível ver os ambientes amplos e um mapa de área similar aos de Resident Evil e Silent Hill, que apresentam cenários contínuos:
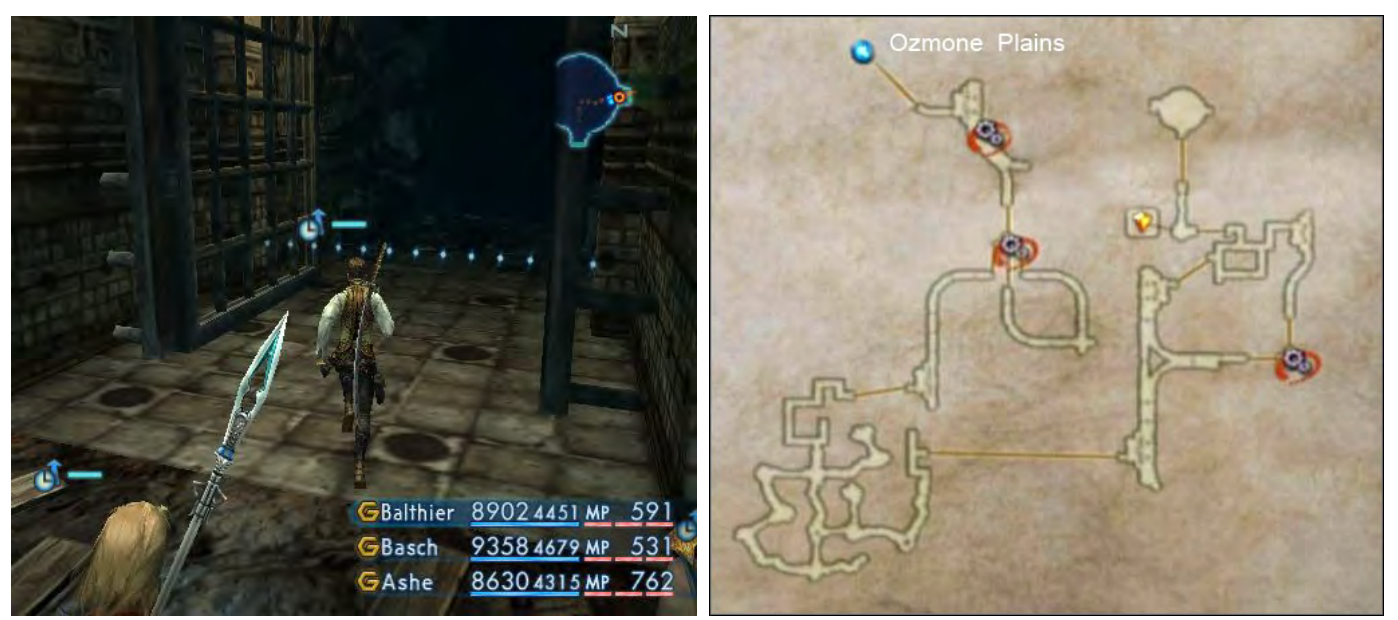


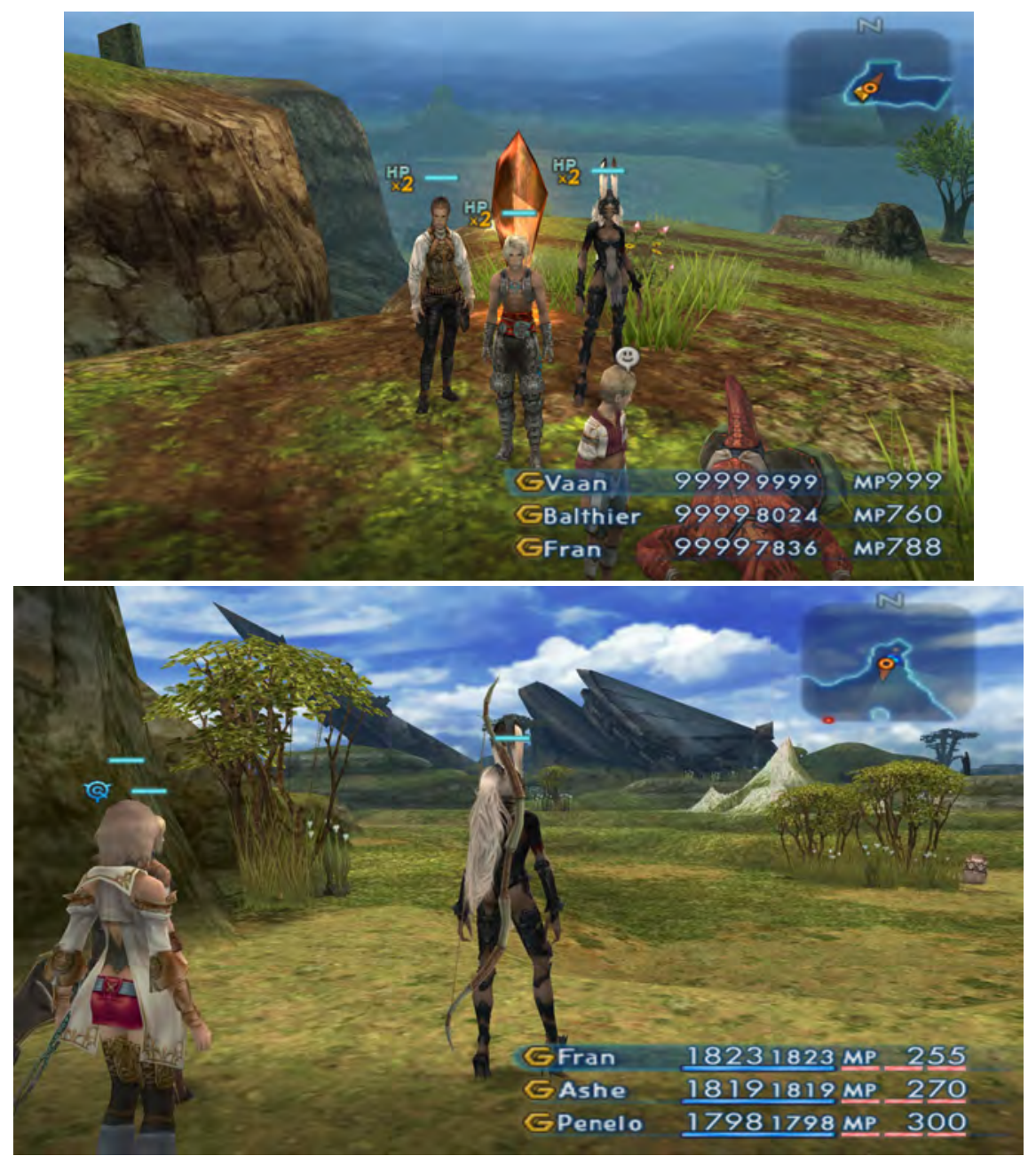

(Figuras 97 a 100: Final Fantasy XII)

Outro aspecto que transcende os títulos da série é o sistema de combate, feito por turnos. Com exceção das versões online e de Final Fantasy XII, em todos os outros jogos da série a transição para o modo de batalha ocorre da mesma maneira: ao percorrer o mapa principal (ou as áreas entre cidades, no caso de Final Fantasy X) e as masmorras, o jogador está sujeito a um encontro aleatório, sinalizado por um efeito sonoro e/ou alguma indicação gráfica na tela; a partir daí, a tela de combate é mostrada: 


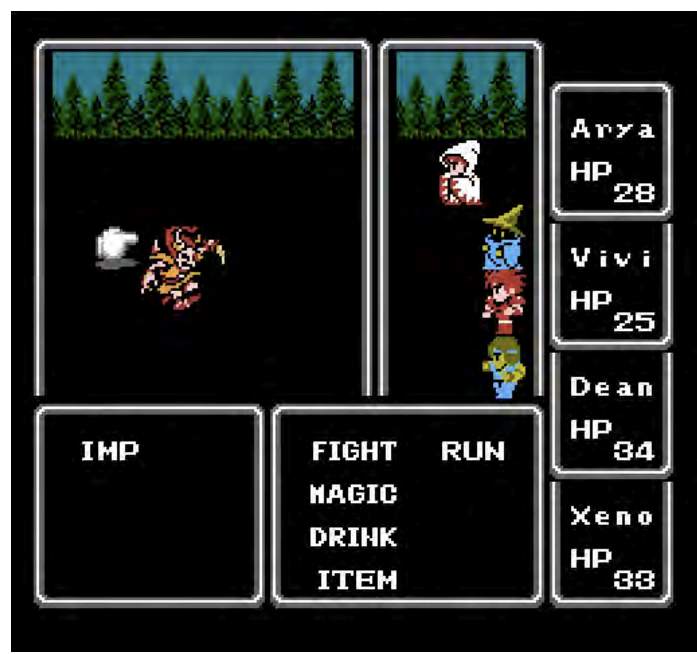

(Figura 101: Final Fantasy, tela de batalha)

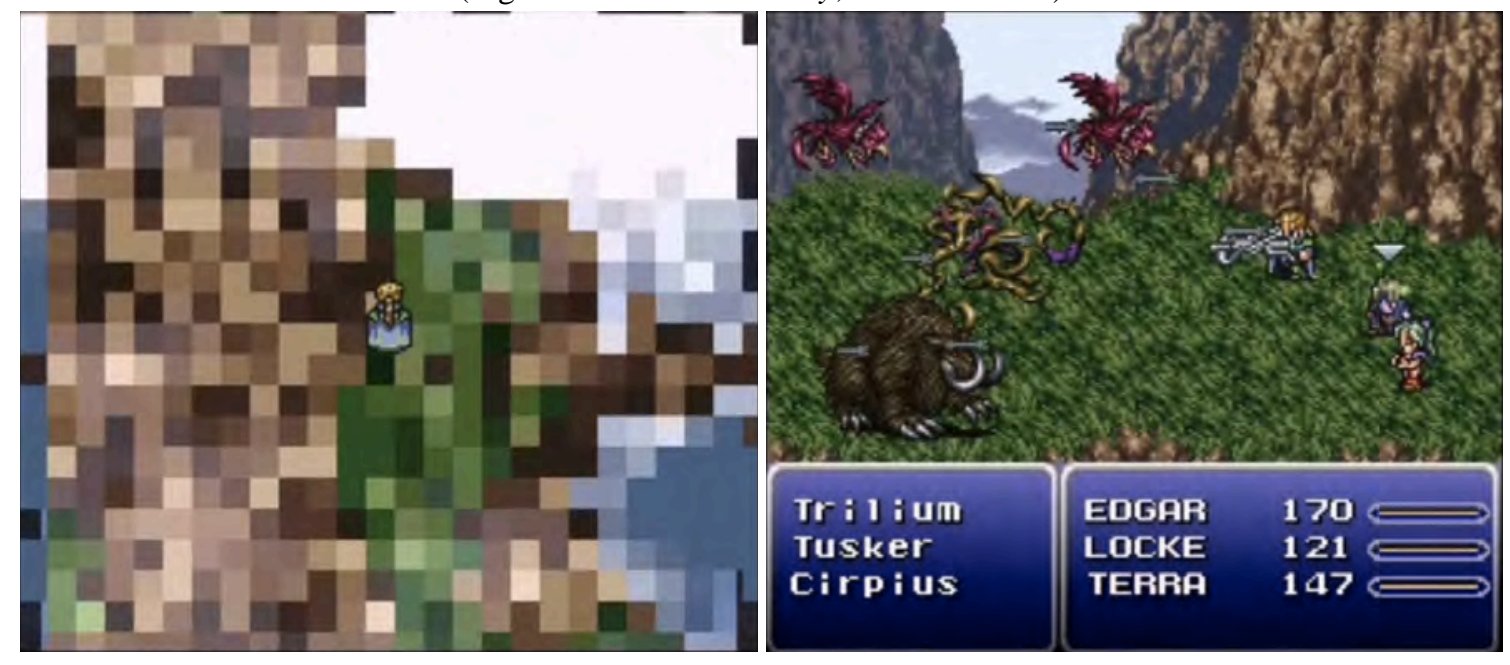

(Figuras 102 e 103: Final Fantasy VI, transição e tela de batalha)

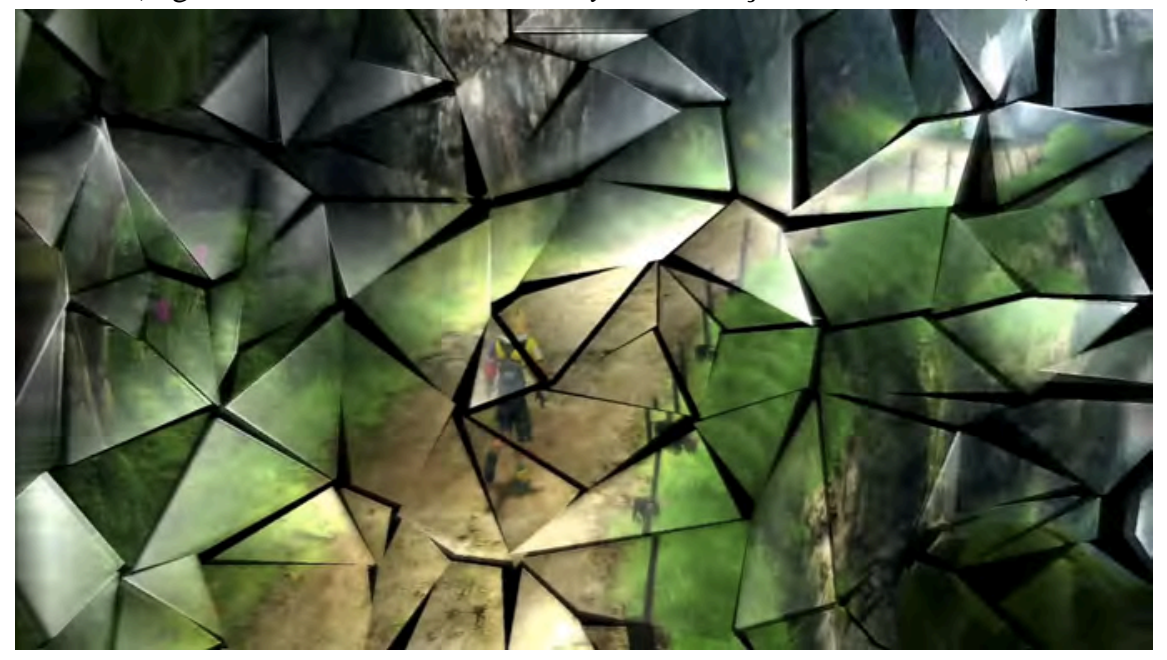

(Figura 104: Final Fantasy X, transição) 


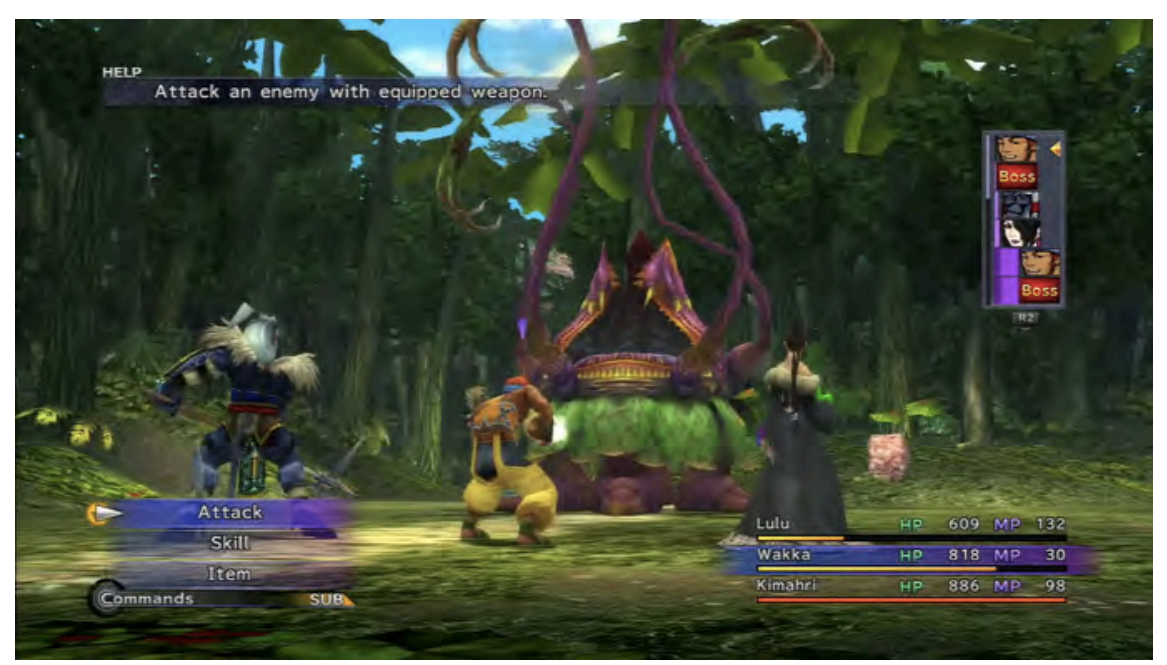

(Figura 105: Final Fantasy X, tela de batalha)

Apesar de graficamente diferentes, o sistema é basicamente o mesmo: cada personagem terá seu turno e executará a ação indicada pelo jogador, caso seus requisitos sejam atendidos (quantidade de energia mágica ou itens suficientes, por exemplo). A ordem em que personagens e inimigos realizam as ações é determinada por diversos fatores, como os atributos (velocidade, habilidades especiais) e a modalidade de combate (emboscada, cilada ${ }^{58}$ ); em Final Fantasy não há como visualizar de quem será o próximo turno, mas em Final Fantasy $X$ há um indicador na parte superior direita da tela, permitindo que se planeje melhor a batalha. Em Final Fantasy VI a ordem dos turnos não é fixa: há uma barra que é carregada para mostrar quanto tempo falta para o próximo turno, mas é possível aguardar e reordenar os comandos quando a barra de mais de uma personagem está cheia; isso permite que se interpolem turnos, inclusive os dos inimigos, em uma modalidade um pouco diferente de combate denominada Active Time Battle (ATB).

Final Fantasy XII apresenta um sistema um pouco diferente: não há transição para a tela de combate, pois os monstros e demais inimigos encontram-se na própria tela de exploração. As batalhas têm início assim que o jogador entra no campo de visão de um inimigo, o que permite que sejam evitadas - ou que vários inimigos sejam acumulados e combatidos ao mesmo tempo. Apesar dessa mudança, o desenvolvimento da luta ainda se dá por turnos, sendo necessário que cada personagem carregue sua barra de ATB antes de agir e selecione um alvo - não se trata, portanto, de controle direto das ações da

\footnotetext{
${ }^{58}$ Em encontros aleatórios, há chance de a batalha se iniciar com o título Preemptive Strike (traduzido no texto por "emboscada"), em que o grupo comandado pelo jogador ganha todos os turnos iniciais, ou com o título Ambush (traduzido no texto por "cilada"), em que ocorre o contrário. Em alguns títulos há outros modos além dos mencionados, mas eles não são recorrentes ao longo da série.
} 
personagem. Outro aspecto introduzido é a possibilidade de pré-programar ações, que serão ativadas quando as condições são atingidas e a barra de ATB está completa ("Usar Cure se a força vital de um aliado cair para menos de $70 \%$ do valor total", por exemplo) mesmo assim, a estrutura de turnos é mantida.

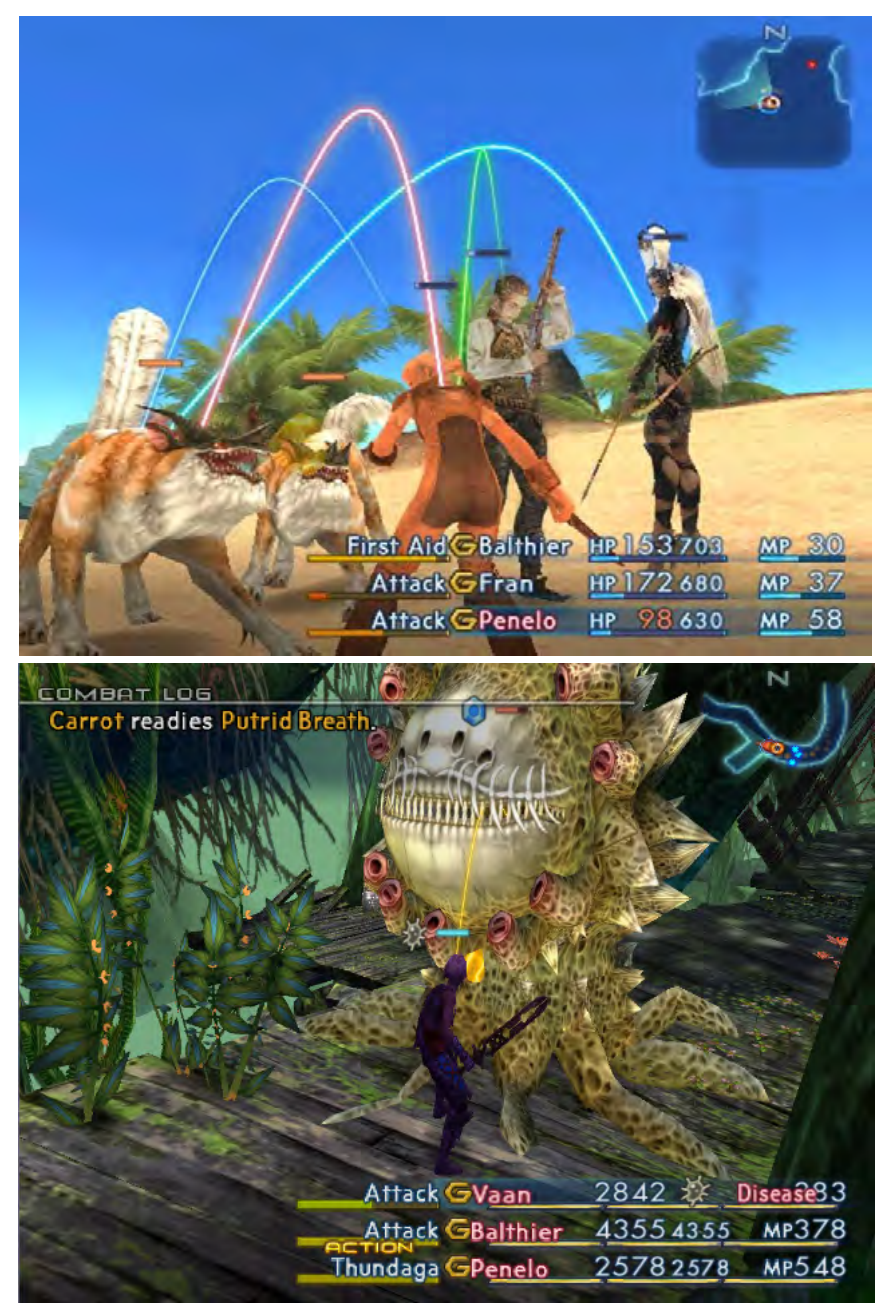

(Figuras 106 e 107: Final Fantasy XII, combates)

A gama ações disponível para cada personagem controlada pelo jogador também varia de acordo com critérios diversos. Dentre eles, há o sistemas de classes ou jobs, que indicam o papel que uma personagem tem no grupo - é nesse aspecto que a série Final Fantasy se afirma como RPG. Um White Mage (Mago Branco) vai ter disponíveis feitiços de cura e de combate a criaturas das trevas, enquanto um Thief (ladrão, gatuno) vai poder fazer uso de sua furtividade e até mesmo roubar itens dos inimigos. Em cada título, o sistema de classes muda, podendo ser fixo, em que cada personagem tem um papel específico (Final Fantasy IX, por exemplo), cambiável, no qual é possível trocar os jobs (como em Final Fantasy V), e contextual, em que o jogador pode fazer qualquer 
personagem aprender qualquer tipo de habilidade e administrar os papéis de acordo com suas preferências e o contexto (Final Fantasy XII, por exemplo).

A evolução das personagens pode ser acompanhada a partir de menus, nos quais o jogador tem opção de modificar o equipamento e organizar todos os recursos disponíveis, incluindo a formação do grupo (quando a quantidade de personagens disponíveis excede o limite máximo de posições na tela de batalha, que varia de três a cinco). As imagens abaixo (Figuras 108 a 110) mostram os menus de Final Fantasy e Final Fantasy X; na última delas (Figura 111) é possível ver um exemplo de sistema de evolução contextual mencionado acima, no qual o jogador escolhe as habilidades e atributos que vai adicionar a cada personagem, podendo criar um lutador com habilidades de cura e defesa, um mago resistente ou qualquer combinação que deseje:

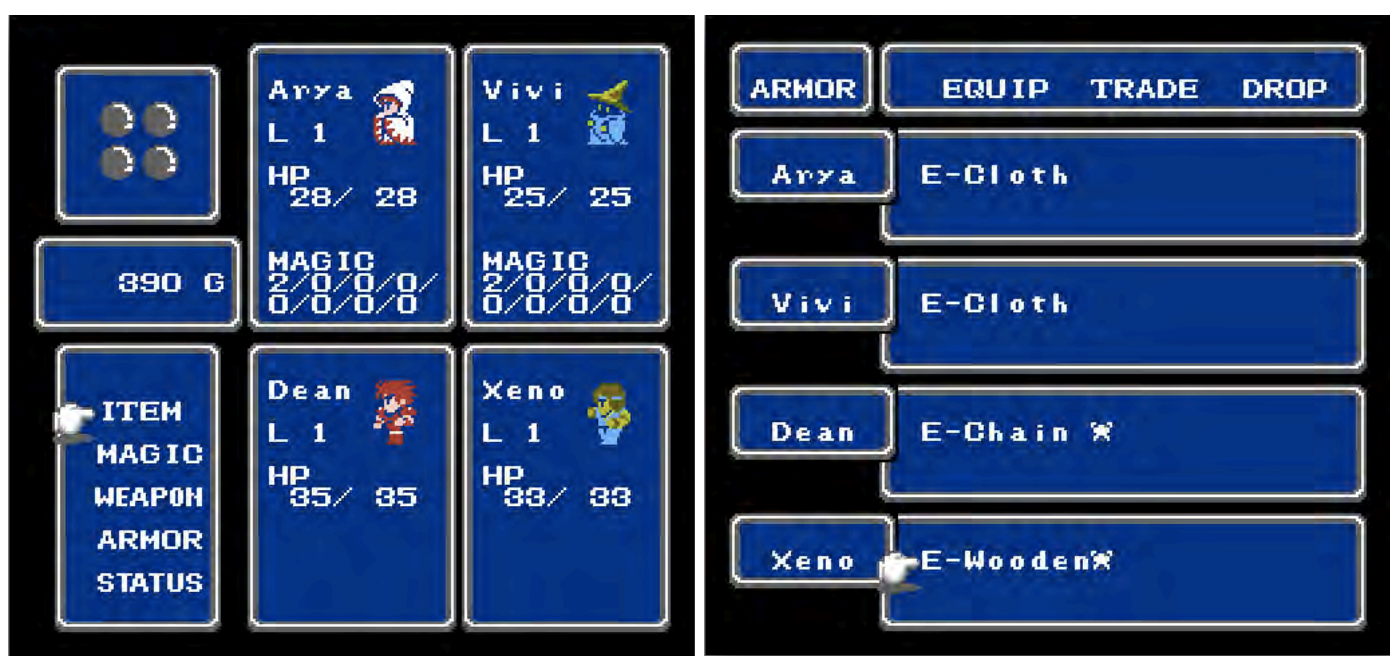

(Figuras 108 e 109: Final Fantasy, menu do jogador)

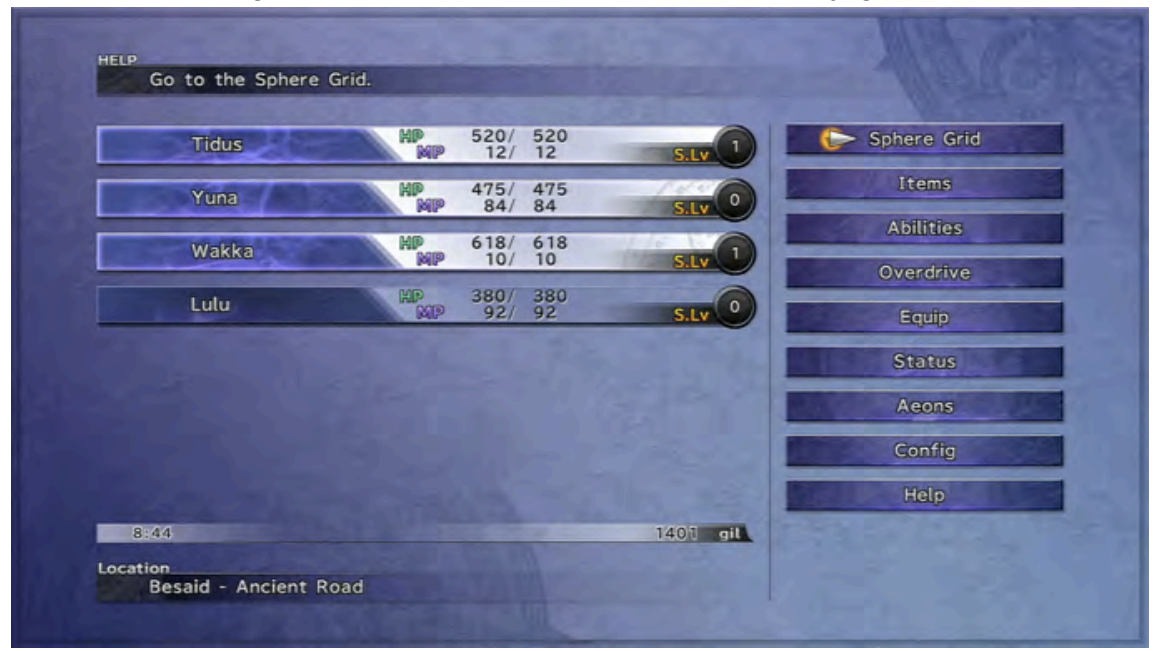

(Figura 110: Final Fantasy X, menu do jogador) 


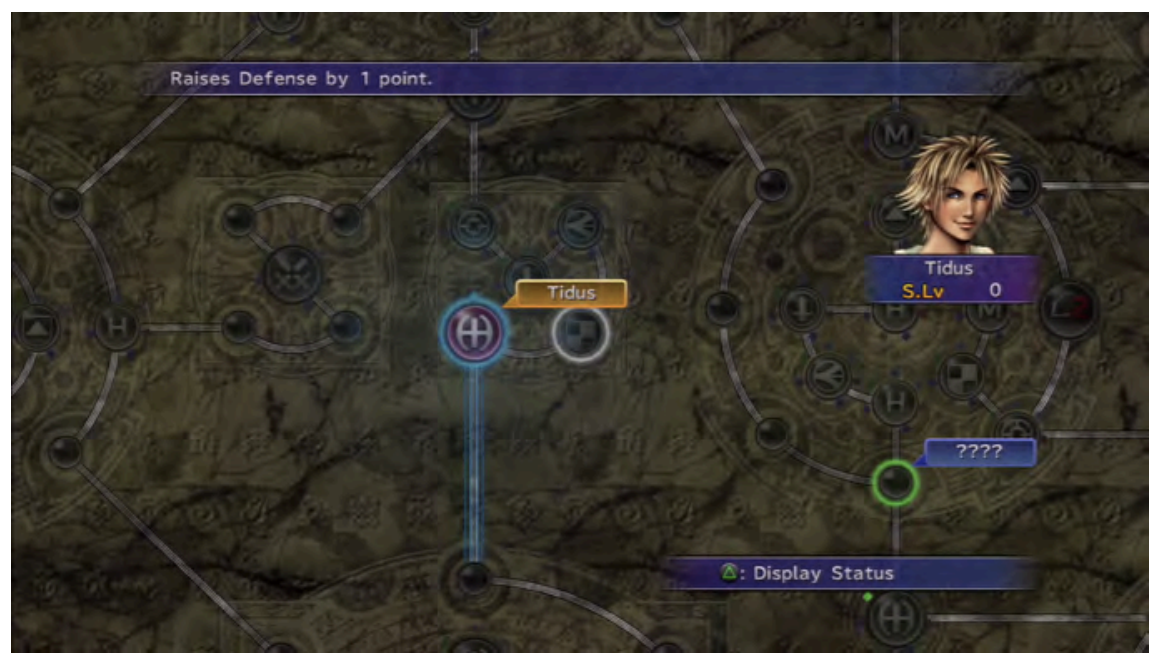

(Figura 111: Final Fantasy X, mapa de evolução de atributos e habilidades)

Apesar de haver mudanças entre os títulos - Limit Breaks, que são habilidades especiais muito poderosas e que dependem de diversas condições para serem usadas (a partir de Final Fantasy VI), mudança de posicionamento na batalha (mais avançado, garantindo maior poder de ataques físicos; recuado, garantindo maior defesa (existente em alguns títulos, como Final Fantasy IX)), substituições de equipamento e membros do grupo durante os combates (Final Fantasy X) - o sistema básico de cada título é essencialmente o mesmo: exploração por meio de acesso progressivo, marcado por mudanças no estado de jogo e liberdade na formação de grupo, gerenciamento de habilidades e itens. Final Fantasy XIII, no entanto, destoa da constituição de gênero, representando um tipo sui generis de RPG, que causa estranheza ao jogador já habituado a esse tipo de jogo. Faz-se necessário analisá-lo individualmente e apontar quais efeitos de sentido derivam dessa nova forma de estruturar um Final Fantasy e a que elas servem em relação ao conteúdo; como dito na Introdução desta dissertação, o Capítulo 4 será dedicado a essa análise. 


\section{Capítulo 4}

\section{Final Fantasy XIII e a estruturação da vingança como experiência}

Como dito anteriormente, este capítulo tem como objetivo a análise de um caso específico com base nos critérios teórico-metodológicos definidos nos capítulos anteriores; em linhas gerais, pretendemos aqui demonstrar como os procedimentos que dão forma ao jogo Final Fantasy XIII (Square-Enix, 2010) - ou seja, os elementos do plano de expressão - relacionam-se à estruturação de conteúdo da vingança, paixão que não pode ser devidamente explicada apenas pela análise do esqueleto narrativo e dos arranjos modais, mas requer um olhar mais abrangente que recobra desde o universo tensivo prévio a toda significação até as manifestações temáticas, figurativas e aspectuais do nível discursivo. Em suma, o desafio será verificar como o complexo passional do plano do conteúdo se manifesta no plano de expressão, agindo diretamente em sua forma, e demonstrar como a organização do sistema do jogo encontra-se "contaminada" pelo mesmo contínuo passional advindo da tensão original que gera a paixão e, assim, conduz a leitura do jogador para esse caminho. Nosso método será a exposição comentada de alguns pontos específicos da história de Final Fantasy XIII comparando-os com os atributos de jogo para formular, em linhas gerais, a experiência de enredo.

\subsection{Final Fantasy XIII: visão geral}

Lançado em 2009 no Japão e em 2010 no mercado ocidental, Final Fantasy XIII é o último título principal da série Final Fantasy a seguir a estrutura de um RPG de console brevemente descrita no Capítulo 3. Conta com duas sequências diretas, Final Fantasy XIII2 (2011, Japão/2012, mercado ocidental) e Lightning Returns: Final Fantasy XIII (2014) ${ }^{59}$, e é um dos títulos mais rentáveis da série.

\footnotetext{
${ }^{59}$ Apesar de apresentar sequências, a história contada em Final Fantasy XIII é completa em si mesma; Final Fantasy XIII-2 e Lightning Returns: Final Fantasy XIII tratam de eventos posteriores, sem uma conexão direta e necessária com o primeiro jogo, isto é, não há nada em Final Fantasy XIII que careça de desenvolvimento maior para fazer sentido.
} 
Apesar de receber retorno positivo por parte das revistas especializadas, a estrutura linear de Final Fantasy XIII, atípica em um RPG de console, gerou controvérsias, como demonstram os trechos a seguir retirados do artigo em inglês da Wikipedia:

\begin{abstract}
While critics generally praised Square Enix's attempt to revitalize the Final Fantasy series formula, many reacted negatively to the linear nature of the game, especially in the first ten chapters on Cocoon, an issue which many felt was compounded by the large reduction of towns, free-roaming capabilities, and interaction with non-player characters. GamePro described the gameplay as "a long hallway toward an orange target symbol on your mini-map that triggers a cutscene, a boss fight, or both," and 1UP.com criticized the linear aspect as the game's "biggest shortcoming", and felt the first section was "superficial." Edge and others awarded the game especially lower scores as a result of these aspects, with Edge in particular lowering the score they awarded the game to a five out of ten primarily due to the game's linear nature.

In contrast, reviewers from GamesRadar and Computer and Video Games appreciated the linear nature; the former stated that "the streamlined, focused structure eliminates potential tedium without dumbing anything down", while the latter felt it was "a clever move", and kept the player from being "[bogged] down with mundane number crunching, [and] finicky and repetitive leveling-up." Many negatively noted the gradual unfurling of the player's abilities over this first part of the game, from battle gameplay to selecting the party leader. Combined with the game's linear nature, some reviews went as far as to describe these chapters as "boring" until the world of Gran Pulse was revealed. Edge noted that while it did not do enough to make up for the opening chapters, at Gran Pulse the game "hits a sweet spot" as the narrative offers "hunting sidequests and the simple joy of exploring to see what visual marvel is around the next corner." ${ }^{60}$
\end{abstract}

A questão do divertimento não nos interessa neste trabalho, tendo em vista que ela é, como o próprio trecho aponta, relativa; nosso objetivo é verificar quais são os efeitos de sentido derivados da escolha dos desenvolvedores pela estrutura linear em detrimento de uma organização de acesso progressivo, relacionando plano de expressão e plano de conteúdo como fizemos brevemente com Resident Evil e Silent Hill. Para isso, examinaremos com maior vagar a estruturação de enredo de Final Fantasy XIII, apontando ao mesmo tempo a estrutura e os pontos da história que nos interessam aqui. $\mathrm{O}$ resumo completo do que conta Final Fantasy XIII (bem como o de todos os outros jogos digitais aqui analisados) e um glossário com os termos específicos (nomes de localidades, tipos de personagem) podem ser encontrados nos Anexos deste trabalho.

\footnotetext{
${ }^{60}$ http://en.wikipedia.org/wiki/Final_Fantasy_XIII (Acessado em 14/10/2014)
} 


\section{A estruturação de enredo na exploração}

Como de costume, uma cutscene tem início assim que o jogador escolhe a opção de iniciar o jogo. Após uma pequena fala de uma narradora, que se coloca também como personagem, um trem cheio de pessoas aprisionadas aparece:

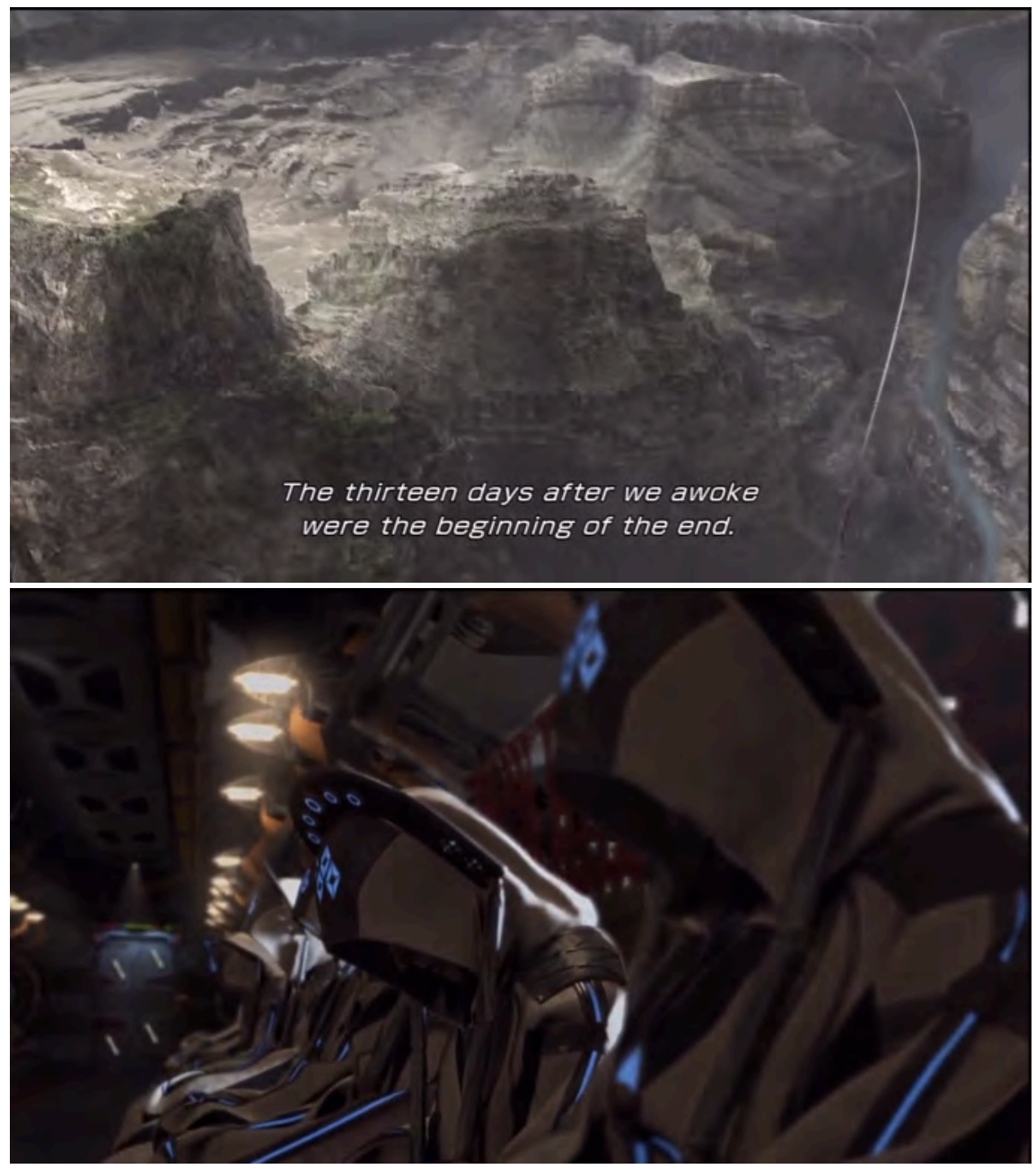

(Figuras 112 e 113: cutscene inicial ${ }^{61}$ )

O jogador nada sabe sobre o trem ou sobre as pessoas que ali estão; como em outros jogos do gênero, as informações a respeito do universo ficcional e dos objetivos que movem cada personagem são fornecidas aos poucos, em concomitância com a exploração. Após o final da cutscene, em que vemos uma personagem identificada na legenda como "Lightning" pedir a outra, identificada como "Sazh", para que fique quieta enquanto ela arquiteta a fuga, o jogador assumirá o controle durante uma batalha:

\footnotetext{
${ }^{61}$ Todas as figuras do Capítulo 4 correspondem a Final Fantasy XIII.
} 


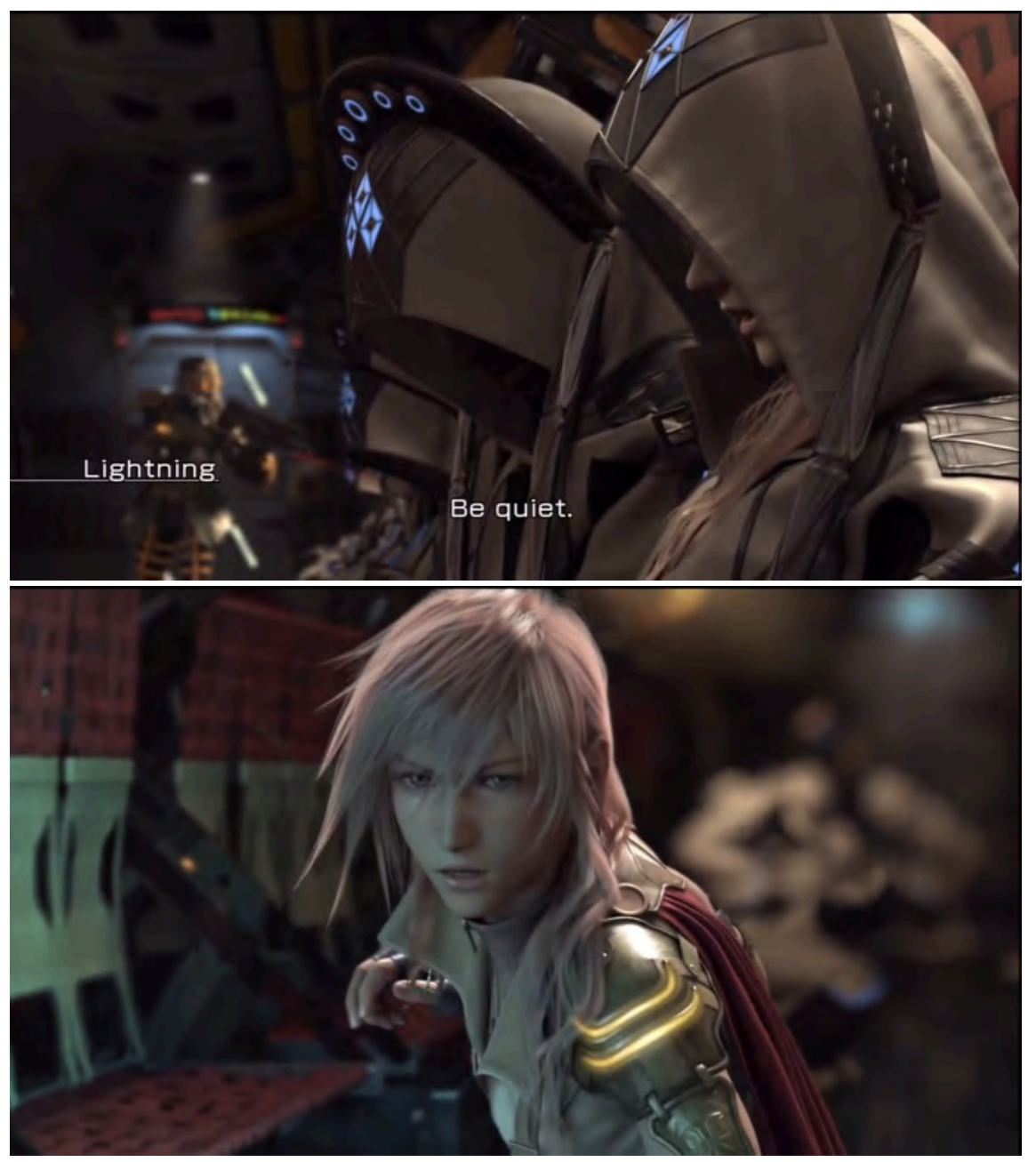

(Figuras 114 e 115: cutscene inicial, momento em que Lightining se liberta)

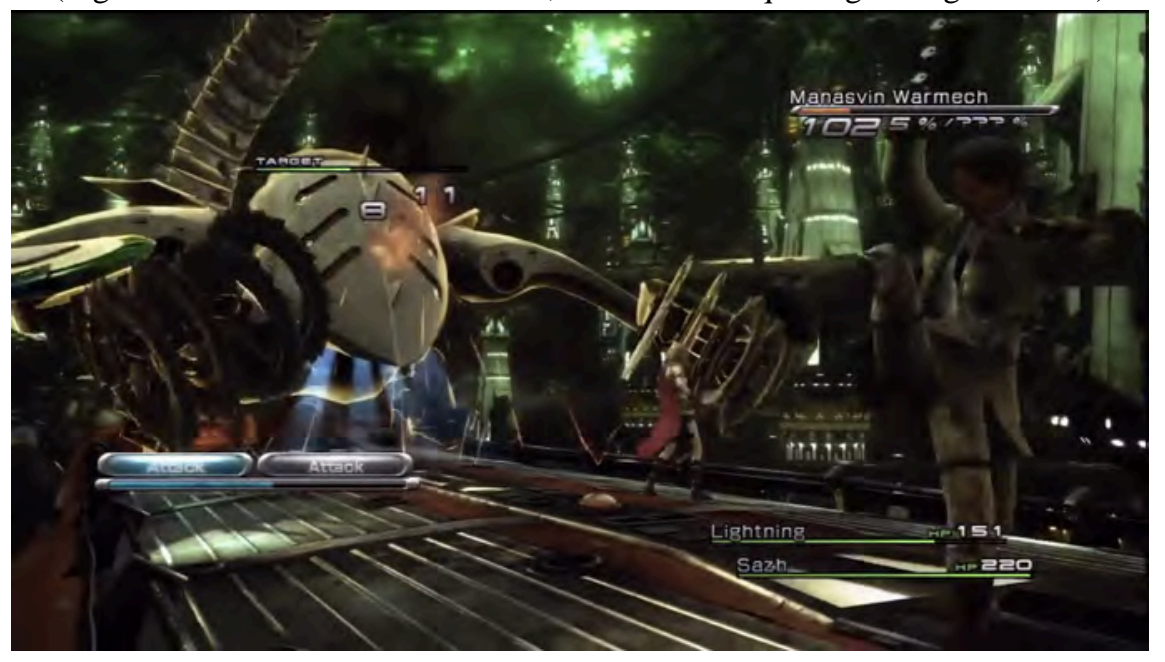




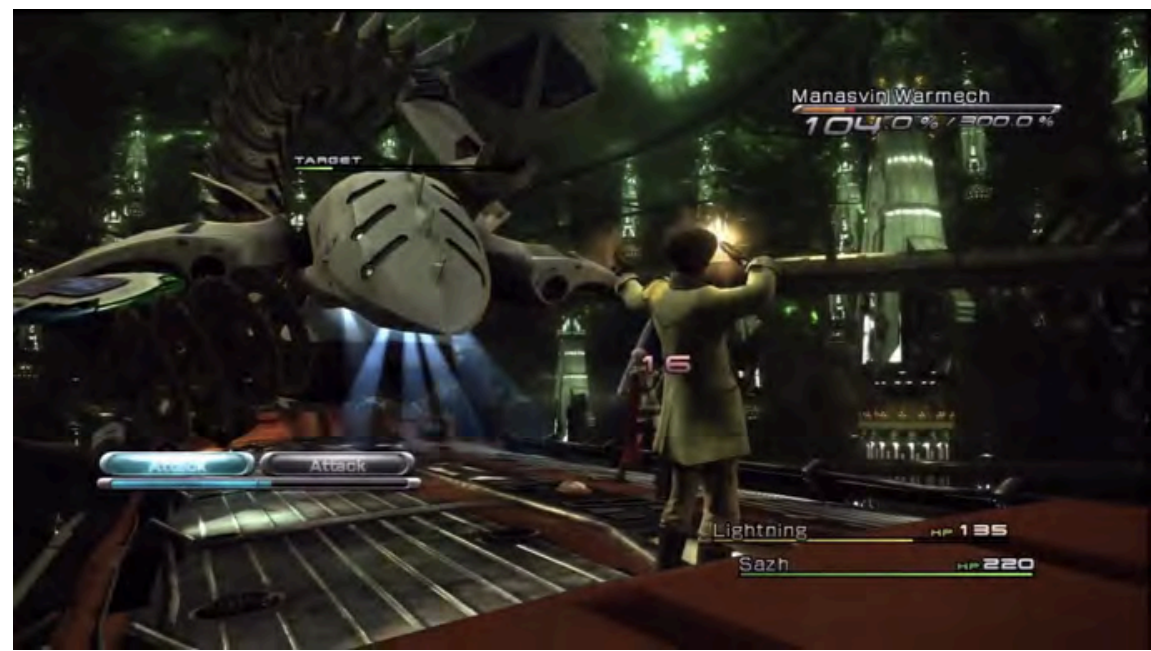

(Figuras 116 e 117: primeira batalha, sendo Lightning a personagem efetivamente controlada)

O sistema de turnos foi mantido e, no geral, a batalha é mais semelhante a jogos como Final Fantasy VII e VIII que a Final Fantasy XII, em que, como visto anteriormente, não havia transição para a tela de combate. No entanto, existe uma diferença enorme entre o sistema de turnos tradicional e o de Final Fantasy XIII: não há possibilidade de controlar (ou programar previamente em detalhes) a ação de todos os membros do grupo; com a exceção do líder (Lightning, no caso das imagens acima), todas as outras personagens vão selecionar seus comandos de acordo com o desenvolvimento da batalha e o papel escolhido para elas em combate (veremos mais informações sobre isso mais adiante).

Durante o combate, se o HP (medidor de energia vital) do líder cair para zero, a partida se encerra e a tela de Game Over aparece com a possibilidade de um Retry que reinicia o jogo alguns momentos antes do combate ter início, para que o jogador possa modificar algumas opções (as quais explicaremos em maior detalhe mais adiante). De qualquer maneira, o controle do fluxo de combate é extremamente complexo e bem mais restritivo que nos jogos anteriores.

Vencendo o combate, a exploração tem início na primeira área do jogo:

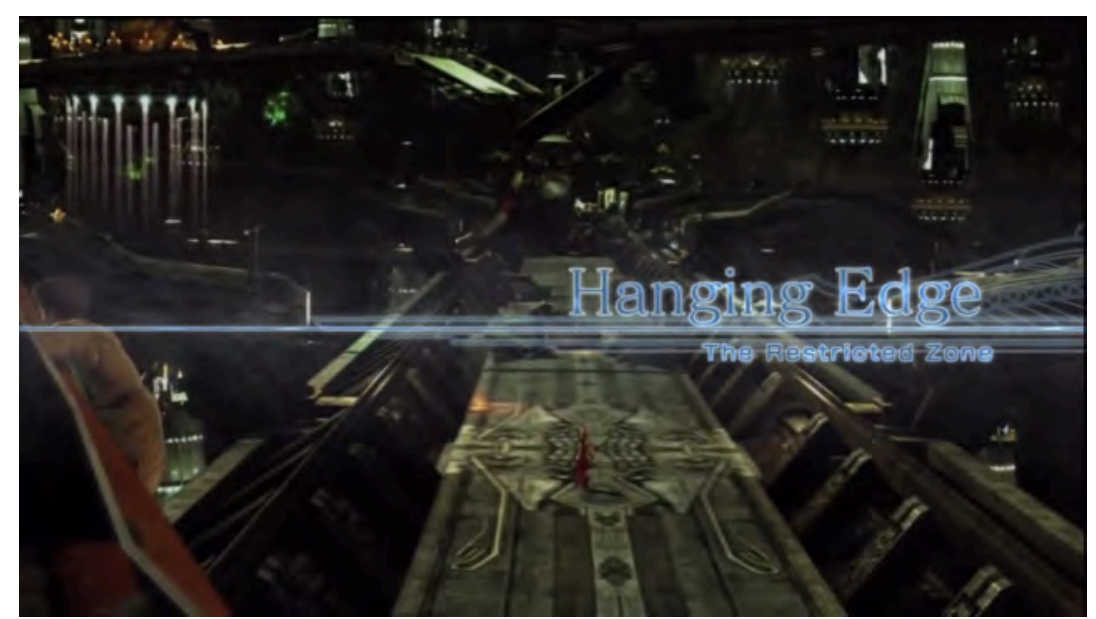



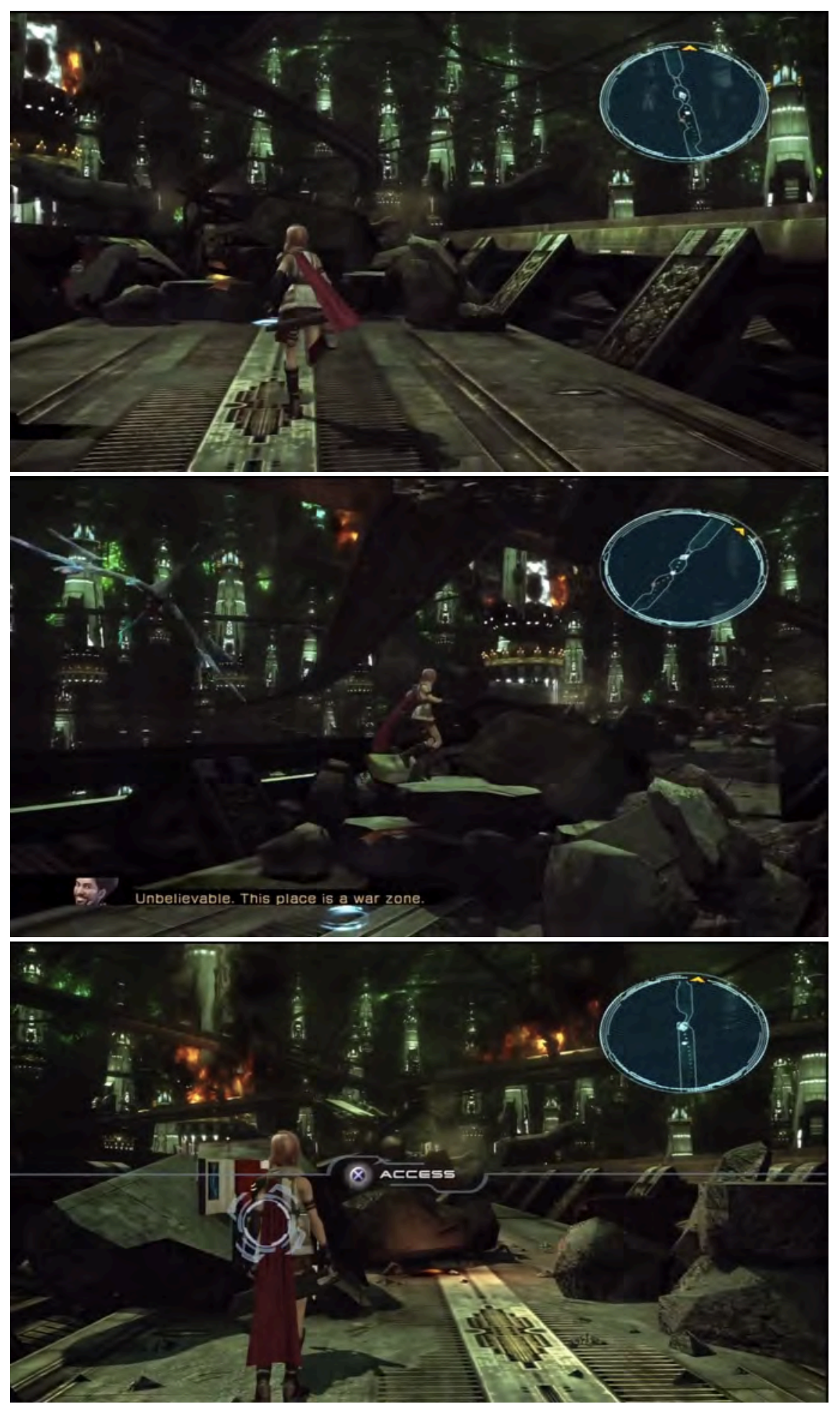

(Figuras 118 a 121: primeiro área do jogo, explorada por meio do controle de Lightning)

Como pode ser observado no minimapa no canto superior direito das imagens, o cenário a explorar é praticamente um corredor com alguns pequenos e poucos desvios que levam a áreas sem saída; é praticamente impossível deixar passar qualquer item que esteja disponível, pois seguir em frente garante que se acesse tudo o que o cenário tem a oferecer. 
Outro aspecto que contribui para a linearidade é o fato de não haver encontros aleatórios: tendo em vista que todos os inimigos disponíveis aparecem na tela e não retornam após os combates terem sido finalizados (a não ser que se vá para outra área e volte), há um número fixo de batalhas e todos os jogadores irão passar por elas praticamente da mesma forma - é possível usar itens para ficar invisível temporareamente e escapar dos inimigos. Esse aspecto incentiva o jogador a seguir em frente e a não se demorar em área alguma:

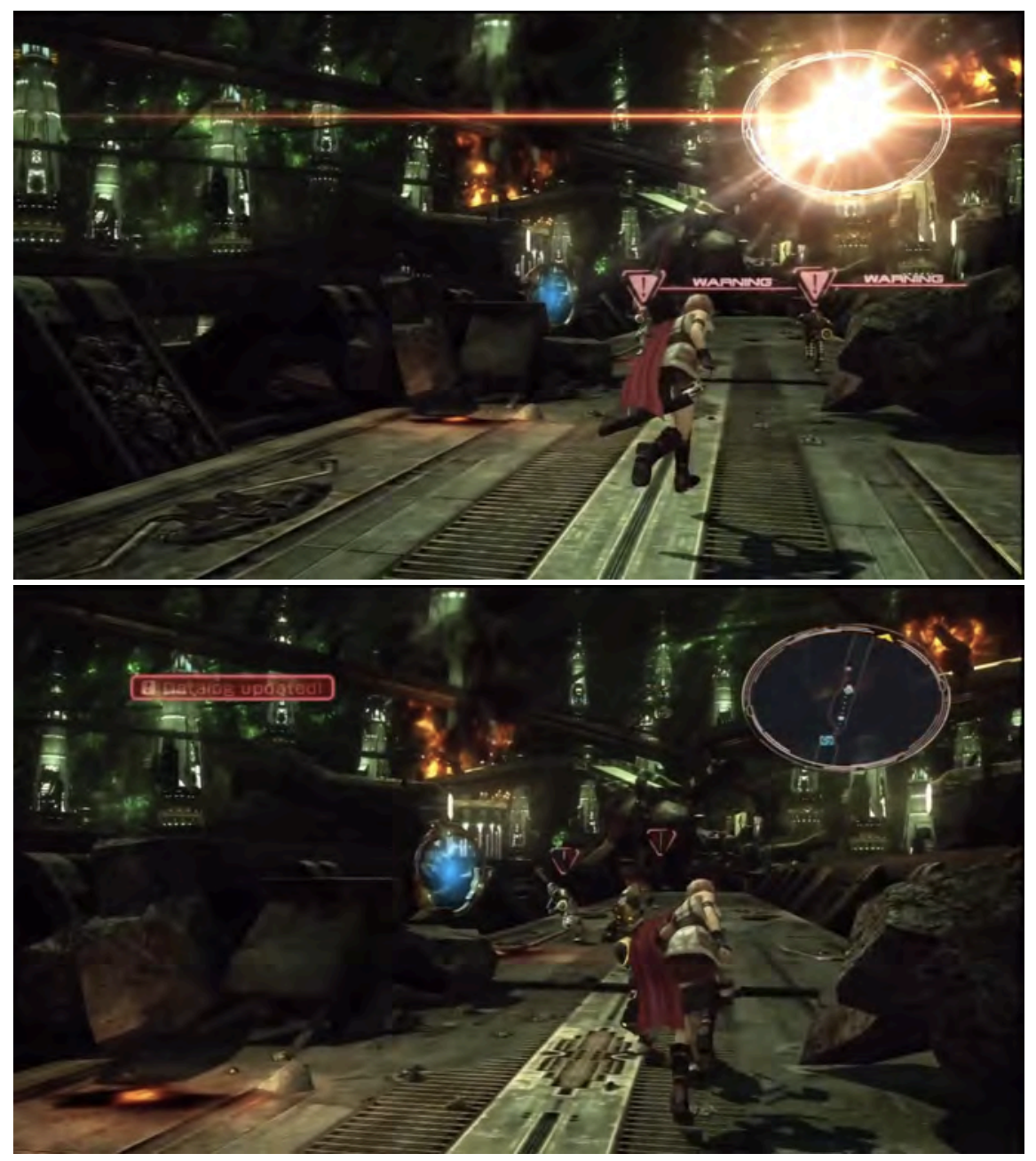

(Figuras 122 e 123: exemplo de encontro com inimigos)

A descrição apresentada no texto do Wikipedia é bastante pertinente: trata-se de seguir o mapa e enfrentar os inimigos disponíveis para assistir a cutscenes e mudar o estado de jogo. 

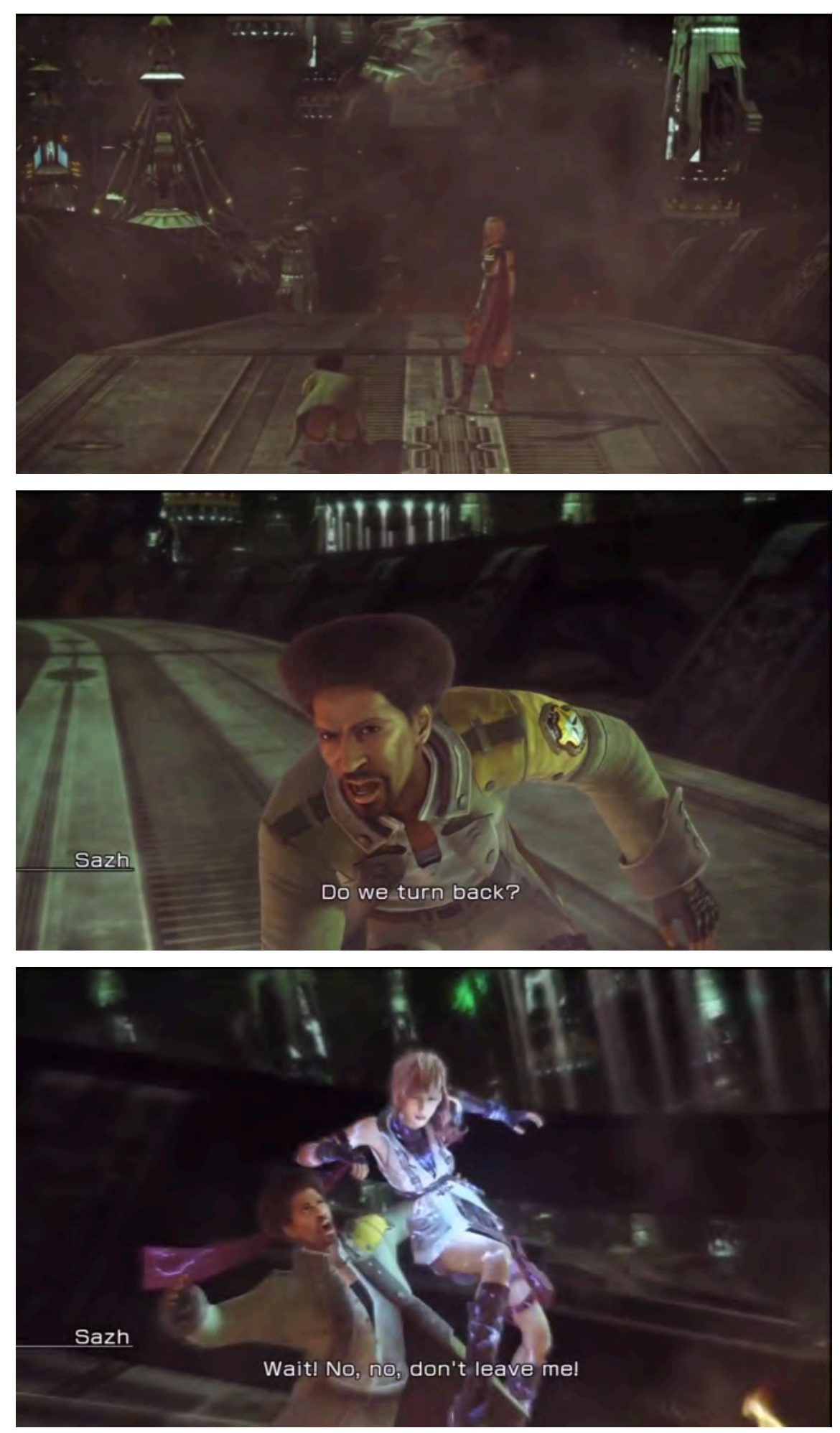

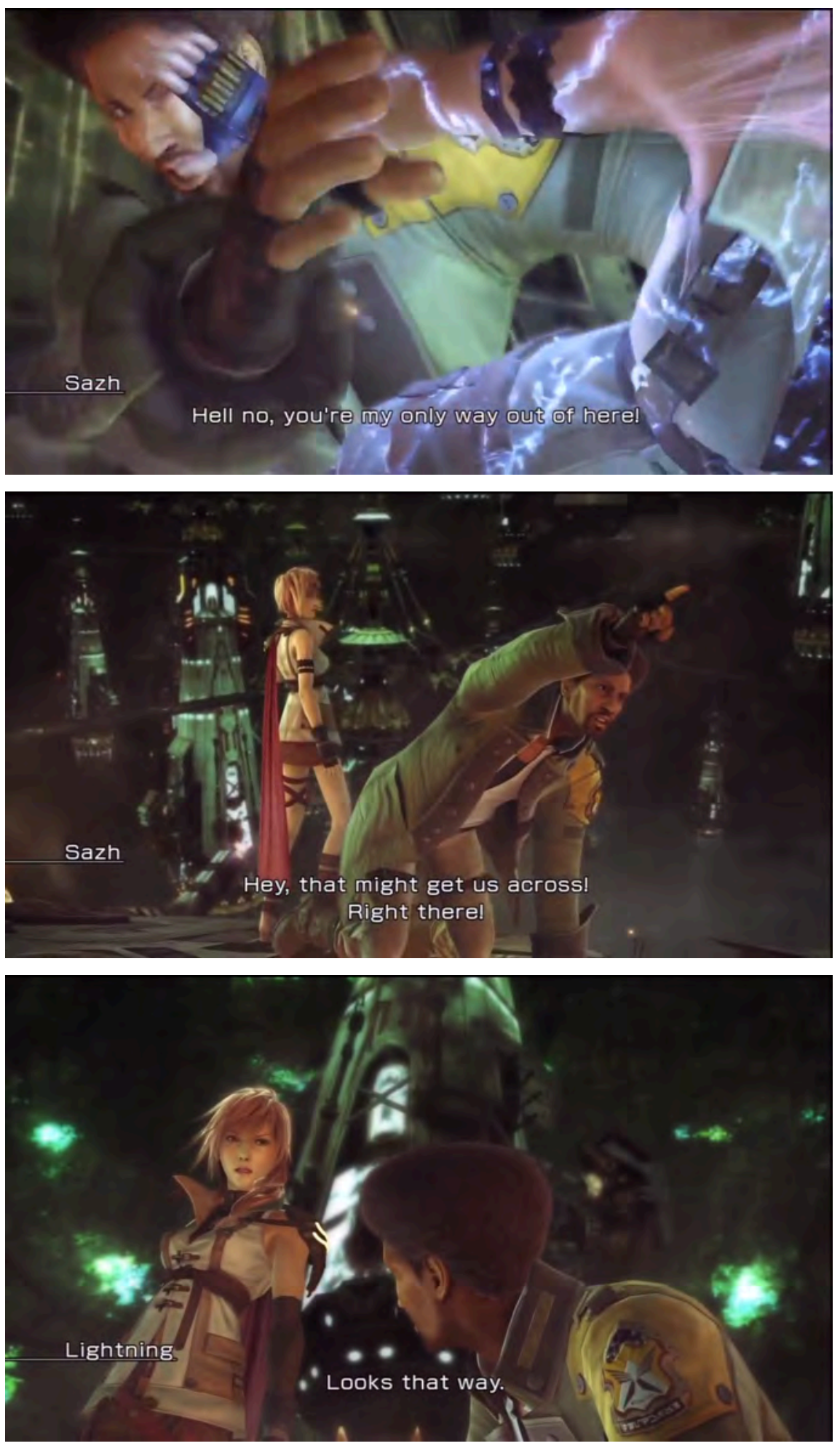

(Figuras 124 a 129: cutscene que marca uma mudança de estado de jogo na primeira área)

A cada mudança, o jogador descobre mais coisas a respeito da história e passa a jogar em outras áreas e, algumas vezes, com novas personagens. Diferentemente de outros jogos da série, não é possível voltar para os cenários visitados previamente depois que uma mudança de estado de jogo ocorre. 


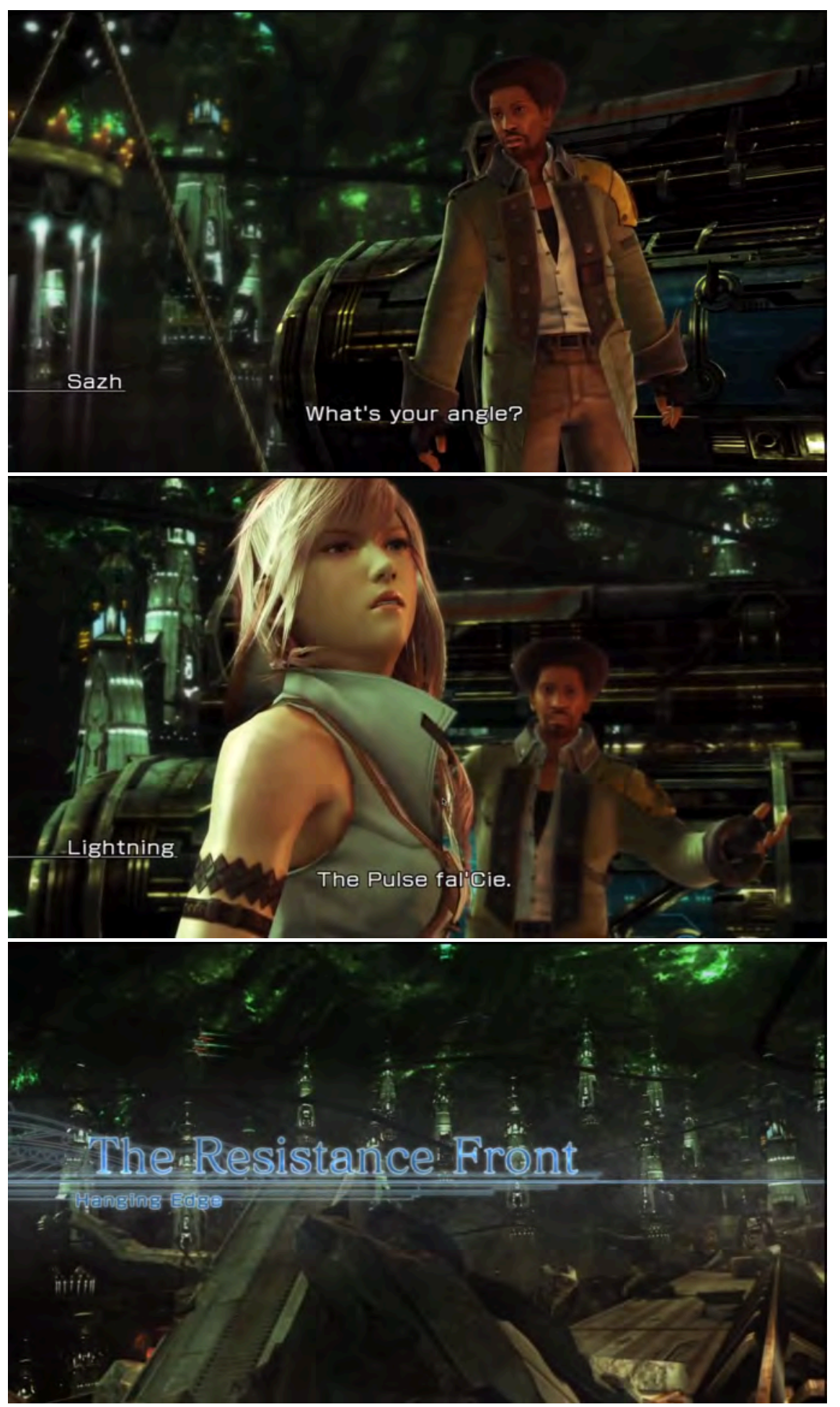

(Figuras 130 a 132: cutscene que marca uma mudança de estado de jogo e de controle de personagem) 


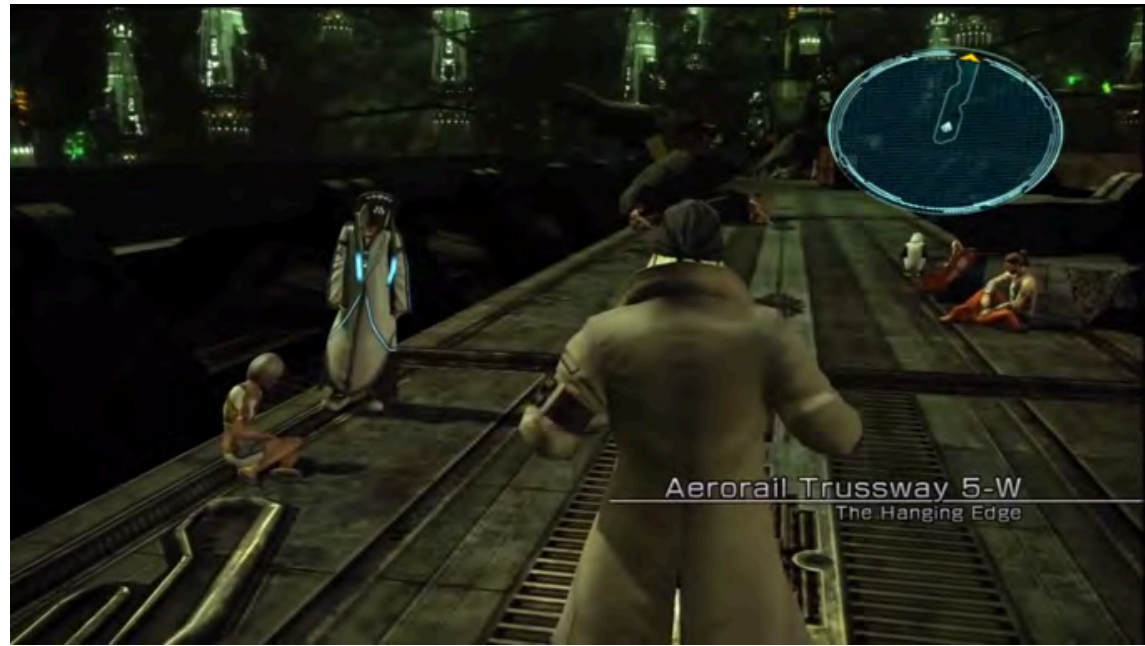

(Figura 133: o jogador assume o controle de Snow após assistir à cutscene)

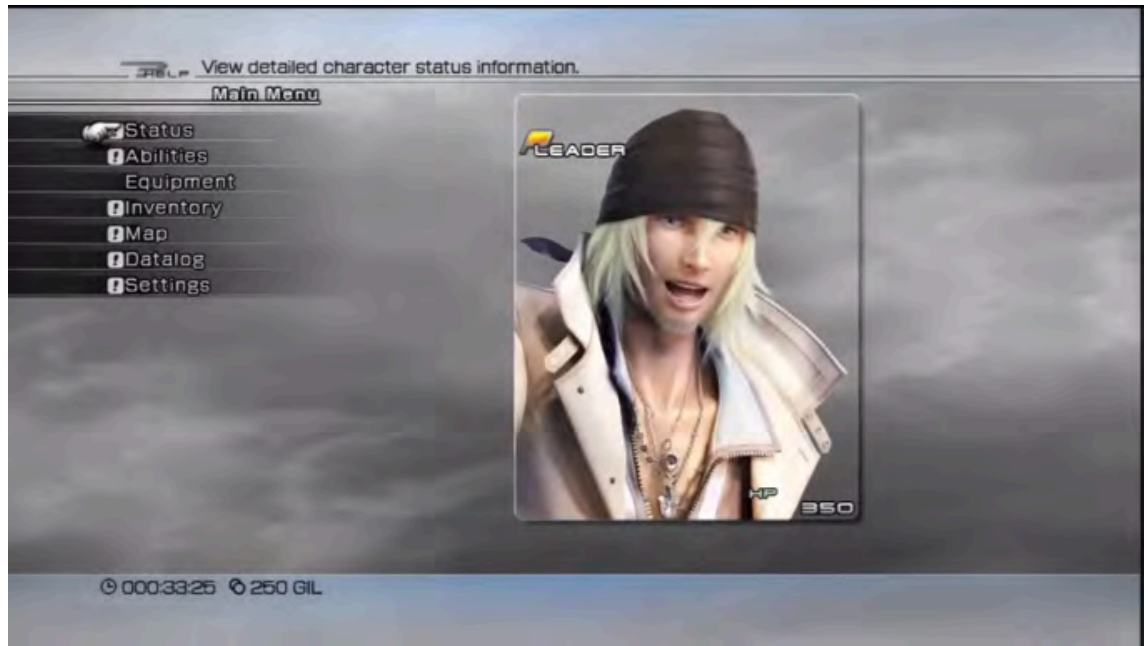

(Figura 134: menu do jogador logo após Snow tornar-se a personagem efetivamente controlada)

O menu que pode ser visto na imagem acima é característico de RPGs e apresenta as entradas básicas que permitem visualizar a lista de habilidades, o equipamento etc. $\mathrm{O}$ Datalog é particularmente interessante, pois ele contém informações sobre aspectos variados do jogo, desde detalhes a respeito dos pontos fracos e fortes dos inimigos até resumos da história do jogo e biografias das personagens, histórico das instituições:

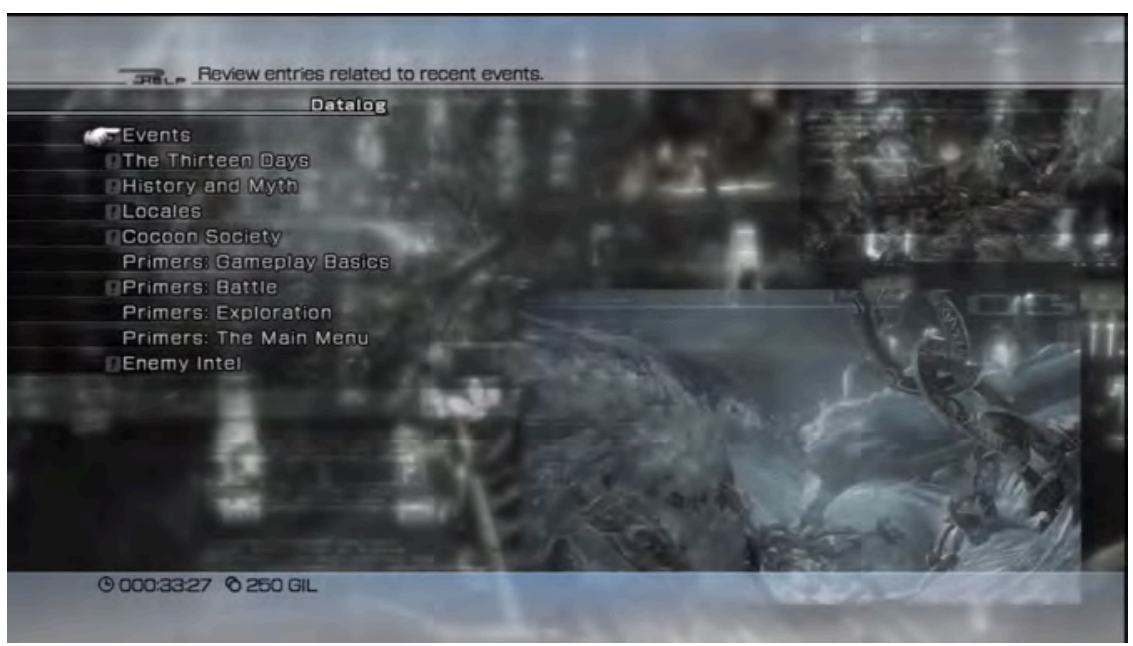




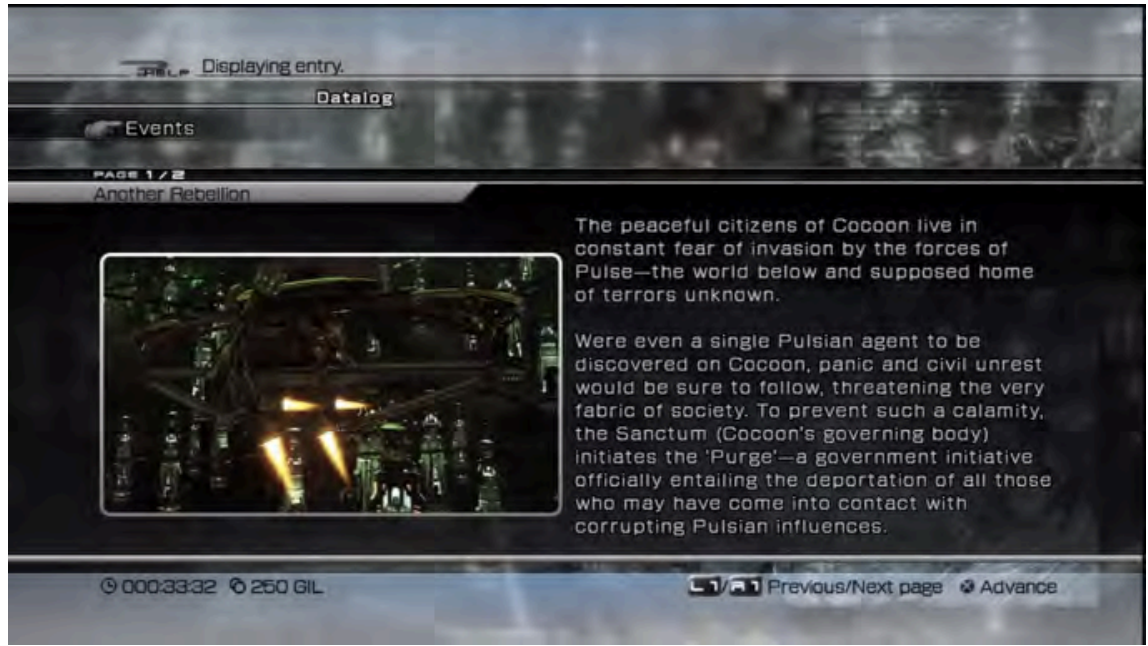

(Figuras 135 e 136: o Datalog, uma das principais fontes de informação sobre os elementos do jogo) A atualização dos dados é feita automaticamente quando o jogo muda de estado ou depois que algumas side quests são realizadas (as linhas opcionais de enredo serão discutidas também mais adiante).

A estrutura de enredo e de jogabilidade é basicamente esta por quase $70 \%$ do jogo (capítulos 1 a 10), e em nossa leitura ela está pareada com os desenvolvimentos de plano de conteúdo: as personagens são consideradas inimigas do Estado e devem agir sorrateiramente, às margens da sociedade para realizar seus objetivos, seja de fuga, de resolução dos problemas ou de vingança contra os responsáveis pela situação em que se encontram. Como dito ao longo desta Dissertação, nosso foco será o trabalho com a vingança e por isso nos deteremos nos momentos em que o grupo contém as personagens Lightining e Hope.

\subsection{As condições da vingança}

Iniciemos nosso estudo de caso definindo melhor o que entendemos aqui por vingança. Da versão digital do dicionário Houaiss (2009) consta o seguinte para esse verbete:

n substantivo feminino ato ou efeito de vingar(-se)

1. ato lesivo, praticado em nome próprio ou alheio, por alguém que foi real ou presumidamente ofendido ou lesado, em represália contra aquele que é ou seria o causador desse dano; desforra, vindita

2. qualquer coisa que castiga; castigo, pena, punição Ex.: seria esta doença uma $v$. por suas crueldades 
A primeira acepção pode ser analisada, em um primeiro momento, nos termos base do percurso gerativo do sentido como demonstra Greimas (1983) ao situar a vingança como algo relacionado à cólera ${ }^{62}$. No caso descrito por ele, o sujeito crê se ver privado por parte de outro sujeito de algum objeto de valor com o qual mantinha uma relação de conjunção ou, pelo menos, de uma possível conjunção - trata-se da frustração de um sentimento de espera, que pode ser tanto simples (i.e., compor-se como objeto mesmo) quanto fiduciária, originária de "une relation quasi contractuelle - qui se trouve de ce fait rompue - avec un autre sujet” (p. 227). Como dito, essa relação contratual é originária de um crer por parte do sujeito $\mathrm{A}$ em um fazer do sujeito $\mathrm{B}$, uma relação de confiança desse sujeito, que, no caso, é frustrada: o sujeito B não age da forma como deveria, aos olhos de A.

Esse contrato, segundo Greimas, não precisa ser explícito ou conhecido por parte do segundo sujeito, que fica como "devedor" sem nunca ter estabelecido um acordo de fato: a relação se dá por meio de simulacros, "ces objets imaginaires que le sujet projette hors de lui et qui, bien que n'ayant aucun fondement intersubjectif, déterminent néanmoins, de manière efficace, le comportement intersubjectif en tant que tel" (Ibidem, p. 230). A frustração dá origem a uma crise de confiança do sujeito que se vê atingido tanto pela falta de ação do outro quanto pelo fato de haver depositado sua esperança em uma projeção. Essa decepção une-se à insatisfação, que acarreta uma atitude de reprovação violenta, encolerizada, que pode tomar a forma de uma vingança, caso haja ofensa (real ou imaginada).

A ofensa, para Greimas, tem como base uma ação do outro, que passa a se configurar como um anti-sujeito, na medida em que deliberadamente age para privar o sujeito de seu objeto de valor. Um ponto importante a salientar é que, para Greimas, a ofensa não reside na ação do outro, mas também em um simulacro:

\footnotetext{
Car l'offense a beau être une "blessure", l'offenseur ne "blesse" effectivement l'offensé que si celui-ci "se blesse" lui-même, en reproduissant, sur un autre plan, sa "blessure". Une gifle, par exemple, est évidemment la manifestation somatique de l'offense, mais, malgré la douleur qu'elle peut causer, ele n'est certainement pas la "blessure" dont nous parlons: la suprême élégance dans ce domaine consiste à esquisser une gifle - et non à la donner - en effleurant le visage avec un gant afin de ne laisser subsister que le seul message qu'elle est censée transmettre. Il s'agit, en effet, de bien autre chose: d'une "blessure morale", d'un "honneur blessé". (Ibidem, pp. 238-239)
}

\footnotetext{
${ }^{62}$ Aristóteles (2005), de modo similar, relaciona a vingança à ira (pp. 161-6).
} 
Vamos, agora, tentar "aplicar" esse modelo de análise em Final Fantasy XIII. No caso de Lightning e de Hope, as perdas da irmã e da mãe, respectivamente, representam evidentemente a ofensa, o objeto de valor que é retirado de alguma forma por um antisujeito. O problema reside, justamente, na determinação de qual figura (ou figuras) será associada a esse papel actancial. No caso de Lightining, sua irmã, Serah, lhe é tirada pela ação do Fal'Cie Anima, vindo de Pulse, que a marca como sua L'Cie - espécie de humano superpoderoso e que deve obedecer qualquer ordem dada por ele - para que a garota realize seus intentos; quanto a Hope, sua mãe, Nora, é morta pelas tropas militarizadas de Cocoon enquanto tentava salvar Snow, noivo de Serah e líder de uma frente de resistência. No entanto, os alvos da vingança das personagens não são as figuras mais óbvias: Lightning decide derrubar Eden, o Fal'Cie responsável por Cocoon como um todo, e consequentemente toda a estrutura política; Hope, por sua vez, direciona seu percurso para o assassinato de Snow, que recrutara sua mãe para lutar contra as tropas de Cocoon.

Embora seja perfeitamente possível que um mesmo papel actancial seja representado por diversas figuras (diversos atores) e, no enredo, correspondam a diversas personagens - como bem demonstra a obra literária $O$ Conde de Monte Cristo, de Dumas , isso não parece suficiente para explicar o processo de "transferência de alvo" efetuado por Lightning e Hope. Em suma, tratamento meramente sintáxico-semântico da paixão vingança nos diversos níveis do percurso gerativo do sentido não abarca toda a sua complexidade.

Como foi apontado no Capítulo 2, há mais aspectos envolvidos na produção de sentido: a disposição do sujeito, seu horizonte tensivo e sua relação com o próprio corpo, os quais, como vimos a partir de Greimas e Fontanille (1991), permeiam todos os níveis do percurso gerativo do sentido, imprimindo o "perfume passional" ao discurso como um todo. Passemos, então, a analisar a vingança sob diversos pontos de vista para determinar qual o modo de existência semiótico de um sujeito vingativo, quais suas disposições corporais e o horizonte tensivo que dão origem às manifestações complexas dessa paixão.

\section{A vingança como crise identitária}

Comecemos pela reflexão de Giddens (2002, p. 47): "todos os indivíduos desenvolvem um referencial de segurança ontológica de alguma espécie, baseado em vários tipos de rotina" e "ser ontologicamente seguro é ter, no nível do inconsciente e da 
consciência prática, 'respostas' para questões existenciais fundamentais que toda vida humana de certa maneira coloca". O indivíduo sente-se ontologicamente seguro por meio de um conjunto de referências exteriores, mas que é, de certa maneira, interiorizado por ele e o ajuda a lidar com as diversas questões existenciais que a vida propõe a todo momento. De acordo com Giddens, é preciso que o sujeito possa considerar tais questões como respondidas, de modo a seguir em frente com a construção de sua narrativa.

Outro ponto salientado por Giddens é a confiança, desenvolvida na infância:

\begin{abstract}
A confiança que a criança, em circunstâncias normais, investe nos que cuidam dela [...] pode ser vista como uma espécie de inoculação emocional contra ansiedades existenciais - uma proteção contra ameaças e perigos futuros que permite que o indivíduo mantenha a esperança e a coragem diante de quaisquer circunstâncias debilitantes que venha a encontrar mais tarde. A confiança básica é um dispositivo de triagem em relação a riscos e perigos que cercam a ação e a interação. (p. 43)
\end{abstract}

O "casulo protetor" ao qual a confiança básica dá suporte é uma das defesas do indivíduo contra possíveis ataques a sua integridade identitária derivados da sua relação com os outros. Em suma, é necessário haver uma relação de confiança entre o eu e os outros que o cercam para possibilitar a inserção do sujeito num ambiente em que os quadros de referência exteriores possam ser relacionados à autobiografia derivada da reflexão que o sujeito-no-mundo faz sobre si mesmo - é preciso haver confiança para que haja mobilidade identitária.

Essa reflexão é particularmente interessante no caso da vingança e, mais especificamente, de Final Fantasy XIII, na medida em que a ideia de quebra de contrato é central. Lightning, que trabalhava para uma das instituições militares de Cocoon, vê na decisão de expurgo da população tomada pelo governo a materialização dessa quebra de confiança básica: sua irmã Serah transformou-se em uma estátua de cristal e agora ela própria foi marcada como L'Cie, sendo perseguida como inimiga do lugar que sempre lutou para proteger. Hope, por sua vez, considera Snow responsável pela morte de sua mãe na medida em que a promessa de proteção feita por ele não foi cumprida; o garoto, agora sem a figura materna e sem perspectiva de viver em sociedade por causa da marca de L'Cie que está em seu braço - sendo a boa vida que o garoto tinha em Cocoon a única possibilidade de existência aceitável -, usa a vingança como combustível assim como Lightning o faz. 
É interessante apontar também a questão da marca de L'Cie, que indica uma relação "escravocrata" entre as personagens e o Fal'Cie que as marcou: caso não cumpram os seus desígnios, sofrerão uma pena pior que a morte; Lightning e Hope perdem aquilo que é de mais básico na constituição identitária: a disposição de seu corpo. Segundo Giddens, “o controle rotineiro do corpo é crucial para a manutenção do casulo protetor do indivíduo em situações de interação cotidiana" (p. 58). A angústia gerada pela quebra abrupta e definitiva da segurança ontológica faz com que a única forma possível de seguir em frente seja a estereotipia inerente à paixão.

Essa visão própria do corpo evidentemente se relaciona com as reflexões de Fontanille (2011) que mencionamos no Capítulo 2. Podemos complexificá-la ainda mais se trouxermos a filosofia do reconhecimento de Ricoeur (2006), que é bastante importante para a semiótica do corpo de Fontanille - a divisão do corpo em moi, soi-ipse e soi-idem feita por Fontanille (2011) é, inclusive, feita a partir de Ricoeur.

A reflexão a respeito daquilo que Ricoeur (2006) chama de "homem capaz" é fruto de um percurso reflexivo sobre o vocábulo reconhecimento tal como usado ao longo da história da filosofia - o objetivo do autor é elaborar uma teoria do reconhecimento autônoma em relação à(s) teoria(s) do conhecimento. O percurso apresentado passa por três modos básicos de uso do vocábulo, começando pela sinonímia entre reconhecimento e identificação, passando pelo modo reflexivo até chegar no reconhecimento mútuo. No centro desse percurso, aparece a figura do homem capaz, definido na segunda parte do estudo (pp. 85-160) como aquele que pode dizer, fazer, narrar(-se) e assumir para si os prejuízos decorrentes de seus atos (imputabilidade). O homem capaz reconhece-se em seus atos na medida em que se coloca como fonte desse ato, como sua causa, e por isso pode ser responsabilizado - assumir as consequências de algo implica em atestar que pode realizar esse algo. Cada elemento citado acima responde por uma faceta do homem capaz, facetas que, em nosso ponto de vista, não podem ser entendidas separadamente, mas como diversos pontos de um continuum.

No caso do poder dizer (pp. 109-111), Ricoeur traz como argumento a pragmática de Austin, que coloca os atos ilocutários como uma das modalidades de fazer: dizer é fazer algo com palavras. Nessa chave de leitura, essa capacidade de afirmar como um poder tem relação forte com o poder fazer de fato, posto que a ação com as palavras tem, nos dias atuais, um impacto tão grande quanto as ações "de fato" - vide casos de bullying e agressão verbal online. Se pensamos o poder fazer (pp. 111-114) em termos semióticos, 
entramos na questão da competência necessária à performance, que, além de representar um ponto teórico, tem um aspecto interessante se pensado de acordo com a lógica do fazer como afirmação da capacidade de fazer, fazer porque se pode fazer - e, da mesma maneira, dizer por poder dizer. A questão do poder narrar(-se) (pp. 114-118) envolve a identidade como narrativa, em relação forte (e explicitamente citada) com a semiótica greimasiana, numa noção de progressão ab quo e ad quem - que será melhor definida em reflexão posterior sobre a memória e a promessa -, cujos polos interrelacionados Ricoeur denomina de idem e ipse. A imputabilidade (pp. 119-122), que pode ser resumida em um poder ser responsabilizado, relaciona-se com a identidade narrativa na medida em que pressupõe o sujeito como fonte que assume para si a autoria de algo (e que se lembra de haver feito) - e fazer algo parece indicar uma promessa de tomar responsabilidade futura.

Memória e promessa (pp. 123-145) aparecem como capacidades especiais nesse quadro, pois dizem respeito a aspectos chave da questão identitária entendida como narrativa: as origens $a b$ quo e o projeto $a d$ quem, que Ricoeur relaciona (mas não restringe) respectivamente aos polos idem e ipse. A memória tem relação forte com a constância, a identificação de traços que permitem o reconhecimento (aqui bastante aproximado da acepção "identificação" que Ricoeur estuda em profundidade na primeira parte de seu livro) do sujeito como o mesmo de antes. Trata-se do aspecto que se mantém ao longo do tempo, como um sinal impresso. É interessante ressaltar a discussão em torno da imaginação apresentada nesse ponto por Ricoeur, a qual podemos facilmente relacionar à produção de ficção: a memória é produzida pelo sujeito não só no aspecto ativo da rememoração, mas na própria arbitrariedade dos traços reconhecidos, que o são sempre para um sujeito - a memória nasce da percepção dos traços de identidade lidos por um sujeito. No polo oposto, a promessa aparece como projeção de um eu que deve manter-se fiel ao prometido. Analisando morfologicamente os vocábulos prometer e projetar, verificamos a presença do prefixo de origem latina pro em ambos, indicando um movimento para a frente que, em termos temporais, corresponde ao futuro; os verbos mittere e iacere, responsáveis pela raiz dos vocábulos significam, respectivamente, enviar/colocar e lançar: prometer é colocar no futuro e projetar é lançar para o futuro. Em ambos, a noção de deslocamento temporal é evidente: o eu de agora lança-se para o futuro, indicando uma constância de traços que poderão ser identificados. Em outras palavras, o eu de agora coloca-se numa relação de memória com o eu do futuro muito parecida com a relação que se tem com o eu do passado, dizendo "daqui a algum tempo, será possível 
olhar para trás e reconhecer meu estágio atual como parte de meu estágio futuro" - o eufuturo lembrará do eu-atual, assim como este se lembra do eu-passado.

Outro aspecto importante ressaltado por Ricoeur é a promessa geral que está por trás de cada promessa singular, a de manter a palavra dada a outem, apontando para o aspecto da alteridade presente na identidade narrativa. Quando se quebra uma promessa singular, a promessa geral também é quebrada, e não só para os sujeitos envolvidos diretamente, mas para a sociedade como um todo, marcando o sujeito como não confiável, desonesto - Dante reserva um círculo do inferno inteiro para aqueles que traem a confiança entre os homens. Giddens (2002) fala da espécie de acordo tácito existente entre membros de uma sociedade, em que há a promessa mútua de não agressão, dialogando com Ricoeur no aspecto de alteridade inerente ao ato de prometer e no reconhecimento mútuo implícito ali: é preciso que o outro seja reconhecido como tal para haver alteridade.

Voltando a Final Fantasy XIII, podemos pensar a problemática das personagens nos seguintes termos: a falta inexorável do ente querido retirado abruptamente mexe com a estrutura complexa de formação do sujeito na medida em que o polo da alteridade desaparece - irmãos são assim definidos em relação uns aos outros e um filho o é apenas em relação a uma mãe. Toda a projeção subjetiva desaparece nesse contexto, assim como a memória: o sujeito não se reconhece como o mesmo de antes e não sabe como se imaginar futuramente. O não reconhecimento de Lightning e Hope como membros da comunidade por causa da falta de domínio do próprio corpo se soma a isso e torna ainda mais complexo o quadro.

Pensando de acordo com a semiótica francesa, todas essas questões alteram não só o modo como o sujeito percebe seu próprio corpo, mas também sua maneira de perceber o mundo ao seu redor. A vingança entra como substituição dessa linha de coerência essencial para que o sujeito funcione como tal, uma espécie de competência necessária para que qualquer performance seja efetuada - em última instância, para que se possa viver -, e, ao fim e ao cabo, representa uma chave de leitura do mundo, uma grade perceptiva por meio da qual todos os dados e textos serão lidos.

Constatar isso, no entanto, não é suficiente para nosso estudo. É preciso captar o modo como essa modificação de percepção se dá na superfície dos textos e se reflete no plano de expressão - em outras palavras, precisamos captar seu parecer. Para captar as nuances específicas de Final Fantasy XIII, serão feitas comparações com alguns textos 
tradicionais da cultura ocidental - as três tragédias que compõem a Oresteia, de Ésquilo, e O Conde de Monte Cristo, de Dumas.

\section{A vingança em Ésquilo}

É senso comum entre os estudiosos da literatura clássica que a trilogia pode ser lida em um contínuo, e, nessa chave, percebemos uma série de imbricações complexas que constroem uma temática, uma figurativização e um andamento bastante peculiar associado à vingança. No Agamêmnon vemos o chefe dos aqueus ser assassinado por sua esposa Clitemnestra, após retornar da guerra de Troia. O motivo é o fato de Agamêmnon haver sacrificado sua filha Ifigênia anos antes para que houvesse bons ventos para os barcos dos gregos partirem rumo a Troia. Remoendo por vários anos a amargura da mãe privada da filha, Clitemnestra vê em Agamêmnon um antagonista e planeja junto a Egisto, seu amante, um ardil para assassinar o marido. Em As Coéforas há a consequência da vingança de Clitemnestra: seu filho, Orestes, volta do exílio para vingar a morte do pai num plano arquitetado junto a Electra, a qual encontra chorando junto ao túmulo de Agamêmnon. Disfarçando-se de viajante estrangeiro, Orestes consegue entrar oculto no palácio e assassinar Egisto e Clitemnestra, tornando-se alvo das Fúrias Vingadoras por seu matricídio. As Eumênides falam do julgamento de Orestes e do apaziguamento das Fúrias colocando fim ao ciclo de vinganças que acompanha a Casa de Atreu.

Os contratos fiduciários entre Agamêmnon e Clitemnestra, e entre ela e Orestes encontram-se bastante claros, bem como os simulacros que circulam entre os sujeitos (a imagem do bom marido, da boa esposa, e do bom filho) e que são sucessivamente quebrados. O motivo da vingança do ente querido é duplicado e problematizado: para vingar a filha, mata-se o marido; para vingar o pai, comete-se um matricídio. Essa figurativização da relação de parentesco é geradora de uma tensão particular bastante recorrente na vingança: o aumento da intensidade com que se percebe o fazer do outro é evidenciado pela relação afetiva existente entre os sujeitos; a tonicidade é sempre elevada na vingança.

A questão moral é relativizada nas peças: apesar de motivada por uma ação vil do anti-sujeito, o que poderia justificar a reação, o vingador age sempre às escondidas, por meio de ardis. A vingança nunca é direta, colocada às claras nem sancionada por uma instituição superior. Quem detém o poder não se vinga, pois domina também as 
instituições e pode, portanto, agir sob o nome da justiça. A vingança é atributo dos exilados, dos proscritos, daqueles que caminham à margem, como Clitemnestra, Orestes e as Fúrias, as quais são obrigadas a recuar diante da autoridade de Atena - o sujeito é colocado fora do centro por algo maior que ele e passa a perceber o outro por esse viés. Além disso, o andamento dado à vingança é lento, característico de um olhar afeito ao escrutínio, ao ruminar: prepara-se lentamente o ardil, a ira é sempre alvo do recrudescimento que, inversamente, diminui o andamento próprio da intensidade.

Essa configuração torna bastante complexo o quadro tensivo da vingança, pois o andamento lento é aliado a um alto grau de tonicidade, restringindo e ampliando ao mesmo tempo a percepção do eixo espaço-temporal: tudo é visto e programado para compor a vingança, o que subordina totalmente a o inteligível ao sensível - o mundo se torna extensão do sujeito e mero instrumento para seu intento quando qualquer figura é, no nível narrativo, relacionada a percursos de uso dominados pelo percurso de base previamente delineado. Ao mesmo tempo, o escrutínio caracteriza-se como ampliação da percepção extensa do espaço-tempo, relativizando a minimização do inteligível pelo sensível sugerida pelo aumento da tonicidade.

Finalizando nossa apreciação da Oresteia, cabe ressaltar que, se parte da base moral e ética da vingança, tais quais as conhecemos no mundo ocidental, encontram-se bastante fundamentadas nas tragédias de Ésquilo, o desenvolvimento de enredo canônico e os dilemas morais que conhecemos atualmente ainda não estavam totalmente presentes: Clitemnestra não se questiona a respeito do direito que tem de vingar-se, muito menos Orestes; eles simplesmente agem obstinadamente em busca da finalização do programa de base constitutivo da vingança. Além disso, há uma mistura entre o que entendemos por vingança e a noção de justiça, que, para nós, difere de modo bastante sutil. Para compreender a diferença, passemos à análise de $O$ Conde de Monte Cristo, onde a complexidade apontada acima aparece de modo bastante claro.

\section{Dumas e o paradigma ocidental de vingança}

Na obra de Dumas vemos a saga de Edmond Dantès em sua busca por vingança contra aqueles que arrancaram sua liberdade e sua noiva (Mercedes) e permitiram que seu pai morresse de fome enquanto ele se encontrava trancafiado nas masmorras do Castelo de If por um crime que não cometera. Para levar a cabo seu intento, Dantès elabora um plano 
complexo que envolve um maquinário extensivo de disfarces, ardis, intrigas e outros artifícios para jogar seus inimigos uns contra os outros, os quais representam os mais ilustres membros da sociedade parisiense.

O estabelecimento das pré-condições para a vingança encontra-se na primeira parte do romance: Dantès, modesto marinheiro, noivo de Mercedes e filho de um pobre senhor habitante de Marselha, é vítima da inveja de dois homens, Danglars (colega de trabalho, um dos oficiais do navio em que Dantès trabalhara) e Fernand (primo de Mercedes), que, com a conivência de Caderousse (vizinho de Dantès), acusam-no de ser conspirador bonapartista em uma época em que isso constituía crime grave. Levado a interrogatório no dia de seu noivado, é enganado por Villefort (o vice-procurador do rei), que ao perceber que Dantès, apesar de inocente, estava sendo usado como portador de uma carta endereçada a seu pai (o sr. Noirtier de Villefort), cujo conteúdo contribuiria para uma conspiração bonapartista, dá ordens de levar Dantès ao Castelo de If para que seja trancafiado sem um processo. Preso por catorze anos e instruído nas mais diversas ciências pelo Abade Faria, seu companheiro de cárcere, Dantès finalmente consegue escapar com um segredo: a localização de um tesouro de soma exorbitante escondido na Ilha de Monte Cristo. Ao dirigir-se para lá, Dantès encontra os meios de equilibrar os pratos da balança e, assumindo as identidades de Simbad, o Marujo, de Abade Busoni e de Lorde Willmore, volta a Marselha e arredores para averiguar o que ocorrera durante seu cárcere. Descobrindo Danglars feito barão e banqueiro riquíssimo, Fernand ostentando o título de Conde de Morcerf e casado com Mercedes, e Villefort ocupando a posição de Procurador do Rei em Paris, Dantès, após recompensar os poucos amigos que haviam sido bondosos para com seu velho pai, traça seu plano de vingança ${ }^{63}$.

Os simulacros e as ofensas podem ser vistos claramente no texto: o juiz que deveria ser imparcial e julgar de acordo com a lei, supostamente igual para todos, mente e aprisiona Edmond para o próprio benefício; Danglars, por pura inveja, quer prejudicá-lo no progresso em sua carreira na marinha mercante; e Fernand cobiça sua noiva e por isso deseja vê-lo preso. A traição daquilo que se considera o pacto "natural" de não agressão entre os homens, bem como a quebra de uma promessa feita por Villefort, representam as ofensas geradoras do rompimento do contrato social. Além disso, há a complexificação

\footnotetext{
${ }^{63}$ Não se fará uma análise do nível narrativo, correlacionando cada ator figurativizado a um actante para demonstrar qual a estrutura. Tal análise foge do escopo deste trabalho, pois, dada a extensão da obra, careceria de um estudo totalmente dirigido para esta finalidade. Faremos apenas alguns apontamentos relevantes para a análise proposta sem o intuito de esgotar a obra em si.
} 
evidente de algumas relações interpessoais: o primo da noiva, quase um parente; o magistrado, que deveria se ocupar da defesa dos mais fracos; e, por fim, o coleguismo esperado na vida da marinha mercante - todos esses fatores aumentam a tonicidade inerente à vingança e, assim, modificam a percepção do sujeito, como apontado anteriormente. A partir disso, os simulacros de bons companheiros, homens de bem, justos, todos desaparecem, cedendo lugar à instauração dos papéis de anti-sujeito: são percursos que inevitavelmente concorrem com o do sujeito-Dantès. As relações são, a partir de então, polêmicas, não mais entre sujeitos e adjuvantes, mas entre antagonistas.

Encerrada a preparação e iniciada a busca pela vingança, Dantès desaparece em definitivo do romance dando lugar ao Abade Busoni, a Lorde Willmore e ao Conde de Monte Cristo, máscaras utilizadas nas aparições sociais para travar relações, que, no entanto, não se constituem como intersubjetivas. Agindo nas sombras, nenhuma personagem representa ali um sujeito capaz de estabelecer uma relação de alteridade rompidos os contratos iniciais, não há mais fidúcia e os simulacros não despertam qualquer tipo de confiança. Danglars é um objeto na vingança de Dantès contra Morcerf, assim como a esposa daquele constitui-se como peça chave na derrocada de Villefort. Os diversos percursos de uso confundem-se em nome de um único percurso de base: a liquidação de uma falta fiduciária acarretada pela perda de confiança inicial.

$\mathrm{Na}$ estruturação de enredo, os jogos de luz e sombra são projetados nas escolhas do narrador, que abandona o foco do Conde e passa a focar nos objetos - que não deixam de se considerar sujeitos - que caminham pouco a pouco para a própria destruição. O leitor observa sem conhecer os planos, sabendo apenas que os acasos são controlados por alguma mão invisível ligada ao Conde, ser aparentemente onisciente, onipresente e onipotente no romance - de vítima contingencial, o Conde passa a mestre, dominando o acaso. No entanto, isso sempre se dá em meios às sombras, fora dos limites das instituições oficiais controladas pelos inimigos de Dantès. Edmond atua como um jogador de xadrez, movendo as peças em um tabuleiro e influenciando o movimento de todas as outras, com a única ressalva de que as peças não sabem que são peças e o jogo só lhes é apresentado em sua conclusão: o Conde remove todas as máscaras e expõe os ardis no último segundo a Morcerf e Villefort, levando aquele ao suicídio e este à loucura com a revelação de que os golpes da Providência haviam sido, na realidade, arquitetados por um agente humano.

Essa relação entre humano e divino perpassa todo o romance: Dantès se vê como agente da Providência, detentor do direito de premiar e punir, acima dos homens. No 
entanto, a recusa em matar Albert no duelo, a pedido de Mercedes - única que o reconhece sob o disfarce do Conde - impõe uma relação de alteridade onde havia apenas relações puramente objetais. Do mesmo modo, a morte do pequeno Édouard, filho de Villefort, ultrapassa os limites da vingança e coloca a questão moral e ética no centro: que direito Dantès tem de tomar as rédeas da situação e agir por contra própria, auto-nomear-se agente da Providência, tomar para si as prerrogativas divinas? Ao fim do romance, na carta que deixa a Maximillien e Valentine, Dantès compara-se a Satã, aquele que cai em desgraça por acreditar poder equiparar-se a Deus em autoridade.

A diferença entre a vingança tal qual vimos em Ésquilo e o modo como a compreendemos no modelo ocidental moderno e que foi cristalizada por $O$ Conde de Monte Cristo reside justamente nesse reconhecimento dos limites, da falha moral existente na vingança, ato que não é em absoluto um valor cristão - como atestam bem os versículos 35 e 36 do livro 32 de Deuteronômio do Antigo Testamento da Bíblia:

\footnotetext{
Minha é a vingança e a recompensa, ao tempo que resvalar o seu pé; porque o dia da sua ruína está próximo, e as coisas que lhes hão de suceder, se apressam a chegar. Porque o Senhor fará justiça ao seu povo, e se compadecerá de seus servos; quando vir que o poder deles se foi, e não há preso nem desamparado. (Deuteronômio 32:35-36 ${ }^{64}$ )
}

O tempo da reparação é divino, não humano, e se as relações entre deuses e homens na época de Ésquilo permitiam negociações, o deus cristão mostra-se inflexível, reservando apenas para si as prerrogativas referentes à justiça. A arrogância de Dantès é causa de sua miséria moral e existencial. Essa reviravolta faz com que Edmond, ao fim, perdoe Danglars e lhe ofereça uma chance de recomeçar - Edmond se reconhece no inimigo, vê ali um semelhante, um homem que erra; a punição passa ao plano divino, do qual se dissocia o Conde. É justamente nessa articulação entre os planos morais e a reflexão do sujeito, bem como na complexa teia de percursos narrativos usados para dar corpo à narrativa de vingança, que $O$ Conde de Monte Cristo se estabelece como um ponto de referência no tesouro cultural do ocidente.

$\mathrm{Na}$ adaptação cinematográfica de 2002, dirigida por Kevin Reynolds, a heresia da vingança é pronunciada desde o início. Diferente do livro, cujo foco narrativo é distribuído por todas as personagens, no filme a narrativa se dá o tempo todo sob o ponto de vista de Dantès, que nunca é escondido do espectador - os jogos de luz e sombra ocorrem apenas

\footnotetext{
${ }^{64} \mathrm{http}: / / \mathrm{www}$. bibliaonline.com.br/acf/dt/32 (Acessado em 14/10/2014).
} 
diante dos olhos da sociedade parisiense. Jacopo, o conselheiro de Dantès, que no livro fica ausente a maior parte do tempo, a todo momento tenta dissuadi-lo, como já fizera o Abade Faria no Castelo de If, de seus planos de vingança. A ideia latente é a de que atentar contra o outro é atentar contra si mesmo, pois tomar para si as prerrogativas divinas é conspurcar a própria alma. A cada passo, Dantès se distancia da própria felicidade e caminha obstinadamente para a própria destruição a ponto de quase matar Albert (que na adaptação é seu filho com Mercedes).

A opção no último momento por perdoar Fernand oferece a chance de redenção a Dantès e o coloca novamente no mundo dos homens, em uma nova relação de alteridade. Assim como no livro, o perdão surge a partir da restauração das relações intersubjetivas contratuais que haviam sido quebradas por meio da ofensa originadora da vingança obstinada à qual Dantès se dedicava desde a fuga do Castelo de If. A máscara do Conde de Monte Cristo, que representava um objeto, uma peça no tabuleiro, que poderia ser movida para elaborar as estratégias, é quebrada e cede lugar ao sujeito vulnerável, que permite uma nova relação, com novas possibilidades. Nesse sentido, o percurso da vingança é uma amarra que limita o campo de ação do sujeito e o restringe ao mundo das sombras, do que é deixado de lado pela sociedade - aqui cabe a leitura que Freud (1976) faz do tema do Estranho, posto que a vingança, tal como trabalhada no romance e no filme, é algo terrível, temido, que persegue os sujeitos, apesar de todas as tentativas de recalque.

$\mathrm{O}$ retorno daquilo que se considerava extinto é tema que se alia ao da vingança e encontra em $O$ Conde de Monte Cristo uma das formulações mais célebres na cultura ocidental. Há algo de sobre-humano nos temores relatados por Freud e, com efeito, o Conde nos passa essa mesma sensação: extremamente rico, fluente em diversas línguas, versado nas mais diversas ciências e exímio esgrimista e atirador, Monte Cristo é ao mesmo tempo encantador e terrível. Além disso, há os diversos disfarces, os duplos de Dantès espalhados pelo romance, que confundem até mesmo o leitor - só em um estágio adiantado ficamos sabendo que o Abade Busoni, Lord Willmore e Simbad, o Marujo, são a mesma pessoa. O mal estar causado pelo Conde a Franz d'Épinay e à Condessa G (que o confunde com um vampiro) é sintomático dessa estranheza oriunda do jogo de luz e sombra imposto pelo romance. No entanto, o medo vem acompanhado do fascínio e assim Monte Cristo consegue colocar todos onde quer e transforma a sociedade parisiense em uma máquina que funciona a seu comando para produzir sua vingança. 
Essa transformação de humano em sobre-humano é um exemplo patente de percurso de uso que havíamos mencionado na seção anterior, conferindo ao sujeito os meios de realização de sua performance. Na superfície do discurso, isso aparece figurativizado por meio das riquezas, do luxo, do regime de estudos imposto pelo Abade Faria - se considerarmos a adaptação cinematográfica, o treinamento de Dantès ocupa boa parte da primeira metade do longa-metragem, demonstrando um pareamento entre expressão e conteúdo. No caso do livro, as escolhas de distribuição dos elementos discursivos no enredo marcam bem a variação tensiva de andamento, que perpassa todos os níveis do percurso gerativo.

Como apontado nestas poucas páginas, o percurso do vingativo moderno é bem diferente do que se vê na Grécia, em que basta um pequeno ardil e um confronto para lavar com sangue a honra. Trata-se, agora, de uma elevação espiritual e material do sujeito que, como dissemos, aparta-se das relações intersubjetivas e aproxima-se do divino, onde encontra, ironicamente, sua derrocada ao igualar-se a Satã. A vingança é atributo dos marginalizados, que pacientemente precisam infiltrar-se e dominar a máquina social de modo a impor sua visão de justiça. No entanto, a derrocada do outro gera a própria destruição e ameaça a todos os que o cercam. Outras obras de ficção, como a série televisiva Revenge, criada por Mike Kelley, e a graphic novel $V$ de Vingança, de Alan Moore e David Lloyd, corroboram nossas hipóteses. Vejamos, com mais vagar, como esse complexo tensivo-discursivo-textual é organizado em Final Fantasy XIII.

\subsection{A vingança como ideia fixa e negação da alteridade}

À primeira vista, a linearidade do jogo mencionada algumas páginas atrás parece ser o aspecto mais evidente da relação entre expressão e conteúdo no caso da representação da vingança em Final Fantasy XIII: sendo uma paixão que arrebata o corpo do sujeito de maneira tônica, imprimindo uma redução de foco perceptivo do espaço como um todo seja no campo de ação, seja nas relações intersubjetivas -, restringir as possibilidadas de jogo a uma progressão em linha reta expressa com bastante eficiência esse arranjo de conteúdo.

O percurso de aquisição de competência é encenado na dinâmica de evolução de personagens, feita por meio das batalhas sucessivas e do investimento dos pontos recebidos em habilidades e atributos, como demonstrado nas imagens abaixo: 


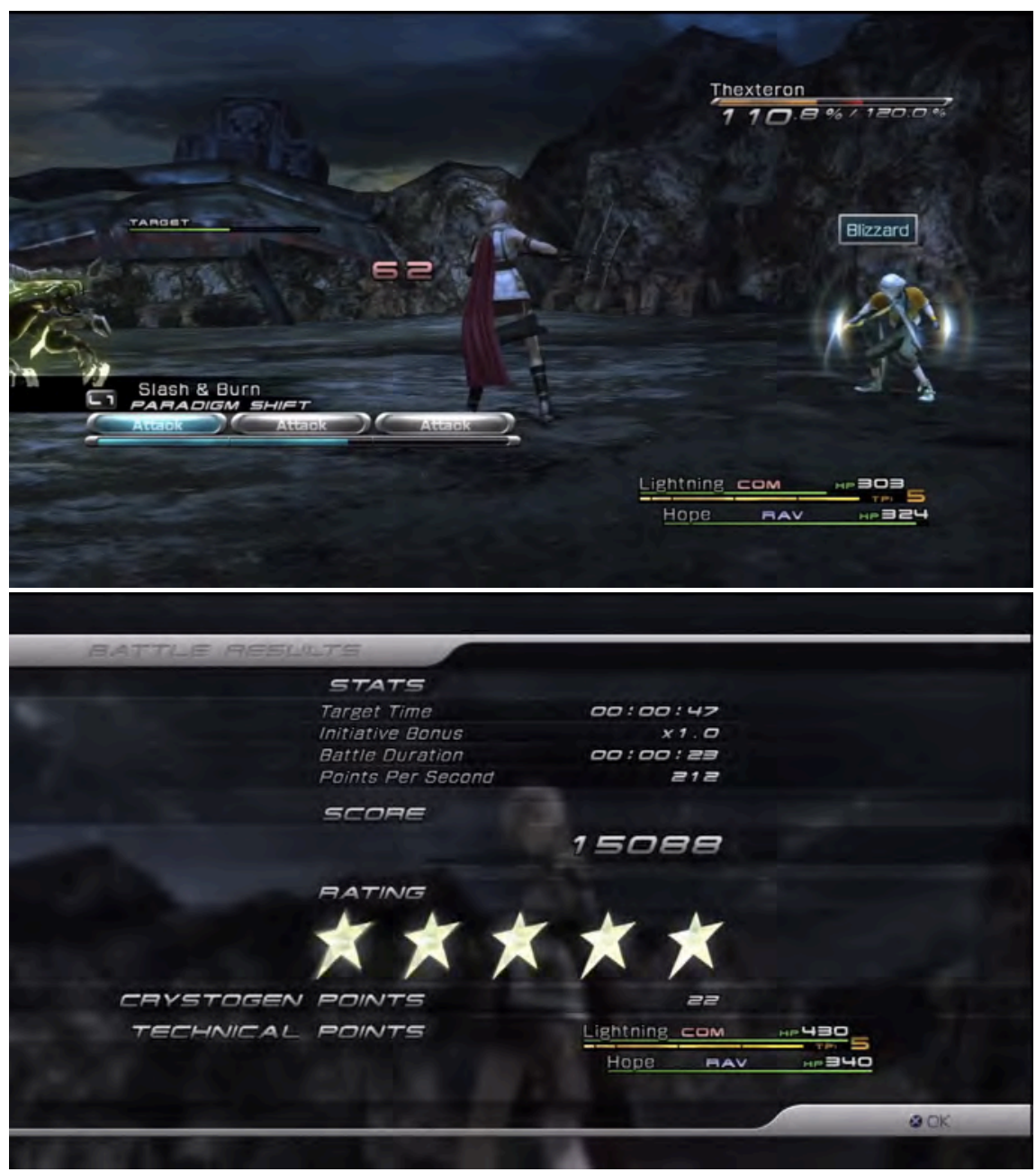

(Figuras 137 e 138: dinâmica de batalha, com obtenção de Crystogen Points)

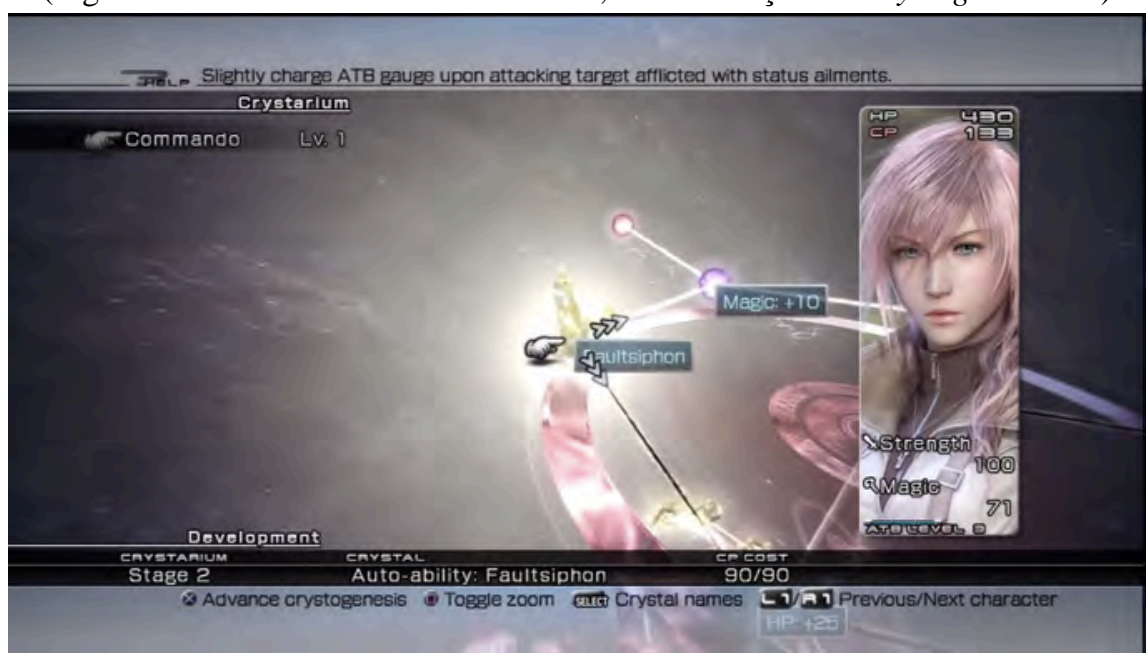




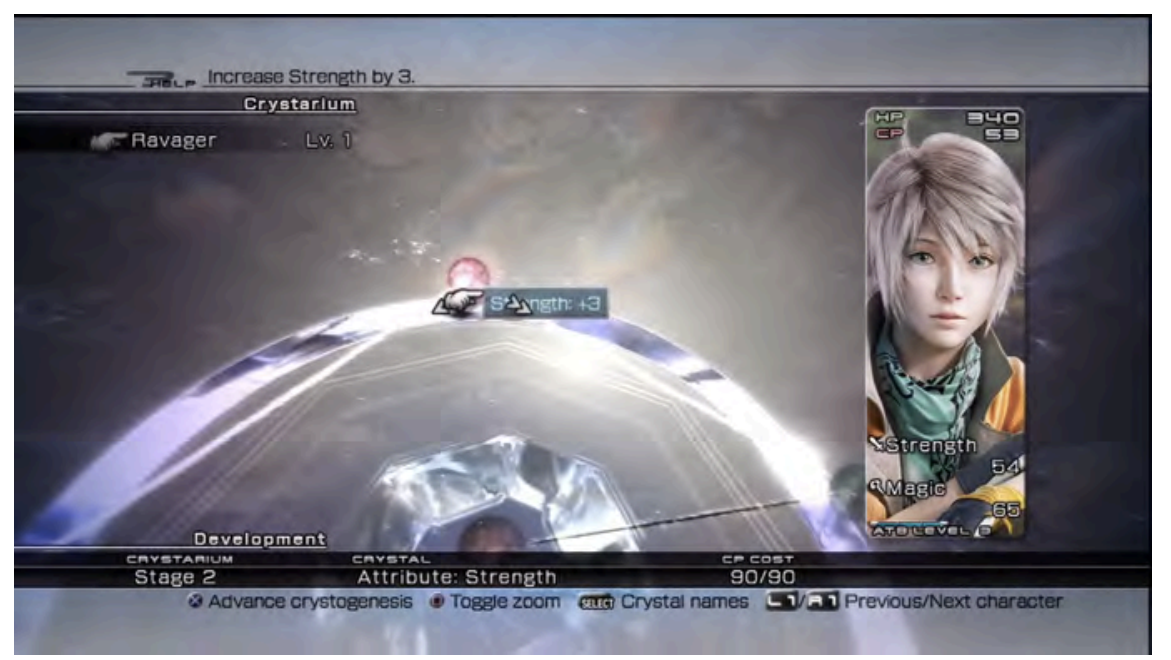

(Figuras 139 e 140: o Crystarium, no qual o jogador investe os pontos obtidos para evoluir as personagens)

As classes disponíveis para cada personagem e a quantidade de habilidades se expandem à medida que o jogador avança e os estados de jogo vão se modificando. Esse constante ajuste, até certo ponto personalizável, confere um andamento desacelerado em relação a outros jogos da série, em que cada evolução conferia automaticamente as melhorias a cada personagem; ao mesmo tempo, a existência de um teto evolutivo em cada estado de jogo faz com que não seja atraente permanecer muito tempo em um mesmo lugar acumulando pontos - em algum momento, será impossível investir mais nas personagens. Essa característica de Final Fantasy XIII compele o jogador a seguir em frente no jogo e, consequentemente, desenvolver o percurso narrativo do plano do conteúdo; trata-se, em suma, de restringir o campo de ação e manter o foco "no que interessa", na meta de vingança que as personagens se impõem.

Embora o foco pareça acelerar o andamento, as constantes mudanças de estado de jogo fazem com que as personagens controladas se alternem e outros percursos sejam desenvolvidos em concomitância, gerando uma desaceleração, portanto. Apesar disso, os procedimentos são organizados segundo os mesmos critérios independentemente das personagens em foco, mantendo as tensões valenciais que identificamos com a vingança ${ }^{65}$.

As interações entre Lightning e Hope não configuram, inicialmente, uma relação de intersubjetividade. O garoto olha para a ex-militar como uma fonte de conhecimento, um

\footnotetext{
${ }^{65} \mathrm{O}$ jogo apresenta outros complexos patêmicos, como obstinação e resignação, os quais apresentam uma configuração tensivo-narrativa bastante similar. Esses outros percursos não figuram aqui em virtude da extensão exigida para tratá-los adequadamente - um capítulo seria insuficiente para lidar com mais de uma paixão.
} 
mero meio de obter a competência necessária para sua performance; Lightning, por sua vez, enxerga Hope como um empecilho ${ }^{66}$.

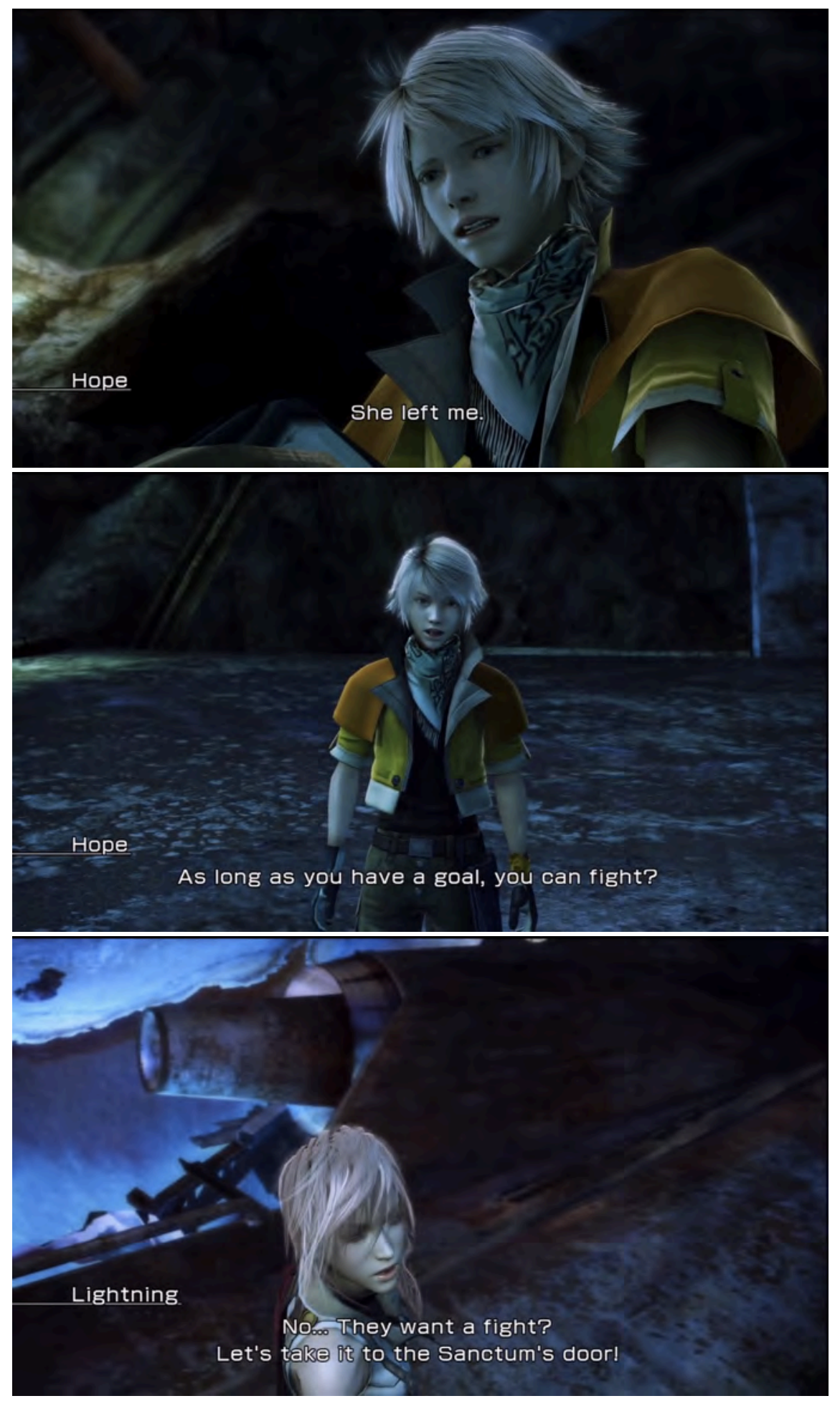

\footnotetext{
${ }^{66}$ As imagens foram retiradas de momentos diferentes do jogo e, mesmo que colocadas uma abaixo da outra, não correspondem necessariamente a elementos de um mesmo diálogo ou de uma mesma cutscene.
} 

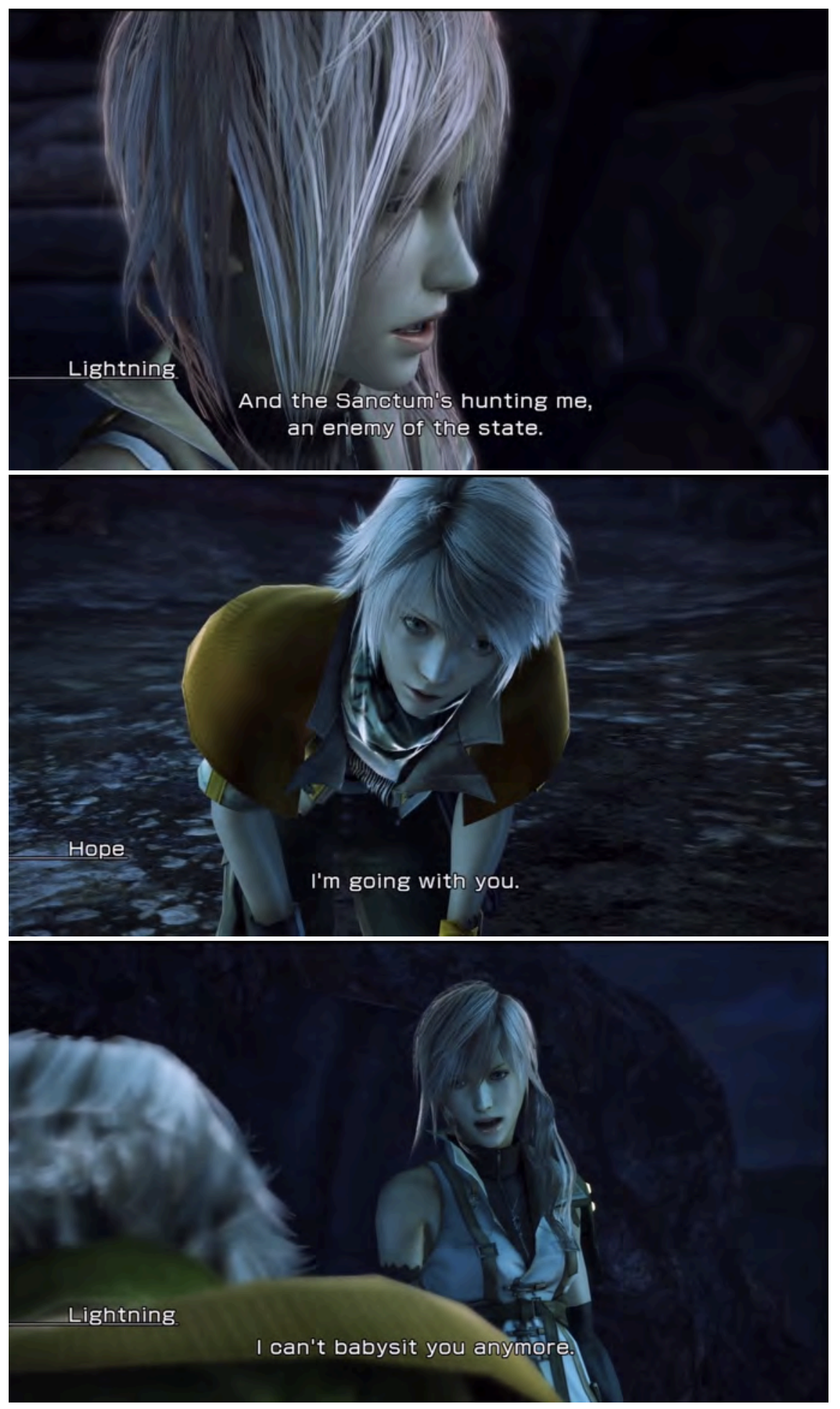

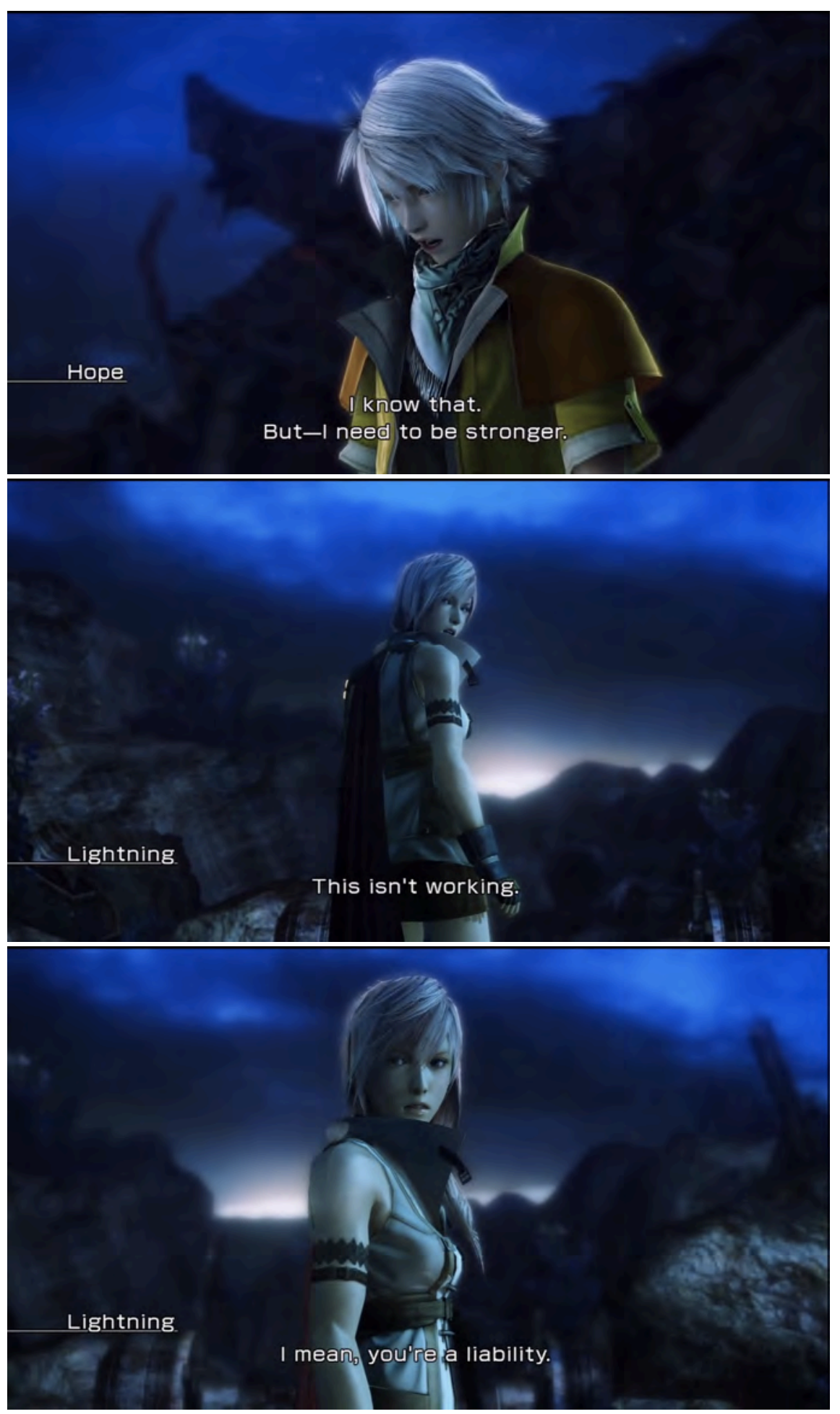

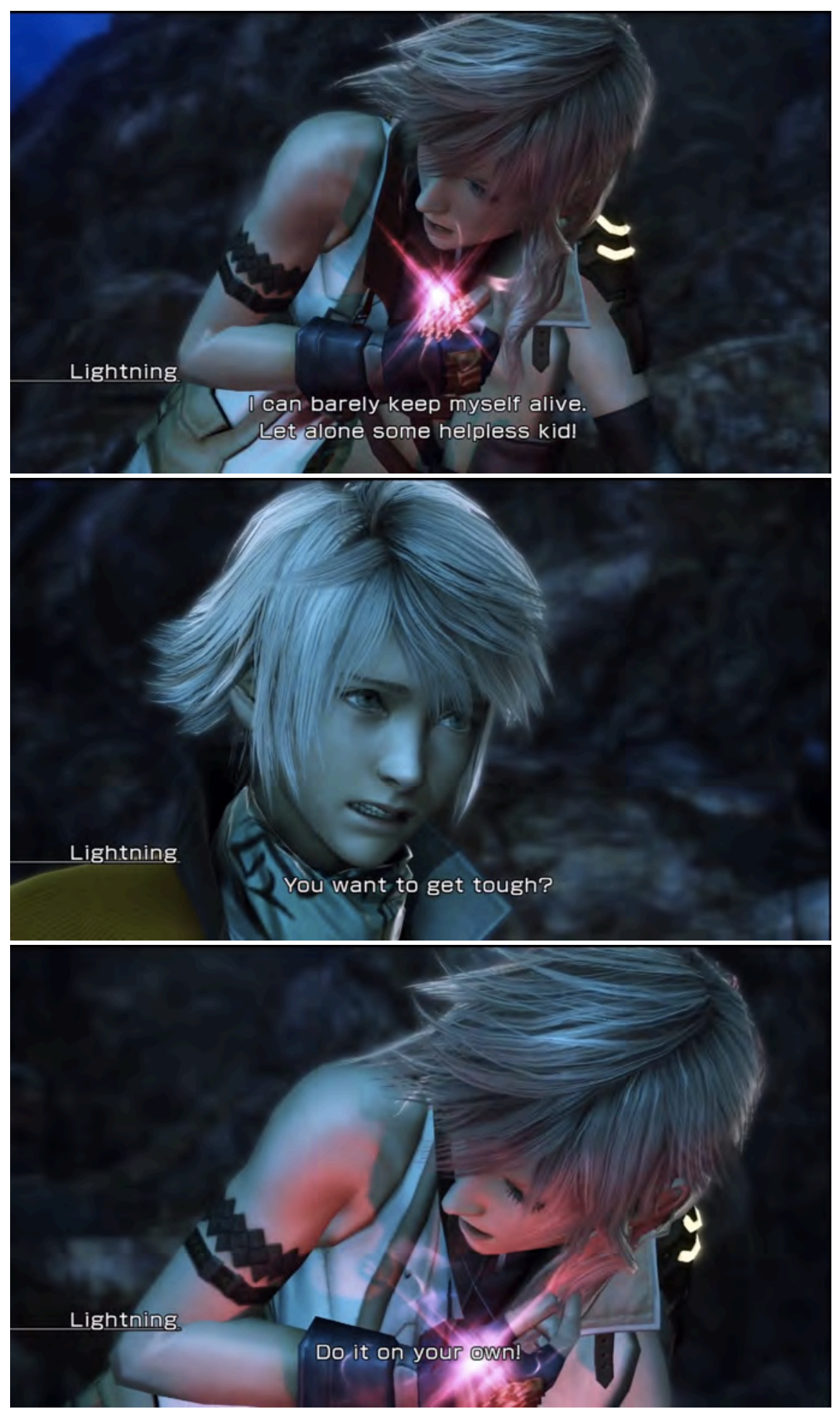

(Figuras 141 a 152: relações polêmicas entre Lightning e Hope)

A modalidade de grupo é bastante significativa nesse aspecto: enquanto Lightning é a líder (efetivamente é quem o jogador controla), Hope a segue agindo de acordo com as classes disponíveis - suporte, em sua maioria. Toda a estratégia de batalha é feita a partir de Lightning. 
Pouco a pouco, a relação entre ambas as personagens começa a mudar e a alteridade se instaura:
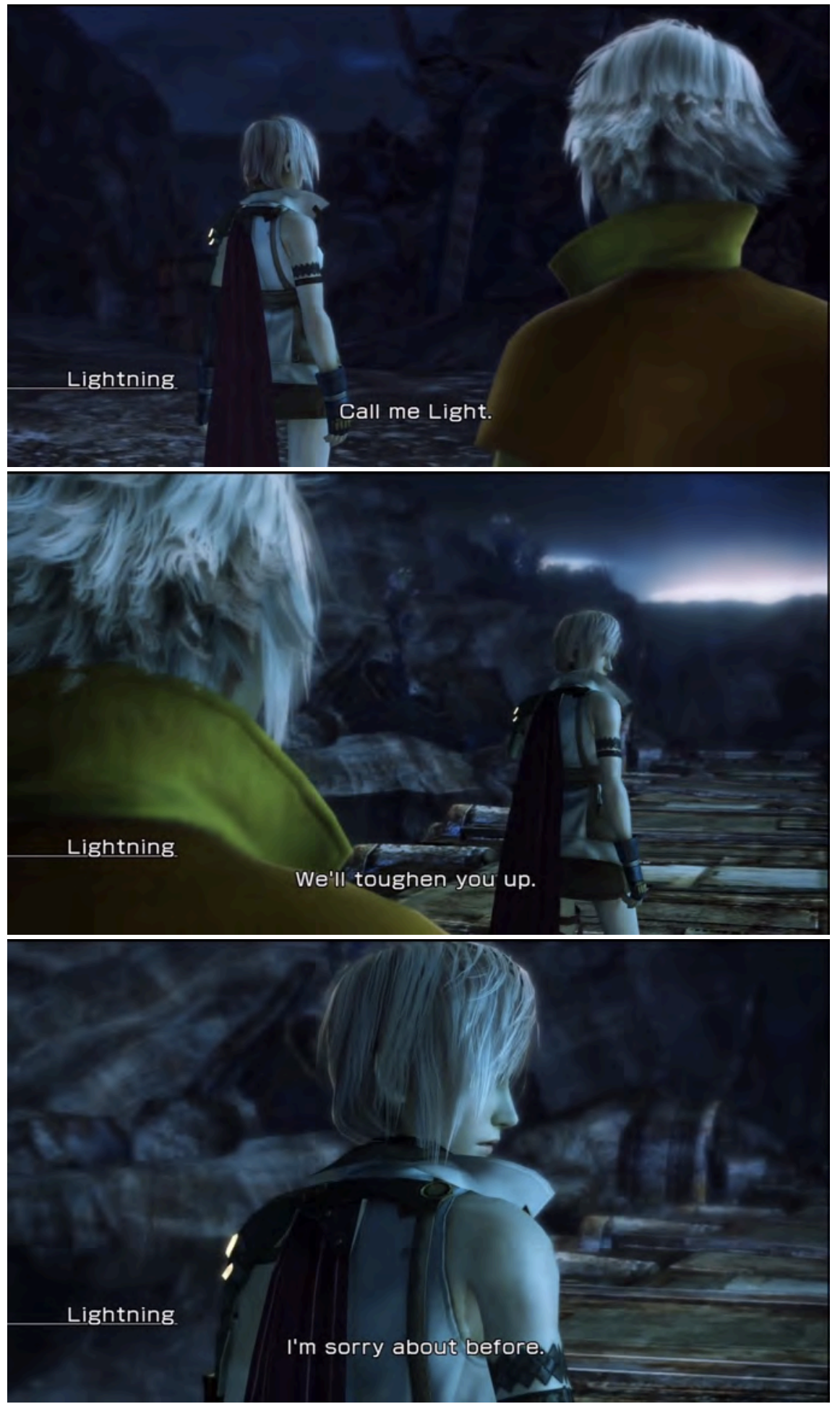

(Figuras 153 a 155: início das relações de alteridade)

Não por acaso, o jogador passa a assumir o controle de Hope quando Lightining passa a reconhecê-lo como sujeito: 


\section{3}

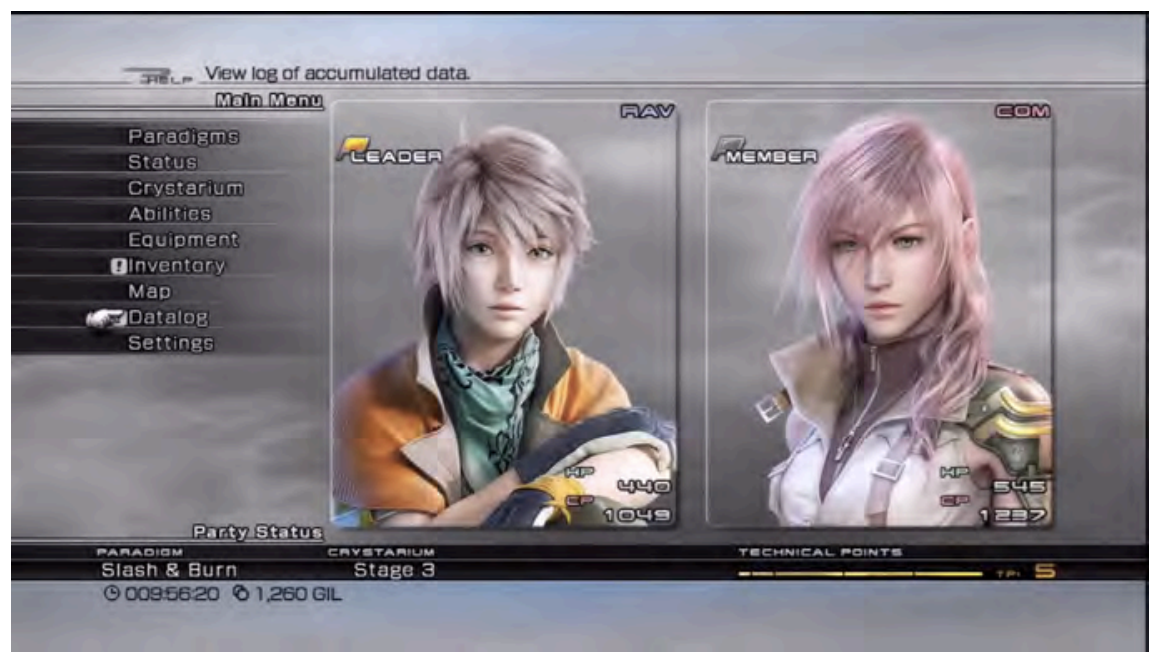

(Figura 156: menu do jogador indicando Hope como a personagem efetivamente controlada)
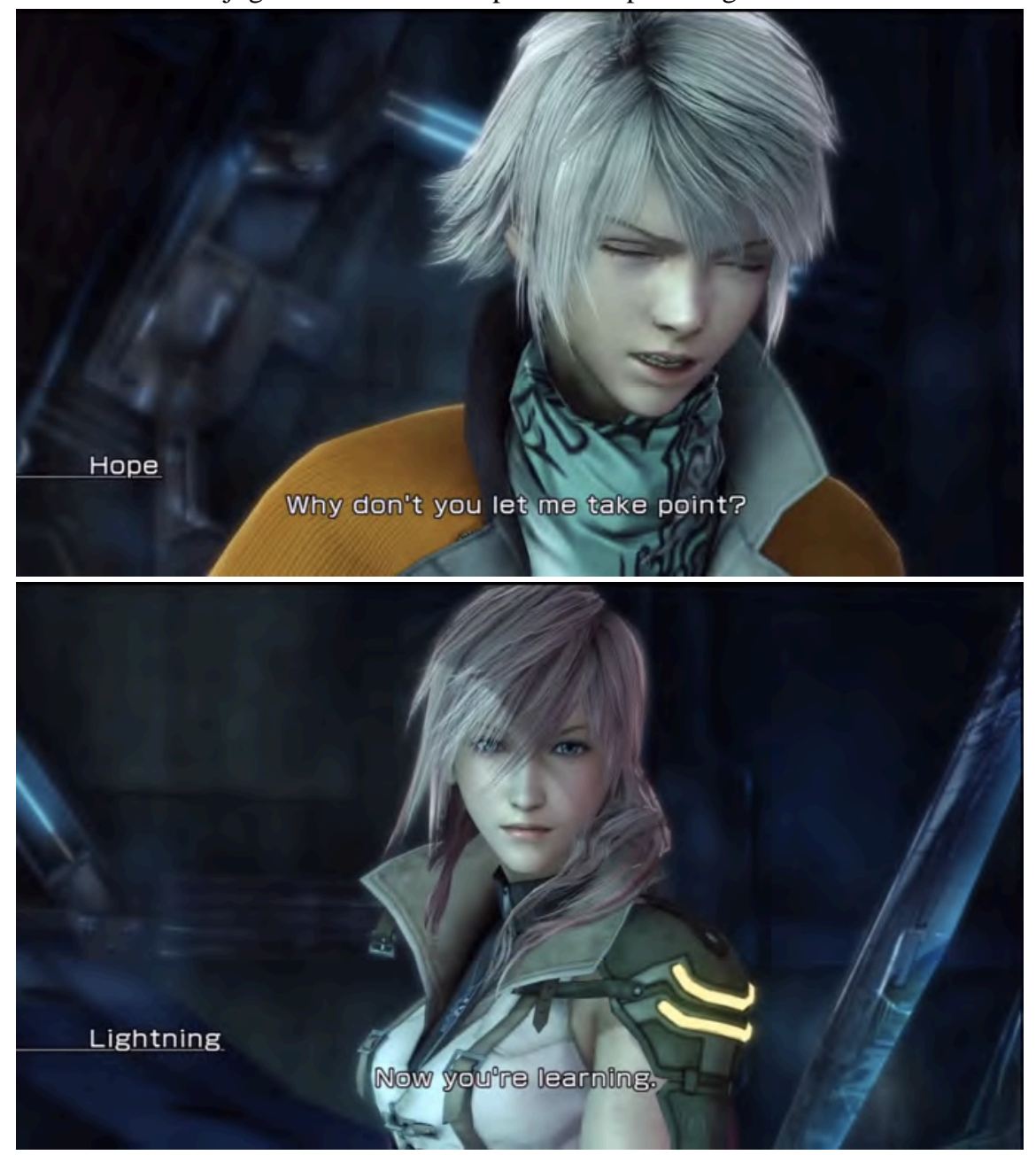

(Figuras 157 e 158: reconhecimento da alteridade) 

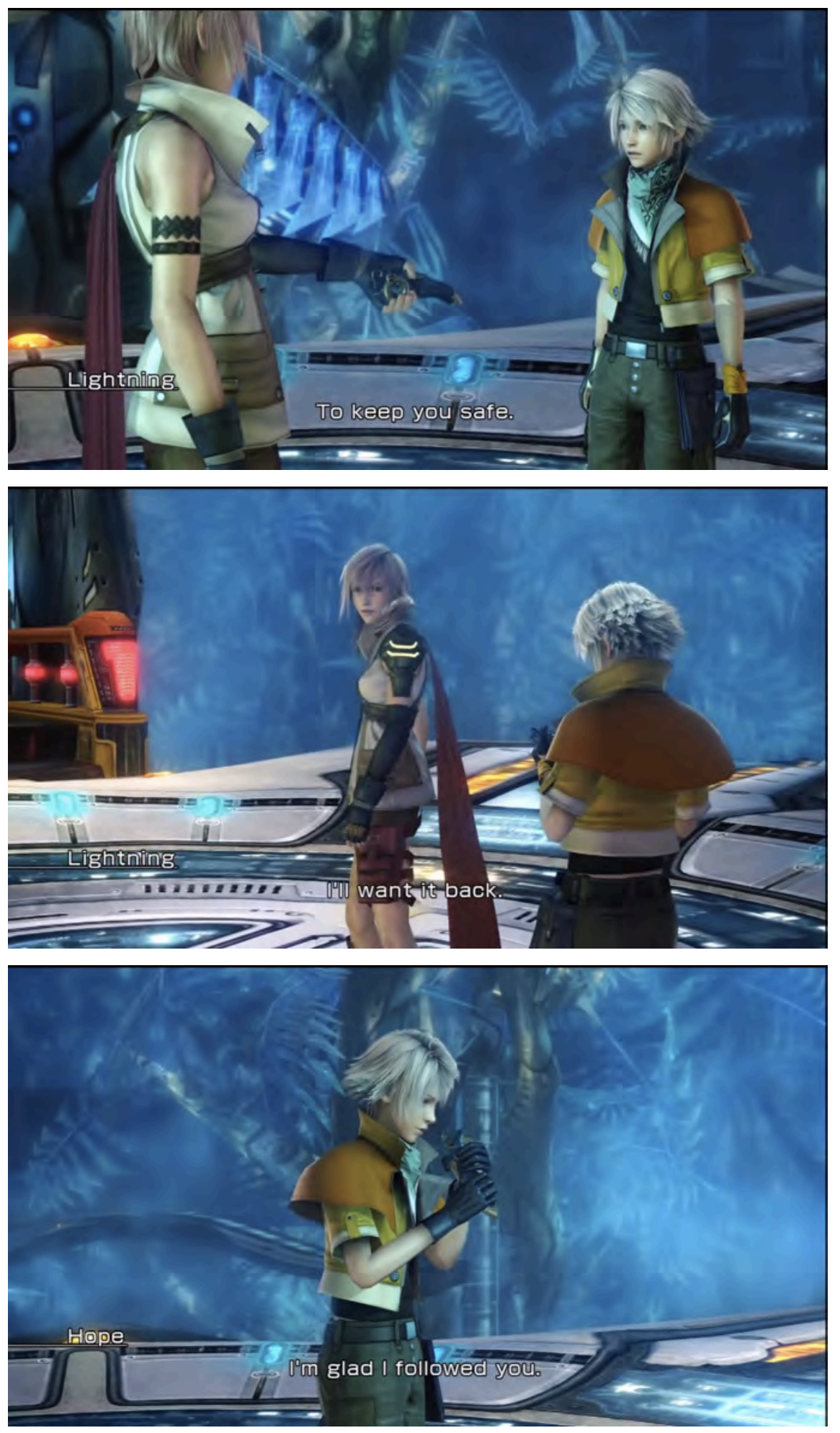

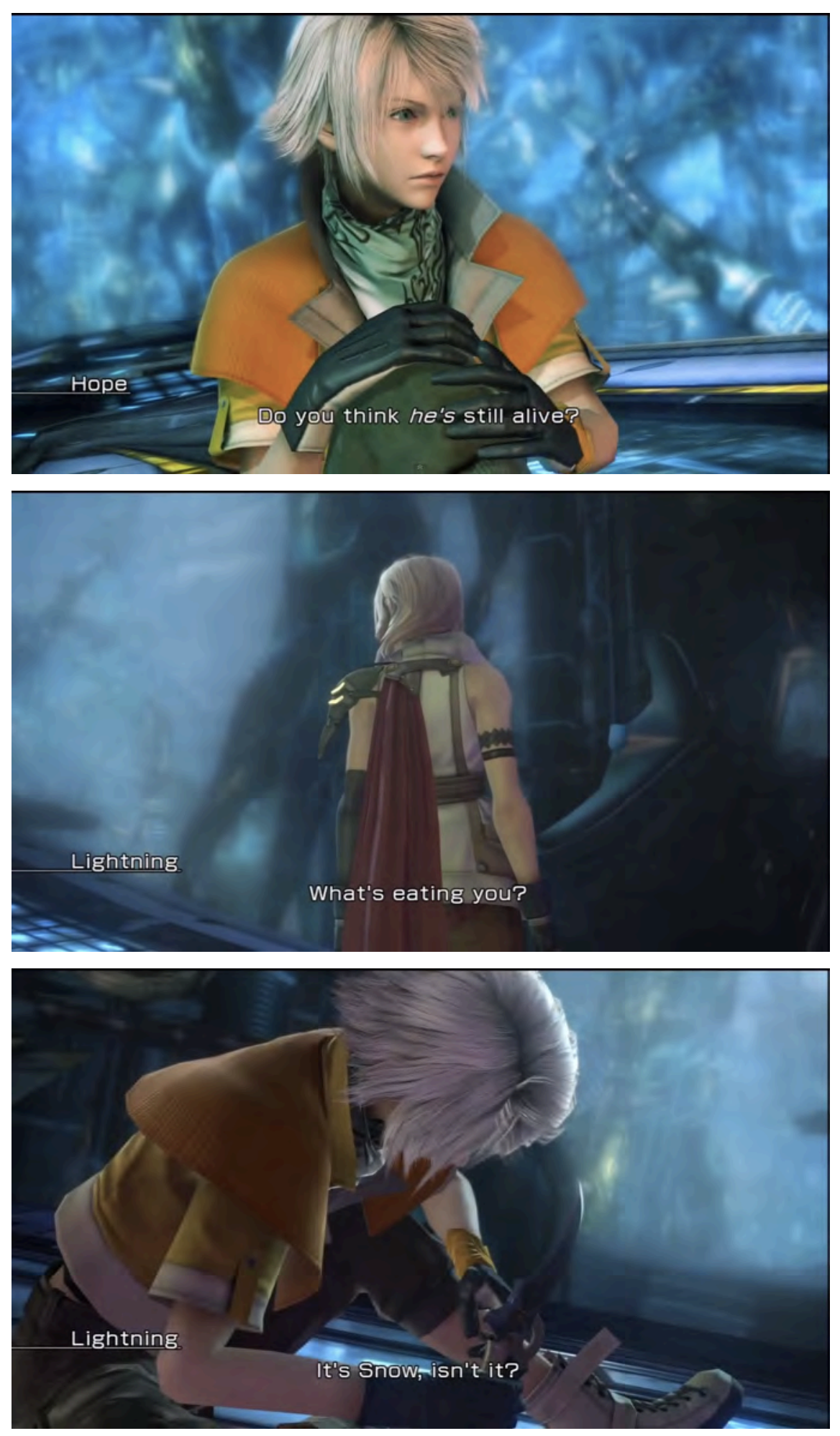

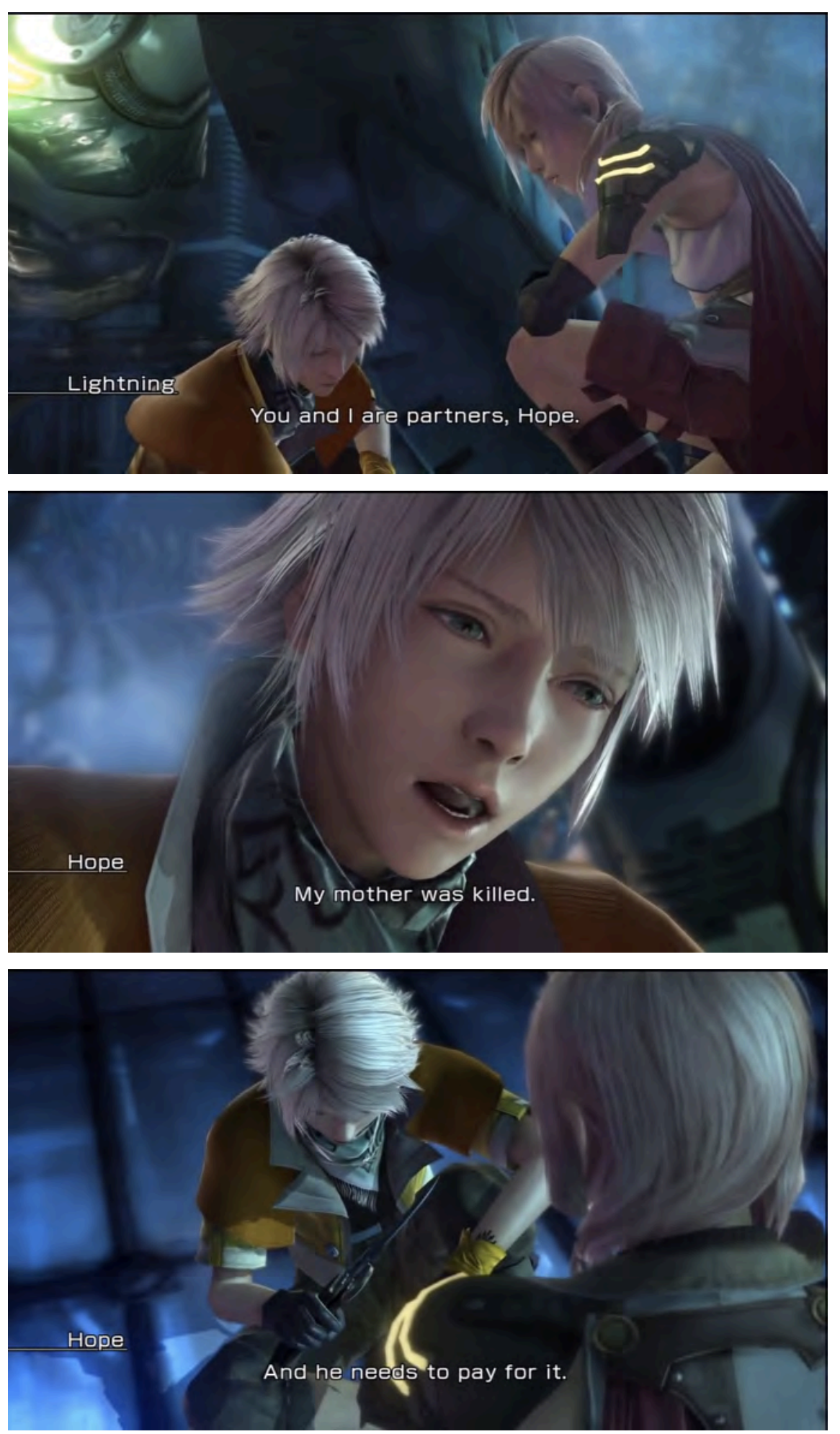

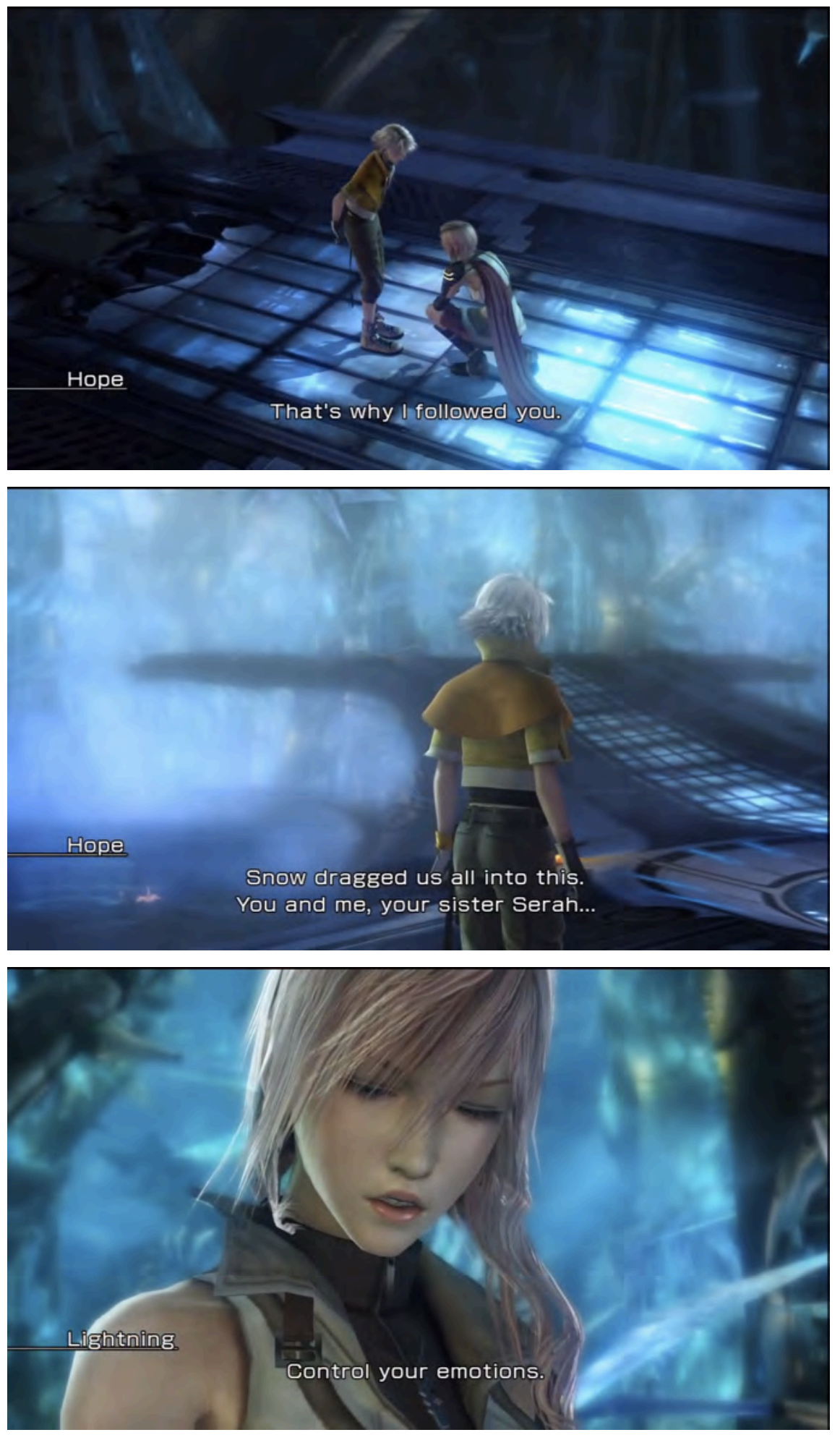

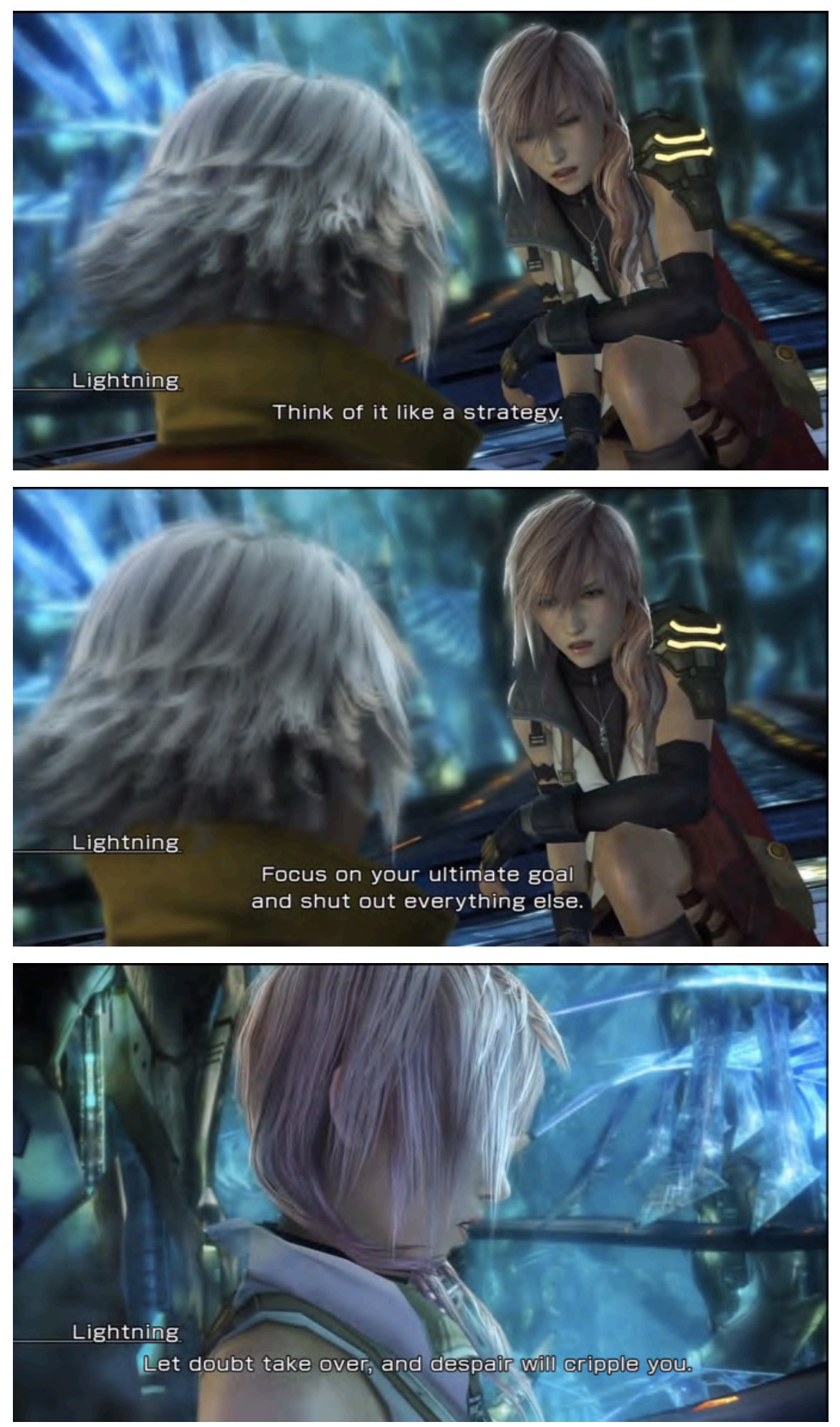

(Figuras 159 a 173: conselhos, reconhecimento do outro como um eu e exaltação da alteridade)

A alteridade começa a dissipar os desejos de vingança à medida que as personagens começam a vislumbrar novas formas de existência para além da estereotipia passional e/ou passam a ver os alvos de sua vingança sob outro prisma: 


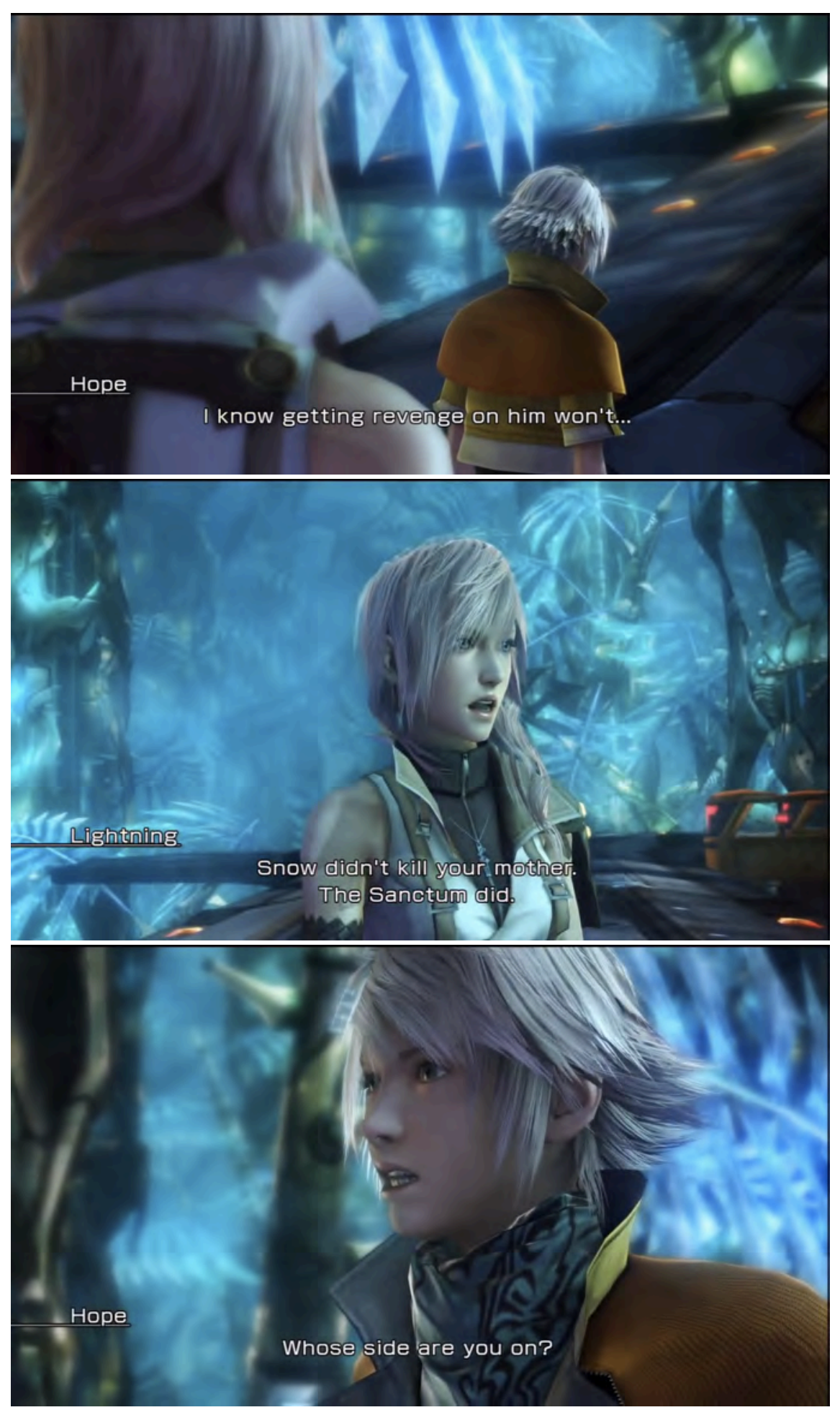



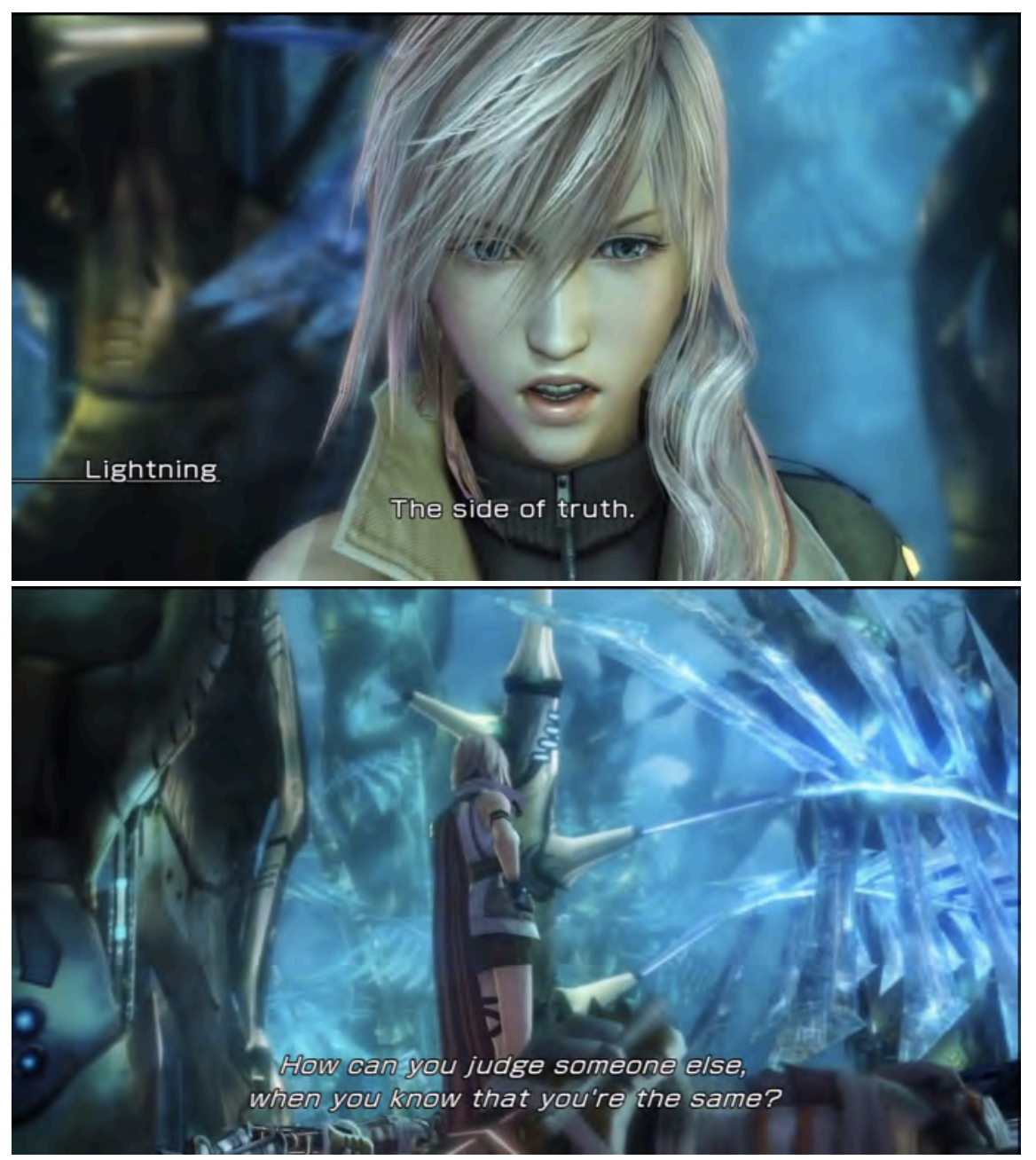

(Figuras: 174 a 178: alteridade e ampliação da visão como obstáculos pra vingança)

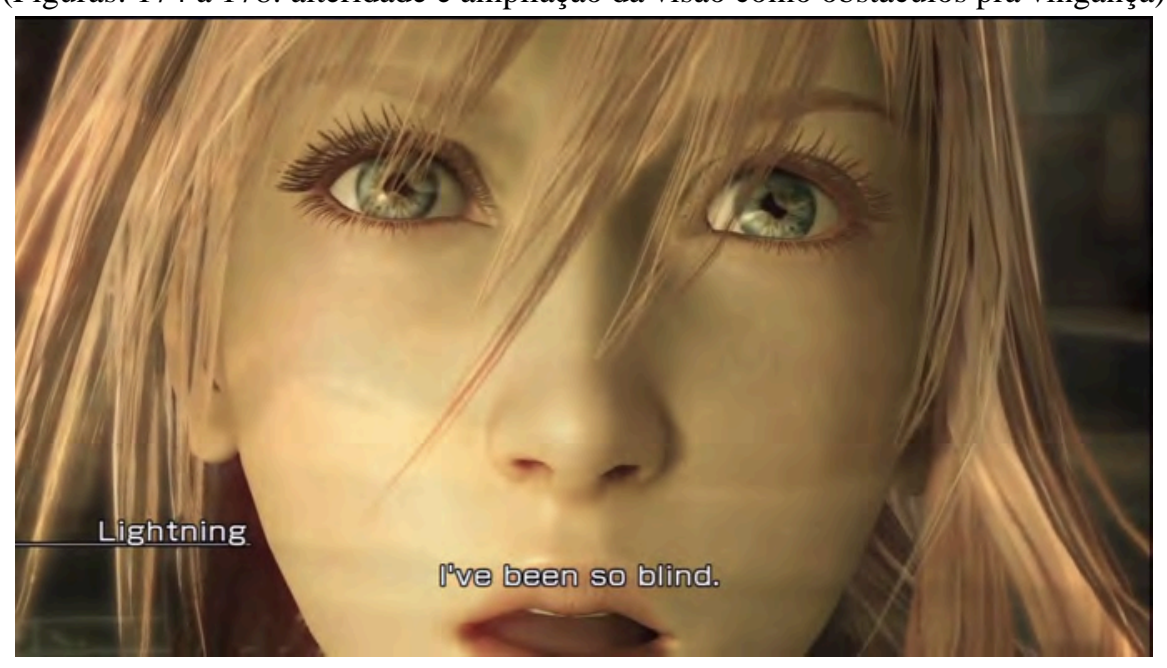



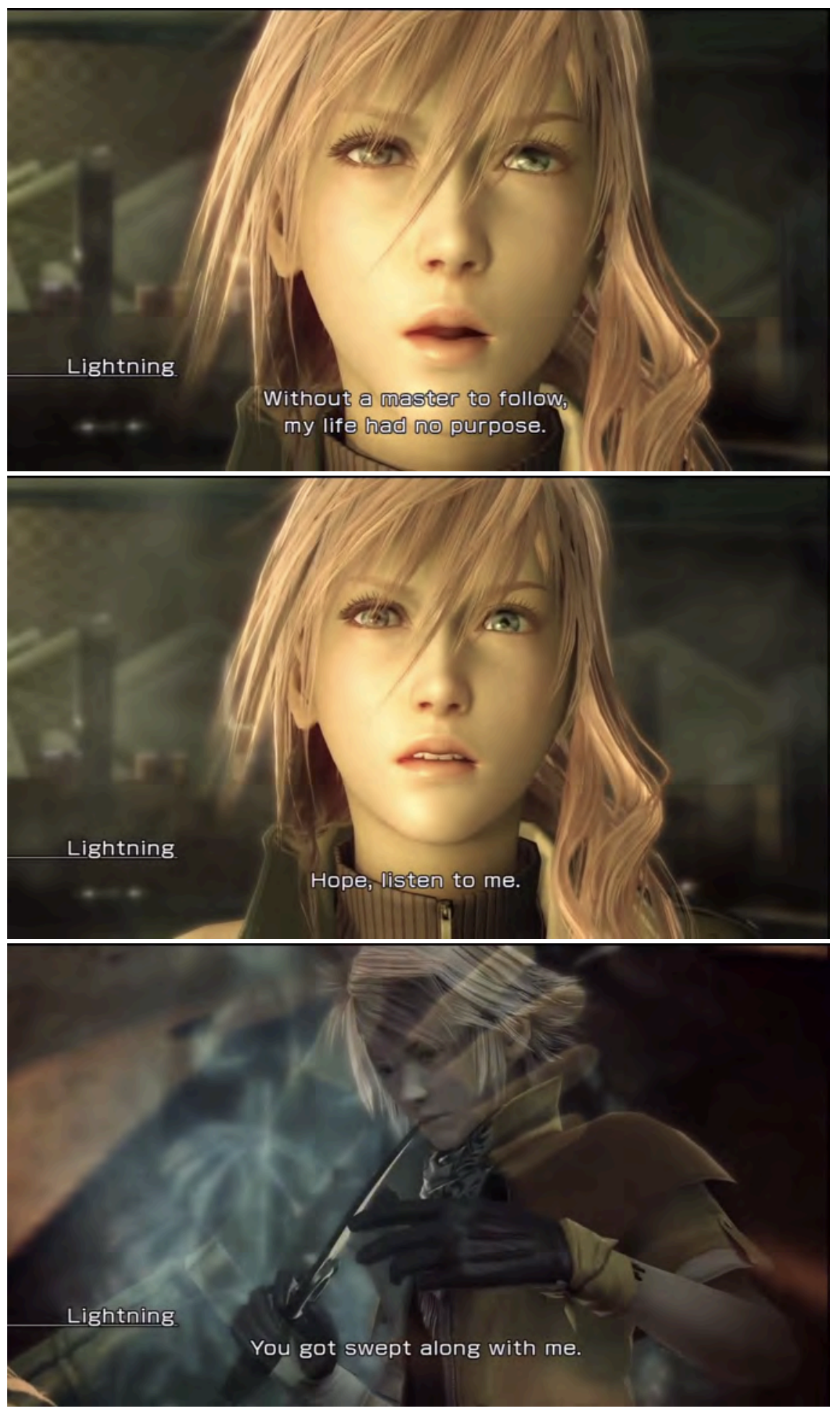


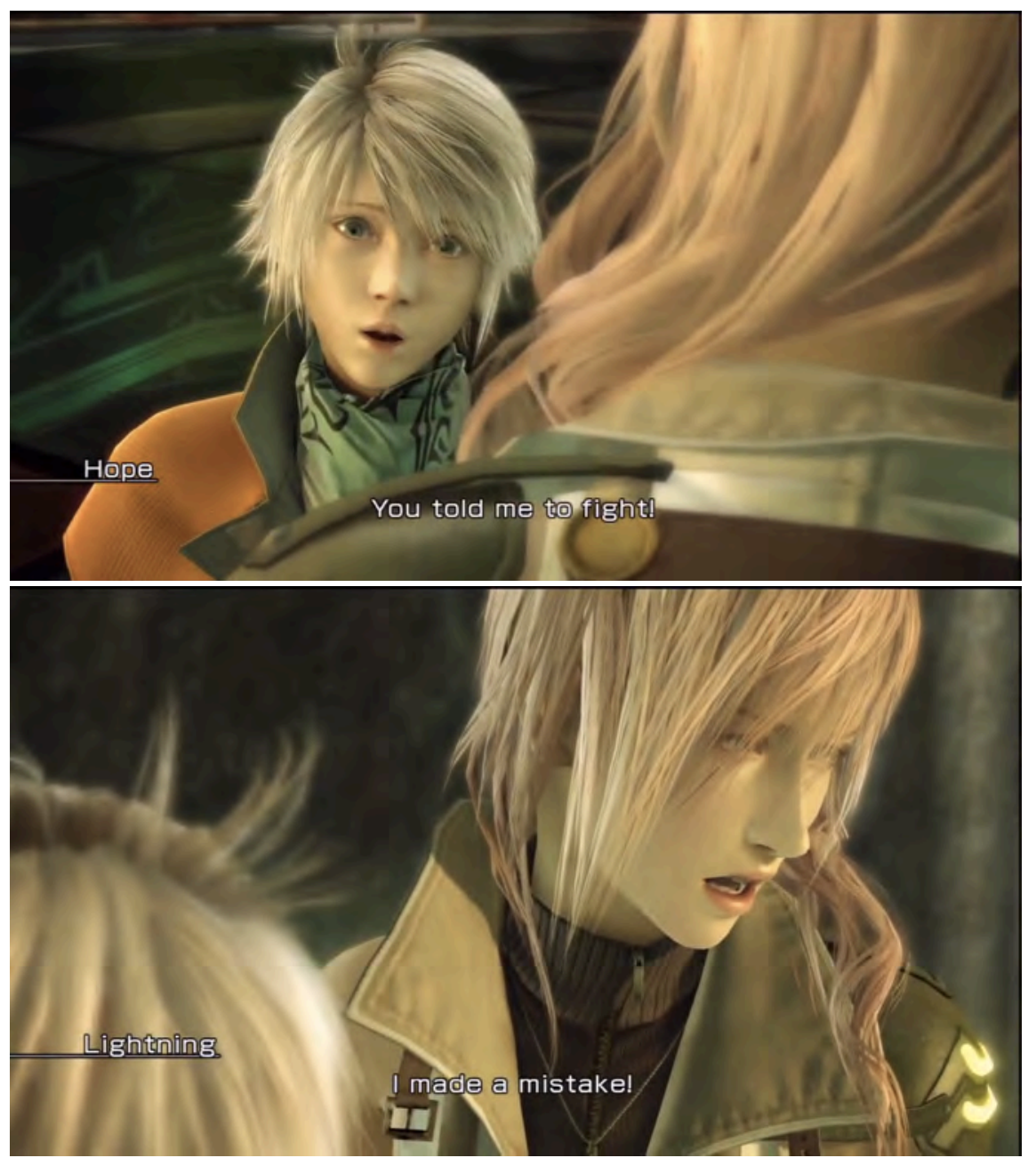

(179 a 184: reconhecimento da visão limitada como uma das fontes da vingança)

Isso fica mais forte quando ocorre uma mudança de estado de jogo e as personagens são agrupadas da seguinte forma: Lightning e Fang, Snow e Hope. A convivência, forçada no início, cria as condições para a instauração total das relações intersubjetivas:

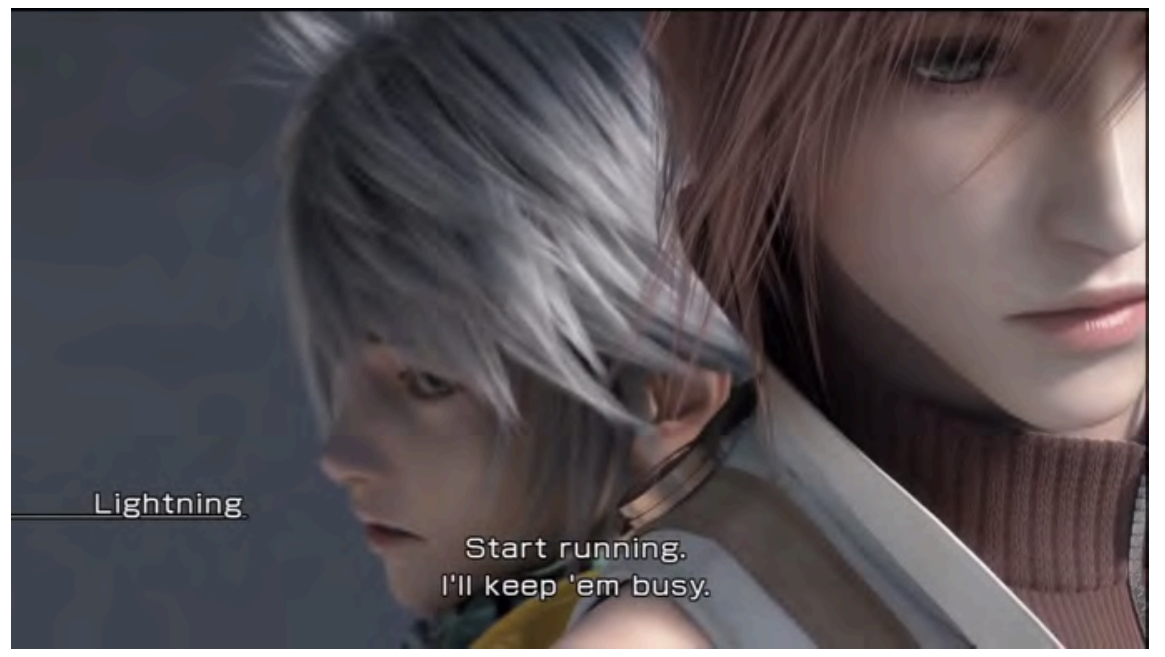



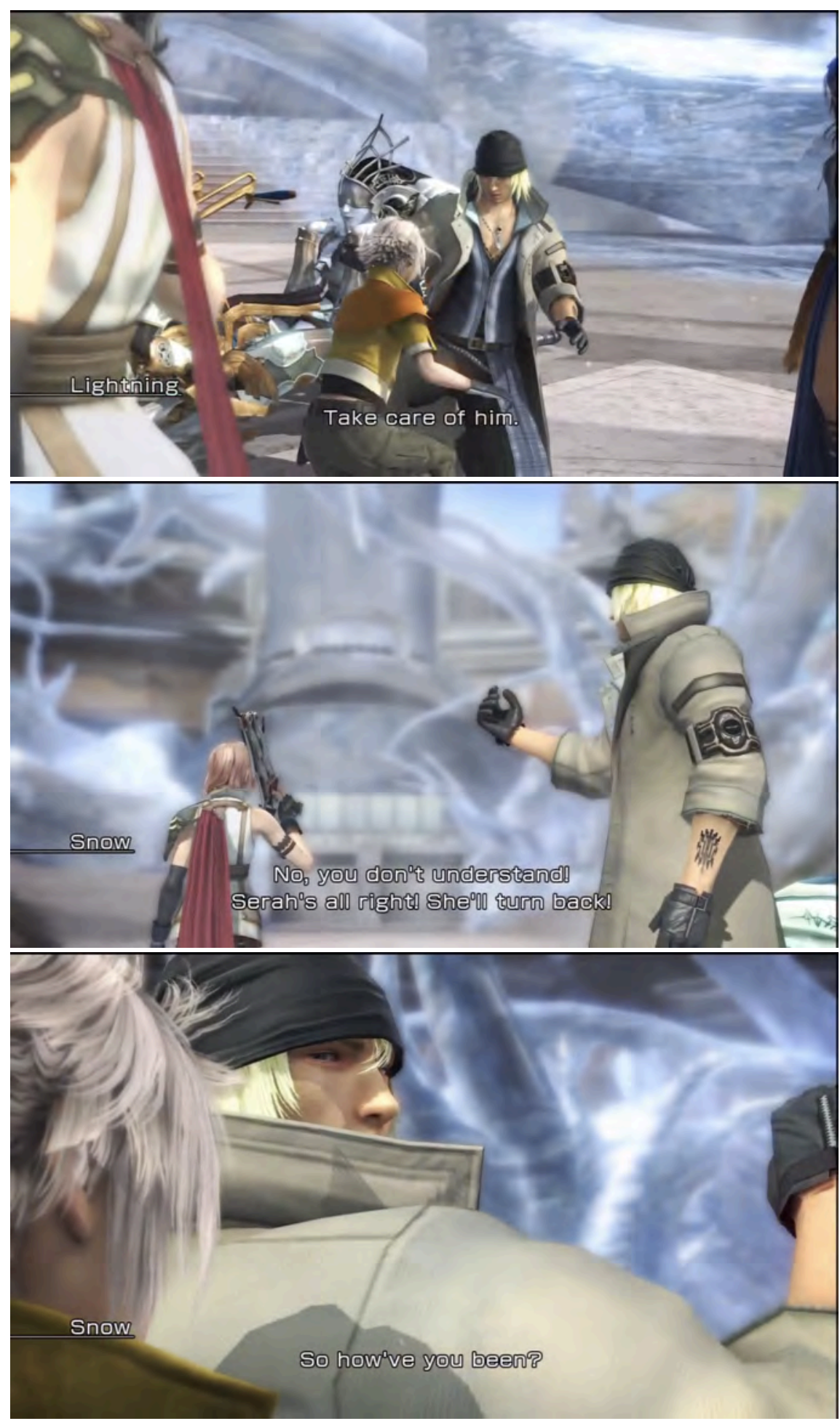

(Figuras 185 a 188: cutscene que marca a mudança de estado e, consequentemente, a dos grupos) 


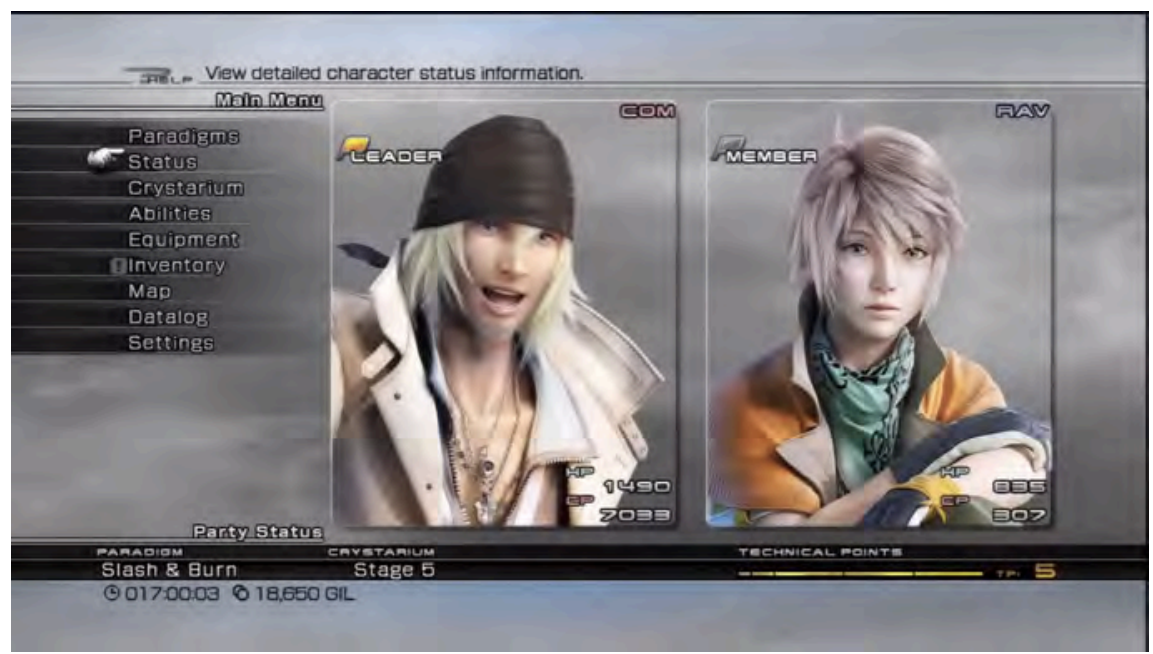

(Figura 189: menu do jogador após a cutscene, indicando Snow como a personagem efetivamente controlada)
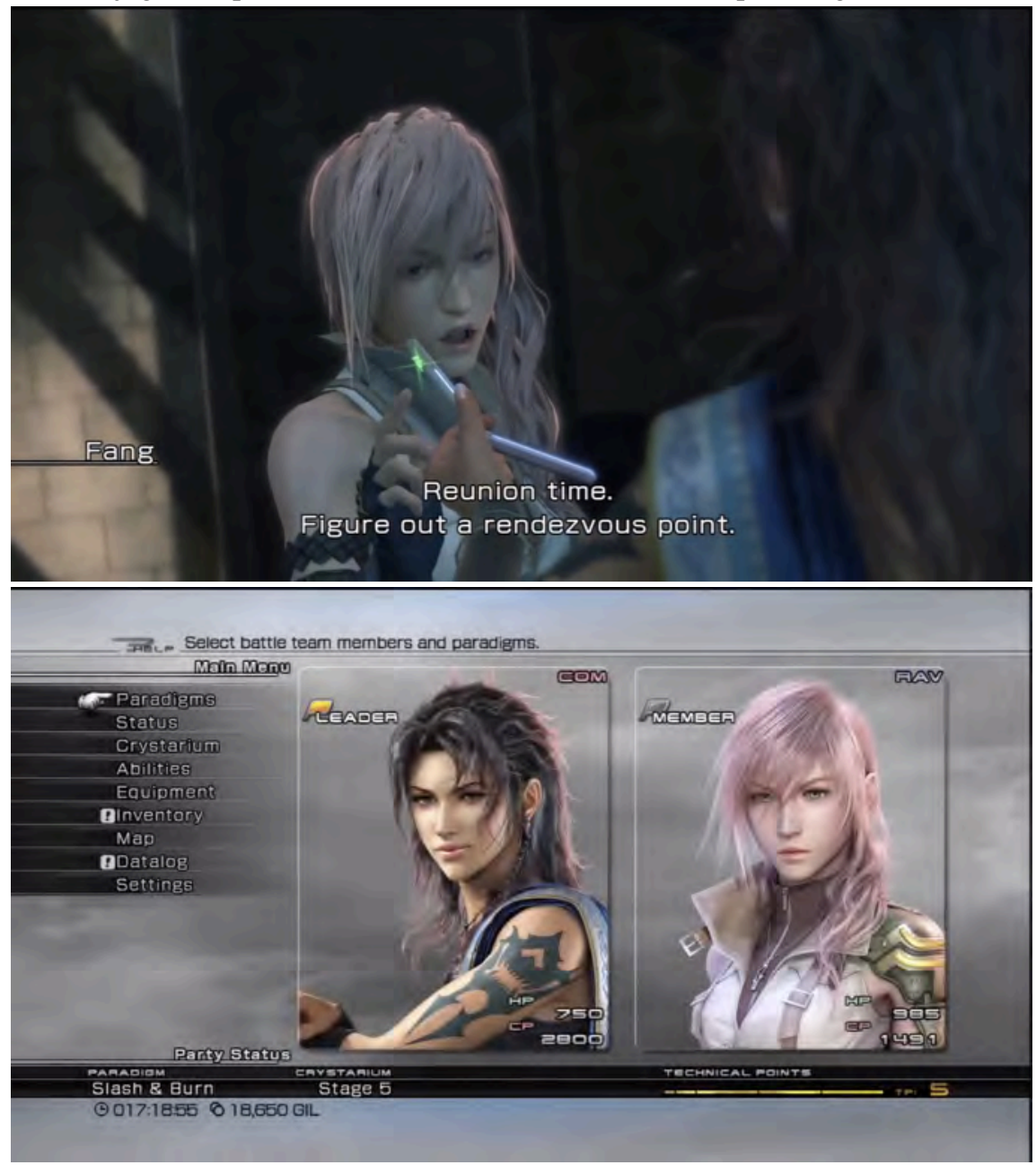

(Figuras 190 e 191: mudança de estado após cutscene, indicando Fang como líder) 

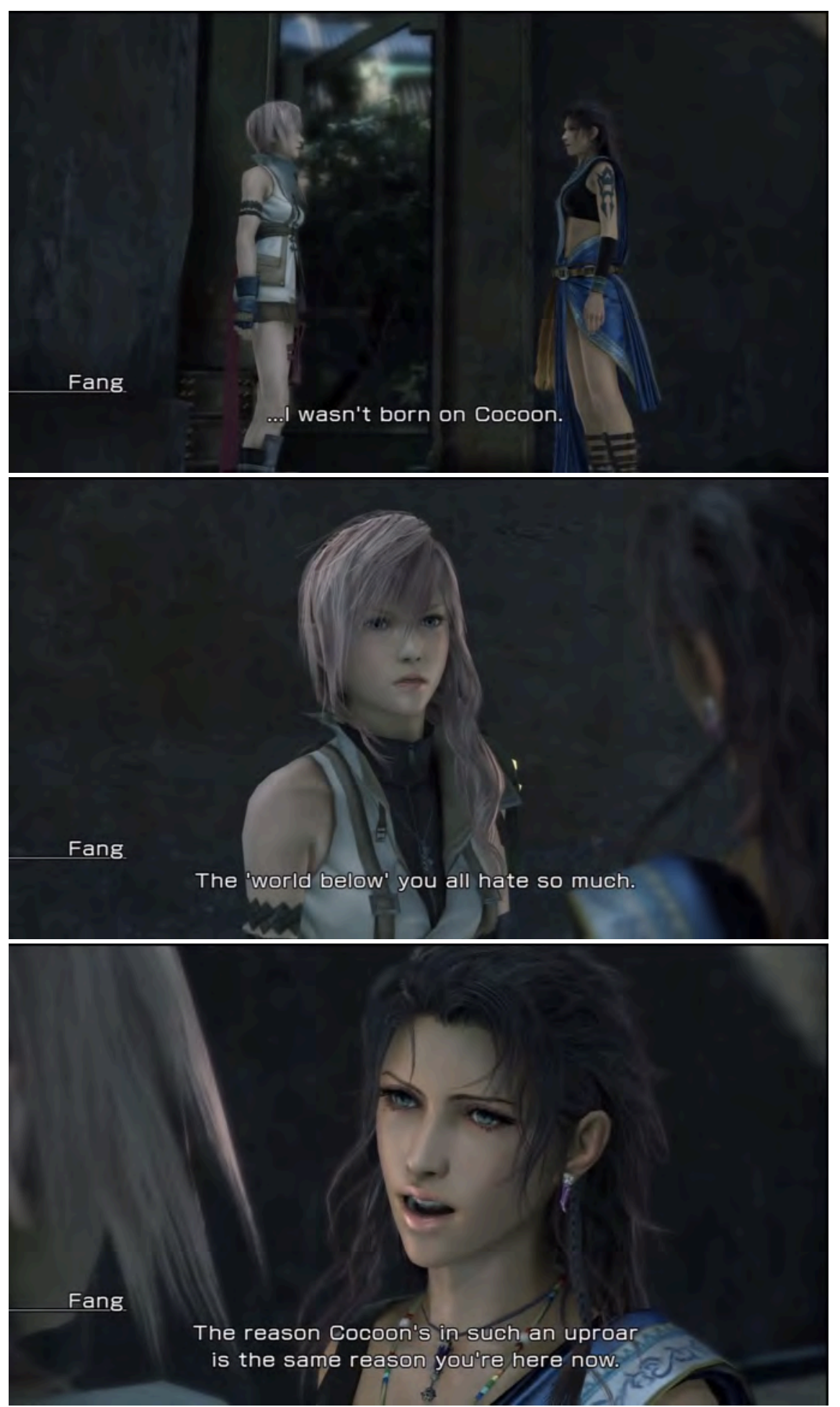

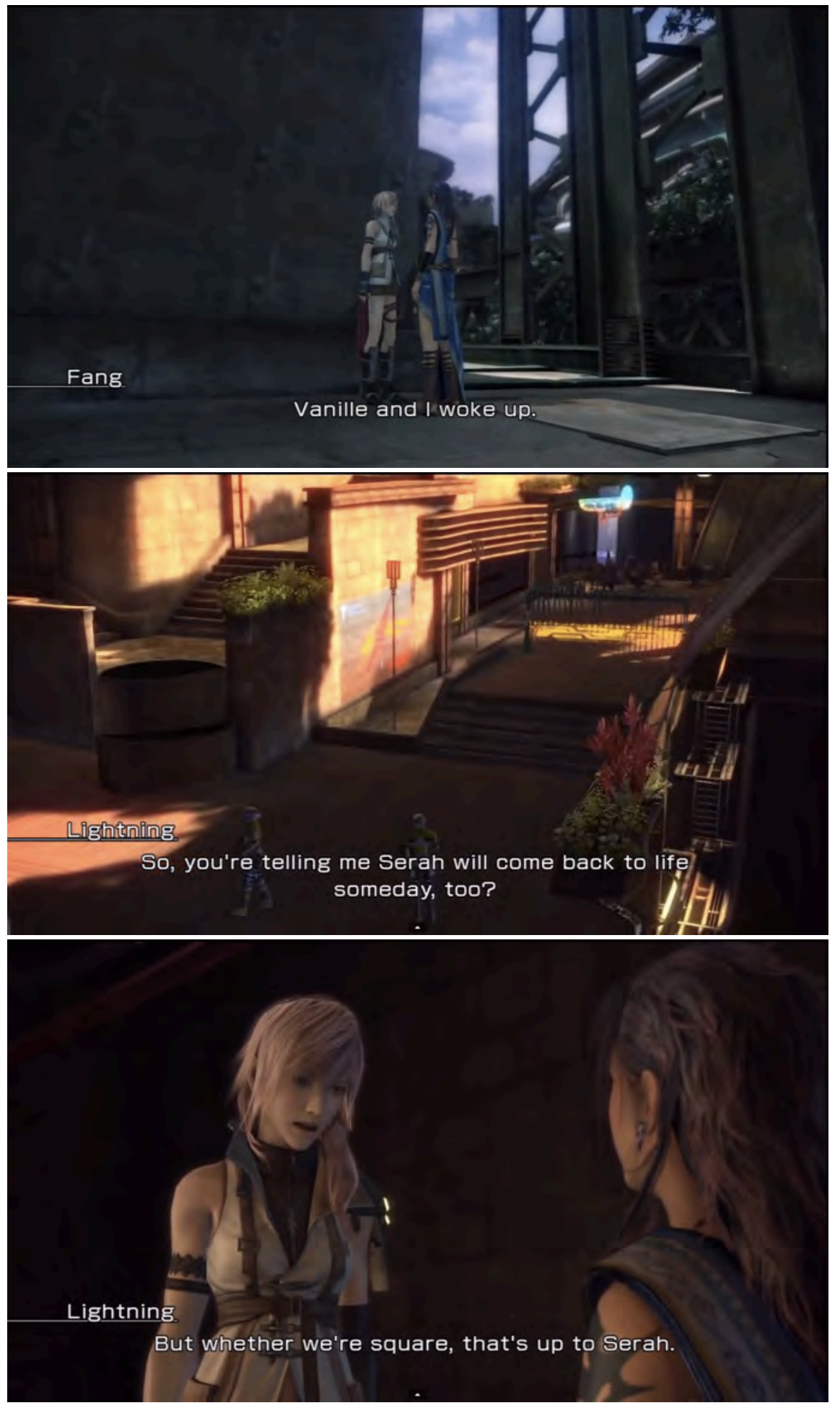

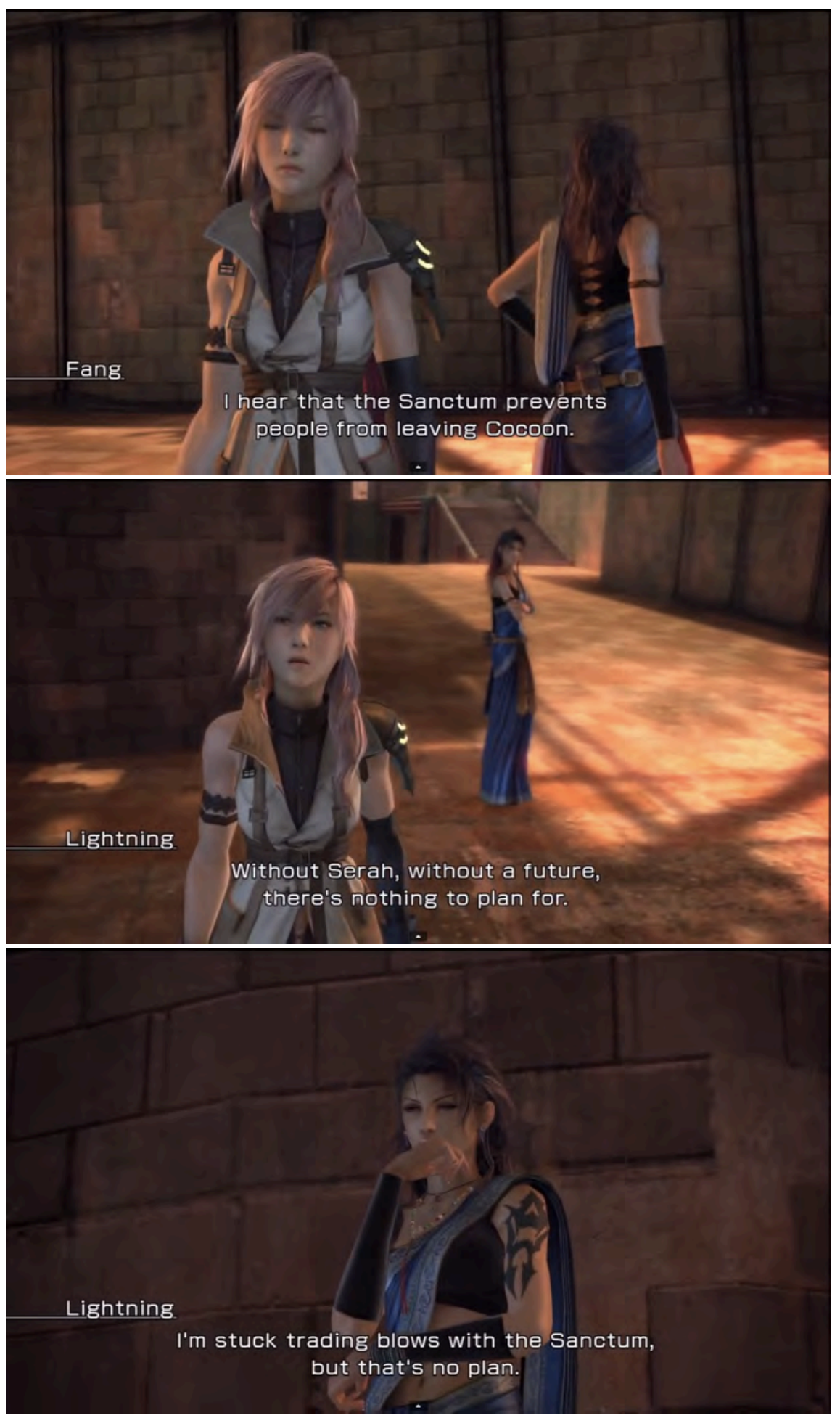

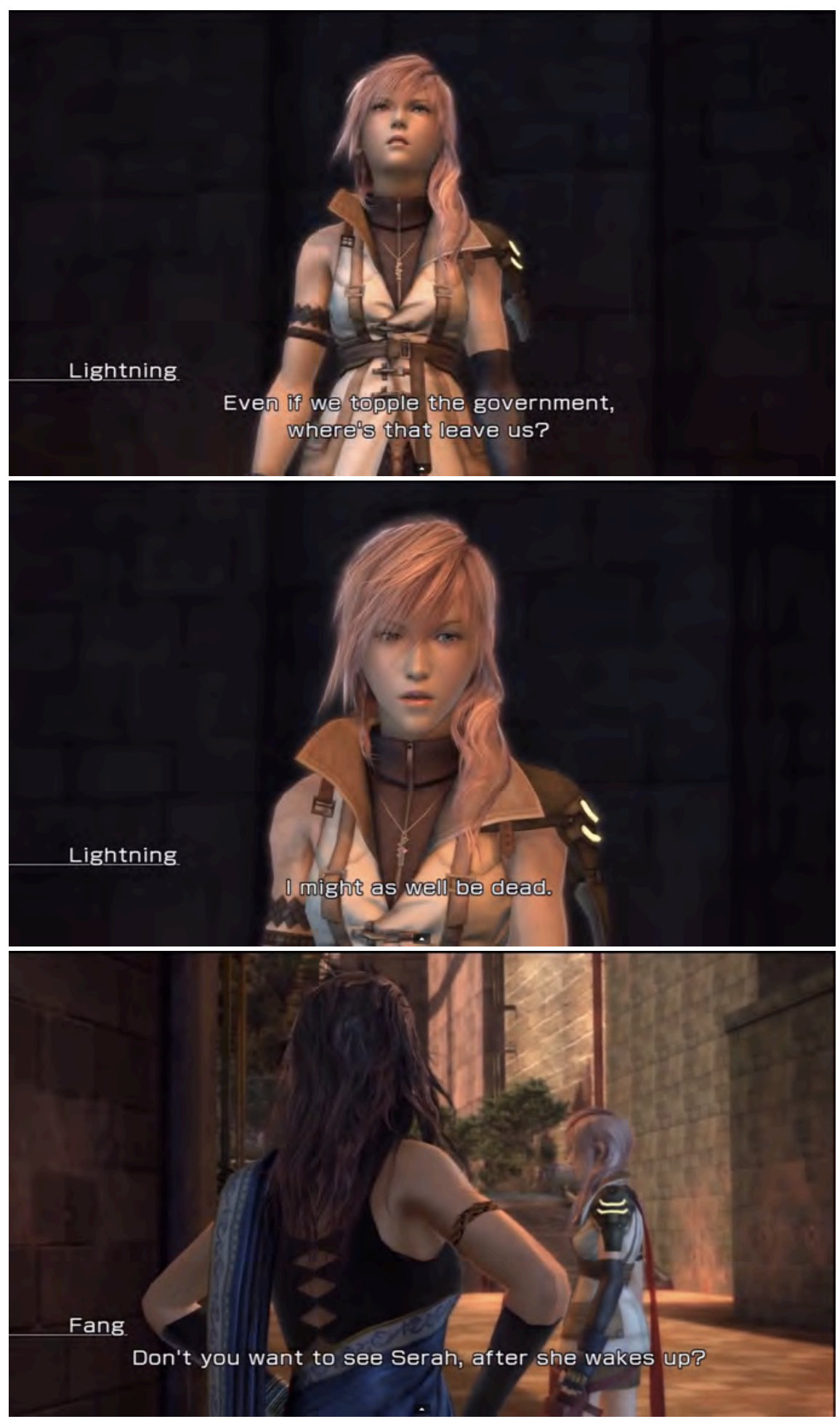

(Figuras 192 a 203: conhecimento por meio da convivência com o outro, admissão da vingança como limitação) 

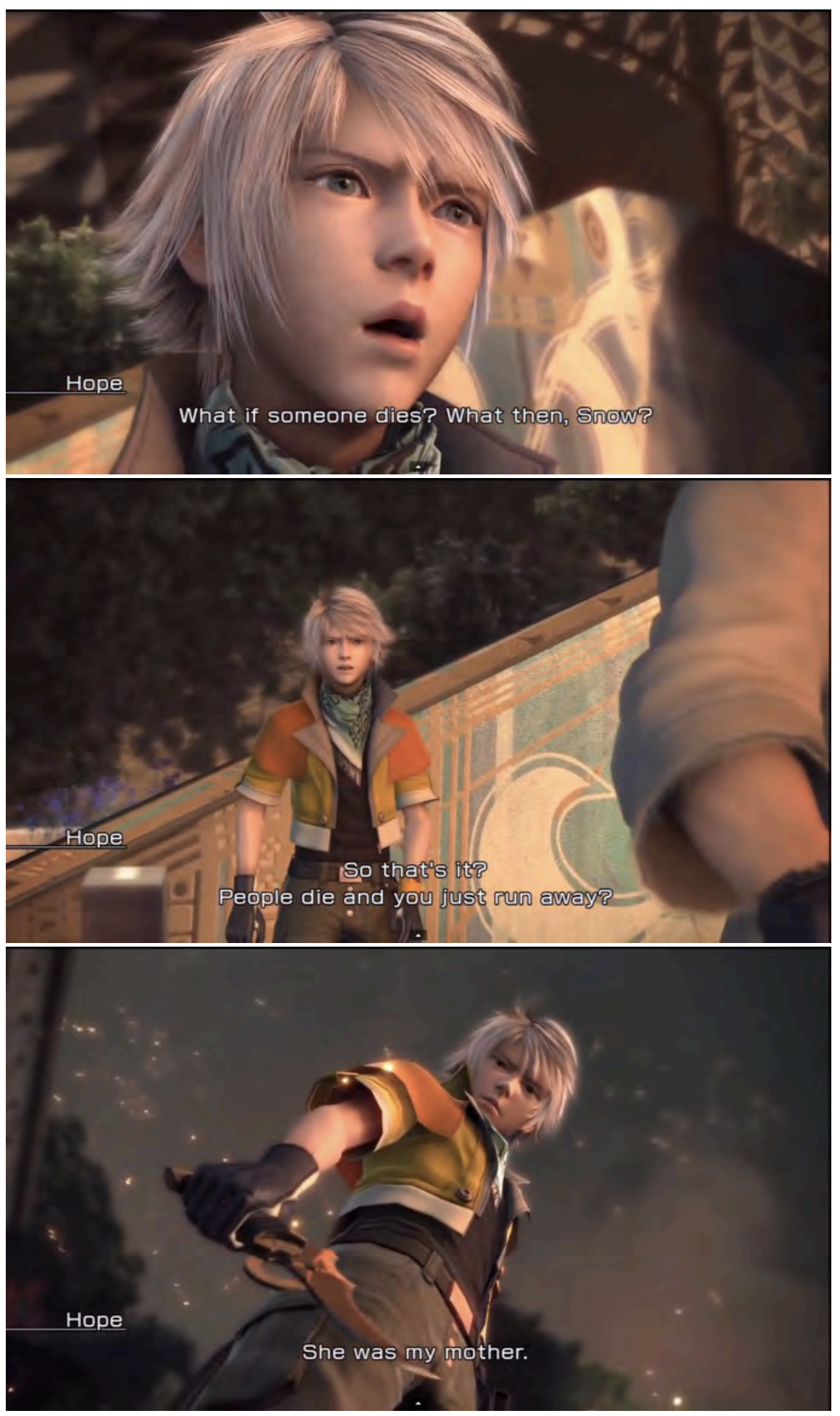


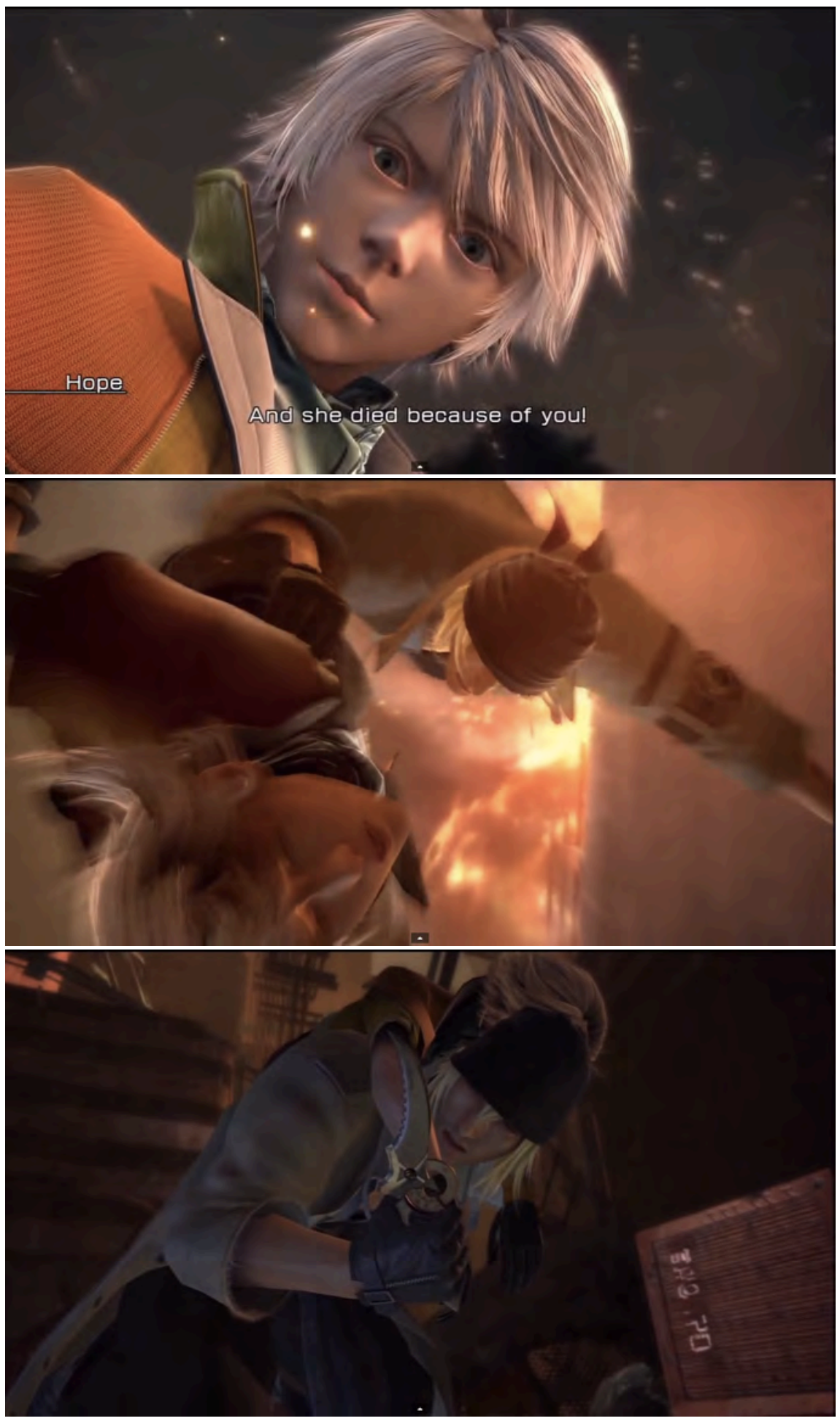



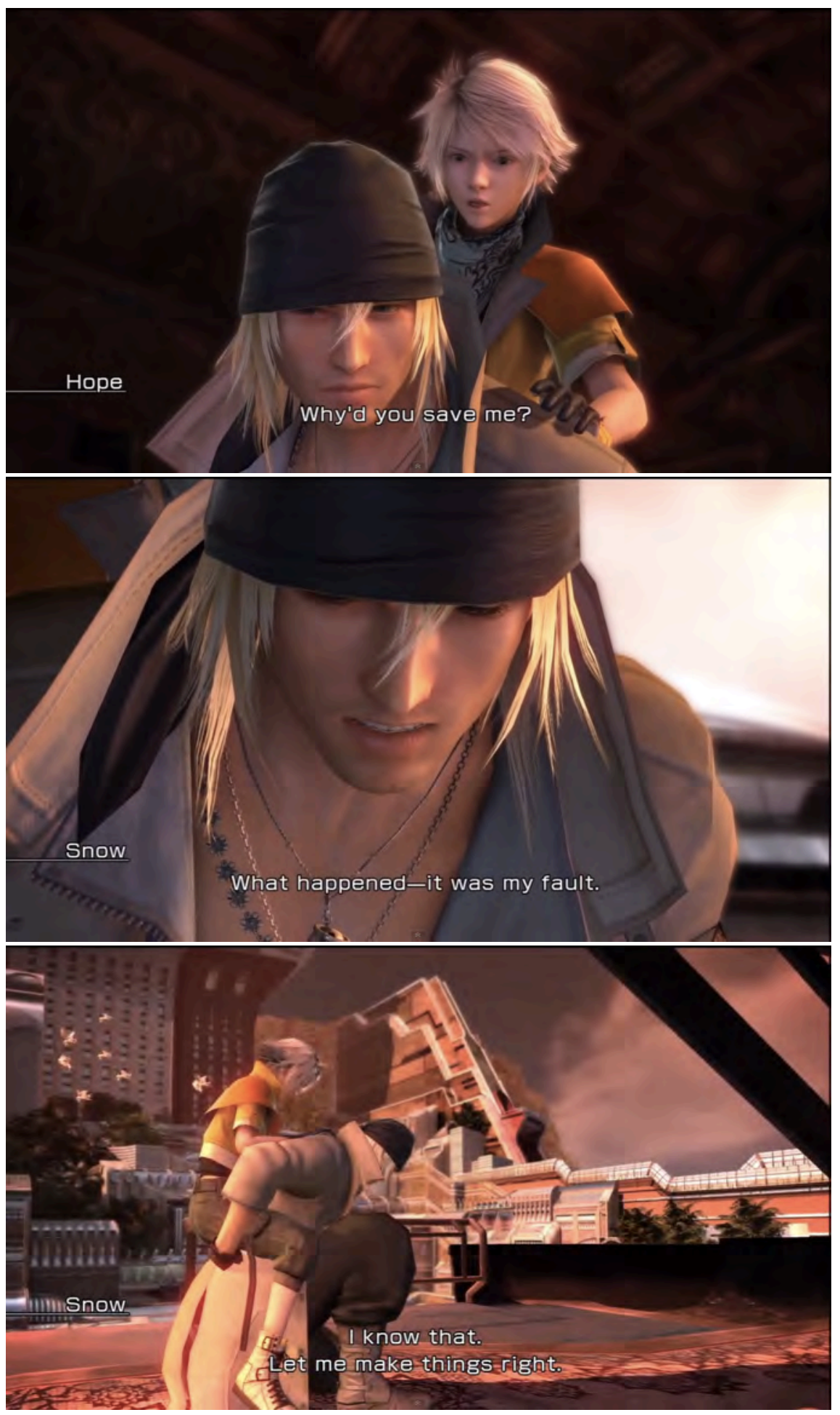


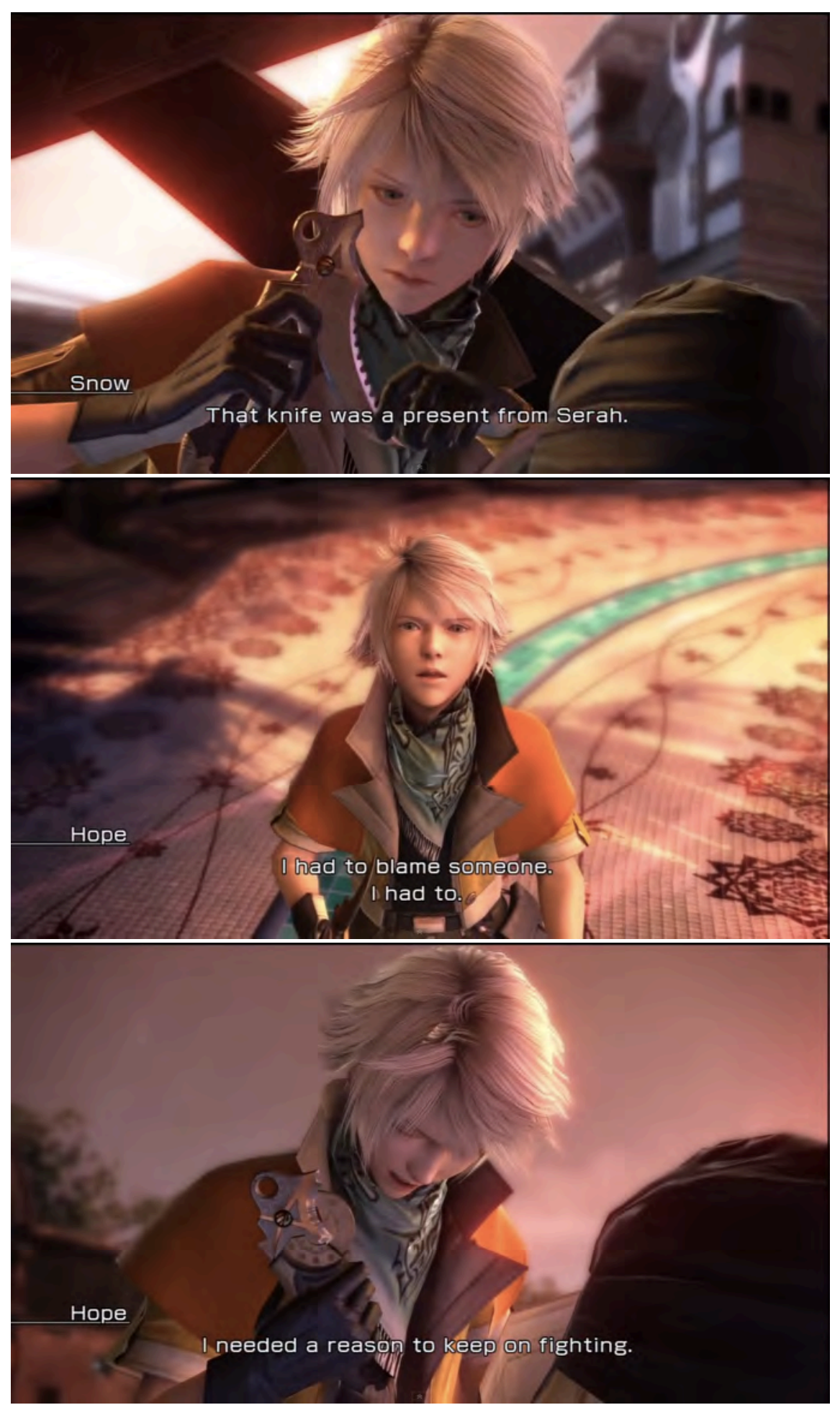

(Figuras 204 a 215: conhecimento por meio da convivência com o outro, admissão da vingança como forma de amenizar a crise identitária)

Como demonstram as imagens acima, a sucessão de eventos na cidade de Palumpolum mostra a Lightning e a Hope que seus conhecimentos acerca de si mesmos e do mundo que os cerca são baseados em um modo de pensar fechado, ensimesmado e que nega totalmente a existência do outro. Sousa Santos (2010), baseando-se no modelo 
colonial de organização do mundo, define como abissais os tipos de epistemologia baseados em distinções

\begin{abstract}
estabelecidas através de linhas radicais que dividem a realidade social em dois universos distintos: o universo "deste lado da linha" e o universo "do outro lado da linha". A divisão é tal que "o outro lado da linha" desaparece enquanto realidade, torna-se inexistente, e é mesmo produzido como inexistente. (p. 32)
\end{abstract}

Essa inexistência impede que haja "copresença entre os dois lados da linha", pois o que é jogado para além do abismo "permanece exterior ao universo que a própria concepção aceite de inclusão considera como sendo o Outro" (p. 32). Em suma, o pensamento abissal parte de uma atitude violenta de desqualificação de um grupo e, consequentemente, de sua cultura e de suas formas de conhecimento. Uma das consequências disso é o enrijecimento dos paradigmas epistemológicos e práticos do lado considerado padrão, os quais são considerados universais - os modos de pensar e os modos de viver de um grupo passam a ser os únicos modos de pensar e viver possíveis dentro da lógica desse mundo. Isso pode ser facilmente relacionado a Ricoeur (2006), sobretudo se pensarmos no apagamento do outro como um atentado não só contra a identidade alheia, mas também contra a própria: apagar as relações de alteridade, ou restringi-las a um grupo pequeno, inviabiliza a formação de um homem capaz, na medida em que sua constituição depende da relação das instâncias idem, ipse e alter. Em contextos diferentes, esse tipo de organização social é nomeado por Sousa Santos como "fascismo do apartheid social" (SOUSA, 2010, p. 45) dentro do que ele chama de "Estado de exceção" (p. 44), um Estado em que os direitos humanos básicos são violados "sob o pretexto da sua salvaguarda ou mesmo expansão" (p. 44). Isso se aplica perfeitamente ao universo ficcional de Final Fantasy XIII, na medida em que a militarização excessiva, a proibição instituicional do contato com qualquer indivíduo ou objeto que venha de Pulse e o medo generalizado de encarar a mera possibilidade de existência do outro como um "eu" servem a um plano maquiavélico de extermínio em massa arquitetado pelos Fal'Cie. Em nossa chave de leitura, o pensamento abissal é uma das condições essencials para que a ideia fixa de vingança domine as personagens. 


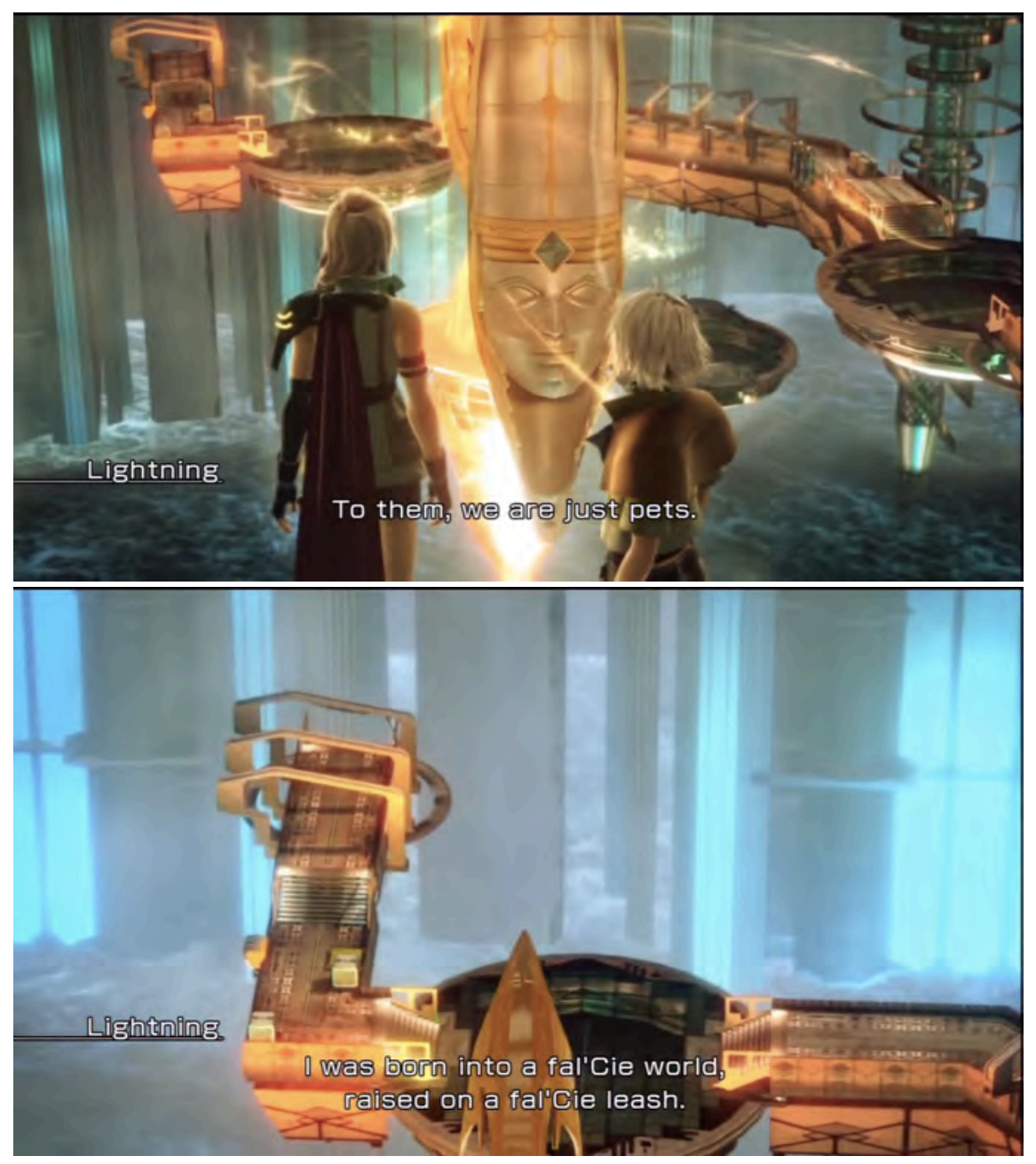

(Figuras 216 a 217: reconhecimento da condição abissal)

A abertura de pensamento marca o final da "crise" patêmica e muda consideravelmente a estrutura do jogo: ao descobrirem, por meio de Vanille e Fang, que o temível mundo inferior de Pulse não passava de uma construção ideológica para mantê-los presos em Cocoon, as personagens decidem visitá-lo para tentar descobrir uma maneira de sair da situação em que se encontram. Fuga, obstinação e vingança cedem lugar ao desejo de auto-conhecimento e de abertura para o outro que são acompanhados pela abertura considerável dos cenários, introdução das missões secundárias e liberdade de composição de grupos e classes para as personagens: 


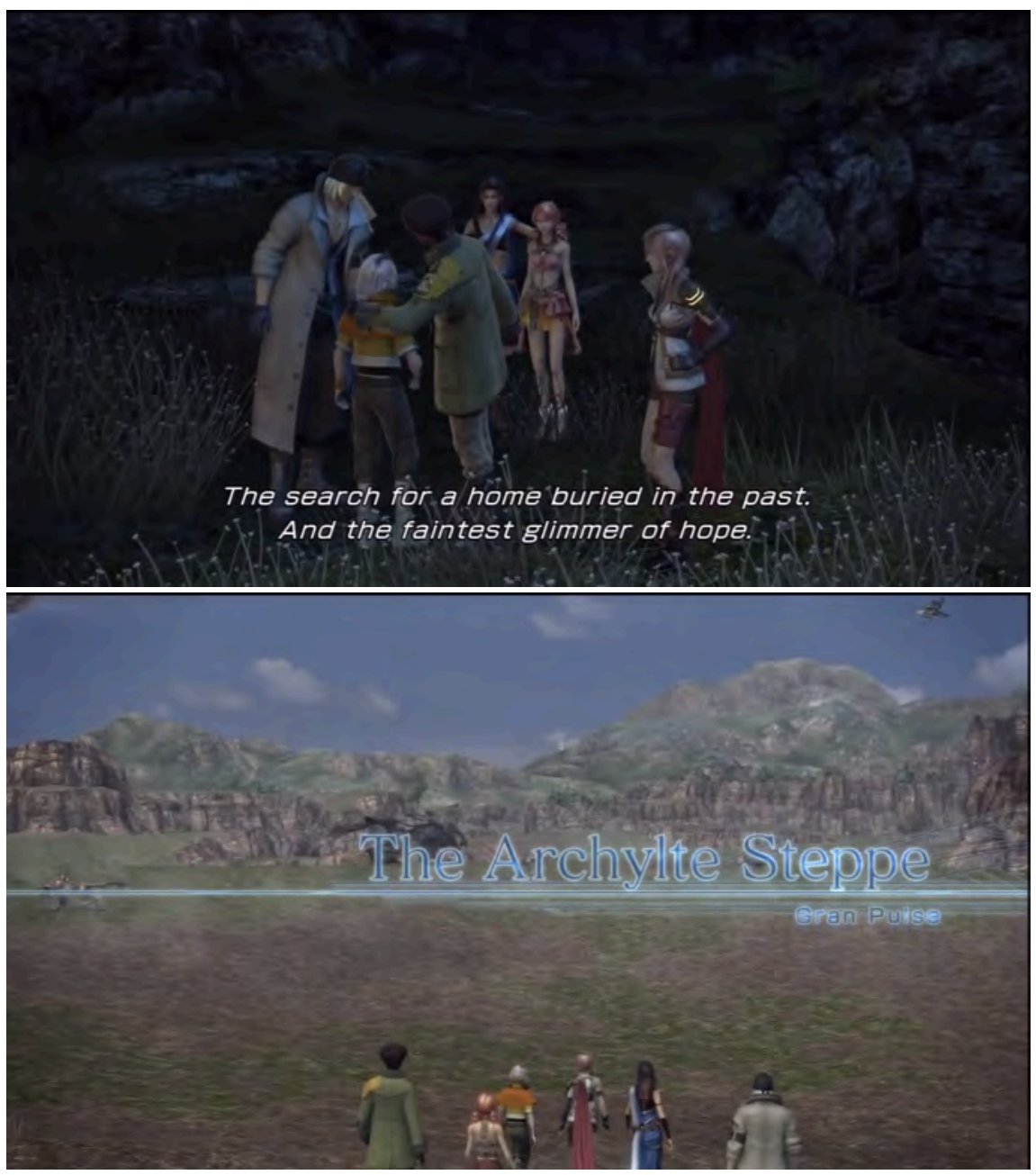

(Figuras 218 e 219: cutscene que marca a transição de estado de jogo, do fechado ao aberto)

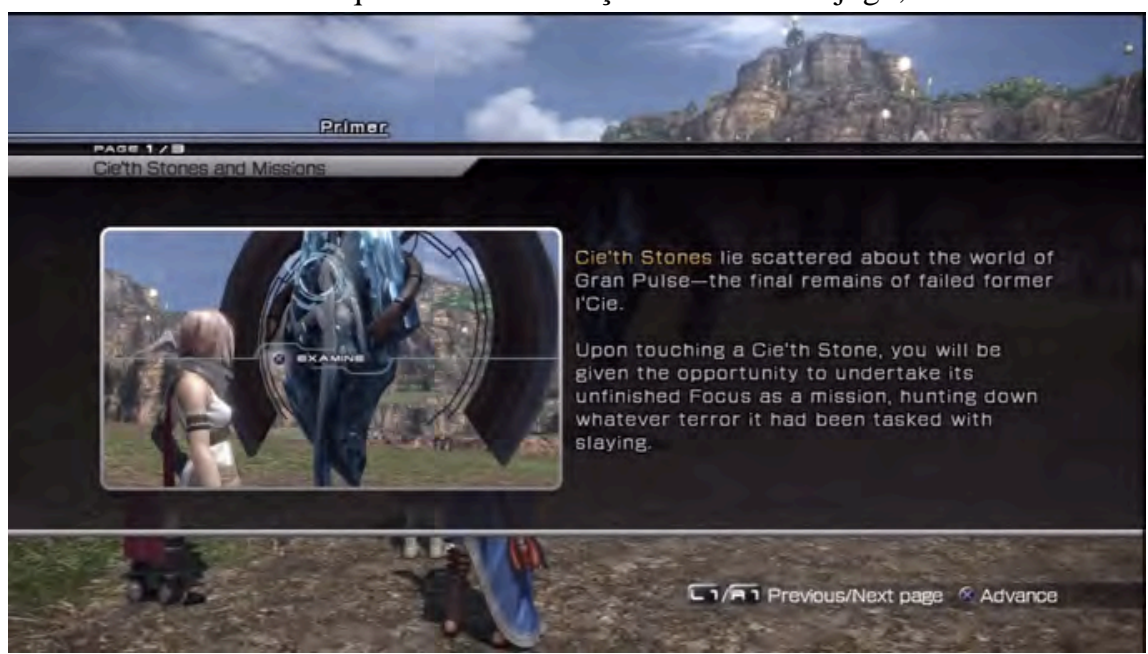

(Figura 220: explicação do sistema de Side Quests) 


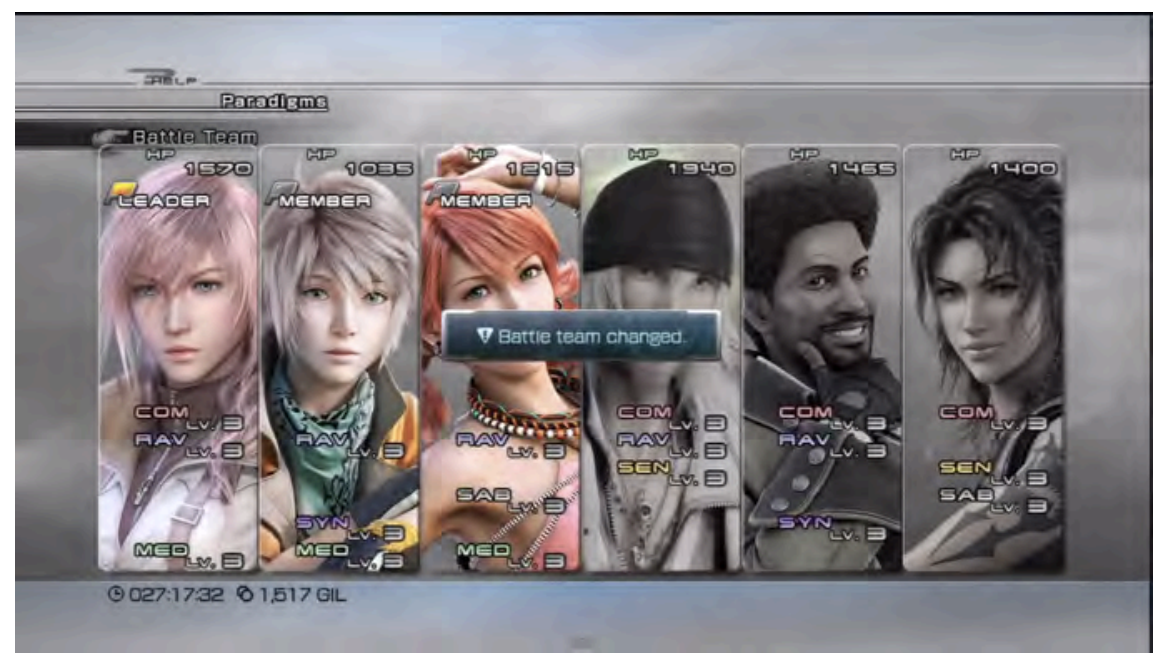

(Figura 221: menu de seleção livre de grupo)

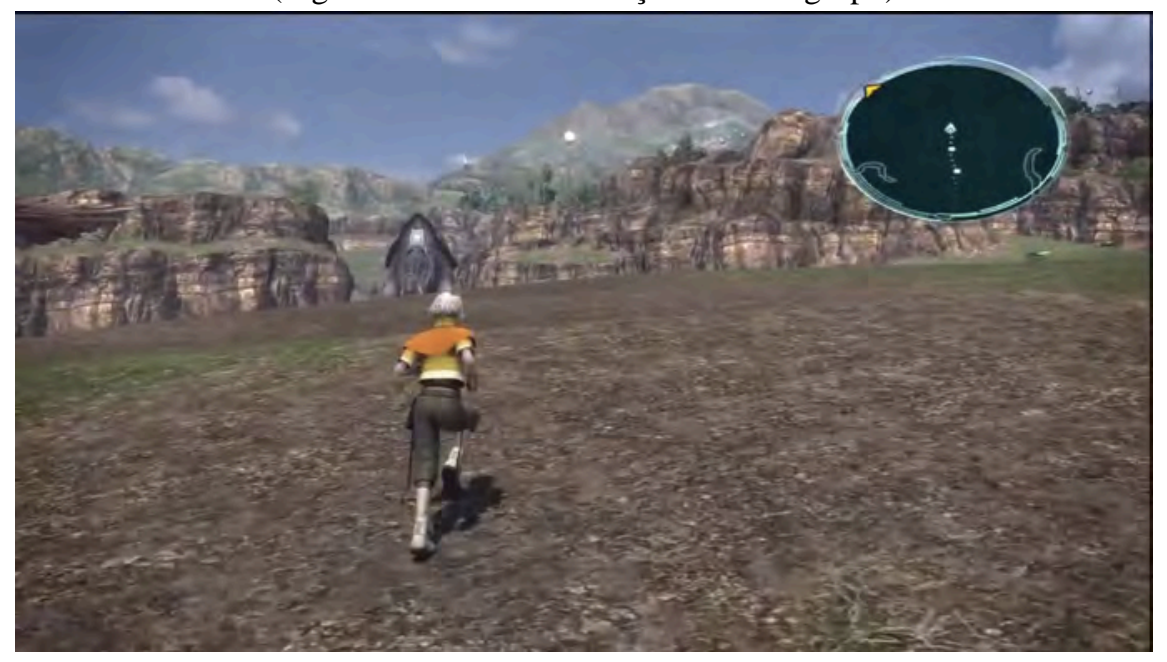

(Figura 222: exploração de cenário alinear)

O mapa que pode ser visto no canto superior direito da imagem acima marca bem a diferença entre os estágios de jogo. Os procedimentos relativos à exploração, às lutas e até mesmo à evolução das personagens (torna-se possível ativar todas as classes em todas as personagens) são alterados de maneira significativa, alterando, assim, as relações valenciais que incidem sobre o corpo do jogador: a vingança, que imprimia uma tonicidade elevada e um andamento acelerado e unidirecional, cede lugar à exaltação da alteridade, que "abaixa a pressão", permitindo maior exploração do espaço e abertura de novos horizontes; no jogo, a progressão pura cede lugar à estrutura de acesso progressivo típica dos RPGs de console. Em suma, a estrutura da vingança, que até então perpassava o jogo todo, é alterada e permite que o jogador, assim como as personagens, explorem novos horizontes (tensivos, inclusive); a experiência como um todo se altera.

Com essa constatação, podemos finalizar nossa análise de Final Fantasy XIII. Embora não tenha sido possível abordar todos os aspectos do jogo com profundidade - tal 
feito seria impossível, dada a natureza deste texto -, nosso objetivo se cumpriu: buscamos demonstrar possibilidade de pareamento entre procedimentos de jogo (plano de expressão) e narratividade (plano de conteúdo); essa relação ocupa em Final Fantasy XIII posição de destaque, mas não lhe é restrita. Em maior ou menor grau, todo jogo produz relações desse tipo, garantindo que o jogador não meramente perceba um sentir alheio, mas sinta ele mesmo as incidências tensivas, partilhando, com personagens ou outros tipos de avatares, uma experiência de corpo que pode abarcar, também ela, conteúdos narrativos complexos como as paixões. Diferentemente do ato enunciativo próprio à literatura ou ao cinema, baseados na exposição, a enunciação envolvida no ato jogar não tem como objetivo mostrar ao seu interlocutário um mundo diferente: é um convite a vivê-lo em sua plenitude. 


\section{Considerações finais}

Finalizado o percurso desta Dissertação, faz-se necessário retomar seus pontoschave para demonstrar sua pertinência. Nossa jornada iniciou-se, no Capítulo 1, com a comparação de pontos de vista diversos acerca dos jogos digitais, e a associação deste trabalho à perspectiva que enfoca seu aspecto discursivo, ou seja, sua condição enquanto linguagem; no Capítulo 2, analisou-se qual a constituição semiótica própria de jogar, garantindo que o objeto não fosse analisado em termos alheios a seus atributos intrínsecos, dentre os quais podemos destacar a estruturação procedural de um conflito. A partir daí, analisaram-se no Capítulo 3 as relações complexas entre essa estrutura e a construção de enredo, determinando como a tradição de jogos transforma um meio expressivo baseado em uma estrutura narrativa simples de conflito em uma mídia de contar histórias. Coube ao Capítulo 4 testar - mesmo que de forma não declarada - algumas das hipóteses desenvolvidas ao longo do texto e apontar a importância de reflexão dedicada à linguagem dos jogos para lidar com a relação complexa entre conteúdo e expressão que neles se desenvolve.

A escolha pelo título "Considerações finais" em vez de "Conclusão" não foi aleatória ou gratuita: apesar de concluído, nosso texto evidentemente não esgota o assunto e não responde a todas as perguntas suscitadas pela pesquisa. Dentre os desenvolvimentos futuros que poderíamos apontar estão os seguintes: 1) o estudo das questões específicas relacionadas à visualidade ludo-digital; 2) a ampliação do escopo dos procedimentos de modo a abarcar os meios materiais de acesso ao jogo (controladores, consoles), indicando que a experiência sensível de jogar em um celular é bastante distinta daquela obtida por meio de um console ou tablet; e 3) o eco das reflexões feitas nesta Dissertação em outros objetos, tais como o teatro (do ponto de vista do fazer teatral, não da contemplação da peça), a improvisação musical, da experiência arquitetônica e demais semióticas cujo centro é a experiência.

Nesse viés, nosso texto assume duas funções: a de expor uma análise e a de provocar outras, talvez mais profundas e acertadas. Se houve sucesso nessa empreitada, cabe ao leitor, nosso destinador-julgador, estabelecer; ao sujeito do percurso da escrita fica 
apenas a certeza da experiência e da conjunção com o objeto-valor estabelecido desde o início: o conhecimento. 


\section{Referências bibliográficas}

ARISTÓTELES. Retórica. Tradução de Manuel Alexandre Júnior, Paulo Farmhouse Alberto e Abel do Nascimento Pena. Lisboa: Imprensa Nacional-Casa da Moeda, 2005. BENJAMIN, W. "A obra de arte na era de sua reprodutibilidade técnica". In: Magia e técnica, arte e política. Obras escolhidas vol. 1. Tradução de Sergio Paulo Rouanet. São Paulo: Brasiliense, 1987, pp. 165-196.

BERTRAND, Denis. Caminhos da Semiótica Literária. Tradução do grupo CASA, sob coordenação de Ivã Carlos Lopes et al. Bauru: EDUSC, 2003.

DUMAS, A. O Conde de Monte Cristo. Tradução de Andre Telles e Rodrigo Lacerda. Rio de Janeiro: Zahar, 2012.

ERNICA, R. R. A incompletude narrativa como efeito de sentido nos jogos digitais. Texto Digital (UFSC), v. 10, p. 46-75, 2014.

ÉSQUILO. The Compleet Greek Tragedies. Editado por David Grene e Richmond Lattimore. Chicago: The University of Chicago Press, 1974, vol. 1.

FONTANILLE, J. Corps et sens. Paris: PUF, 2011.

FREUD, S. "O 'Estranho”". In: Uma criança é espancada, sobre o ensino da psicanálise nas universidades e outros trabalhos. Rio de Janeiro: Imago, 1976, pp. 85-124.

GIDDENS, Anthony. Modernidade e Identidade. Rio de Janeiro: Zahar, 2002, pp. 39-69.

GREIMAS, A. J. Du Sens II. Paris: Éditions du Seuil, 1983.

GREIMAS, A. J.; COURTÉS, J. Dicionário de Semiótica. Tradução de Alceu Dias Lima et al. São Paulo: Contexto, 2012.

GREIMAS, A. J.; FONTANILLE, J. Sémiotique des passions: Des états de choses aux états d'âme. Paris: Seuil, 1991.

HOUAISS. Dicionário Eletrônico da Língua Portuguesa. Instituto Houaiss, 2009.

JUUL, J. Half-Real: Video Games between Real Rules and Fictional Worlds. Cambridge: The MIT Press, 2005. Formato E-Book.

LISPECTOR, C. "Preciosidade". In: Laços de Família: contos. Rio de Janeiro: Record, 1998, pp. 82-93.

MURRAY, J. Hamlet in the Holodeck: The Future of Narrative in Cyberspace. Cambridge: The MIT Press, 1997. 
RANHEL, J. "O Conceito de jogo e os jogos computacionais”. In: SANTAELLA, L.; FEITOZA, M. (orgs.) Mapa do Jogo: A diversidade cultural dos games. São Paulo: Cengage Learning, 2009, pp. 3-22.

RICOEUR, Paul. Percurso do Reconhecimento. Tradução de Nicolás Nyimi Campanário. São Paulo: Edições Loyola, 2006.

SALEN, K.; ZIMMERMAN, E. Rules of Play: Game Design Fundamentals. Cambridge: The MIT Press, 2004. E-Book.

SANTAELLA, L. Navegar no Ciberespaço: O perfil cognitivo do leitor imersivo. São Paulo: Paulus, 2004.

SANTAELlA, L.; FEITOZA, M. "Introdução". In: SANTAELlA, L.; FEITOZA, M. (orgs.) Mapa do Jogo: A diversidade cultural dos games. São Paulo: Cengage Learning, 2009, pp. ix-Xv.

SANTOS, Boaventura de Sousa. "Para além do pensamento abissal: das linhas globais a uma ecologia de saberes”. In: MENESES, Maria Paula; SANTOS, Boaventura de Sousa (Orgs.) Epistemologias do Sul. São Paulo: Cortez, 2010, pp. 31-83.

STALLABRASS, J. Gargantua: Manufactured Mass Culture. New York: Verso, 1996.

ZILBERBERG, C. Elementos de Semiótica Tensiva. Tradução de Ivã Carlos Lopes, Luiz Tatit e Waldir Beividas. São Paulo: Ateliê Editorial, 2011.

ZILBERBERG, C.; FONTANILLE, J. Tensão e Significação. Tradução de Ivã Carlos Lopes, Luiz Tatit e Waldir Beividas. São Paulo: Discurso Editorial: Humanitas, 2001. 
Anexos

Todos os links presentes neste anexo foram verificados em 14/10/2014.

\title{
Anexo A: vídeos em que se pode ver as mecânicas dos jogos analisados
}

\author{
The Magical Quest Starring Mickey Mouse \\ https://www.youtube.com/watch?v=d7g17h-KOxg \\ https://www.youtube.com/watch?v=uY9WbUdWM20
}

\section{Super Metroid}

https://www.youtube.com/watch?v=2mHYOzLh19E

https://www.youtube.com/watch?v=yB317FOcU0Y

\section{Resident Evil}

https://www.youtube.com/watch?v=Aibat_G7hYg (Playstation, Jill, parte 1/4)

https://www.youtube.com/watch?v=PKnSLYDiXXU (Playstation, Jill, parte 2/4)

https://www.youtube.com/watch?v=1Cne-QWBpAU (Playstation, Jill, parte 3/4)

https://www.youtube.com/watch?v=o8hVIo3TRJA (Playstation, Jill, parte 4/4)

https://www.youtube.com/watch?v=Pc7vnJ0O5LU (Playstation, Chris, parte 1/4)

https://www.youtube.com/watch?v=5BDmtOqz4Eo (Playstation, Chris, parte 2/4)

https://www.youtube.com/watch?v=jqyR8NyBclk (Playstation, Chris, parte 3/4)

https://www.youtube.com/watch?v=KvKgEultExc (Playstation, Chris, parte 4/4)

https://www.youtube.com/watch?v=2wzWbkkiDZc\&list=PLEC82144E1F194E6D (Gamecube, Jill, lista de vídeos)

\section{Silent Hill}

https://www.youtube.com/watch?v=4ZviQGOTpZc\&list=PLxg7BuXv6pu4JUQKjiuLxmIaEQuj5nngu (lista de vídeos)

https://www.youtube.com/watch?v=WI5FCJF-Fas\&list=PL1kHzaiuaYHVfAbw5FKdA-sEtg6dNjtjE\#t=0 (lista de vídeos)

\section{Final Fantasy XIII}

https://www.youtube.com/watch?v=idXn7SCr5nw\&list=EL978g4nENgEM (lista de vídeos) 


\section{Anexo B: informações sobre a série Final Fantasy}

http://pt-br.finalfantasy.wikia.com/wiki/Página_principal

http://finalfantasy.wikia.com/wiki/Final_Fantasy_Wiki

http://www.finalfantasyxiv.com

\section{Anexo C: resumo da história dos jogos analisados}

\section{The Magical Quest Starring Mickey Mouse}

Mickey Mouse, Pluto, Goofy and Donald Duck are playing catch in the park. When it is Goofy's turn to throw the ball, he accidentally throws it too far. Pluto runs off chasing the ball and Goofy runs after Pluto, leaving Mickey alone. Mickey goes searching for his friends after a while, but falls down a cliff into a strange magical land. Later, Mickey meets an old wizard who tells Mickey that Pluto was taken by the evil king Pete. Mickey sets out to find his friend and stop Pete's tyranny.

Fonte

http://en.wikipedia.org/wiki/Disney's_Magical_Quest\#The_Magical_Quest_Starring_Mickey_Mouse

\section{Super Metroid}

\section{Prologue}

After Samus completed her mission and eradicated the entire Metroid population on SR388 as commanded by the Galactic Federation (sans the Metroid Hatchling, which she nicknamed "Baby"), she brought the Hatchling to the Ceres Space Colony for research. However, shortly after she left, she received a distress signal from the Station and returned to investigate.

When Samus arrives at the Space Science Academy where the Baby was being studied, she finds all the scientists slaughtered and the containment unit that held the Baby missing. Upon further exploration of the Station, she finds the Baby in a small capsule. As she approaches, Ridley appears and grabs the capsule. After a brief battle, Samus repels Ridley, and he activates a self-destruct sequence to destroy Ceres.

After escaping the explosion, Ridley flees to Zebes, and Samus goes after him.

\section{Zebes}


Samus lands on Zebes, explores the surface, known as Crateria, and heads deeper into the planet. She finds that the old base of Tourian, which was destroyed after Samus defeated Mother Brain during her last visit, has been completely rebuilt, and Space Pirates have resurfaced their activities on Zebes. Samus heads deeper still back into Brinstar to explore, and upon returning, she finds Zebesians all over the rebuilt Tourian base. As Samus moves farther along, she unknowingly finds the entrance to the "new" Tourian, which is blocked by golden statues of Kraid, Ridley, Draygon, and Phantoon, all of which shine with gemstones that only vanish once Samus has defeated the respective bosses in their domains.

Samus sets out to reclaim her original upgrades from Metroid as well as some new ones that help her along her way. Numerous enemies bar her way to find the four guardians. She encounters Kraid, who was one of the guardians of "old" Tourian and has rebuilt his lair, which takes up a large part of Brinstar, and defeats him to claim the Varia Suit as her own. She then makes her way to the Wrecked Ship and finds Phantoon, who has shut off the power supply to the ship, making progress impossible until she defeats him. Afterwards she takes the Gravity Suit from a storage room in the Ship. After making her way through the Wrecked Ship and its mazes, she finds her way into the submerged Space Pirate research facility in Maridia.

After moving through Maridia, Samus find many more upgrades and makes her way to Ridley's Lair in Norfair, where she also finds the Baby's broken capsule. Along the way, Samus encounters the Mochtroids, the products of the Pirates' failed experiment to clone Metroids for use as bioweapons. She annihilates them and continues her quest to make her way into "new" Tourian.

\section{Tourian}

After defeating all the guardians, Samus sets off to return to "new" Tourian's gateway. She enters the facility and finds real Metroids that attack her on sight. After delving deep into Tourian, she annihilates all of the Metroids and nearly reaches the end of the facility when she enters a room and encounters a massive Metroid, much larger than any Metroid she has ever seen. After draining the energy of a few creatures in the room, the Metroid moves in Samus and begins draining her energy.

It was the Baby. By the time it recognizes Samus as its mother, Samus only has one unit of health left. The Baby feels disgraced for attacking its adopted mother and flies off 
shrieking. Samus, barely able to even stand, finds an energy recharge station and reenergizes herself.

She continues on and confronts Mother Brain yet again. She destroys Mother Brain's control unit, and the machine appears to be defeated, but it is revealed to be housed in a separate room and attaches itself to a giant, bipedal mechanical body that it can control freely, offering many more offensive armaments than the previous phase of the fight. After dealing damage to it, Samus is overpowered by Mother Brain's Hyper Beam attack. As Samus in on the verge of death, Mother Brain rears back to deliver the death blow but is stopped by the Baby, who rushes in and absorbs its energy. After apparently depleting Mother Brain's energy, the Baby releases its hold on Mother Brain, and it falls to the floor, gray and lifeless, the same fate of the creatures it attacked earlier in Tourian. The Baby then attaches to Samus, who feared death from her own adopted child, but the Baby did not take the last of Samus' energy. It instead delivered the energy it stole from Mother Brain into Samus' body, completely recharging Samus's energy and endowing additional powers. During this time, Mother Brain miraculously recovers its energy and commences to attack the Baby. After releasing Samus, the Baby rears back for one final attack, intent on destroying Mother Brain, but Mother Brain delivers a deathblow and kills the Baby, destroying the last Metroid specimen and rendering the race extinct.

Samus, whose form is pulsating with the energy given to her by the Baby, knows she possesses the power to defeat Mother Brain. A fierce, final battle ensues, and Samus easily defeats Mother Brain using the Hyper Beam, destroying her once and for all.

After exploding, a countdown begins that results in Tourian exploding. Racing for her life, Samus runs through hidden passages in Tourian and Crateria. Along the way, she rescues three Etecoons and a Dachora that she met in Brinstar as she makes her way back to her Gunship. As she leaves Zebes, home of the Chozo and the place where Samus was raised until she was mature enough to venture off on her own, the planet explodes with violent force and nothing is left behind.

In Metroid: Other M, which immediately follows the events of Super Metroid, Samus experiences a sense of longing for the Baby, and she is reminded of it often, particularly after receiving the "Baby's Cry" distress signal from the Bottle Ship. DNA from her Power Suit is later used to clone Metroids (including a Queen Metroid) and Ridley.

\section{Fonte}

http://www.metroidwiki.org/wiki/Super_Metroid\#Plot 


\section{Resident Evil}

O primeiro jogo da série se inicia na noite de 24 de julho de 1998, onde nas Montanhas Arklay, houve uma série de assassinatos beirando o canibalismo. Para investigar estes assassinatos foi enviado um grupo dos S.T.A.R.S., a unidade tática da cidade de Raccoon City. Porém, assim que o time Bravo começa a sobrevovar as florestas de Arklay, eles perdem contato com a base policial. Para localizar o Bravo Team, foi enviado o Alpha Team. Ao pousarem perto de uma mansão desconhecida, um integrante de equipe, Joseph Frost, encontra uma mão decepada, e logo é atacado por cães, que o matam. Ao tentarem correr para o helicóptero, o piloto, Brad Vickers, desesperado, foge deixando o resto da equipe cercado. Eles conseguem correr para dentro da mansão. Com os cães vagando no lado de fora, os quatro membros restantes do Alpha (Chris Redfield, Jill Valentine, Barry Burton e Albert Wesker) se vêem presos lá dentro. Neste ponto, o jogador assume o controle do personagem e começa sua jornada pela sobrevivência. Uma das primeiras descobertas é um membro do Bravo, Kenneth J. Sullivan, sendo comido por um zumbi (em RE Remake encontra-se uma fita de vídeo que mostra Kenneth morrendo). O personagem eventualmente imagina que a mansão esteja abandonada, cheia de enigmas e armadilhas. Documentos e arquivos espalhados pela casa sugerem que uma série de experimentos e atividades criminosas estavam sendo realizadas na propriedade, sob a autoridade do conglomerado farmacêutico Umbrella Corporation. As criaturas vagando dentro e fora da mansão são os resultados dessas experiências, que têm exposto seres humanos, animais e insetos a um altamente contagioso e mutagênico agente biológico conhecido como o "TVírus". Depois de adentrar em uma série de túneis e salas, o jogador descobre um laboratório subterrâneo contendo detalhadamente os experimentos da Umbrella. No laboratório, Albert Wesker (capitão do Alpha Team) revela ser um agente da Umbrella e liberta o Tyrant T-002, uma criatura humanóide criada por meio da exposição prolongada ao T-Vírus. Tyrant vai em direção de Wesker e o ataca, aparentemente, matando-o. Após o "assassinato" de Wesker, um programa de autodestruição é acionado. Tyrant encontra os S.T.A.R.S., que respondem à tiros. O jogador pede resgate ao helicóptero. Resistindo aos disparos feito pelos S.T.A.R.S., Tyrant é finalmente morto quando o piloto, Brad Vickers, joga um lança-foguete para o jogador. Os S.T.A.R.S. escapam e logo em seguida a mansão explode.

\section{Fonte}

http://pt.wikipedia.org/wiki/Resident_Evil_(jogo_eletrônico)\#Hist.C3.B3ria 


\section{Silent Hill}

Sete anos atrás Harry Mason e sua esposa encontraram um bebê numa estrada e o adotaram como se fosse sua filha, eles deram o nome de Cheryl a ela. Mesmo depois que sua esposa faleceu, Harry continuou a amar Cheryl como sua própria filha.

No começo do jogo, nós encontramos Harry Mason e Cheryl, de férias, indo para Silent Hill. Estranhos eventos ocorrem antes que eles entrem na cidade. Uma policial, numa moto, passa à frente deles. Momentos depois, Harry vê a moto caída na beira da estrada e a policial não está em parte alguma. Logo depois, uma figura de uma garota subitamente aparece na estrada. Harry tenta desviar,derrapa o carro e desmaia.Quando retorna a consciência, Harry descobre que Cheryl se perdeu e ele se percebe no meio de um mal que devagar envolve Silent Hill, sem saber que a única maneira de sair dali é pelo sacrifício da própria filha.

A cidade de Silent Hill é dividida em três partes distintas: a Silent Hill normal, a Silent Hill escura e a Silent Hill alternativa. As leis da física parecem não existir na realidade alternativa, na qual a cidade mergulha de vez em quando. O chão é feito de grade sem nenhum tipo de sustentação visível (como se a cidade flutuasse, talvez para mostrar que aquela realidade não é física nem real), portas levam a lugares distantes (às vezes, separados até mesmo por quilômetros), mesmo sem energia elétrica, aparente, TVs e sons se ligam quando bem entendem e a lanterna e o rádio de Harry, apesar de portáteis, não conseguem acabar com as baterias.

Em Silent Hill, a personagem Alessa Gillespie e sua mãe Dahlia Gillespie são mostradas juntamente com outros personagens, tentando reviver o antigo culto da cidade. Dahlia tenta queimar sua filha, que tem poderes psíquicos e é chamada de bruxa no colégio, dentro de casa em sacrifício ao antigo deus do culto, Samael. Com quase $100 \%$ do corpo queimado e dominada por ódio, Alessa é levada ao Hospital Alchemilla, onde é colocada em um quarto obscuro de uma ala subterrânea para ser "tratada" e oferecida novamente em sacrifício. Mas, com seus poderes, Alessa divide sua alma em dois. Uma metade fica no hospital, dormente, sofrendo e tendo pesadelos constantes, e a outra metade é entregue nas mãos de Harry Mason e sua esposa.

Sua enfermeira pessoal, Lisa Garland, diz em um registro em video que não entende como o corpo de Alessa consegue se manter vivo com tantas queimaduras. Esta por outro lado, tem sua memória afetada durante a época de cuidado intensivo de Alessa por terem lhe 
sido administradas drogas pelo diretor do hospital, Dr. Michael Kauffman, que tem uma ligação de benefícios com Dahlia Gillespie.

Quando Cheryl é levada a cidade de Silent Hill, já com sete anos de idade, estranhos acontecimentos ocorrem. Alessa, já com 14 anos, acorda e sai do hospital para encontrar a sua metade. Isso ocorre quando Harry entra em um beco e é atacado por pequenos monstros chamados "Mumblers". Perdendo a consciência, ele é encontrado por Cybil Benett, a policial que ultrapassou o carro de Harry no início do jogo. Ai se inicia uma busca por sua filha perdida, que não tendo sucumbido totalmente a vontade de Alessa, deixa bilhetes para o pai, para que ele consiga seguí-la.

O Flauros é um objeto que pode acabar com os poderes de Alessa, assim como o Aglaophotis, que é apenas uma mistura de ervas sem valor no mundo real, mas que Alessa acredita ser fatal (juntamente com o Flauros, que ela acredita trazer os poderes de Metraton) e sendo criadora do submundo (devido aos pesadelos constantes que viveu durante tantos anos e que agora foram externados com a ajuda da sua outra metade), estas ervas e o Flauros são realmente fatais para os monstros.

\section{Fonte}

http://pt.wikipedia.org/wiki/Silent_Hill_(jogo_eletrônico)\#Hist.C3.B3ria

Silent Hill is set in the year 1983. Harry Mason, an ordinary father, is taking his adopted daughter, Cheryl, to a vacation in the resort area of Silent Hill, a small American town known for its very peaceful ambiance. While driving on the outskirts of the town, Harry sees a girl walking across the road. Harry swerves his car to avoid hitting her and is knocked unconscious by the resulting car crash. Harry wakes up later to find that Cheryl has disappeared, and is forced to venture into the snowing fog-covered town to rescue her. Harry leaves the area to look around, and sees Cheryl running away and immediately hurries to follow her. Chasing her through the streets of Silent Hill, he finds himself running down a small residential street and into a dark alley. The sky suddenly turns dark, a siren blares in the distance, and when Harry lights the area with a lighter, he finds that his entire environment has changed into the Otherworld. The road pavement has been replaced by rusted metal grating and platforms, and the walls are a dark, grimy series of mesh and chain link fences. Everything is covered in rust and blood, tipped with barbed wire, and the shapes of hanging bodies are discernible behind the mesh. The sounds of industrial clanking and grinding metal form a constant cacophony of ambient noise. With nowhere to 
go, Harry follows the alley and finds the disturbing body of a mutilated corpse hanging on a fence before him. Moments later, he is attacked by small, child-like monsters. Despite his best efforts, Harry is eventually overwhelmed and "killed".

He wakes up in a deserted diner called Cafe 5to2. An officer named Cybil Bennett appears and after a brief conversation, she provides him with a handgun and leaves to look for help. In the diner, Harry arms himself with a map, a knife and a flashlight. As Harry attempts to leave the diner, a radio on a nearby table starts emitting static, causing Harry to investigate it. A flying monster crashes through a window and into the store and assaults Harry. Harry defeats the monster with his handgun and stands there in disbelief for a moment before leaving the diner. Harry soon encounters other monsters on the foggy streets. He quickly discovers the radio's usefulness when it emits intensifying static as monsters grow closer. Following a clue left by his daughter, Harry eventually finds his way to Midwich Elementary School to search for her.

From his initial inspection, the school itself is long since abandoned. Instead of students and teachers, Harry finds many Grey Children/Mumblers. Harry works his way around, eventually unlocking the clock tower in the school's courtyard. Upon reaching the other side of the facility across the courtyard, he is shocked to find the world has once again shifted into the Otherworld. Again, the already dwindling light is reduced to nothing more than what Harry's flashlight can produce, and the surfaces have all undergone a horrific shift back to the metal grating and uneven platforms. In the Otherworld school, Harry travels to the boiler room. Inside, light is cast by a flaming corpse, illuminating a creature known as Split Head - a large lizard with its head split in half. With its defeat, everything turns to darkness, and then the light returns to reveal an ordinary boiler room. A girl, Alessa Gillespie, is leaning against the boiler. She turns to Harry and disappears into thin air.

Confused, Harry leaves the school. He hears a church bell ringing in the distance and heads to the Balkan Church, where he sees an old woman praying at an altar. She turns to meet Harry, and in a conversation that he has difficulty understanding, the old woman reveals herself to be Dahlia Gillespie. She gives Harry a mystical item called the Flauros and tells him to make haste to the hospital. Before Harry can ask any questions, Dahlia leaves and Harry exits the church. He crosses a bridge that leads to Central Silent Hill.

Harry arrives at Alchemilla Hospital, where he encounters Michael Kaufmann, a doctor who is as bewildered as Harry about the current circumstances. Shortly after this meeting, 
Harry endures another shift to the Otherworld, transforming the medical facility into the Otherworld's twisted version of the hospital, infested with monstrous nurses. Along the way he also meets Lisa Garland, a terrified nurse. Though she knows much about the town and its history, he is unable to get answers before he is transported back to the fog world, where Dahlia reappears and tells him that the "Mark of Samael", a strange symbol he has seen in various locations, must not be completed, lest the darkness devour the whole town. Meeting up with Cybil, who has seen a girl out on the lake, the pair find a hidden altar in an antiques store, but Harry disappears out of sight of Cybil, much to her confusion. Harry, meanwhile, finds himself back in the hospital with Lisa, who gives him directions to the lake, but also tells Harry she feels she's "not supposed to leave".

On the way to the lake, Harry crosses a waterway and enters the resort area. The player may determine Kaufmann's fate (and the game's ending) by choosing to assist him in Annie's Bar. Soon after, the Otherworld nightmare begins to take over the town completely. Regrouping with Cybil, and deciding to stop the mark's completion at Dahlia's desperate request, Harry heads to the lighthouse and Cybil heads to Lakeside Amusement Park. As a cutscene shows Cybil attacked by an unknown assailant, Harry once more sees Alessa, and the symbol, at the top of the lighthouse, before heading to the amusement park himself. On the amusement park's carousel, Cybil appears, possessed by a parasite. The player may choose to save or kill Cybil, once again affecting the game's ending. With Alessa appearing once more, Harry unwittingly uses the Flauros to trap her. Dahlia appears, revealing that she manipulated him into trapping her, as he was the only one who would be able to get close to her, and that Alessa is in fact her daughter.

With Alessa's powers out of control, Harry awakens to find himself back in the distorted world resembling the hospital, simply known as "Nowhere". He finds Lisa, who has come to realize that she is no different from the other nurses. She begins to transform in front of a horrified Harry, who flees when she approaches him, though he is clearly sympathetic. Lisa's diary, left in the room, explains that she was the nurse who attended to Alessa in return for a drug she was addicted to, PTV, which Kaufmann supplied. In Nowhere, Harry sees a flashback of a meeting between Dahlia, Kaufmann and two cult doctors discussing Alessa's hospitalization and the rebirth of God.

Harry soon finds Dahlia and Kaufmann (and Cybil, if he saved her earlier), as well as a figure in a wheelchair wrapped in bandages: Cheryl/Alessa recombined, with Alessa's astral projection sitting nearby. Both the flashback and Dahlia's words explain that Dahlia 
sacrificed her daughter to fire seven years ago in an attempt to nurture and bring about the birth of the God worshiped by a fanatical cult of which Dahlia is a priestess, and that the God now resides within Alessa's womb. In doing so, Alessa's soul was split in two by hatred, and the God could not be born. The other half of the soul manifested itself as Cheryl, whom Harry and his wife found as a baby on the road outside of Silent Hill and subsequently adopted. In the present, Alessa, having called Cheryl back to the town so that she could complete the Seal of Metatron and kill herself, manifested herself in the town to place the marks Harry has seen in an attempt to keep the God at bay. With Alessa's plan defeated and the two halves of her soul now back together, the God creature begins to manifest itself. Kaufmann appears and throws a vial of Aglaophotis at the God. Depending on the actions of the player, the God appears as either Incubus or Incubator. Both forms kill Dahlia instantly, before turning its attention to Harry, who ultimately defeats it. Endings

- Good+ (Complete the Kaufmann sidequest and save Cybil): Cybil tries to shoot Dahlia, but fails and Alessa and Cheryl merge, becoming the Incubator. Kaufmann then appears, shooting Dahlia and throwing the Aglaophotis at the Incubator. When hit with the liquid, the Incubator falls to the ground, screaming as the Incubus emerges from her back. The Incubus kills Dahlia. Harry then fights and defeats the Incubus, and the Incubator gives him a baby (who is revealed to be Heather Mason in Silent Hill 3) and shows him the escape route. Harry, Cybil and Kaufmann try to escape, but a blood-covered Lisa Garland appears and drags Kaufmann with her into the abyss. Harry and Cybil continue their escape; however, the Otherworld is collapsing too quickly for them to make it on their own, so the Incubator uses the last of her power to stop the world's destruction in order for them to escape. The Incubator is then consumed by the flames and Cybil and Harry escape together with the baby.

- Good (Complete the Kaufmann sidequest and kill Cybil): Alessa and Cheryl merge, becoming the Incubator, but Kaufmann appears, shooting Dahlia and throwing the Aglaophotis at the Incubator. When hit with the liquid, the Incubator falls screaming to the ground as the Incubus emerges from her back. The Incubus kills Dahlia. Harry defeats the Incubus and the Incubator gives him a baby and shows him the escape route. As Harry escapes, Kaufmann tries to follow him but is stopped by Lisa. The Incubator is consumed by the flames. Harry safely makes it to 
the highway on the outskirts of the town and stares up at the sky, bewildered at everything that has happened. The Book of Lost Memories states that this is the "orthodox ending" connected to the third game.

- Bad+ (Don't complete the Kaufmann sidequest and save Cybil): Alessa and Cheryl merge, becoming the Incubator, and kill Dahlia. Cybil then appears and tries to kill Dahlia, but fails. Harry then battles Incubator who, after defeat, thanks Harry. Harry then collapses in sorrow over the loss of his daughter. Cybil walks over to Harry, smacks him out of his grief, and tells him to go as the Otherworld collapses around them.

- Bad (Don't complete the Kaufmann sidequest and kill Cybil): Alessa and Cheryl merge, becoming the Incubator, and kill Dahlia. Harry then battles the Incubator who, after defeat, thanks Harry and says goodbye. Harry collapses in sorrow over the loss of his daughter. Harry is then seen bleeding from his head, unconscious in his car, which suggests that everything that happened in Silent Hill was just a dying dream. This ending is ironic because at one point in the game, Harry foreshadows this by wondering whether everything that is happening to him is just a dream that he is having in a hospital after a car accident.

- UFO: When Harry uses the Channeling Stone for the fifth time on top of the lighthouse, a group of UFOs is seen in the sky. As the UFOs land, the cutscene changes style to a roughly animated picture show. Harry tries to ask the aliens if they have seen his daughter, but is shot down and brought into their spaceship. The UFOs take off and the credits roll in a fashion similar to the 3D billing effect commonly used for horror/supernatural projects in the early/mid 1900s.

Fonte

http://silenthill.wikia.com/wiki/Silent_Hill_(video_game)\#Plot 


\section{Anexo D: resumo de Final Fantasy XIII}

\section{Fates Intertwined}

Having been secluded from the outside world for so long, the citizens of Cocoon have become paranoid of Gran Pulse. The Sanctum, Cocoon's government, led by the fal'Cie Eden and Primarch Galenth Dysley, issues an edict whereupon any individuals suspected to have come in contact with anyone or anything from the lowerworld of Pulse are to be banished from Cocoon.

One day, there is an incident at the Euride Gorge Energy Plant believed to have been caused by Pulse l'Cie. Six days later, a Pulse fal'Cie is discovered in the seaside town of Bodhum. Mass panic breaks out and soon Cocoon's citizens are crying out for the expulsion of the entire town to Pulse, prompting the Sanctum to initiate the Purge. Within the next two days the Sanctum's personal army, PSICOM, quarantines Bodhum, seizes the town's inhabitants regardless of whether they are citizens or tourists, and forces them onto Purge trains. The people are taken to the restricted Hanging Edge zone, along with the Pulse fal'Cie, Anima, contained within the Pulse Vestige.

One of the many onboard a Purge train is Lightning, a former Guardian Corps soldier who seeks to reach Anima and save her sister, Serah Farron, who ten days prior had become a Pulse l'Cie and is now being held captive by Anima. Accompanying her is Sazh Katzroy, a civilian airship pilot with a secret reason for pursuing the fal'Cie. They stop the train and fight their way through the Hanging Edge as the Purge's true nature is revealed: instead of a forced migration to Pulse as the Sanctum had everyone believe, it is a genocide. Elsewhere, Snow Villiers and his friends in NORA rally the deportees in a rebellion against PSICOM as he is also trying to rescue Serah, as she is his fiancée. Two children caught up in the chaos, Hope Estheim and Vanille, become involved when Hope's mother, Nora Estheim, joins Snow's resistance army and dies under his care, prompting the two to pursue him.

The five come together in the Pulse Vestige where they find Serah. She urges Lightning to save Cocoon before entering crystal stasis, a crystal sleep a l'Cie enters upon fulfilling their Focus. Lightning believes Serah is dead, while Snow refuses to give up the hope she will awaken someday. Seeking vengeance on Anima, Lightning heads into Anima's Throne to destroy the fal'Cie responsible for Serah's fate. 
As the party faces Anima, PSICOM forces blast the Pulse Vestige and everything in it to pieces. The party is transported into an otherworldly realm where the god Pulse transforms Lightning and her companions into l'Cie, showing them a dreamlike vision of their Focus involving the capital city of Eden and Ragnarok. They fall down towards Lake Bresha below but survive due to Anima crystallizing the area in its death throes.

\section{Separate Paths}

Now enemies of the state, the newly branded l'Cie assume their Focus is to destroy Cocoon although Snow believes it to be Serah's wish to save it. They set off to escape the lake and come across Serah's crystallized form that has become part of the crystallized lake. Snow insists on staying by Serah's side while the others seek to outrun pursuit as PSICOM is hunting them and other Purge survivors. The party splits with Snow staying to dig out Serah, while Lightning and rest head to the ruins of an old city at the lake's edge where they come across an airship left by a PSICOM patrol.

After nearly being killed by a PSICOM platoon sent to exterminate him, the Shiva Sisters manifest in front of him and after subduing them Snow receives his Eidolon. He is captured along with Serah's crystal by another Pulse l'Cie, Oerba Yun Fang, as well as Rygdea and other members of the Cavalry, a division of the Guardian Corps.

Sazh pilots the stolen airship through the blockade and while onboard the group views a live newscast interviewing Galenth Dysley about the ongoing operation being carried out by PSICOM after the 'success' of the Purge. The airship is shot down by PSICOM pursuit and crashes in the Vile Peaks. The party splits after a disagreement on their Focus: Sazh and Vanille wish to flee from their pursuers, but Lightning is intent on getting revenge by destroying the Sanctum and the fal'Cie Eden said to be in control of it. Accompanied by Hope, she intends to travel through the Gapra Whitewood, his hometown of Palumpolum, and take a train to Eden, the heart of the Sanctum government.

As she and Hope trek through the remainder of the Vile Peaks, the pressure of keeping Hope safe and dealing with the enemy soldiers take their toll on Lightning and she snaps at him for being unable to keep up with her. The Eidolon Odin appears and attacks Hope, as if to force her to choose between her mission and him. Together they bring the Eidolon under control, and Lightning resolves to help Hope 'toughen up' as they continue on their mission together. 
Snow and Serah's crystal are taken aboard the Cavalry's headquarters, the airship Lindblum, where their leader, Cid Raines, asks Snow to help him find the other l'Cie so they together they could free the people of Cocoon from the fal'Cie rule. While passing through the Gapra Whitewood, Lightning learns about Hope's mother and the boy's belief her death was Snow's fault. Hope reveals he followed Lightning to gain battle experience and become strong enough to face Snow and forms 'Operation Nora', his plan for revenge. Although Lightning tries to convince Hope it was the Sanctum that killed his mother and not Snow, Hope vows to make both Snow and the Sanctum pay for her death. To dissuade Hope from his goal of revenge, Lightning suggests Hope talks with his father in Palumpolum.

After making their way out of the Vile Peaks, Sazh and Vanille travel through the Sunleth Waterscape towards Nautilus. Sazh confesses why he went to the Hanging Edge; his son, Dajh Katzroy, was made a Sanctum l'Cie by the fal'Cie Kujata during the incident at Euride Gorge. Sazh suspected his Focus was to destroy Anima when Dajh sensed the Pulse Vestige in Bodhum and caused the Purge. To save Dajh from becoming a Cie'th, a mindless shambling monster that a l'Cie becomes if they fail their Focus, Sazh boarded the Purge train with Lightning to try and complete Dajh's Focus for him. Unbeknownst to Sazh, Vanille knows more about the Euride incident than she lets on.

\section{Truths Revealed}

Arriving in Palumpolum, Hope leads Lightning underground to slip past the soldiers occupying the city. Lightning realizes she has been running away from reality by making the Sanctum her enemy and she now has Hope following suit. She tells him to end Operation Nora and talk with his dad. Returning to the surface, Lightning and Hope are surrounded by PSICOM troops. They are saved by Snow and Fang and the l'Cie are separated in the chaos, with Lightning and Fang in one group and Snow and Hope in another. Fang reveals she and Vanille are not only Pulse l'Cie but citizens of Gran Pulse, having received their Focus there long ago and entered crystal stasis, but they somehow awoke in Cocoon within the Pulse Vestige several days ago, starting the chain of events that led Cocoon into chaos. Fang tells Lightning she and Vanille were indirectly responsible for Serah becoming a l'Cie, and that someday she will awaken from crystal stasis. 
Elsewhere, Hope confronts Snow about his mother's death, intending on taking his revenge. His plans are foiled when a PSICOM warmech attacks them and Snow saves Hope from further harm by cushioning their fall from the rooftops. Snow apologizes to Hope for what happened to Nora and the two settle their differences. Fang, Lightning, Hope and Snow are reunited and head to the Estheim Residence where Snow recovers from his injuries while Hope informs his father of Nora's fate and repairs his relationship with him.

While the party is busy formulating a plan to deal with the Sanctum, PSICOM officer Yaag Rosch arrives with his troops. Snow tries to make them realize they wish to protect Cocoon and demands the Purge to be stopped, but Yaag claims the lives of Pulse l'Cie are not worth the risk of sparing, and that the Purge is demanded by the people of Cocoon. After a confrontation with an attack shuttle, Snow, Lightning, Hope and Fang are rescued by Rygdea and taken onboard the Lindblum with help from Cid.

Sazh and Vanille arrive at Nautilus where they watch a newsflash regarding the events in Palumpolum and the Pompa Sancta parade, a dramatic re-enactment of the War of Transgression. Tired of running Sazh decides to turn himself for a chance of seeing his son one last time. Vanille protests and is about to reveal the truth about the Euride incident when Jihl Nabaat, PSICOM's supreme commander, arrives with a PSICOM platoon and Dajh. Upon reuniting with Sazh, Dajh turns to crystal and his Focus is revealed to be the capture of Pulse l'Cie. Jihl shows security footage from Euride Gorge and reveals the truth behind the incident: Dajh's transformation into a l'Cie was the result of Vanille and Fang's threat towards Kujata.

Furious, Sazh confronts Vanille, triggering the appearance of his Eidolon, Brynhildr, which he brings under control with Vanille's help. In his grief, Sazh tries to shoot himself but is unable to do so, prompting the PSICOM soldiers to take him and Vanille into custody. They are taken aboard the Palamecia, upon which they will be transported to Eden for live execution. During their imprisonment Vanille reveals her origins to Sazh: she and Fang became l'Cie to fight Cocoon during the War of Transgression, and entered crystal stasis on Pulse. Twelve days before the Purge they awoke in Cocoon but Fang had lost her memory of their previous Focus. Not wanting any more people to get hurt because of them, Vanille lied to also have lost her memory and has been running from her fate ever since. 
Upon learning of Sazh and Vanille's incarceration, Lightning and the rest mount a rescue mission with help from Cid and the Cavalry. They board the Palamecia using a stolen PSICOM shuttle but their ruse is discovered. Sazh and Vanille escape their holding cell, recover their weapons, and fight their way through the ship. The l'Cie are reunited on a forward portion of the Palamecia's exterior, and, using one of PSICOM's militarized wyverns, head towards the bridge. They face Galenth Dysley who kills Jihl and the entire bridge crew. Dismissing the l'Cie's assumption he is one of them, Dysley reveals he is the fal'Cie Barthandelus, the true master of Cocoon.

After suffering defeat at the hands of the l'Cie, Barthandelus reveals the l'Cie's Focus is to become Ragnarok and destroy Orphan, the fal'Cie that powers all the other fal'Cie in Cocoon and holds it afloat over Pulse. Barthandelus claims Serah's Focus was to gather them together to be made l'Cie so they could bring about Cocoon's destruction, a revelation that cripples Snow. Barthandelus departs, leaving behind his familiar Menrva to serve as an airship for them to escape from the now-sinking battlecruiser. The l'Cie make their escape, avoiding pursuit from Yaag Rosch onboard The Proudclad, ending up inside the Fifth Ark hidden underneath Eden. Fang and Vanille recall a legend concerning the purpose of the Arks, armories and training grounds for l'Cie.

The l'Cie's powers are fully awoken and deeper inside the Ark they come face-to-face with Cid Raines, who reveals himself as a Sanctum l'Cie, and that every action of the l'Cie had been orchestrated by Barthandelus. He explains the fal'Cie's desire Cocoon's destruction to summon the Maker, the creator of both fal'Cie and the world. Cid attacks the l'Cie to stop them from destroying Cocoon, but is defeated and turns to crystal despite defying his Focus.

Shaken by the turn of events, the l'Cie reach a dead end. Snow decides to follow Cid's example and forget their Focus and fulfill Serah's final wish of saving Cocoon. While everyone else agrees, Fang turns on them, proclaiming that even though they might wish to save Cocoon she would rather follow their Focus to destroy it than see any of her friends become a Cie'th for defying it. Fang unwittingly summons Bahamut, and brings it under her control with the others' help, reluctantly agreeing to follow with their plan. The l'Cie discover a new path following Bahamut's "taming" and a Pulsian airship at the end, which they use to travel through a portal leading to Gran Pulse. 


\section{Terra Incognita}

The airship is attacked by a wild wyvern in the skies above Pulse, and the l'Cie become stranded in the valley of Vallis Media. The party searches Gran Pulse for days looking for a way to remove their brands but find no traces of human life. Sazh's Chocobo Chick warns the party that Hope's l'Cie brand is advancing and he has fallen unconscious. They bring Hope back to the base camp and Vanille suggests they go to Oerba, her and Fang's hometown. Hope wakes up and tells them he should remain behind but his Eidolon Alexander is summoned and brought under his control. After Hope is given newfound strength, the l'Cie come to believe the true purpose of the Eidolons is to give l'Cie hope instead of freeing them through death.

Discovering a path to the Archylte Steppe, the l'Cie begin their journey to Oerba. Along the way, Vanille claims she became Ragnarok during the War of Transgression and cracked Cocoon's shell as her previous Focus. While traversing the Mah'habara Subterra, Fang bluffs about remembering her past Focus to coax a confession out of Vanille. Fang claims she was the one who became Ragnarok and scarred Cocoon. Vanille tries to deny it but the shock from having her deepest lie exposed causes her Eidolon Hecatoncheir to appear, confirming Fang's suspicions. Vanille and Fang defeat it, after which Vanille resolves to come to terms with her fate and stop running away.

The l'Cie traverse the remainder of the Mah'habara mines and use the fal'Cie Atomos to reach the Sulyya Springs, where Vanille speculates Barthandelus lies to them about Serah's Focus, and that she had overcame her Focus and turned to crystal like Cid had. They reach Taejin's Tower, a crumbling mechanical tower where the fal'Cie Dahaka makes its home. The Menhirrim there help them destroy the errant fal'Cie and reach the top of the tower from where the l'Cie ride a capsule down to the slopes of Oerba. They find the village covered in a blanket of snow-like crystal dust and infested with Cie'th. At the end of a crumbling railway overpass, the l'Cie are shocked to find Serah waiting for them.

Serah implores the l'Cie to become Ragnarok and destroy Orphan, but they refuse to believe her. She abandons her disguise and assumes Barthandelus's human form. The fal'Cie explains the reason Cocoon was created: the fal'Cie, desiring to summon the Maker, need a sacrifice large enough to attract the Maker's attention and that the deaths of Cocoon's inhabitants would cause a large enough disturbance in "the great beyond" for it to happen. The l'Cie engage Barthandelus in battle, determined to prevent this atrocity from being committed. 
After defeating him Barthandelus gloats how the citizens of Cocoon are fighting among themselves now that the resurrected Cid has become the new Primarch. He warns them the Cavalry is mounting an attack to destroy Orphan under the belief it would free Cocoon from the fal'Cie rule, and they have a choice: destroy Orphan themselves or let the people of Cocoon destroy it. He leaves behind another airship and returns to Cocoon to oversee the final stages of his plan. The l'Cie find an ancient record telling the War of Transgression's aftermath: the reason Fang hadn't destroyed Cocoon was because the goddess Etro intervened and turned her and Vanille to crystal before they could. Later, after Vanille and Fang's crystals were placed inside the Pulse Vestige, Barthandelus brought the Vestige into Cocoon so they could finish the job when they awoke. The party decides to return to Cocoon and either save Orphan or die trying. They board the airship and use a portal in Pulse's atmosphere to return to Cocoon.

\section{Eden Under Siege/The Cradle Will Fall}

The l'Cie disrupt an ongoing race in Eden with their Eidolons, causing mass panic among the spectators and the deployment of a full PSICOM battalion along with the resident Guardian Corps unit. Barthandelus uses transgates to warp Pulse creatures and automata from both the surface of Gran Pulse and within the Fifth Ark into the city, causing mass hysteria. The l'Cie fight their way through soldiers and monsters alike while the Cavalry infiltrates the Primarch's office, where Cid, no longer under the thrall of Barthandelus, tells Rygdea his actions will lead Cocoon into ruin. At his request, Rygdea shoots Cid, ending his torment, and leads the Cavalry to confront Orphan at Edenhall, the seat of the Sanctum's power.

The citizens take shelter at Edenhall and at the center of the complex, the l'Cie spot crystal shards floating in the air. An illusion of Barthandelus appears telling them the shards are the souls of the departed, and their presence signals the appearance of the Door of Souls and the Maker's inevitable return, and tells them he has their 'loved ones' captive. The Calvary soldiers and PSICOM troopers in their vicinity turn into Sacrifice Cie'th, the result of Barthandelus branding them without giving them a Focus. They are confronted by Yaag Rosch, who, after being defeated for the second time, helps the l'Cie by ordering his soldiers to evacuate the city rather than search for the l'Cie and detonating the Proudclad's wreckage, sacrificing himself and ensuring the party won't be followed into Orphan's Cradle, an alternate dimension serving as the true command center of Cocoon. 
Inside Orphan's Cradle, the l'Cie discover the remainder of the Calvary soldiers have been converted into Cie'th. Guided by the fal'Cie Eden, they arrive at the Narthex, Orphan's resting place. Barthandelus destroys Serah's and Dajh's crystallized forms and commands the l'Cie to fulfill their destiny by destroying Orphan, thereby cutting the power fueling Cocoon's functions and causing it to crash onto the surface of the lowerworld. The l'Cie see through Barthandelus's illusions, and Barthandelus engages them in battle only to be defeated and sent sinking into a pool of liquid. Menrva dives into the pool allowing Barthandelus to rise up as the protective shell surrounding the dormant fal'Cie Orphan.

The l'Cie fight Barthandelus in Orphan's first form, but fail to destroy him. Barthandelus, growing frustrated, reveals the reason fal'Cie make l'Cie: Each fal'Cie was created by the Maker for a defined purpose, and given finite power to accomplish the task given to them, but humans have infinite potential to be anything they want to be through sheer willpower and determination, an ability beyond the reach of the fal'Cie. For this reason fal'Cie make l'Cie: to partake in the power inherent in humankind.

Orphan tortures Vanille to force Fang to transform into Ragnarok. Seeing no way out of their situation, Fang submits but the others try to stop her. She overpowers them, causing everyone except her and Vanille to turn into Cie'th. Fang is attacked by the shambling remnants of her companions, triggering her transformation into an incomplete version of Ragnarok. Fang's Ragnarok is unable to destroy Orphan; only the outer shield dissipates before Fang reverts to human form. Orphan revives Fang and tortures her to force her to transform into Ragnarok once more, while a helpless Vanille watches her friend suffer. Meanwhile, Lightning, Snow, Sazh, and Hope relive the memories of their journey and find the strength of will to revert, though they believe their Cie'th forms were another fal'Cie illusion. As Vanille prepares to make a stand against Orphan, the others fire magic spells at Orphan and save Fang from the fal'Cie, who sinks into the pool where he is presumably destroyed for good.

After giving themselves the Focus of saving Cocoon rather than destroying it, the party's l'Cie brands burn out. Orphan's true form rises from the pool, and reveals it shares the same desire as Barthandelus to summon the Maker, even if it means its death. Believing that if they can destroy Cocoon, they can also save it, the l'Cie attack Orphan and destroy it. 


\section{The Dawn of a New Era}

With Orphan's demise the rest of Cocoon's fal'Cie shut down as the now-powerless structure descends towards Gran Pulse. Finding themselves back in Eden, Lightning and the others float away and begin to crystallize while Fang and Vanille choose to sacrifice themselves and join hands to summon Ragnarok's true form. Ragnarok creates a column of lava, which engulfs the surface of Cocoon and slows its descent. Ragnarok crystallizes the lava by summoning the crystal dust from the ruins of Oerba, leaving Cocoon supported by a massive crystal pillar entrenched on Pulse's surface. Their Focus fulfilled, Lightning, Hope, Sazh and Snow are crystallized on the surface of Gran Pulse.

Through an unknown force, Lightning and her companions wake up from their crystal sleep. Finding their l'Cie brands gone, the group is reunited with Serah and Dajh who were also revived and are normal humans again. While the Cocoon survivors rally around the remaining military units as they see Gran Pulse for the first time, Hope takes a moment to mourn for Fang and Vanille while Lightning gives Serah her blessing to marry Snow. Within the core of the crystal pillar holding Cocoon above Gran Pulse, the crystallized forms of Vanille and Fang float, still holding hands, their Focus complete.

Fonte

http://finalfantasy.wikia.com/wiki/Final_Fantasy_XIII\#Story

\section{Anexo E: principais termos usados ao longo do Capítulo 4}

Os termos aqui listados referem-se a Final Fantasy XIII. Para maiores detalhes, verificar os links constantes do Anexo B e/ou o resumo constante do Anexo D.

\section{Cocoon}

Espécie de esfera habitável criada séculos antes dos eventos do jogo terem início com o objetivo separar uma parcela da população do mundo conhecido como Pulse. É governada por uma instituição denominada Sanctum e é bastante militarizada.

\section{Pulse}

Mundo inferior temido pelos habitantes de Cocoon. Todo acesso a ele (ou a qualquer informação) é proibido, sob pena de expurgo. 


\section{Fal'Cie}

Ente superior, dotado de poderes especiais e longevidade eterna. Não têm livre-arbítrio e precisa dominar humanos por meio de uma marca na pele para que eles ajam em seu nome. Há Fal'Cies tanto em Cocoon quanto em Pulse.

\section{L'Cie}

Humanos marcados por Fal'Cies tornam-se L'Cies, super-humanos dotados de poderes especiais, grande força e resistência. Caso cumpram a missão determinada pelo Fal'Cie (denominada Focus), tornam-se estátuas de cristal como "recompensa"; caso ignorem ou não consigam realizar a tarefa, tornam-se monstros desprovidos de qualquer sentimento além de rancor (denominados Cie'th).

\section{Palumpolum}

Uma das cidades mais importantes de Cocoon. É a capital comercial. 